\title{
Long-Term Structural Solution for the Mouth of Colorado River Navigation Channel, Texas
}

Nicholas C. Kraus, Lihwa Lin, Ernest R. Smith, Daniel J. Heilman,

April 2008 and Robert C. Thomas

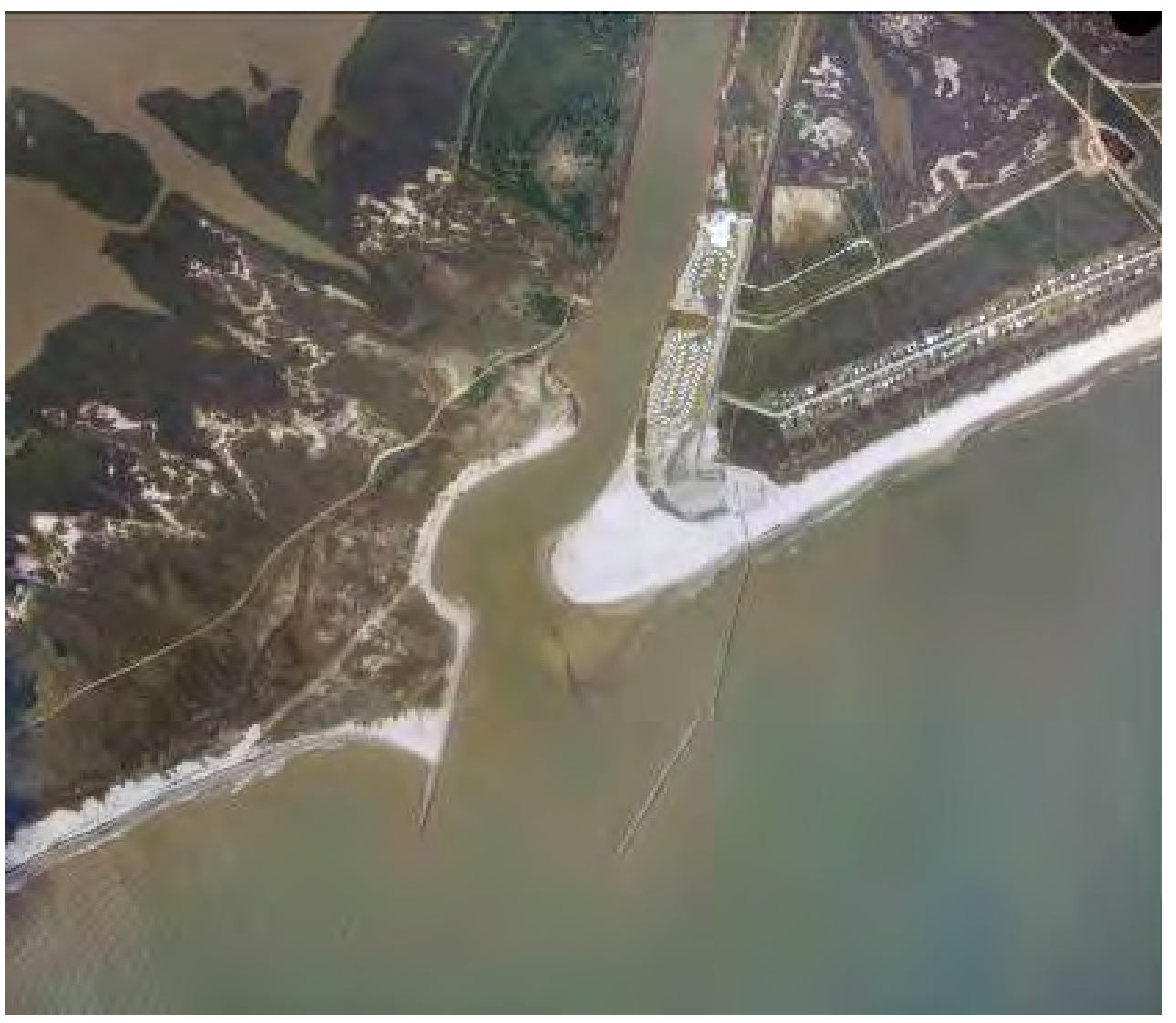

Mouth of Colorado River, 16 May 2006.

(copyright Lanmon Aerial Photography, Inc., Corpus Christi, TX, reproduced with permission) 


\title{
Long-Term Structural Solution for the Mouth of Colorado River Navigation Channel, Texas
}

\author{
Nicholas C. Kraus, Lihwa Lin, and Ernest R. Smith \\ Coastal and Hydraulics Laboratory \\ U.S. Army Engineer Research and Development Center \\ 3909 Halls Ferry Road \\ Vicksburg, MS 39180-6199 \\ Daniel J. Heilman and Robert C. Thomas \\ $H D R \mid$ Shiner Moseley and Associates, Inc. \\ 555 N. Carancahua, Suite 1650 \\ Corpus Christi, TX 78478
}

Final report

Approved for public release; distribution is unlimited.

Prepared for U.S. Army Engineer District, Galveston

2000 Fort Point Road

Galveston, TX 77550 


\begin{abstract}
This report describes a study performed for the U.S. Army Engineer District, Galveston, to develop a structural solution involving modified or new jetties in support of a reliable shallow-draft channel at the Mouth of the Colorado River (MCR), Texas. The site has experienced excessive sediment shoaling that has denied full project features to navigation channel users. The study took a multidisciplinary approach involving field measurements, shoreline analysis, numerical modeling of shoreline change and longshore sand transport, numerical modeling of inlet processes, and preliminary design of a new east jetty. The study concluded that the MCR was not performing as intended because (1) the Colorado River was diverted to Matagorda Bay in 1992 as part of an environmental restoration project, thus depriving the inlet of the river's discharge of water and associated scouring action; (2) the weir jetty system constructed over 1988-1990 was too wide and the weir section too long; and (3) the sediment impoundment basin associated with the weir is dangerous for people wade fishing and allows sediment to be bypassed during times of high water.
\end{abstract}

The solution obtained is to construct a new east jetty parallel to and $500 \mathrm{ft}$ $(152 \mathrm{~m})$ from the west jetty. It is recommended that past bypassing practice be continued through dredging of the impoundment fillet expected to form on the beach adjacent to the new east jetty and placing that material on the west beach. The preliminary jetty design incorporates experience with jetties of similar size inlets along the Texas coast.

DISCLAIMER: The contents of this report are not to be used for advertising, publication, or promotional purposes. Citation of trade names does not constitute an official endorsement or approval of the use of such commercial products. All product names and trademarks cited are the property of their respective owners. The findings of this report are not to be construed as an official Department of the Army position unless so designated by other authorized documents. 


\section{Contents}

Contents. iil

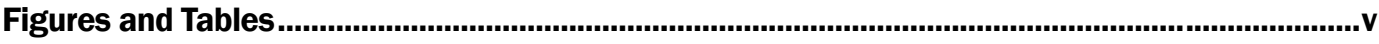

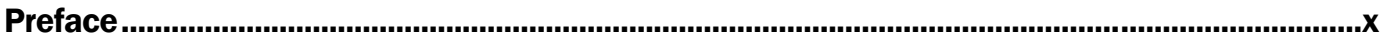

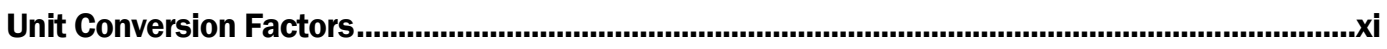

1 Introduction...................................................................................................................... 1

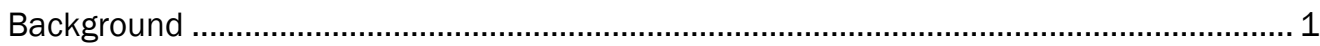

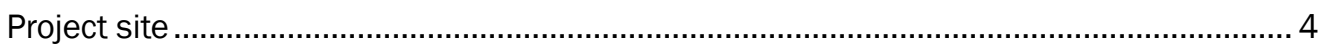

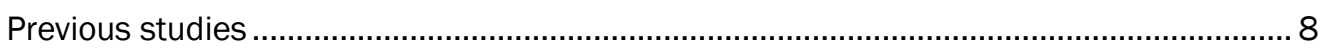

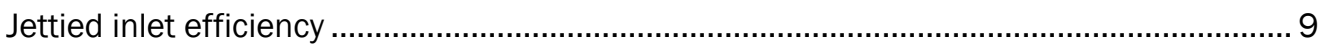

Morphology change ................................................................................................... 10

Ebb-shoal development ........................................................................................ 13

Synthesis of findings and development of alternatives .............................................. 13

Initial conclusions and proposed plan of action from previous studies............................. 16

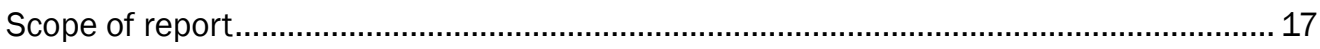

2 Shoreline Change and Longshore Sand Transport Rate........................................................19

Background on littoral processes................................................................................... 19

Observed shoreline change ......................................................................................... 19

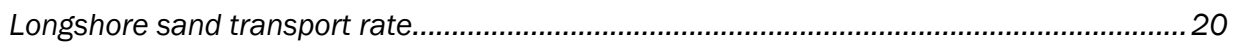

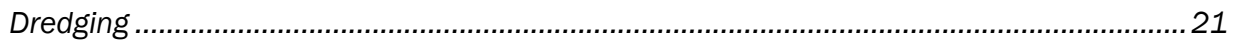

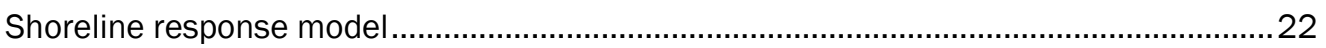

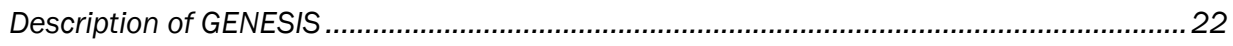

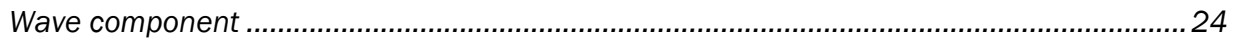

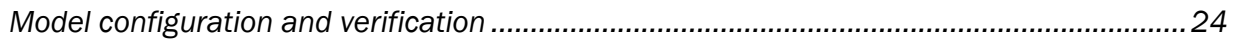

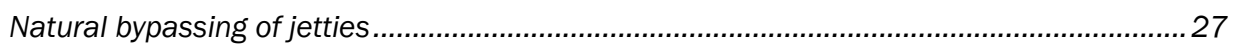

Shoreline response without mechanical bypassing ............................................................ 29

Shoreline response with mechanical bypassing ................................................................. 30

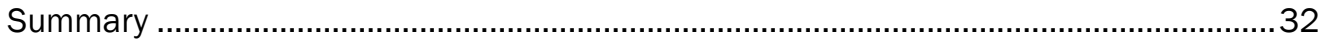

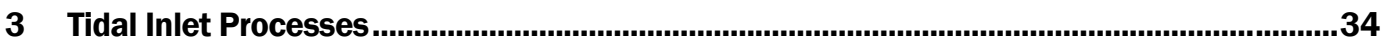

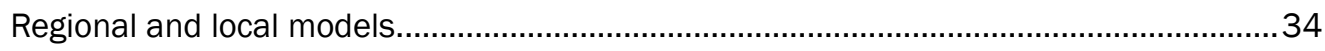

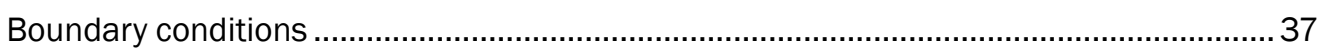

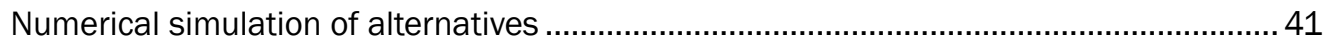

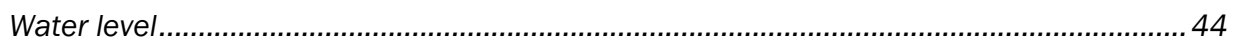

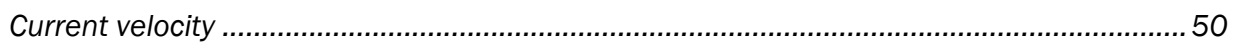

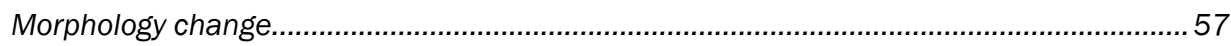

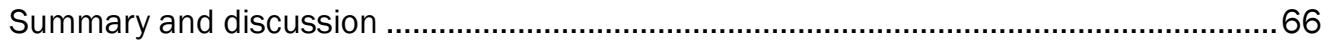


4 Preliminary Jetty Design ..................................................................................................69

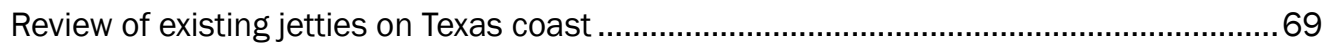

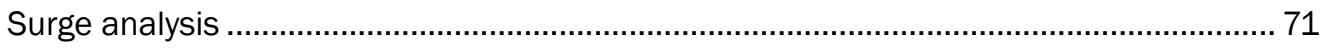

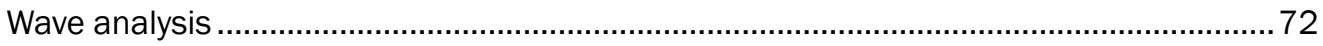

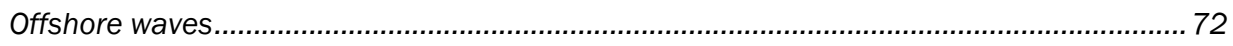

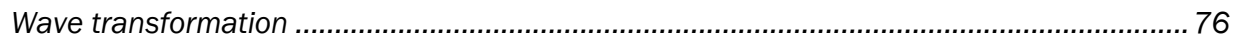

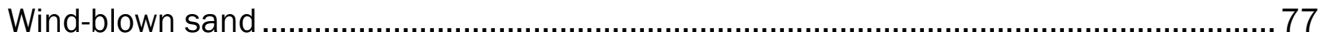

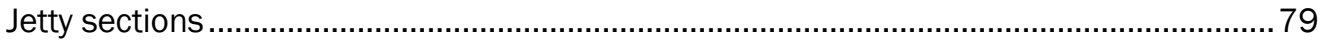

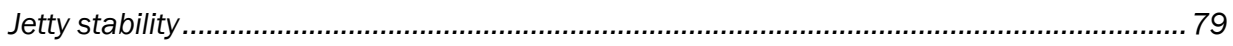

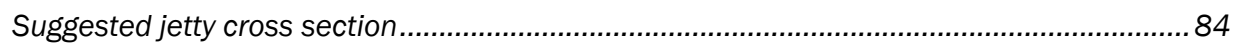

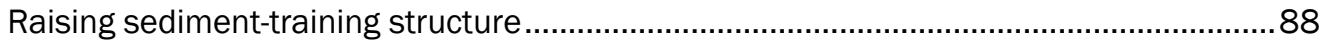

Preliminary opinion of probable construction cost........................................................ 88

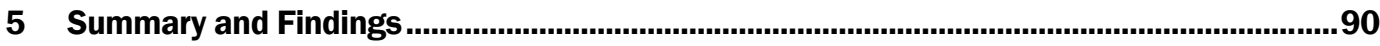

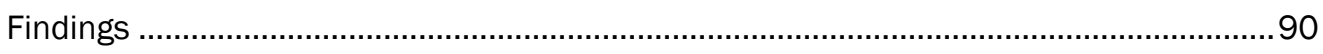

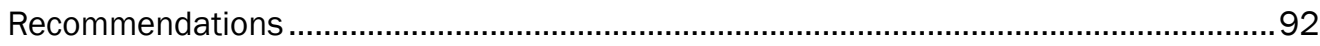

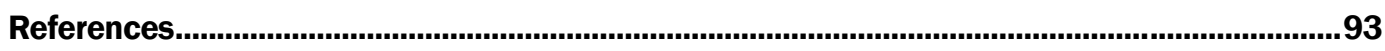

Appendix A: Calibration of Regional Circulation Model........................................................97

Appendix B: Summary of Figures for Calculated Current Velocities at sta 1, sta 2,

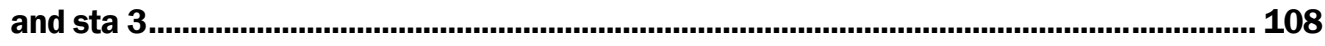

Appendix C: Aerial Photographs, Mouth of Colorado River ........................................................111

Appendix D: Subsurface Investigation ............................................................................ 139

\section{Report Documentation Page}




\section{Figures and Tables}

\section{Figures}

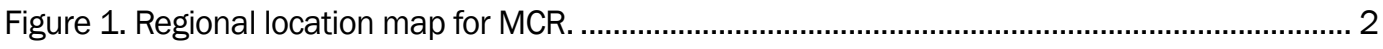

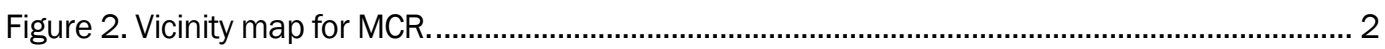

Figure 3. Example alternatives considered in GDM..................................................................... 6

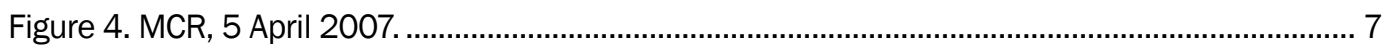

Figure 5. MCR, with navigation project features indicated............................................................... 7

Figure 6. Morphologic behavior of MCR ..................................................................................... 10

Figure 7. Example channel cross section before and after dredging............................................. 12

Figure 8. Elevation change in impoundment basin and navigation channel. .................................. 12

Figure 9. Major sediment pathways at MCR. .............................................................................. 14

Figure 10. Sediment-training structure shortly after construction. ................................................ 15

Figure 11. Incremental implementation of actions. ................................................................ 17

Figure 12. Shoreline change interpreted by GIS analysis from rectified aerial photographs. .........20

Figure 13. Dredging rates at MCR from May 1990 to present.......................................................2

Figure 14. East Beach longshore transport rates as function of distance from east jetty................ 26

Figure 15. West Beach longshore transport rates as function of distance from west jetty.............. 27

Figure 16. Volume of sand by year bypassing east and west jetties..............................................28

Figure 17. Predicted shoreline change, east beach........................................................................2

Figure 18. Predicted shoreline change, west beach.................................................................... 30

Figure 19. Shoreline position after 10 years of WIS waves from 1980 and 1989 with proposed jetty design, with and without sediment bypassing from up-drift to down-drift beaches.

Figure 20. Shoreline position after 10 years of WIS waves from 1990 to 1999 with proposed jetty design, with and without sediment bypassing from up-drift to down-drift beaches.

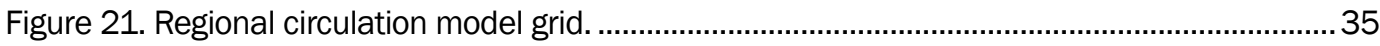

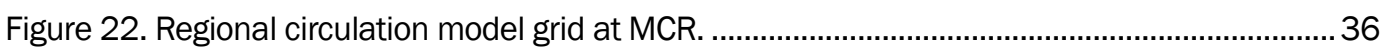

Figure 23. CMS numerical grid domain. ................................................................................. 37

Figure 24. Discharges at Colorado River and San Bernard River, 1999. .......................................38

Figure 25. Time series of measured wind wave data at Buoy 42019 and by transformation to wave model offshore boundary, MCR. ………….............................................. 40

Figure 26. New east jetty and 150-ft-wide channel...................................................................... 41

Figure 27. New east jetty and 200-ft-wide channel. ................................................................... 42

Figure 28. Water level data from Bob Hall Pier and Galveston Pleasure Pier.................................. 43

Figure 29. Calculated wave field under incident wave of 1-m significant height and 7-sec spectral period from southeast. ............................................................................................. 44

Figure 30. Calculated water levels for existing and new east jetty conditions................................. 45 
Figure 31. Calculated water levels for existing condition and opening SW Cut................................46

Figure 32. Calculated water levels for existing and opening Parkers Cut........................................ 47

Figure 33. Calculated water levels for Alt 0 with 150 - and 200-ft-wide channels............................ 48

Figure 34. Calculated water levels for opening SW Cut................................................................ 49

Figure 35. Calculated water levels for opening Parkers Cut. .......................................................50

Figure 36. Calculated velocity for new east jetty with 150-ft- and 200-ft- wide channels. ............... 51

Figure 37. Calculated velocity for opening SW Cut....................................................................5

Figure 38. Calculated velocities for opening Parkers Cut.............................................................53

Figure 39. Calculated maximum flood current for new east jetty.................................................... 54

Figure 40. Calculated maximum ebb current for new east jetty....................................................... 55

Figure 41. Calculated maximum flood current for opening SW Corner Cut.......................................55

Figure 42. Calculated maximum ebb current for opening SW Corner Cut........................................56

Figure 43. Calculated maximum flood current for opening Parkers Cut. .........................................56

Figure 44. Calculated maximum ebb current for opening Parkers Cut. ........................................... 57

Figure 45. A winter-month morphology change and average transport rate for Alt 0. .......................58

Figure 46. A summer-month morphology change and average transport rate for Alt 0. ..................58

Figure 47. A winter-month morphology change and average transport rate for Alt 1......................59

Figure 48. A summer-month morphology change and average transport rate for Alt 1. ..................60

Figure 49. A winter-month morphology change and average transport rate for Alt 3......................60

Figure 50. A summer-month morphology change and average transport rate for Alt 3. ..................61

Figure 51. A winter-month morphology change for Alt 5........................................................... 61

Figure 52. A winter-month morphology difference between Alts 1 and 3. ......................................63

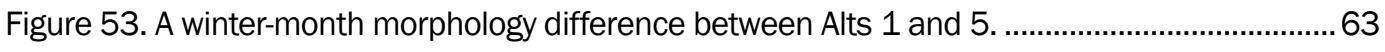

Figure 54. A winter-month morphology difference between Alts 1 and 2. ......................................64

Figure 55. A winter-month morphology difference between Alts 3 and 4. .................................... 64

Figure 56. A winter-month morphology difference between Alts 5 and 6 . .......................................6 65

Figure 57. A winter-month morphology change for Alt 7. .............................................................. 65

Figure 58. Areas A, B, and C for sediment volume change calculations. .........................................67

Figure 59. 2007 crest elevation of MCR jetties. …………………………………………........ 71

Figure 60. Maximum significant wave height during identified storms.......................................... 73

Figure 61. Peak period during identified storms........................................................................... 74

Figure 62. Mean wave direction during identified storms................................................................ 74

Figure 63. Extreme wave height analysis of data from WIS sta 54.............................................. 75

Figure 64. Extreme wave height analysis of data from WIS sta 57. ................................................. 75

Figure $65 . H_{s}$ and $H_{1 \%}$ at jetty toe as function of storm surge. ..................................................... 77

Figure 66. Aerial photograph of Fish Pass, TX............................................................................. 78

Figure 67. Photograph of buried sediment-training structure...................................................... 78

Figure 68. Proposed preliminary jetty cross section layout........................................................... 79

Figure 69. Armor stone weight calculated with Hudson equation.................................................... 81

Figure 70. Armor stone weight calculated with van der Meer equations. .......................................82 
Figure 71. Minimum armor stone weight using calculated reductions for inundation of structure.

Figure 72. Plan view of location of proposed new east jetty, MCR ……........................................ 87

Figure 73. Cross-sectional view of proposed new east jetty, MCR. ………………........................ 87

Figure A1. Location of water level gauges and current meters. ....................................................98

Figure A2. Surface winds, water levels, and river discharges for model input boundary conditions.

Figure A3. Measured and calculated water levels at Port Lavaca, Port O'Connor, Rawlings, and at East Matagorda Bay, Old Gulf Cut.. 100

Figure A4. Measured and calculated water levels at Channel Markers 5, 9, and 15, and at Holiday Harbor, GIWW.

Figure A5. Measured and calculated currents at Channel Markers 5, 6, and 9. 103

Figure A6. Measured and calculated currents at Channel Marker 15, Holiday Harbor,

Figure A7. Linear regression of flow rates and velocity data........................................................106

Figure A8. Calculated discharge and calibrated flow rate............................................................ 107

Figure B1. Calculated velocity for existing condition and new east jetty........................................108

Figure B2. Calculated velocity for existing condition and opening the SW Corner Cut with

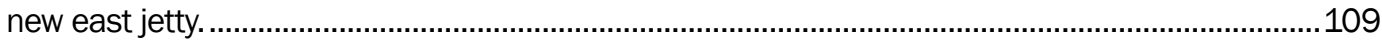

Figure B3. Calculated velocity for existing condition and opening Parkers Cut. .............................110

Figure C1. File 30-Matagorda-A.jpg, Matagorda Bay, 1930s.............................................................111

Figure C2. File 30-Matagorda-B.jpg, Matagorda Bay, Mouth of Colorado River 1930s..................112

Figure C3. File 30-Matagorda-C.jpg, Matagorda Bay, 1930s.....................................................112

Figure C4. File 30-Matagorda-E.jpg, Mouth of Colorado River, 1930s..........................................113

Figure C5. File 43-10-16-MOC-A.tif, Mouth of Colorado River, East Matagorda Bay, 16 October 1943. 113

Figure C6. File 43-10-16-MOC-B.tif, Mouth of Colorado River, 16 October 1943. 114

Figure C7. File 43-10-16-MOC-C.tif, Mouth of Colorado River, East Matagorda Bay, 16 October 1943.

Figure C8. File 53-2-8-MOC.tif, Mouth of Colorado River, 8 February 1953.................................115

Figure C9. File 54-1-1-MOC.tif, Mouth of Colorado River, 1 January 1954...................................115

Figure C10. File 54_CR.tif, Mouth of Colorado River, 1954s.........................................................116

Figure C11. File 58-12-11-MOC.tif, Mouth of Colorado River, 12 December 1958.........................116

Figure C12. File 65-10-22-MOC.tif, Mouth of Colorado River, 22 October 1965. .......................... 117

Figure C13. File 67-6-26-MOC.tif, Mouth of Colorado River, 26 June 1967.................................... 117

Figure C14. File 74_11_20_MOC.tif, Mouth of Colorado River, 20 November 1974.....................118

Figure C15. File 78_CR.tif, Mouth of Colorado River, 1978.......................................................119

Figure C16. File 82-MOC.tif, Mouth of Colorado River, 1982 .......................................................119

Figure C17. File 84_2_29_MOC.tif, Mouth of Colorado River, 29 February 1984........................120

Figure C18. File 85_9_28_MOC.tif, Mouth of Colorado River, 28 September 1985......................120

Figure C19. File 86_10_17_MOC.tif, Mouth of Colorado River, 17 October 1986..........................121

Figure C20. File 90-10B-MOC.jpg, Mouth of Colorado River, October 1990..................................121 
Figure C21. File 90-10C-MOC.jpg, Mouth of Colorado River, October 1990.................................122

Figure C22. File 90-10D-MOC.jpg, Mouth of Colorado River, October 1990..................................122

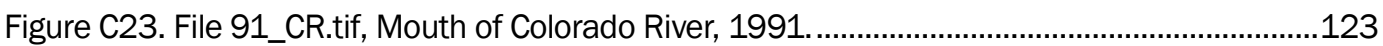

Figure C24. File 91-2-15-MOC.tif, Mouth of Colorado River, 15 February 1991.............................123

Figure C25. File 96-7-MOC.tif, Colorado River and GIWW Intersection, July 1996. ........................124

Figure C26. File 00-1-17-MOC.jpg, Mouth of Colorado River, 17 January 2000. ...........................124

Figure C27. File 00-7-19-MOC.jpg, Mouth of Colorado River, 19 July 2000...................................125

Figure C28. File 01-1-5-MOC.jpg, Mouth of Colorado River, 5 January 2001.............................125

Figure C29. File 01-5-2-MOC.jpg, Mouth of Colorado River, 2 May 2001. .....................................126

Figure C30. File 01-7-8-MOC.jpg, Mouth of Colorado River, 8 July 2001......................................126

Figure C31. File 01-9-26-MOC.jpg, Mouth of Colorado River, 26 September 2001.......................127

Figure C32. File 01-12-19-MOC-A.jpg, Mouth of Colorado River, 19 December 2001...................127

Figure C33. File 01-12-19-MOC-B.jpg, Mouth of Colorado River, 19 December 2001..................128

Figure C34. File 02-8-2-MOC.jpg, Mouth of Colorado River, 2 August 2002. ................................128

Figure C35. File 02-9-11-MOC.jpg, Mouth of Colorado River, 11 September 2002. ......................129

Figure C36. File 02-10-16-MOC.jpg, Mouth of Colorado River, 16 October 2002..........................129

Figure C37. File 03-4-16-MOC.jpg, Mouth of Colorado River, 16 April 2003..................................130

Figure C38. File 03-5-30-MOC-A.jpg, Mouth of Colorado River, 30 May 2003.............................130

Figure C39. File 03-5-30-MOC-B.jpg, Mouth of Colorado River, 30 May 2003...............................131

Figure C40. File 03-8-6-MOC-A.jpg, Mouth of Colorado River, 6 August 2003...............................131

Figure C41. File 03-8-6-MOC-B.jpg, Mouth of Colorado River, 6 August 2003. ..............................132

Figure C42. File 03-9-8-MOC-A.jpg, Mouth of Colorado River, 8 September 2003........................132

Figure C43. File 03-9-8-MOC-B.jpg, Mouth of Colorado River, 8 September 2003..........................133

Figure C44. File 03-12-18-MOC-A.jpg, Mouth of Colorado River, 18 December 2003...................133

Figure C45. File 03-12-18-MOC-B.jpg, Mouth of Colorado River, 18 December 2003. .................134

Figure C46. File 04-4-14-MOC.jpg, Mouth of Colorado River, 14 April 2004................................134

Figure C47. File 04-8-13-MOC-A.jpg, Mouth of Colorado River, 13 August 2004............................135

Figure C48. File 04-8-13-MOC-B.jpg, Mouth of Colorado River, 13 August 2004...........................135

Figure C49. File 06-7-19-MOC.jpg, Mouth of Colorado River, 19 July 2006.................................136

Figure C50. File 06-12-01-MOC-A.jpg, Mouth of Colorado River, 1 December 2006....................136

Figure C51. File06-12-01-MOC-B.jpg, Mouth of Colorado River, 1 December 2006. .....................137

Figure C52. File 07-04-05-MOC-A.jpg, Mouth of Colorado River, 5 April 2007. ..............................137

Figure C53. File 07-04-05-MOC-B.jpg, Mouth of Colorado River, 5 April 2007. ...............................138

\section{Tables}

Table 1. Approximate geometry of five Texas Gulf Coast entrances. .............................................. 9

Table 2. Alternatives that passed screening....................................................................................... 15

Table 3. Incremental approach to improve channel reliability at MCR. ........................................... 16

Table 4. Incremental shoreline change rates. ....................................................................................2 20 
Table 5. Variability in annual potential longshore sand transport rates on east beach calculated from 20-year WIS wave hindcast.

Table 6. Variability in annual potential longshore sand transport rates on east beach calculated from 20-year WIS wave hindcast. 25

Table 7. NDBC Buoy 42019 information. 39

Table 8. Buoy 42019 wave statistics, 1990-1999. . 39

Table 9. Description of alternatives. 42

Table 10. Estimated sediment volume change. 66

Table 11. Selected properties of existing jetties on Texas coast. 70

Table 12. Predicted storm surge elevations 72

Table 13. Measured surge elevations of selected storms. 72

Table 14. 50-year return period wave conditions at WIS sta 54 and $57 .$. 75

Table 15. Summary of proposed cross-section details. 79

Table 16. Preliminary opinion of probable construction cost.. 89

Table A1. Location of gauges. 98

Table A2. Water surface elevation bias, RMS error, and percent error, 2 January to 8 February 2002.

Table A3. Velocity bias, RMS errors, and averaged maximum flood and ebb currents, 2 January to 8 February 2002. 105

Table A4. Flow rate bias and averaged maximum flood and ebb discharges, 2 January to 8 February 2002. 


\section{Preface}

The study described in this report was performed for the U.S. Army Engineer District, Galveston (SWG), to develop a structural solution involving modified or new jetties in support of a reliable shallow-draft channel at the Mouth of Colorado River, Texas. The coastal processes, tidal inlet processes, and functional design portion of this study was conducted by staff of the U.S. Army Engineer Research and Development Center (ERDC), Coastal and Hydraulics Laboratory (CHL). The preliminary structure design portion of the study was conducted by staff from HDR|Shiner Moseley and Associates, Inc. (SMA), under contract with ERDC. The SWG provided review and oversight of study elements. This study was authorized by SWG in mid-October 2006, and a draft version of this report was submitted on 16 J anuary 2007.

This report was prepared by Dr. Nicholas C. Kraus, Senior Scientist Group, CHL, who was responsible for overall technical direction for the study; Dr. Lihwa Lin, Coastal Engineering Branch, CHL; Dr. Ernest R. Smith, Coastal Processes Branch, CHL; and Daniel J . Heilman and Robert C. Thomas, SMA. Successful completion of the study was facilitated by Ronnie G. Barcak, Operations Division, SWG, and by the SWG Project Delivery Team led by George E. Alcala, Planning Division. Work at CHL was performed under the administrative supervision of Thomas W. Richardson, Director, CHL, and Dr. William D. Martin, Deputy Director, CHL.

COL Richard B. J enkins was Commander and Executive Director of ERDC. Dr. J ames R. Houston was Director. 


\section{Unit Conversion Factors}

\begin{tabular}{|l|c|l|}
\hline Multiply & By & To Obtain \\
\hline cubic yards & 0.7645549 & cubic meters \\
\hline feet & 0.3048 & meters \\
\hline miles (U.S. statute) & $1,609.347$ & meters \\
\hline pounds (mass) per cubic foot & 16.01846 & kilograms per cubic meter \\
\hline tons (2,000 pounds, mass) & 907.1847 & kilograms \\
\hline square miles & $2.589998 \mathrm{E}+06$ & square meters \\
\hline
\end{tabular}




\section{Introduction}

This chapter introduces the study area, reviews the history of the Mouth of Colorado River (MCR) Federal navigation project, and compiles central findings of previous studies. The chapter ends with an overview of content of this report.

In fiscal year (FY) 2006, the U.S. Army Engineer District, Galveston (hereafter, the Galveston District), received funds under the FY06 Supplemental Bill passed by the U.S. Congress to restore conditions at the MCR prior to damage from the year 2005 hurricane season that included Hurricanes Rita and Katrina. In lieu of frequent dredging, the Port of Bay City Authority, TX, as a non-Federal sponsor requested the Galveston District to investigate a long-term solution to the excessive sediment shoaling and the dredging required to maintain project channel depth. In J anuary 2007, staff from the U.S. Army Engineer Research and Development Center (ERDC), Coastal and Hydraulics Laboratory (CHL), presented results of model studies that identified and recommended a new 1,600-ft east jetty aligned parallel to the existing west jetty and without a weir. With FY06 Supplemental funds, the SWG is completing the plan and specifications, and obtaining the necessary environmental approvals for construction of the east jetty. This report documents major engineering technical tasks performed in support of the Galveston District study effort.

It is anticipated that FY08 funds will be requested for construction of the east jetty (estimated \$18 million) and dredging of the Colorado River Navigation Channel (CRNC) at the MCR (estimated \$5 million). With the construction of a 1,600-ft east jetty to be completed within 6 months, the project is expected to perform as originally intended in supporting reliable navigation and requiring less frequent dredging.

\section{Background}

The Galveston District has responsibility for maintaining the MCR, a Federally authorized shallow-draft navigation channel located south of Bay City and Matagorda, Matagorda County, TX (Figures 1 and 2). The MCR was formerly the terminus of the Colorado River; however, following diversion of the river into Matagorda Bay in 1992, it now only connects the CRNC and Gulf Intracoastal Waterway (GIWW) to the Gulf of Mexico. 


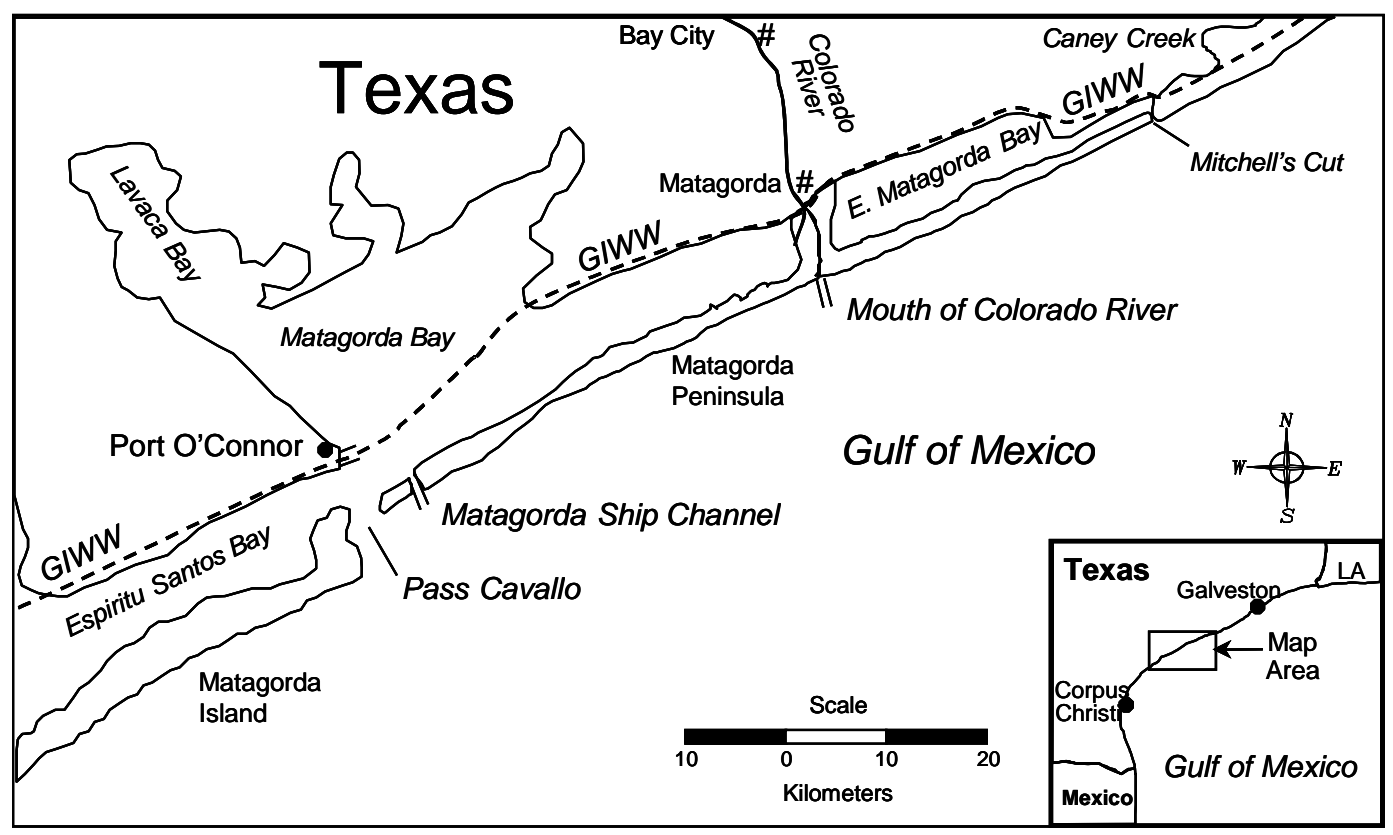

Figure 1. Regional location map for MCR.

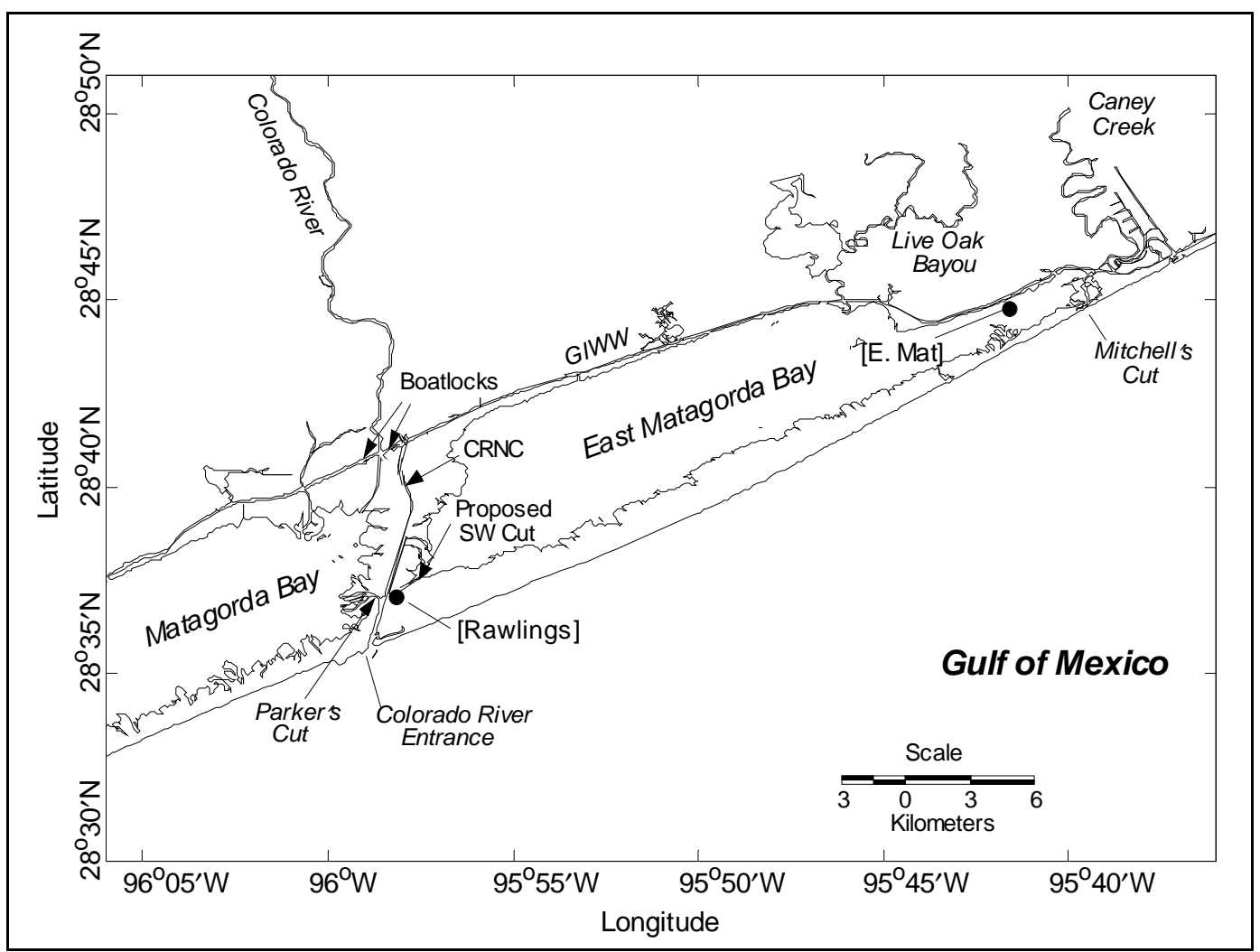

Figure 2. Vicinity map for MCR. 
The Federal project possesses the features of an entrance channel $15 \mathrm{ft}$ deep mean low tide ${ }^{1}$ (MLT) and $200 \mathrm{ft}$ wide at the bottom with two jetties to protect the entrance, a 6.5-mile-long CRNC that is $12 \mathrm{ft}$ deep and $100 \mathrm{ft}$ wide at the bottom, a harbor and turning basin adjacent to the GIWW, and two recreational areas.

In the past, the lower portion of the CRNC was intersected by an inlet connecting it to Matagorda Bay called Parkers Cut or Tiger Island Cut. This pass may trace back to one of the original natural tributaries that formed with delta growth across Matagorda Bay (see photographs in Appendix C). It was dredged in the 1950s to allow shallow-draft access to the Gulf of Mexico from Matagorda Bay and closed in 1992 as part of the environmental plan to divert the Colorado River to the northeast corner of Matagorda Bay (U.S. Army Corps of Engineers (USACE) 1981). Lin et al. (2001) demonstrated through numerical simulation that opening of Parkers Cut would create a flood bias of flow at the MCR, promoting transport of sand into the entrance possibly as far as Parkers Cut, as documented by the Galveston District 1973-1974 surveys reported in the project General Design Memorandum (GDM) (USACE 1977). The flood bias is caused by the difference in phase of the tidal signal at the MCR as compared to the tide in crossing the shallow Matagorda Bay to reach Parkers Cut.

Similarly, Matagorda County is considering opening of what is called the SW Corner Cut or SW Cut that would connect East Matagorda Bay to the lower end of CRNC at a location known as "Rawlings," where a tide gauge was located for several years. The SW Corner Cut would tend to cause the MCR to be ebb biased, a favorable situation for promoting transport of sediment out of the entrance channel (Kraus and Militello 1996, 1999).

Inclusion of cuts or dredged passes under consideration by local interests and the existing inlets in the complex interconnecting bay system makes this a multiple-inlet problem with influence of several rivers and six inlets opening into the Gulf of Mexico or to the CRNC (Mitchells Cut, MCR, Parkers Cut, SW Corner Cut, Matagorda Ship Channel, and Pass Cavallo). Accurate calculation of the tidal and wind-generated flow therefore requires a regional approach in establishing boundary forcing conditions

\footnotetext{
1 MLT is a navigation datum defined by the Galveston District owing to the strong wind and large seasonal variations in water level in the Gulf of Mexico that can change water level on the Texas coastal and inland coastal waters. It lies below the astronomical tide datum of mean lower low water (Kraus et al. 1997).
} 
for driving a numerical model of the acting hydrodynamics. The tidal current at the mouth of the CRNC is weak but ebb biased in its present condition. Wind-induced currents play a substantial role at the shallow bays and channels along the Texas coast (Kraus and Militello 1996, 1999) and must be represented in hydrodynamic modeling. Diversion of the Colorado River into Matagorda Bay in 1992 greatly reduced the discharge into the Gulf of Mexico (the effective ebb tidal prism), weakening the scouring action of the channel current.

\section{Project site}

The physical situation presently encountered at the MCR developed in the 1920s, when a large log raft extending about 46 river miles below Bay City, TX, was cleared. Information on this logjam is contained in an M.S. thesis of Wadsworth (1941), a Bay City native (see also Wadsworth (1966) for a summary). The logjam had evidently developed over hundreds of years. Prior to that time, the Colorado River had flowed variously into Matagorda Bay, joined with Caney Creek, and for some period merged with the Brazos River to the east.

A pilot channel was dredged through the log raft from March 1926 to 1930. River floods in 1929, 1935, and 1936 transported great volumes of sediment and logs into the bay to form a delta that crossed the bay to Matagorda Peninsula. In 1934, to prevent continued flooding of Bay City, the Matagorda and Wharton County Conservation and Reclamation Districts dredged a new course of the river through the delta, emptying the river directly into the Gulf of Mexico. The local interests placed dredged material on both sides of the channel to confine the weak flows of the river within the channel (Ralston 1987). Growth of the Colorado River delta and creation of the flood discharge channel (now the CRNC) divided the bay into two water bodies, Matagorda Bay and East Matagorda Bay. Photographs compiled in Appendix C show the area in the 1930s and 1940s. The Galveston District became involved because of sediment shoaling in the GIWW (Wadsworth 1941). Involvement continued in controlling vessel traffic at the Colorado River and GIWW intersection, in response to environmental interests in diverting the Colorado River directly to Matagorda Bay, and in creating a more reliable entrance channel that would reduce flooding and support shallow-draft navigation (USACE 1977, 1981). 
From about 1940 until 1992 the Colorado River discharged water and sediment into the Gulf of Mexico. Two rubble stone jetties were constructed between 1988 and 1990 to protect the entrance. The east jetty has a 1,000-ft-long weir section on its landward side and an impoundment basin located to the west. In J uly 1992, as part of an environmental enhancement, the river was diverted into Matagorda Bay, eliminating the river discharge as a mechanism for removing littoral sediment from the MCR entrance. Shoaling of the entrance was two or three times greater than anticipated, bringing into question the effectiveness of the weir, impoundment basin, and jetty design.

The MCR project was authorized in Section 101 of the Rivers and Harbors Act of 1968 as a tributary channel to the GIWW (USACE 1977). In this era, the USACE was examining weir jetty designs as a means of protecting coastal inlet entrance channels and for minimizing maintenance costs by dredging from a protected area. A weir allows economical placement of dredged material on the down-drift beach (Parker 1979; Weggel 1981; Seabergh 1983). However, relatively few weir jetties have been built (approximately 12), and their performance record has been mixed (Seabergh and Thomas 2002).

Examples of alternative jetty designs considered by the Galveston District for the MCR (USACE 1977) are shown in Figure 3. The alternative in the upper panel features two parallel jetties, similar to the plan proposed in this report; the middle panel is a weir jetty system; and the lower panel is a relatively novel detached breakwater design as constructed at Ventura Harbor, CA.

The jetties at the MCR are configured as arrowhead type (Figure 4), with the east jetty having a landward 1,000-ft-long weir and an impoundment basin on its west side that has been dredged to $30 \mathrm{ft}$ (Figure 5). The east and west jetties are spaced approximately 1,350 ft apart at their gulfward ends. Full authorized channel dimensions were last available to users in 2001. The spit in the recent photograph (Figure 4) is tending to be oriented offshore, causing bifurcation of the entrance channel as occurred prior to construction of the jetties (Figures C15 and C17 of Appendix C). 


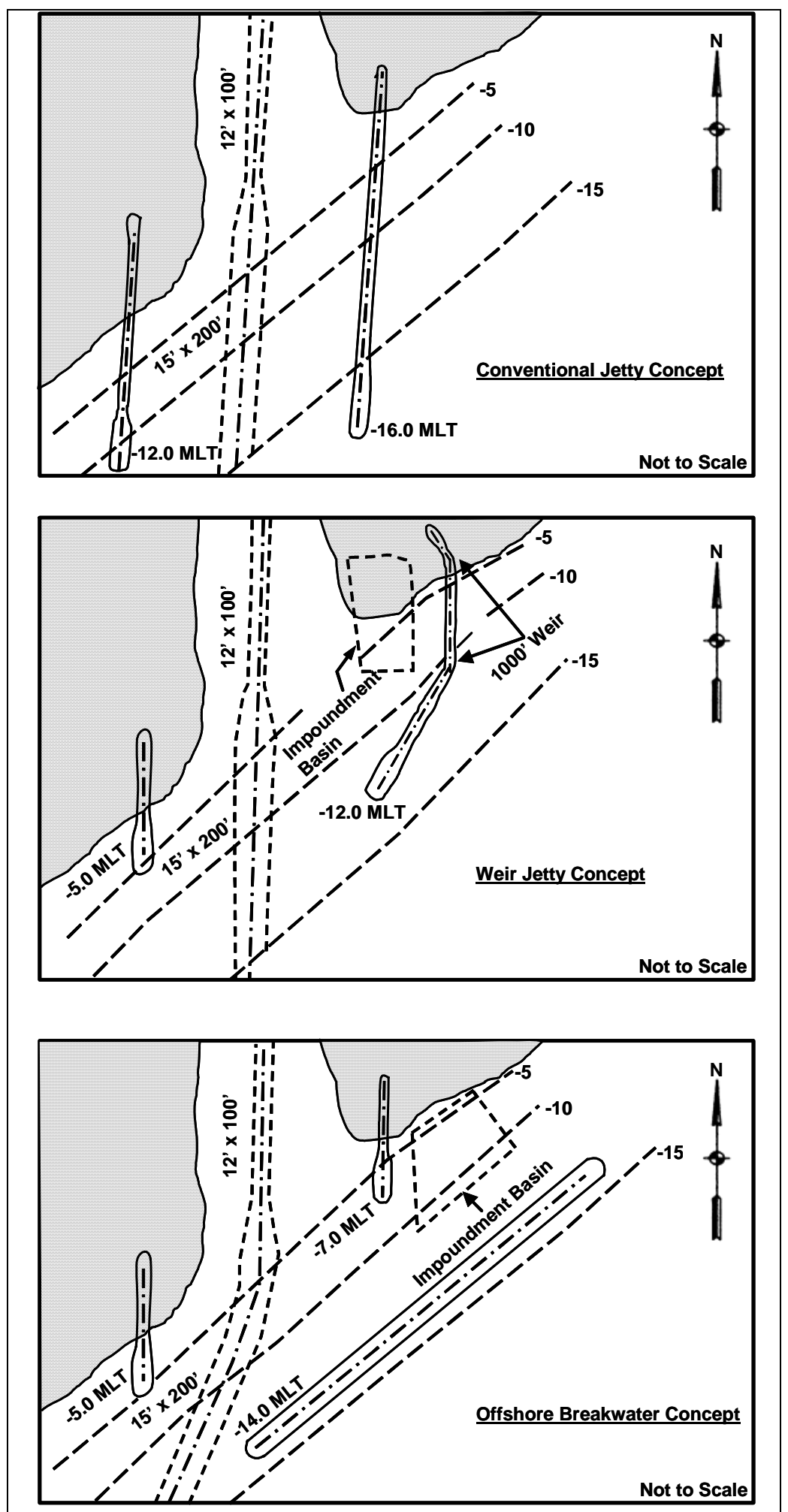

Figure 3. Example alternatives considered in GDM (USACE 1977). 


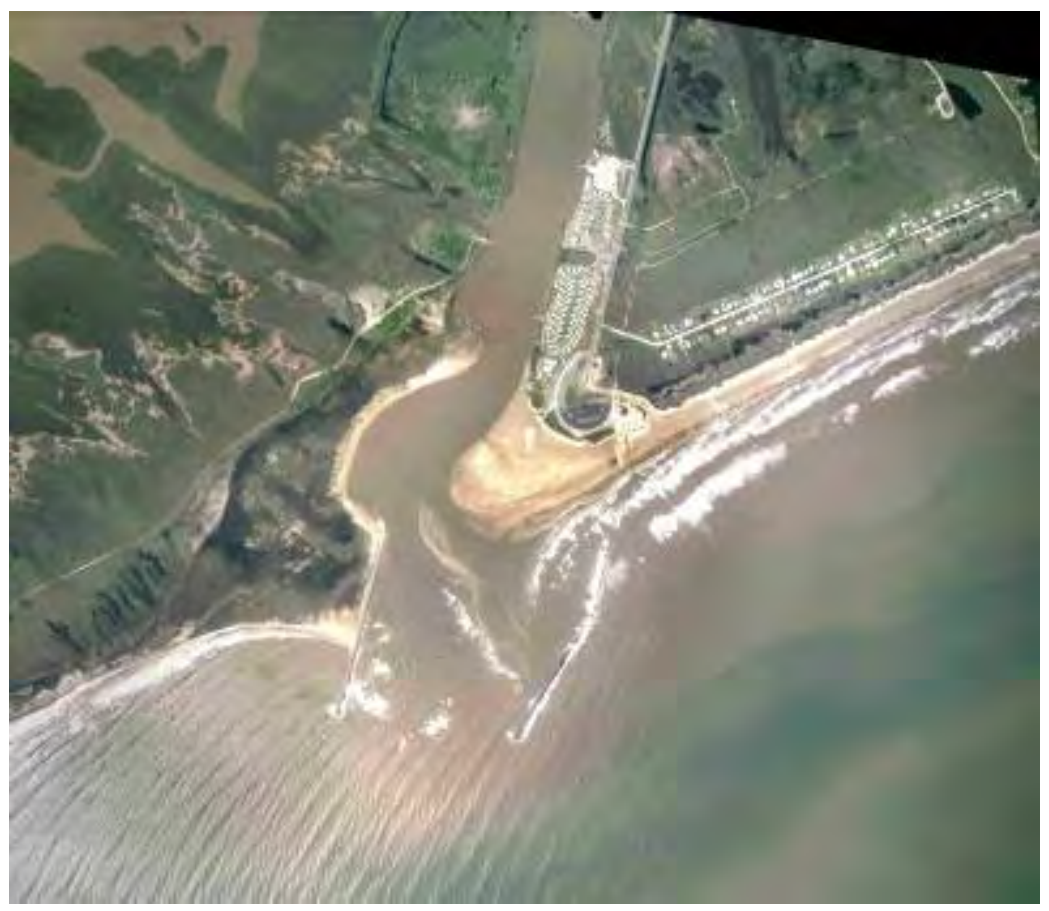

Figure 4. MCR, 5 April 2007 (Lanmon Aerial Photography, Inc.).

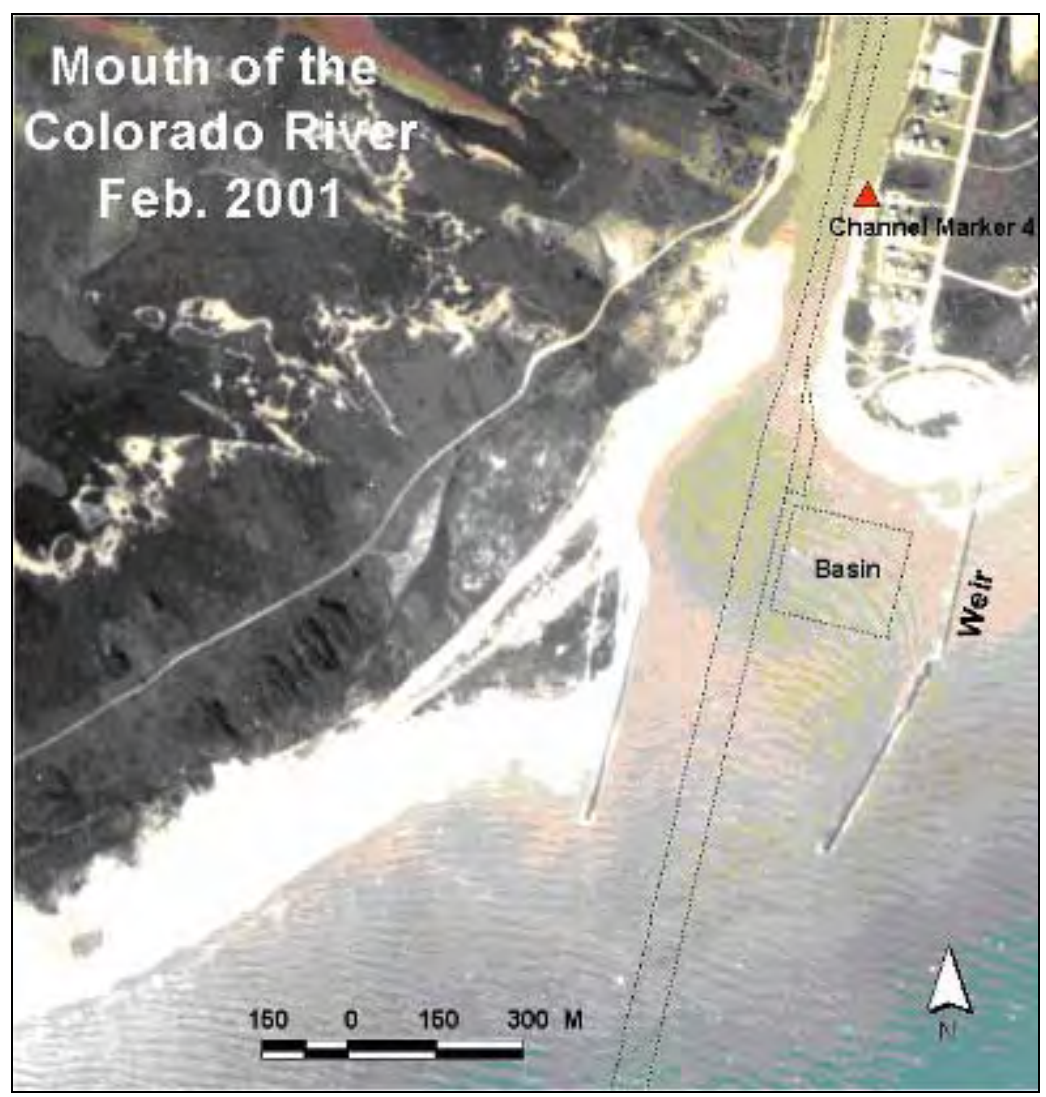

Figure 5. MCR, with navigation project features indicated (Lanmon Aerial Photography, Inc.). 
The GDM (USACE 1977) for the MCR navigation features estimated a 2-year maintenance dredging interval with a maximum 600,000-cu yd volume to be dredged. However, the existing dredging and sand bypassing system have not performed as intended, with the entrance channel nearly closed within 4 to 6 months after dredging. The impoundment basin is both rapidly filled and flanked on the landward side by sediment, primarily sand, transported in the swash zone. The flanking has created a spit that enters the navigation channel from the east. As a response to the spit encroachment and other factors, the western shore has become indented, as the channel narrows and migrates westward in the entrance (Figure 4). These processes are discussed in the following section.

\section{Previous studies}

In year 2000, the Galveston District's Navigation Branch requested that ERDC's Coastal and Hydraulics Laboratory conduct a study to investigate causes of the excessive shoaling at the MCR. To this end, review of the literature, morphologic analysis, field data collection of water level and current in the CRNC, and numerical modeling of tidal hydrodynamics were performed, as documented in Lin et al. (2001, 2003), Kraus et al. (2002), and Barcak et al. (2007).

Along this section of the Texas coast, the direction of net longshore sediment transport is from east to west (USACE 1977; Heilman and Edge 1996; King and Prickett 1998). Beach sediment consists primarily of finegrained quartz sand. Impoundment of sediment east of the jetties and erosion west of the jetties at the Matagorda Ship Channel (located approximately 25 miles southwest of the Colorado River mouth; Figure 1) and dredging records for 1953-1954 at the river mouth led the Galveston District to conclude that the net longshore transport was on the order of $300,000 \mathrm{cu}$ yd/year, identified primarily as east-directed transport (USACE 1977).

Based on hydrographic surveys, the Galveston District also determined a shoaling rate of 900,000 cu yd between Parkers Cut and the MCR for a period of less than a year between 1973 and August 1974. This large shoaling rate was not considered representative, however (USACE 1977). Subsequent experience has indicated such a large shoaling rate is more typical than extreme. 
Photographs of the river mouth taken before jetty construction show a tendency for spit formation and growth westward from the east side, with no spit evident on the west side of the mouth. For these and other reasons, a weir was placed on the east jetty, and the impoundment basin was designed to hold a 2-year supply of trapped littoral sediment (estimated at 600,000 cu yd). During channel maintenance dredging, the Galveston District pumps all material dredged to the down-drift beach to the west of the west jetty as a least-cost disposal alternative, and to continue bypassing of material in the net direction of transport. This procedure has reduced recession of the shoreline along the beach west of the jetties on this regionally eroding coast.

\section{Jettied inlet efficiency}

As part of studies conducted for the Galveston District, the efficiency of selected inlets on the Texas coast was examined, as recently reviewed by Kraus (2007). An inlet channel will function better in maintaining depth if it is narrow and deep (J arrett 1976). This geometrical consideration is in addition to consideration of the tidal flow through an inlet, with a stronger flow indicating more scouring potential and maintenance of channel crosssectional area.

Table 1 compiles information on five Texas coastal inlets. Of these, the Colorado River, Mustang Island Fish Pass, and Mansfield Pass (denoted in bold) have proven to be unstable or have even closed, whereas Aransas Pass and Packery Channel have remained open. It is seen that the widthto-depth ratios of Aransas Pass and Packery Channel are relatively small, promoting channel cross-sectional stability. Therefore, a new design for the MCR should include a small width-to-depth ratio.

Table 1. Approximate geometry of five Texas Gulf Coast entrances.

\begin{tabular}{|l|l|l|l|l|}
\hline Inlet Entrance & $\begin{array}{l}\text { Jetty Length } \\
\mathrm{m}\end{array}$ & $\begin{array}{l}\text { Width Between } \\
\text { Jetties } \\
\mathrm{m}\end{array}$ & $\begin{array}{l}\text { Entrance } \\
\text { Channel Depth } \\
\mathrm{m}\end{array}$ & $\begin{array}{l}\text { Width-to-Depth } \\
\text { Ratio }\end{array}$ \\
\hline Colorado River & $\begin{array}{l}\text { East 425, } \\
\text { West 180 }\end{array}$ & 400 & 4 & 100 \\
\hline Aransas Pass & $\begin{array}{l}\text { North 3,500, } \\
\text { South 2,750 }\end{array}$ & 400 & 15 & 27 \\
\hline Mustang Fish Pass & Both 265 & 122 & $2.4,1.2$ & 50,100 \\
\hline Packery Channel & Both 425 & 91 & $3.4,2.4$ & 27,38 \\
\hline Mansfield Pass & Both 410 & 305 & $4.7,3.7$ & 82 \\
\hline
\end{tabular}




\section{Morphology change}

The history of the original Colorado River mouth and present navigation project is given by USACE (1977, 1992), Ralston (1987), Heilman and Edge (1996), and King and Prickett (1998). Here, morphologic behavior is illustrated by inspection of selected representative aerial photographs (Figure 6). Prior to construction of the jetties in the late 1980s and early 1990s, the mouth of the Colorado River tended to be skewed to the west (top two photographs, 1954 and 1976), inferred to be caused by response of the channel to spit growth from the east and the strong net sediment transport from the east.

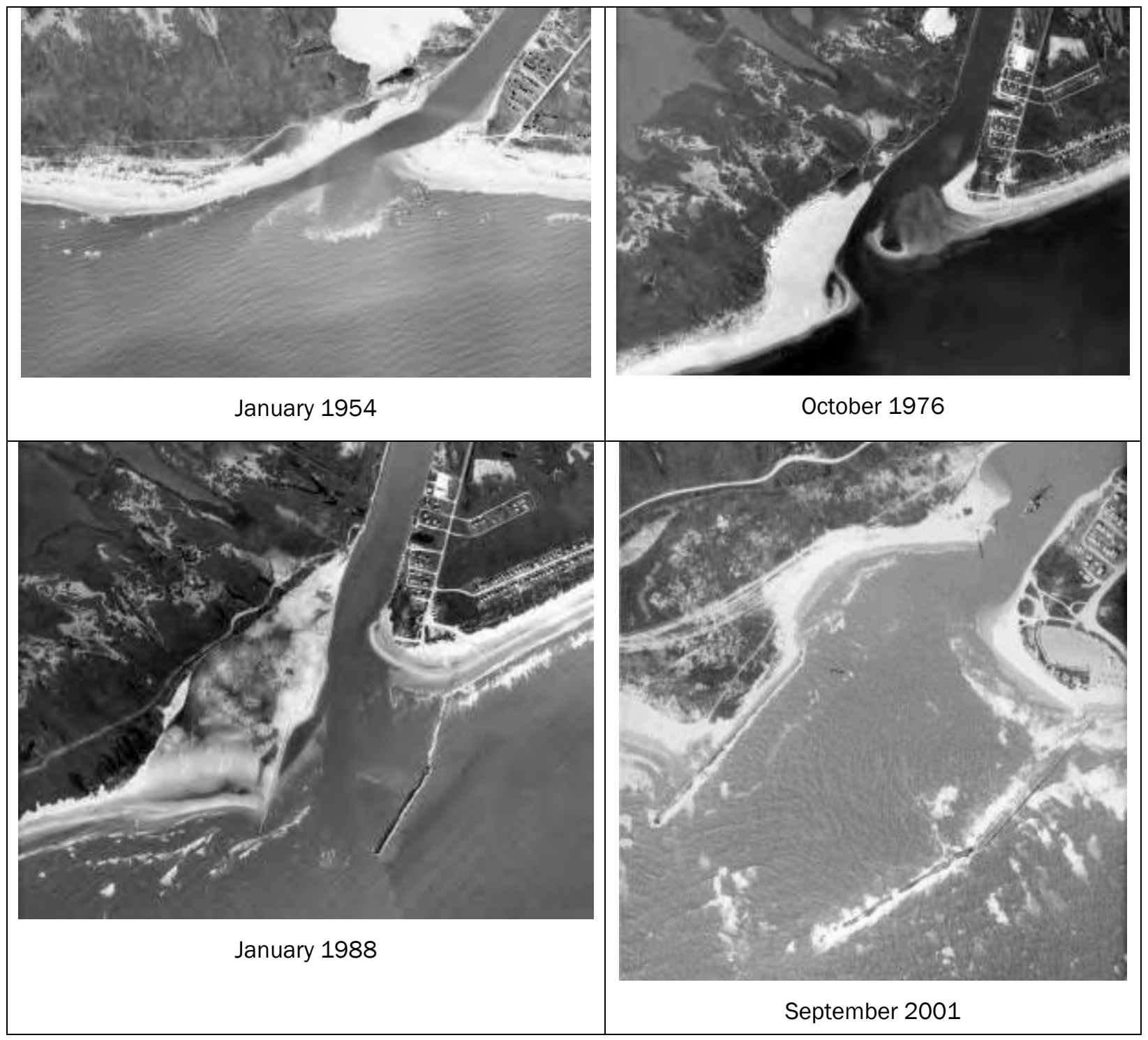

Figure 6. Morphologic behavior of MCR. 
After construction of the jetties and weir (Figure 6; bottom two photographs, 1988 and 2001), the position of the channel became more stable, and vessels could exit heading into the typical waves as opposed to being struck broadside as could occur with a skewed channel in the absence of jetties. However, spit encroachment from the east still occurs. Sand tends to bypass the weir and impoundment basin by moving alongshore in the swash zone inside the jetty system. The impoundment basin also poses a potential safety issue in presenting deep water relatively close to shore, where wade fishing is popular.

In addition, the landward side of the west jetty has now become eroded into a half-moon bay shape commonly observed at inlets. The shoreline recession on the west bank can be caused by waves and currents as described by Seabergh (2002), as well as by migration of the channel westward in response to spit encroachment from the east.

Other sediment pathways and sources of material entering the mouth are infiltration of material around the west jetty that is placed there during dredging, scour of the CRNC bottom, wind-blown sand, and material brought to the entrance by waves and the flood current. The relatively great distance between the gulfward ends of the jetties (1,350 ft) and the long weir $(1,000 \mathrm{ft})$ allow substantial wave penetration to the entrance and impoundment basin, acting to mobilize and move sediment under imposition of any current.

Sediment shoaling in the channel and impoundment basin is illustrated in Figures 7 and 8 . The cross section in Figure 7 is located in the vicinity of the spit that extends from the east. The impoundment basin tends to fill most in its northeast corner, closest to the beach. Some scour of the navigation channel north of the entrance is seen in Figure 8, suggesting this area as a source of sediment. 


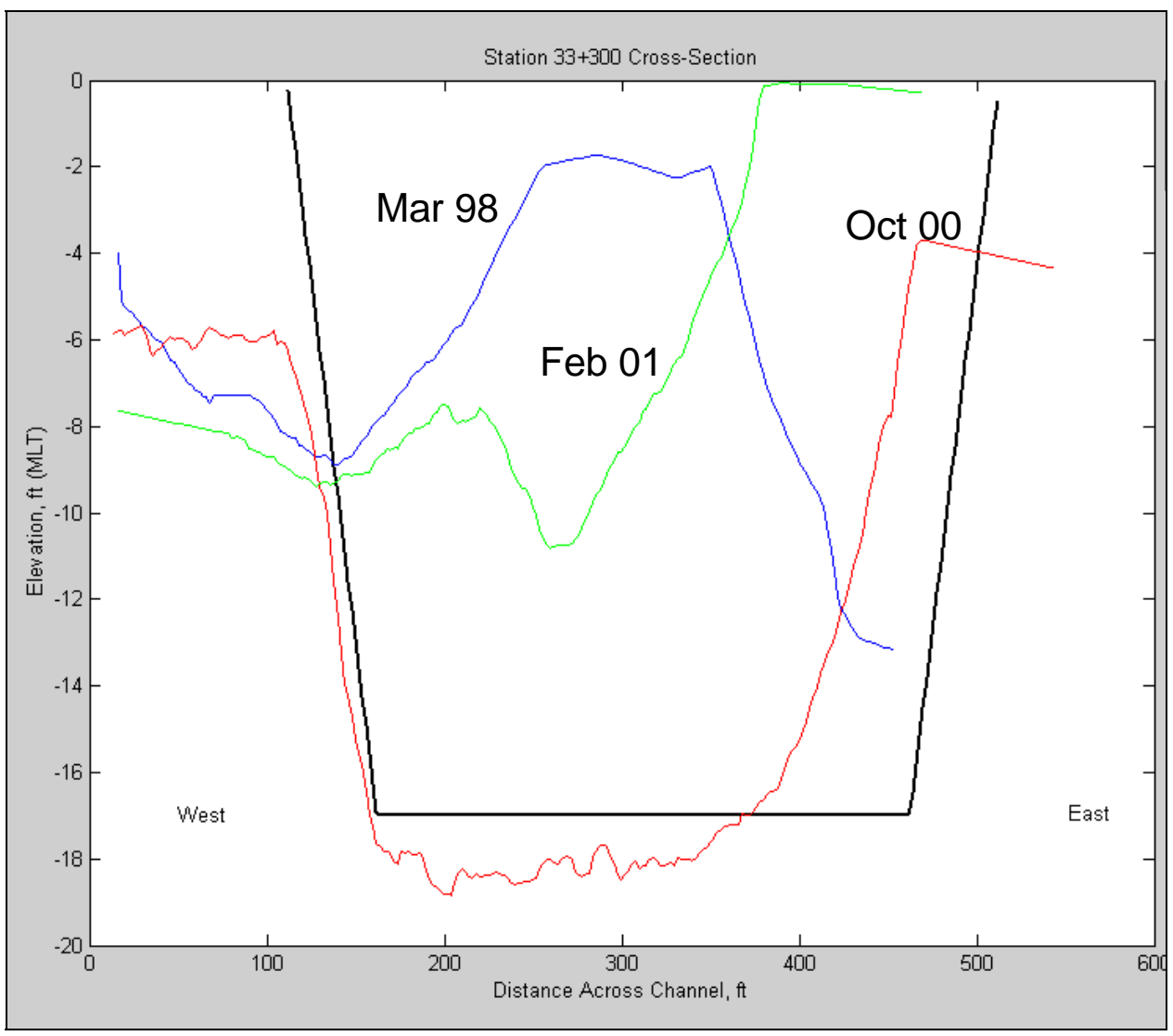

Figure 7. Example channel cross section before and after dredging.

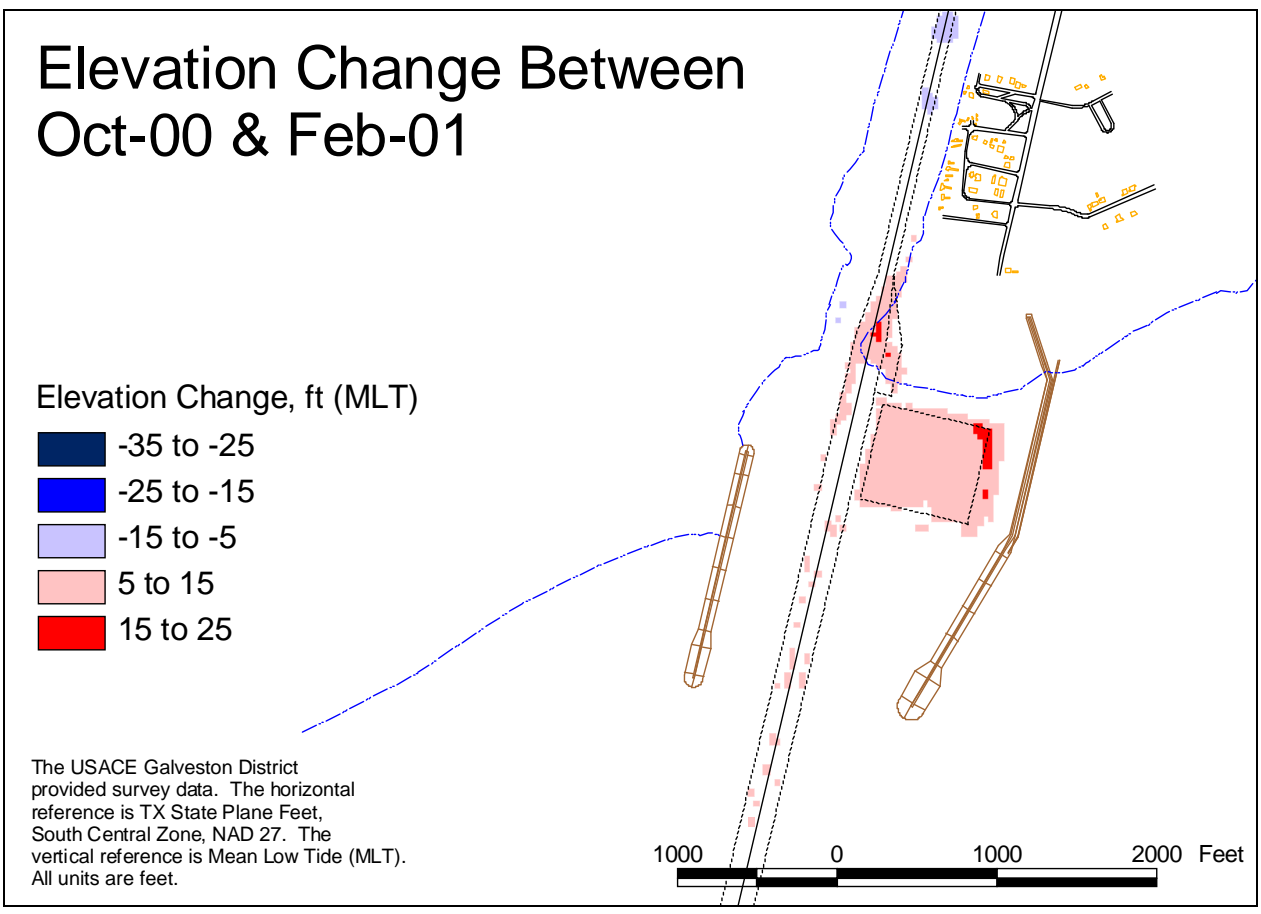

Figure 8. Elevation change in impoundment basin and navigation channel. 


\section{Ebb-shoal development}

Tidal inlets typically possess geomorphic features called ebb-tidal shoals or ebb-tidal deltas and flood-tidal shoals or flood-tidal deltas. The flood shoal consists primarily of material transported into the inlet on flood tide. Ebb-tidal shoals are formed of material transported by waves and tidal currents. Surveys conducted by CHL for the Galveston District indicate that the MCR presently has no ebb- or flood-tidal shoals, probably owing to the weak tidal and river current flowing through the existing channel.

The question arises as to whether an ebb-tidal shoal might form for the configuration of a new east jetty and more efficient channel. Modeling of long-term (several years) morphologic change was beyond the scope of this study. Considering available morphologic information, it is noted that neither Packery Channel in Corpus Christi nor Mansfield Pass in Willacy County, TX, have ebb shoals, based on recent surveys conducted for the Galveston District. It is concluded that sand brought to the entrance of the new jetty system will be transported west and bypass the channel based on calculations described in Chapter 3.

\section{Synthesis of findings and development of alternatives}

Based on information presented above, selected sediment pathways and sources of material are depicted in Figure 9. Main conclusions of the analysis are summarized below. These conclusions were derived through combined morphologic analysis, hydrodynamic modeling, and nearshore wave information as described in Lin et al. $(2001,2003)$ and Kraus et al. (2002).

1. The 1992 river diversion reduced the scouring river flow, and river sediment supply was also reduced.

2. The jetties are spaced too wide (weakens ebb flow and potential scouring action; allows too much wave penetration that can mobilize sand).

3. The weir is too long and too low (sand moves landward of basin; waves can penetrate easily and mobilize sediment for transport).

4. 4. The impoundment basin is bypassed on the landward side and is inefficient because of the stirring action by exposure to waves.

5. The spit growing from the eastern shore is the principal cause of channel shoaling, and it is fed by sediment bypassing landward of theimpoundment basin. 
6. There are several contributions and sediment pathways leading to channel shoaling, as summarized in Figure 9.

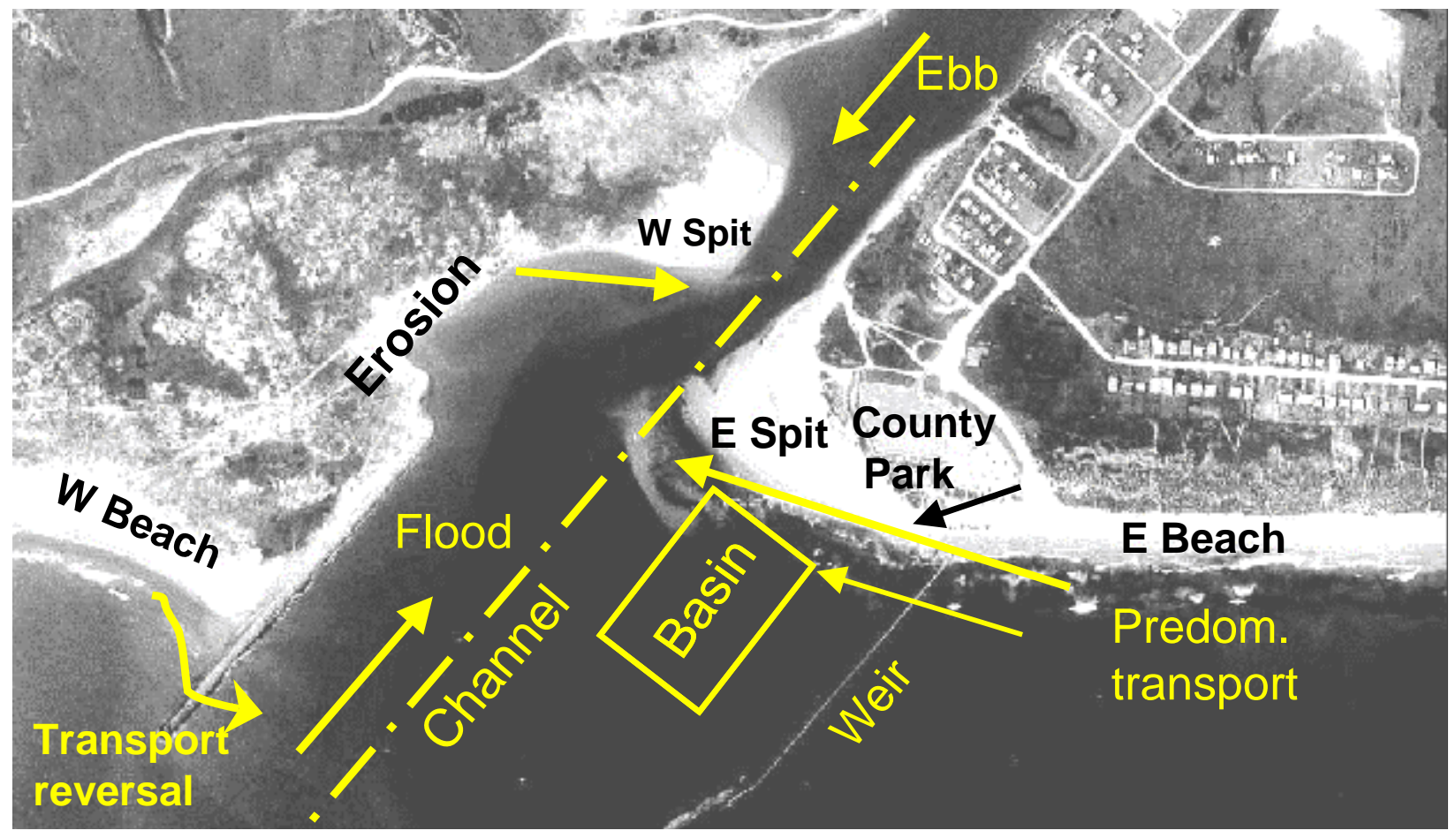

Figure 9. Major sediment pathways at MCR.

Understanding of the hydrodynamic and sediment-transport processes led to development of alternatives and conceptual examination of them in a systems approach that integrated major features of the project and surrounding environment. These features include (1) a reliable and costeffective navigation channel; (2) preservation of the county park and its facilities (Figure 9); (3) continued functionality of the popular fishing pier that runs parallel to the weir; and (4) continued bypassing of sediment across the mouth. Screening of the alternatives led to feasible actions that warranted further consideration, as listed in Table 2.

The concept was to take an incremental approach that might be feasible within the Galveston District operations and maintenance (O\&M) budget for improving navigation reliability at the MCR. The cost of design and construction of a new east jetty (Item 9 of Table 2), which represents a major structural solution to excessive shoaling, requires resources beyond the annual O\&M budget and is the subject of this report. 
Table 2. Alternatives that passed screening.

1. Maintain current practice.

2. Redesign the impoundment basin and modify the weir to be more efficient.

3. Construct a shore-normal impoundment basin sediment-training structure near the channel to reduce encroachment by the spit and to direct sediment moving alongshore in the swash zone and surf zone into the impoundment basin.

4. Raise a short section of the landward end of the weir to direct longshore transport into the impoundment basin.

5. Close the outer half of weir to reduce wave penetration into the entrance and impoundment basin.

6. Place pumped material farther westward of the west jetty to reduce its return during times of eastward longshore transport (by waves, wind, and flood tidal current).

7. Open the proposed Southwest Corner Cut (a proposed cut that would connect East Matagorda Bay with the Colorado River Navigation Channel), which would increase the ebb bias and ebb current magnitude.

8. Implement a combination of selected items listed above.

9. Construct a new east jetty approximately $800 \mathrm{ft}$ to the west without a weir or impoundment basin.

In year 2003, Item 3 of Table 2 was implemented. A 500-ft-long sedimenttraining structure consisting of quarry stone and sheet pile center was constructed west of the impoundment basin (Figure 10). Construction specifications are given in Turner, Collie \& Braden, Inc., \&DMJ M-Harris (2002). The structure, built at a cost of about $\$ 800,000$, functioned as intended in eliminating one dredging cycle. However, cessation of maintenance dredging following Federal Administration policy for shallowdraft channels caused bypassing of sediment around the seaward end in continuation of spit growth, and eventually the structure was buried by sand. A lesson learned was to elevate the landward portion of any such future structure, such as a new east jetty, to reduce infiltration by windblown sand into the channel that is transported from the dry beach.

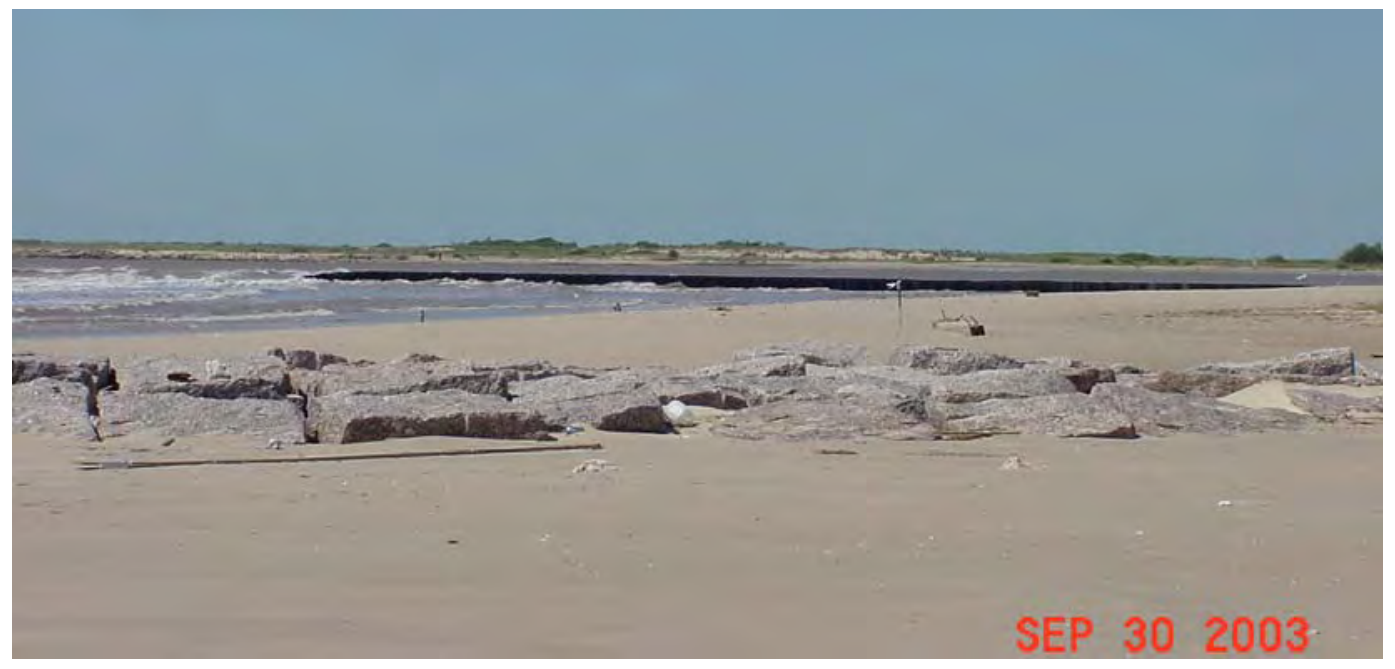

Figure 10. Sediment-training structure shortly after construction (landward side of east jetty weir in foreground, sediment-training structure in background at low tide). 


\section{Initial conclusions and proposed plan of action from previous studies}

Previous studies identified the causes of excessive shoaling at the MCR. The studies evaluated morphology change and channel behavior and were supplemented by hydrodynamic and wave modeling. It was concluded that tidal flushing was greatly reduced at this entrance after the Colorado River was diverted into Matagorda Bay. Spit growth from the east is a major factor causing the channel shoaling, although other sediment sources and pathways were identified. Placement of bypassed material farther west of the jetty than in previous practice would reduce potential for reintroduction of this material into the channel during times of reversals in longshore sand transport.

Consideration of the screened alternatives led to a proposed action plan of taking an incremental, adaptive-management approach to minimize potential unintended consequences and to allow evaluation at each step. This phased, incremental approach is summarized in Table 3. The approach allows improvements to be made at low cost to evaluate their effectiveness before implementing related, more major changes and modifications. The actions are depicted in Figure 11, where the numbers in the figure correspond to items in Table 3.

Table 3. Incremental approach to improve channel reliability at MCR (adapted from Kraus et al. 2002).

Phase 1

1. Construct $\sim 500$-ft-long impoundment basin training structure (prevent sand moving alongshore from entering the channel - eliminate the spit; maintain park property; maintain fishing pier functioning; direct sand into deposition basin).

2. Monitor the beach, channel, basin, and current in the entrance channel, as well as processes landward and Gulfward of the west jetty.

3. Place dredged sand farther westward (distance to be determined in further analysis).

4. If Step 1 is successful, raise the weir jetty near the shoreline for $\sim 250 \mathrm{ft}$ (force sand moving alongshore into the impoundment basin).

5. Close the outer half of the weir to reduce wave action.

Phase 2

6. If Phase 1 is successful, make final design based on monitoring (include evaluation of moving east jetty approximately $800 \mathrm{ft}$ westward).

7. Consider protection of shore along the west jetty landward embayment to reduce sediment infiltration to the channel and possible flanking of the jetty in time.

8. Consider lengthening the west jetty to reduce return of bypassed material.

9. Consider advanced maintenance dredging of the channel entrance.

10. The aforementioned actions may be sufficient to maintain a more reliable channel and predictable maintenance. If not, consider the functional design of a new east jetty to run straight out from the impoundment basin termination structure to produce a distance between the east and west jetties of $\sim 800 \mathrm{ft}$. This action would eliminate the weir and impoundment basin and would increase the scouring velocity of the ebb current. 


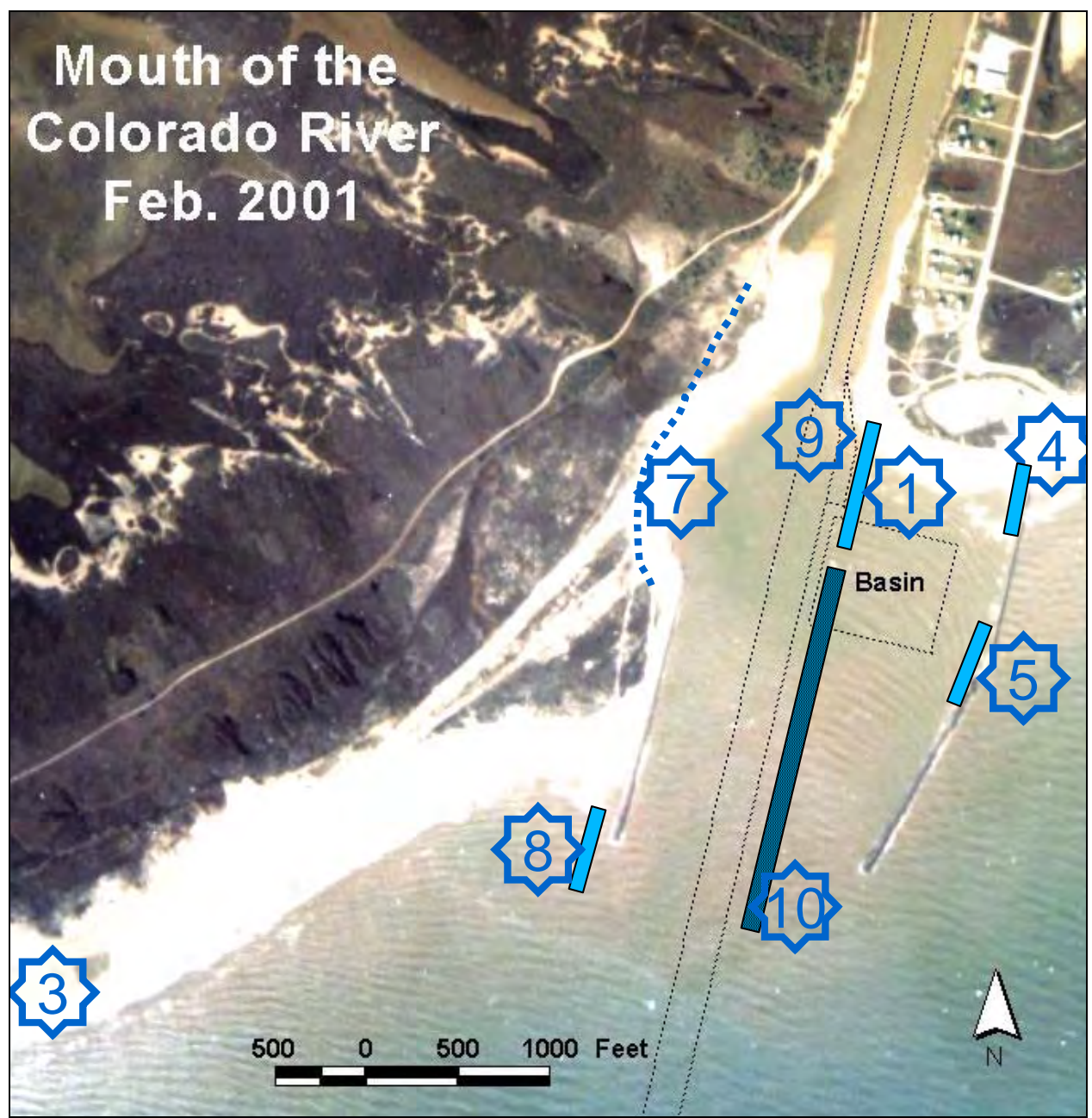

Figure 11. Incremental implementation of actions.

Most features in Table 3 are relatively low cost as compared to construction of a new east jetty (Item 10) that would be located closer to the channel to increase scouring action of the ebb flow and reduce wave penetration. Construction of a new east jetty represents a feasible structural solution if combined with prudent dredged material bypassing.

This report describes a comprehensive summary investigating the properties and efficiency of a new east jetty (Item 10 in Table 3), with work performed as described in the next section.

\section{Scope of report}

Chapter 1 of this report reviews coastal and inlet processes at the MCR and presents key findings of previous studies. Chapter 2 reviews the dredging record and history of long-term shoreline change at the MCR and presents 
results of numerical modeling of longshore sediment transport and shoreline change. Chapter 2 also gives recommendations about continued sediment bypassing practice. Chapter 3 and associated Appendixes A and B describe extensive calibration of a tidal hydraulics model, including development of the regional model required to force the project-scale model. The main objective of Chapter 3 is to present results of integrated numerical modeling of waves, current, sediment transport, and short-term (order of a month) bathymetry change in evaluation of a proposed new east jetty. Chapter 4 reviews stability, construction practice, and lessons learned from existing jetties along the Texas coast and then develops a preliminary design for the proposed new east jetty at the MCR. Appendix C compiles available aerial photography for the MCR. Appendix D documents the results of a geotechnical investigation for the new east jetty. Chapter 5 presents conclusions and recommendations of this study. 


\section{Shoreline Change and Longshore Sand Transport Rate}

This chapter describes the longshore sand transport rate, expected response of the shoreline to the proposed new east jetty, and required bypassing to maintain the western shore.

\section{Background on littoral processes}

\section{Observed shoreline change}

Long-term shoreline change on the Matagorda Peninsula was examined by Morton et al. (1976) through analysis of aerial photographs and topographic charts. They found the long-term net shoreline change rate between 1857 and 1974 was less than -1.0 ft/year directly east of the MCR and $-3.8 \mathrm{ft} /$ year directly west of the MCR, where (-) indicates recession and $(+)$ indicates advance. Here, the shoreline change rate after the Colorado River began discharging into the Gulf of Mexico in 1936 is calculated based on the Morton et al. (1976) data. The shoreline change rate between 1937 and 1974 was $-1.3 \mathrm{ft} /$ year directly east of the MCR and $-10.5 \mathrm{ft} /$ year directly west of the MCR. Morton et al. (1976) also analyzed shoreline change on shorter time scales, and the rates are summarized in Table 4. They note interrupted and decreased sediment supply, relative sea-level rise, and tropical storms as causes of erosion in the area and conclude that the beaches will continue to recede as part of a long-term erosional trend.

Shoreline change rate as a function of distance alongshore in the vicinity west of the MCR is plotted in Figure 12. Shoreline position was interpreted by geographic information system (GIS) analysis of rectified vertical aerial photographs taken after construction of the jetties. The rates between 1991 and 2000 and between 2000 and 2004 fall within the short-term ranges given by Morton et al. (1976). During these time periods, the impoundment basin and CRNC were dredged, and the material was bypassed to the west shoreline by hydraulic pump. The shoreline change rate is much greater between 2004 and 2006, a time interval during which no dredging occurred and, therefore, no material was bypassed. 
Table 4. Incremental shoreline change rates (from Morton et al. 1976).

\begin{tabular}{|l|l|l|l|l|}
\hline \multirow{2}{*}{ Location } & \multicolumn{4}{|c|}{ Rate (ft/year) } \\
\cline { 2 - 5 } & $1857-1937$ & $1937-1956$ & $1956-1965$ & $1965-1974$ \\
\hline East of MCR & $<-1.0)$ & +5.1 & -2.8 & -11.1 \\
\hline West of MCR & -3.1 & -12.8 & +47.2 & -41.7 \\
\hline
\end{tabular}

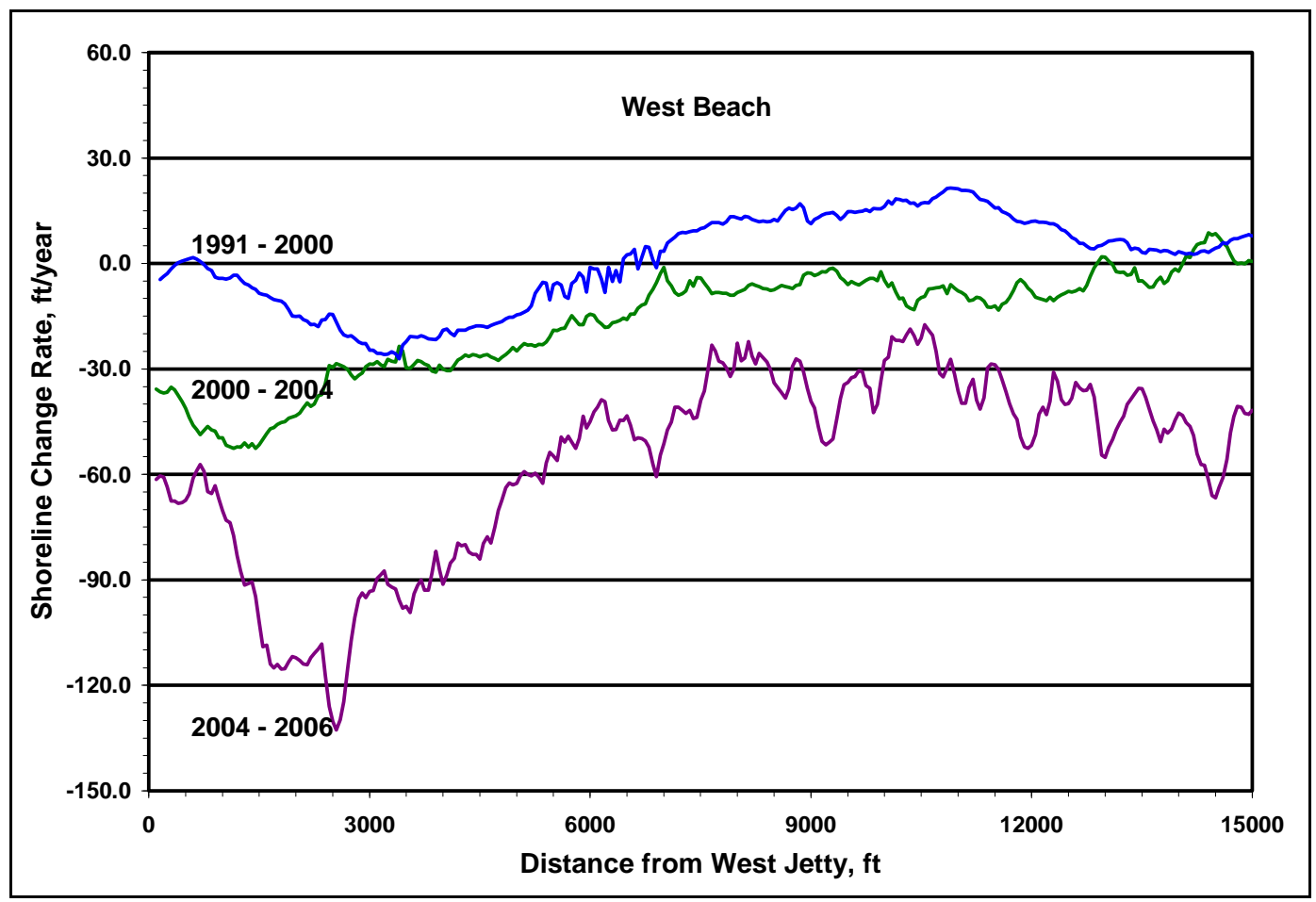

Figure 12. Shoreline change interpreted by GIS analysis from rectified aerial photographs.

\section{Longshore sand transport rate}

The MCR GDM (USACE 1977) estimated a net transport of $300,000 \mathrm{cu}$ yd/year to the west and negligible transport to the east, based in part on observed impoundment at the Matagorda Ship Channel east jetty located 25 miles to the southwest of the MCR. Heilman and Edge (1996) discussed sediment pathways and compiled estimates of longshore sediment transport on the Gulf of Mexico coast at the mouth of the Colorado River obtained from several sources and by different means of measurement or inference. They concluded that an average annual amount of 301,000 cu yd/year is necessary for sediment bypassing at the entrance. King and Prickett (1998) estimated the net rate of transport (the difference between eastward and westward transport rate) at MCR to be $668,000 \mathrm{cu} y d /$ year to the west, with a gross rate (the sum of eastward and 
westward transport rate) of 877,000 cu yd/year, based on the Shore Protection Manual (1984) CERC equation and intermittent wave measurements at the 10-m contour at the site. The King and Prickett (1998) measurements are biased toward winter and, hence, more extreme waves. These estimates (with empirical coefficient $\mathrm{K} 1=0.35$ for significant wave height; see Equation 2 below) are greater than the average annual volume removal of 556,000 cu yd/year and can be considered an upper limit.

For the present study, it was concluded that (1) calibration of the GENESIS shoreline change model to a westward transport of approximately 425,000 cu yd/year, (2) a net transport of approximately $200,000 \mathrm{cu} y d /$ year directed to the west, and (3) a gross transport of approximately 600,000 cu yd/year are compatible with both the dredging data and previous estimates of the longshore sand transport rate by wave action.

\section{Dredging}

The dredging record at the MCR will give an estimate of the longshore transport rate capacity at the site. Volume of sediment dredged in the basin and the CRNC from 1990 to 2002 is plotted in Figure 13, based on Galveston District records. Dredging volumes analyzed here for the 12-year interval from 1990 to 2002 indicate the average annual volume removal was 556,000 cu yd/year, which includes littoral sand and finer sediment dredged from the impoundment basin and the river channel.

Analysis of Galveston District records made by Lin et al. (2003) for the entrance channel and impoundment basin samples taken between February 1994 and September 1995 indicate that the sediment is primarily sand in the entrance channel, with some silt and clay found in the impoundment basin. The sediment in the entrance channel had a mean grain size of $0.12 \mathrm{~mm}$ and silt and clay fractions of 35 percent at some locations. The sediment in the impoundment basin had a mean grain size of $0.03 \mathrm{~mm}$ and contained 87 percent silt and clay fractions (Lin et al. 2003). Sediment samples taken in the CRNC show mean grain size of $0.04 \mathrm{~mm}$ and contained 60 to 80 percent silt and clay. The fine material in the basin and CRNC, silt- and clay-sized particles, is consistent with the sediment in the GIWW and from the river bed. The samples suggest that river sediments are reaching the MCR and likely settling into the impoundment basin. The river sediment would not originate from north of 
the Colorado River navigation locks, but from erosion of the CRNC extending from the GIWW to the MCR.

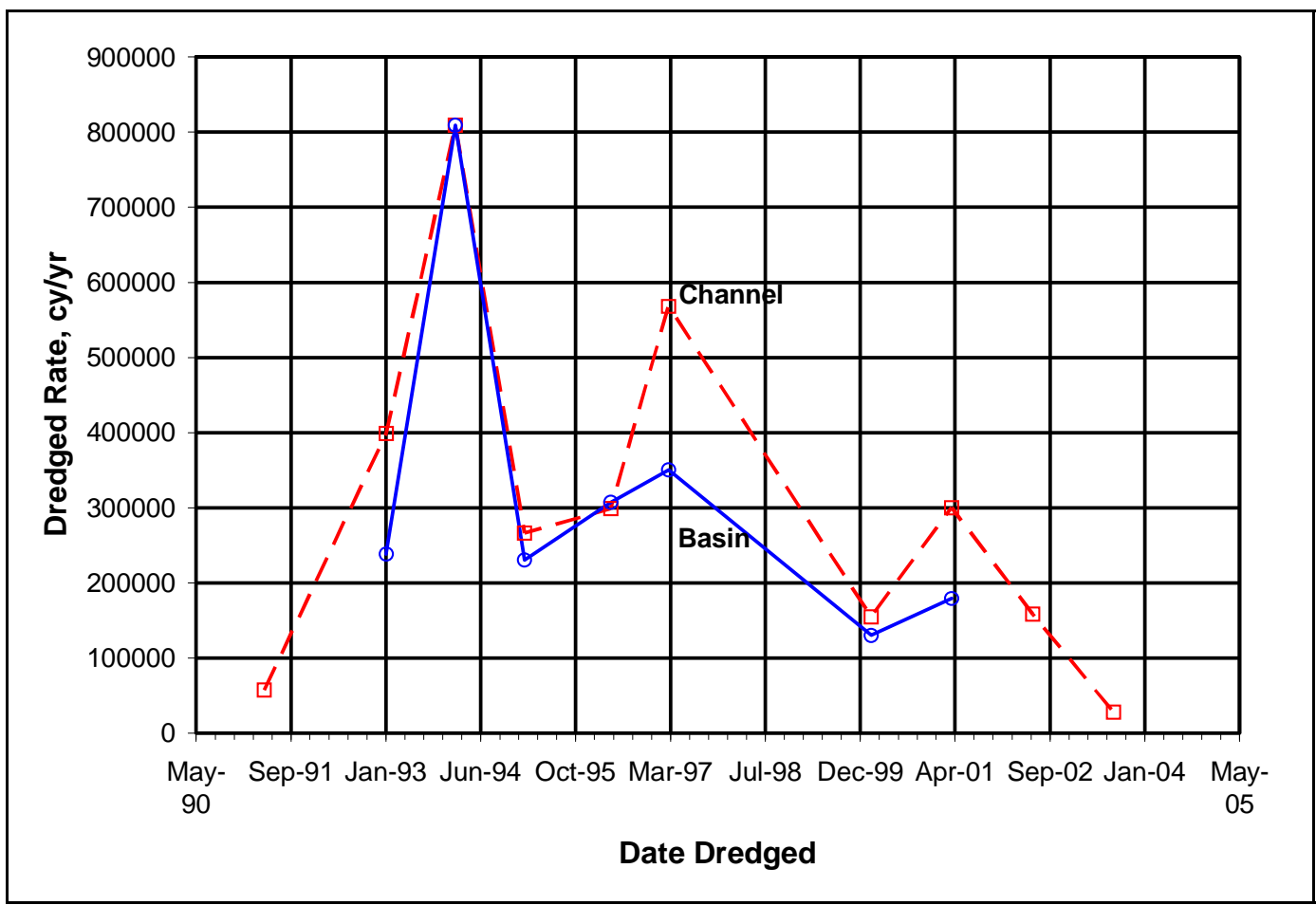

Figure 13. Dredging rates at MCR from May 1990 to present.

Of the average annual volume removal of 556,000 cu yd/year, it has been estimated that about 367,000 cu yd/year originates from the littoral zone, in agreement with the conclusion of Heilman and Edge (1996). The remainder, 189,000 cu yd/year, must therefore be supplied by the river bed and GIWW as primarily finer grained sediment. Littoral material can enter the impoundment basin and MCR from the east, west, and offshore, depending on the prevailing waves and current.

\section{Shoreline response model}

\section{Description of GENESIS}

Shoreline response and bypassing volume necessary to maintain the west beach were investigated with the GENESIS shoreline response model (Hanson and Kraus 1989). GENESIS was developed to simulate gradients in the longshore sand transport rate and the resultant change in shoreline position. A basic assumption underlying GENESIS is that the beach profile shifts landward or seaward, without changing shape, as the shoreline advances or recedes. Therefore, only one cross-shore point at each grid cell 
needs to be tracked. At each alongshore grid cell, the model calculates breaking wave height and direction, which are needed to calculate the temporally varying local longshore sand transport rate. GENESIS enables the prediction of shoreline evolution under a wide range of beach, coastal structure, wave, initial conditions, and boundary conditions.

GENESIS calculates the longshore transport rate by a form of the CERC equation (Shore Protection Manual 1984). The CERC equation estimates the longshore sand transport produced by obliquely incident breaking waves. Hanson and Kraus (1989) included an additional term to account for the longshore gradient in breaking wave height. The predictive equation for the longshore sand transport rate in GENESIS is:

$$
\mathrm{Q}=\left(\mathrm{H}^{2} \mathrm{C}_{\mathrm{g}}\right)_{\mathrm{b}}\left[\mathrm{a}_{1} \sin 2 \theta_{\mathrm{bs}}-\alpha \cos \theta_{\mathrm{bs}} \frac{\partial \mathrm{H}}{\partial \mathrm{x}}\right]_{\mathrm{b}}
$$

in which $\mathrm{Q}$ is the longshore transport rate, $\mathrm{H}$ is wave height, $\mathrm{C}_{\mathrm{g}}$ is group wave celerity, $\theta_{\mathrm{bs}}$ is breaking wave angle with respect to the shoreline, $\partial \mathrm{H} / \partial \mathrm{x}$ is longshore gradient in breaking wave height, and the subscript $\mathrm{b}$ denotes breaking wave condition. The coefficients $\mathrm{a}_{1}$ and $\mathrm{a}_{2}$ are dimensionless parameters defined as:

$$
\begin{gathered}
\alpha_{1}=\frac{K_{1}}{16\left(\frac{\rho_{s}}{\rho}-1(1-p)(1.416)^{5 / 2}\right)} \\
\alpha_{2}=\frac{K_{2}}{8\left(\frac{\rho_{s}}{\rho}-1(1-p) \tan \beta(1.416)^{7 / 2}\right)}
\end{gathered}
$$

where $K_{1}$ is an empirical coefficient typically ranging from 0.1 to $0.77, K_{2}$ is an empirical coefficient typically 0.5 to 1.0 times $K_{1}, \rho_{s}$ is density of sand, $\mathrm{p}$ is the porosity of the bed layer sand, and $\tan \beta$ is the average bottom slope within closure depth. The coefficients $\mathrm{K}_{1}$ and $\mathrm{K}_{2}$ serve as calibration parameters.

The first term in Equation 1 corresponds to the CERC equation and accounts for longshore transport produced by obliquely incident breaking waves. A value of $K_{1}=0.77$ was originally determined by Komar and 
Inman (1970) from their sand tracer experiments using root-mean-square (rms) wave height. The standard engineering quantity of significant wave height is converted to an rms value in GENESIS by the factor of 1.416 included in Equations 2 and 3.

The second term in Equation 1 describes the contribution of the longshore gradient of breaking wave height, and is not part of the CERC equation. The contribution of this term on an open coast is usually much smaller than that from oblique wave incidence. However, inclusion of the term in the vicinity of structures, where diffraction produces substantial change in breaking wave height over a considerable length of beach, provides an improved modeling result. The value of $\mathrm{K}_{2}$ is typically 0.5 to 1.0 times that of $\mathrm{K}_{1}$.

Data input into GENESIS includes initial shoreline position and wave data. Initial shoreline position was obtained from GIS analysis of rectified aerial photographs of the MCR taken in May 2006 available from the Texas General Land Office. These photographs are estimated to have accuracy of $\pm 1 \mathrm{~m}$. The MCR east and west shorelines were modeled separately, because the boundary condition at the river entrance is unknown.

\section{Wave component}

Wave Information Study (WIS) wave hindcast information (Tracy 2004) provided wave forcing, giving hourly information on wave height, period, and direction. Wave information from WIS sta 55, located off the coast of the MCR at 18-m water depth, was transformed to the GENESIS boundary depth of $15 \mathrm{~m}$ through a transformation program described by J ensen (1983). The transformation represents refraction, shoaling, and spectral evolution, and it provides information on nearshore wave height, period, and direction. Breaking wave height and depth were determined from the wave information at the boundary depth with the GENESIS internal wave model. The internal model is applicable to a sea bottom with approximately straight and parallel contours, which applies to the coastline in the vicinity of the MCR.

\section{Model configuration and verification}

GENESIS was applied to the east beach without the proposed east jetty installed and with the default $K_{1}$ value of 0.77 . The shoreline extended approximately 4 miles east of the inlet to ensure that all shoreline changes 
were captured and the shoreline was stable at the east boundary. The alongshore grid spacing was $50 \mathrm{ft}$. A simulation was performed for each year of WIS information between 1980 and 1999. Statistical results of the initial GENESIS calibration are given in Table 5. The average sand transport rates calculated with a design value of $K_{1}=0.77$ are much greater than the target rate, indicating $K_{1}$ should be reduced. Such a reduction is typical (Bodge and Kraus 1991) and may be attributed in part to wave hindcast limitations and site-specific conditions.

Table 5. Variability in annual potential longshore sand transport rates $(1,000 \mathrm{cu}$ yd) on east beach calculated from 20-year WIS wave hindcast (positive net transport to west, $K_{1}=0.77$ ).

\begin{tabular}{|l|c|l|c|l|}
\hline Quantity & Net Rate & Gross Rate & Transport West & Year \\
\hline Minimum Net & 379 & 1,536 & 957 & 1989 \\
\hline Maximum Net & 1,419 & 2,084 & 1,752 & 1998 \\
\hline Minimum Gross & 748 & 1,202 & 975 & 1992 \\
\hline Maximum Gross & 1,419 & 2,084 & 1,752 & 1998 \\
\hline Min West & 493 & 1,338 & 915 & 1999 \\
\hline Max West & 1,419 & 2,084 & 1,752 & 1998 \\
\hline Average & 783 & 1,537 & 1,160 & \\
\hline Standard Dev. & 234 & 208 & 196 & \\
\hline
\end{tabular}

GENESIS simulations were performed on the east beach for each year of WIS information with $K_{1}=0.27$. The statistical summary, provided in Table 6, shows that the reduced coefficient gives reasonable averages for the estimated net, gross, and westward transport rates.

Table 6. Variability in annual potential longshore sand transport rates $(1,000 \mathrm{cu} y \mathrm{~d})$ on east beach calculated from 20-year WIS wave hindcast (positive net transport to west, $K_{1}=0.27$ ).

\begin{tabular}{|l|l|l|l|l|}
\hline Quantity & Net Rate & Gross Rate & Transport West & Year \\
\hline Minimum Net & 136 & 541 & 339 & 1989 \\
\hline Maximum Net & 504 & 736 & 620 & 1998 \\
\hline Minimum Gross & 264 & 422 & 343 & 1992 \\
\hline Maximum Gross & 504 & 736 & 620 & 1998 \\
\hline Min West & 177 & 473 & 325 & 1999 \\
\hline Max West & 504 & 736 & 620 & 1998 \\
\hline Average & 278 & 542 & 410 & - \\
\hline Standard Dev. & 83 & 73 & 69 & -- \\
\hline
\end{tabular}


GENESIS was applied with $\mathrm{K}_{1}=0.27$ to the 4 -mile-long east beach shoreline with the proposed east jetty installed. The depth at the new east jetty was approximately $12 \mathrm{ft}$ and simulated as a gated structure (meaning that sand can bypass under natural conditions, which would then enter the channel entrance), with permeability equal to zero. Figure 14 shows calculated westward, net, and gross transport rates as a function of distance from the inlet for the 20-year WIS hindcast from 1980 to 1999. The transport rates approach zero near the jetty but show little alongshore variation eastward beyond 15,000 $\mathrm{ft}$ from the jetty, indicating the shoreline is fairly straight. The rates are similar to the respective target calibration rates. The gross rate is on the order of 650,000 cu yd/year, net rate is approximately $210,000 \mathrm{cu} \mathrm{yd} /$ year west, and westward transport rate is approximately $430,000 \mathrm{cu} \mathrm{yd} /$ year.

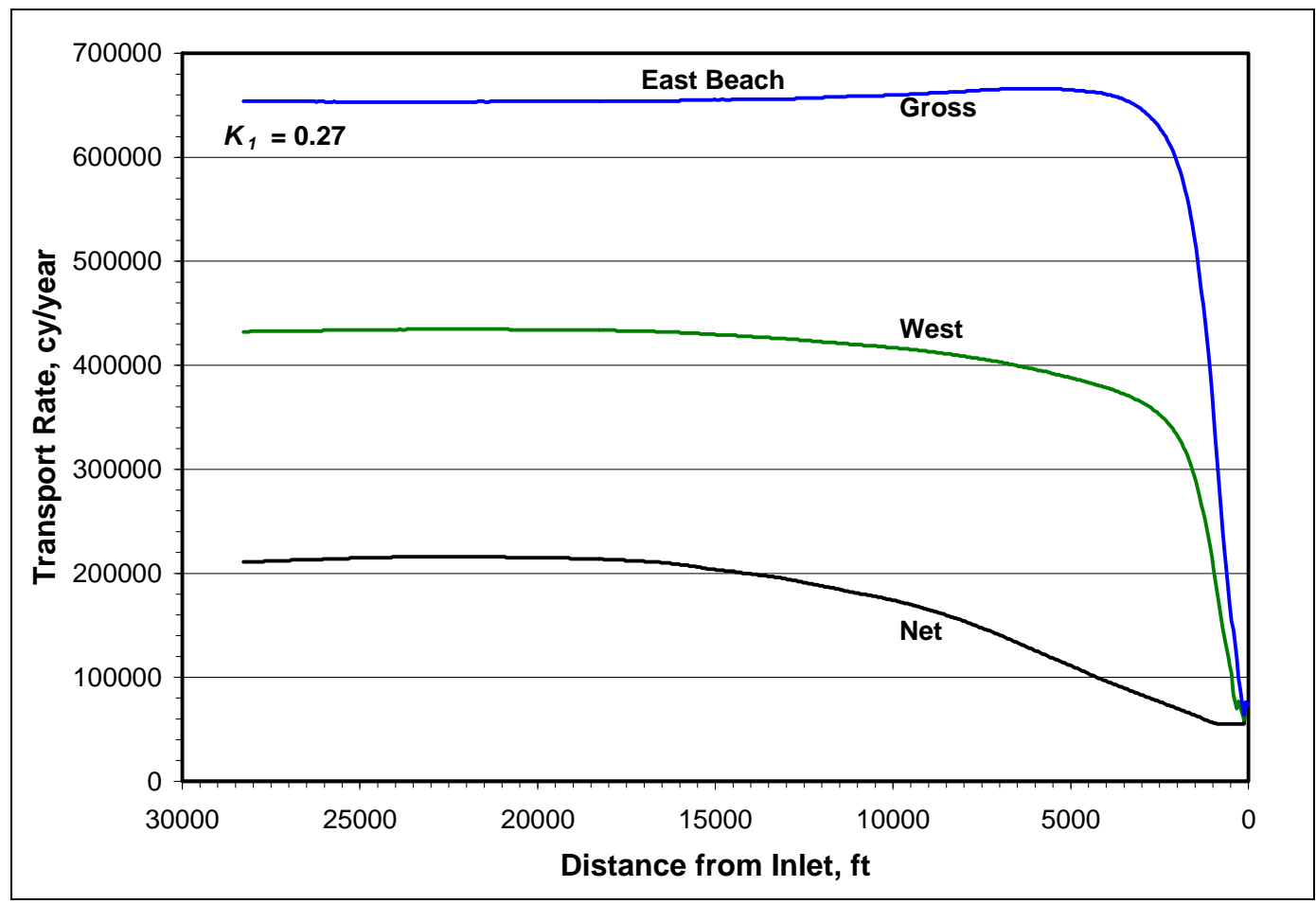

Figure 14. East Beach longshore transport rates as function of distance from east jetty.

Transport rates also were calculated for the west beach using the 20-year WIS hindcast from 1980 to 1999. The west beach shoreline extended west 4 miles from the existing west jetty to a location where the shoreline was stable to include all shoreline changes, also with an alongshore grid spacing of $50 \mathrm{ft}$. The west jetty was included on the western boundary at a depth of $8 \mathrm{ft}$ (based on the December 2006 survey data) as a gated structure with permeability of zero and an orientation to the shoreline of 
-10 deg. Figure 15 shows gross, net, and westward transport rates as a function of distance from the west jetty. The rates approach zero near the jetty and become uniform 15,000 ft from the jetty, indicating a shoreline that is fairly straight. The calculated gross rate at the western boundary is approximately 650,000 cu yd/year, with net rate of 190,000 cu yd/year, and westward transport rate of 420,000 cu yd/year.

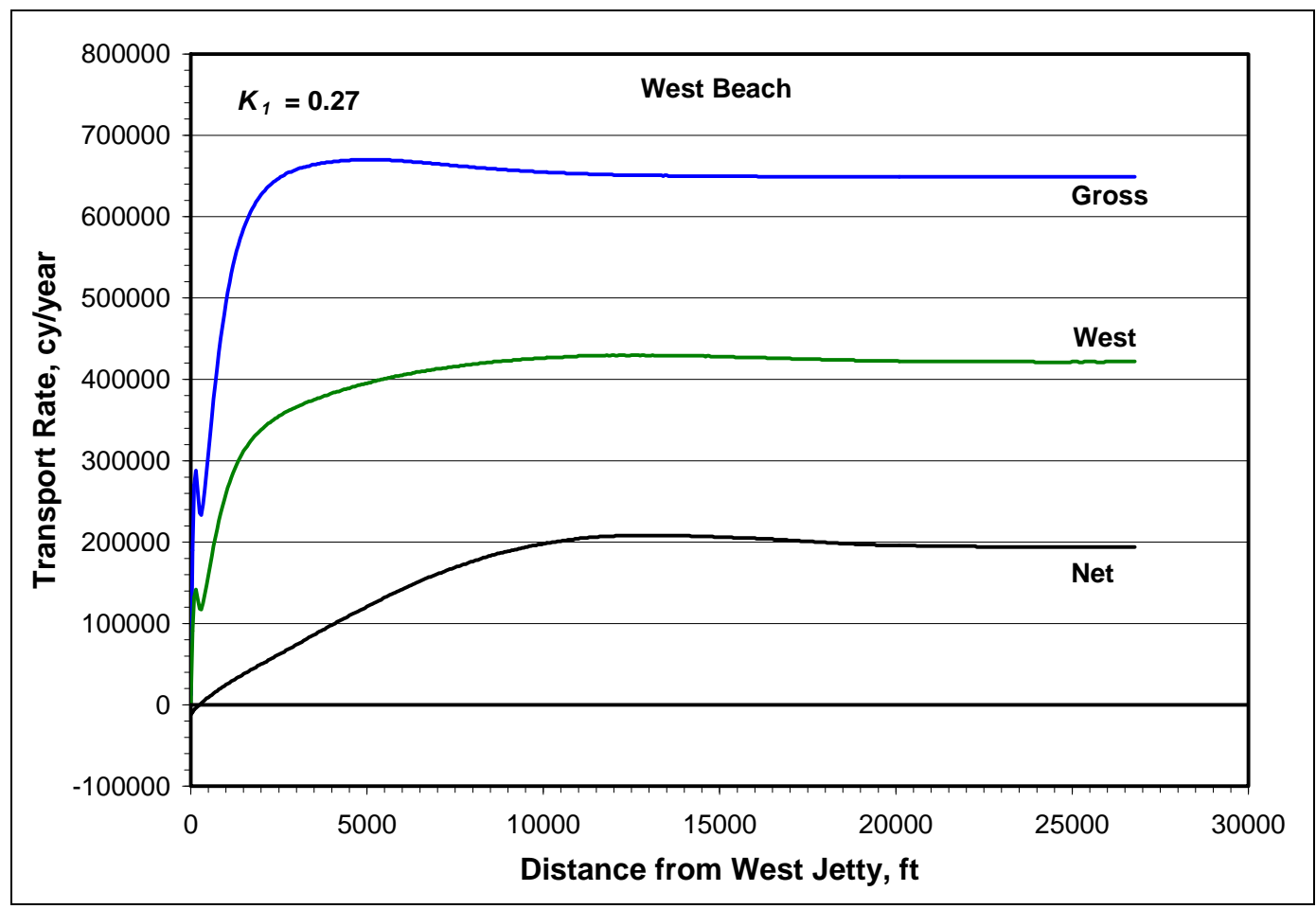

Figure 15. West Beach longshore transport rates as function of distance from west jetty.

\section{Natural bypassing of jetties}

Figures 14 and 15 show that transport rates decrease near the jetties, but are not zero at the boundary. The non-zero value indicates that sand bypasses the jetties into the entrance channel. The volume of sand bypassing the east and west jetty during each year of the 20-year GENESIS simulation is shown in Figure 16. Predominant transport is to the west; therefore, a greater volume of sand bypasses the east jetty. Two factors that influence the amount of sand that bypasses a jetty are the wave condition and distance from the shoreline to the jetty tip (giving a depth at the jetty tip) (Hanson and Kraus 1989). The east jetty is not bypassed during the first 4 years when the shoreline is not close to the jetty tip. As the jetty becomes impounded (discussed in the next section), bypassing occurs more regularly. Results of this analysis are: 
1. The average volume of sand bypassing the east jetty is $74,000 \mathrm{cu}$ yd with a standard deviation of 115,000 cu yd.

2. The maximum sand volume bypassing the east jetty is 375,000 cu yd and occurs during WIS year 1993.

3. The average sand volume bypassing the west jetty is $12,000 \mathrm{cu}$ yd with a standard deviation of 22,000 cu yd.

4. The maximum volume of sand bypassing the west jetty is 75,000 cu yd and occurs in WISyear 1980.

5. The east jetty is not bypassed in 8 years, and the west jetty is not bypassed in 11years.

6. The total volume of sand bypassing the east and west jetties over the 20-year simulation is 1.7 million cu yd.

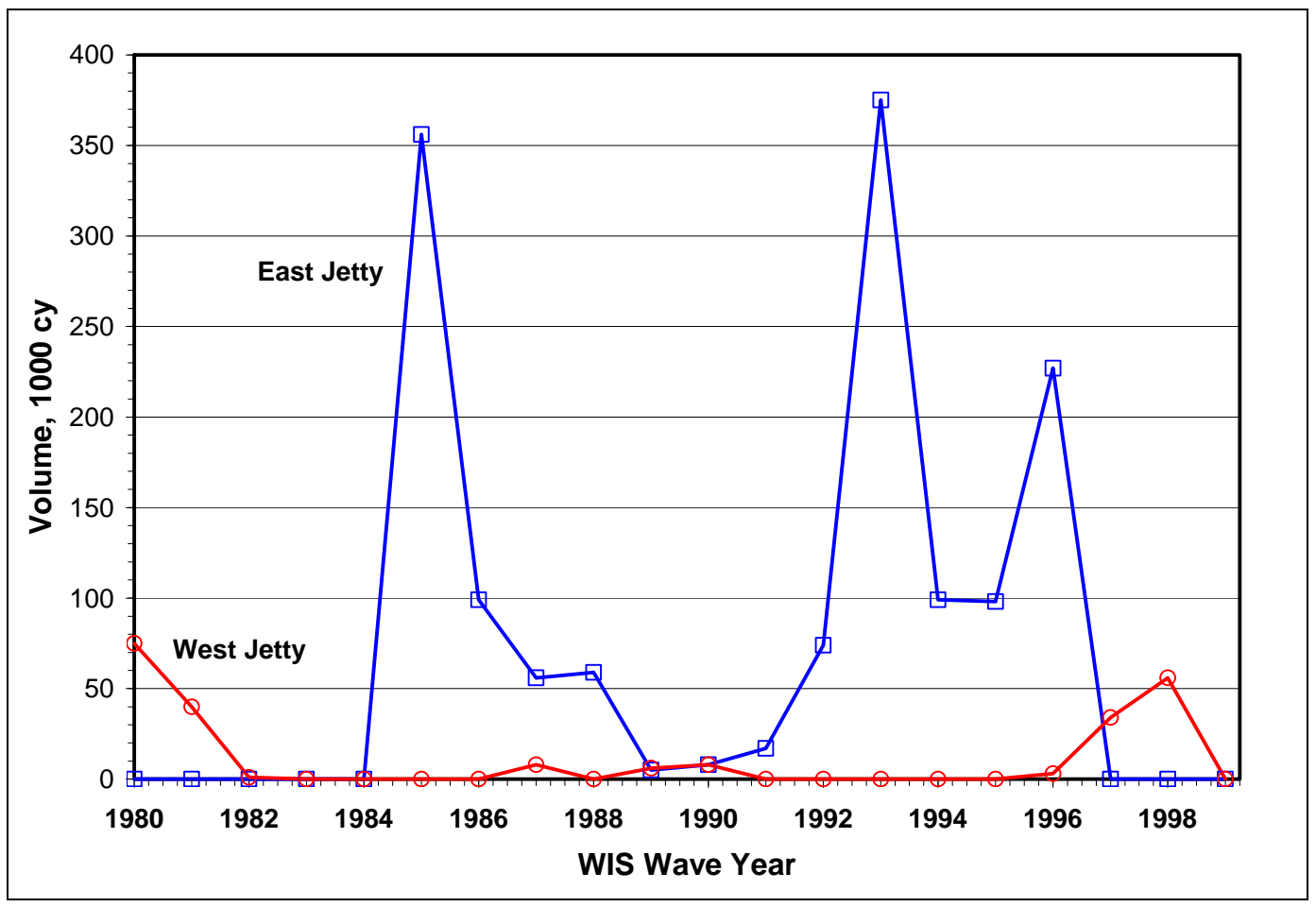

Figure 16. Volume of sand by year bypassing east and west jetties.

GENESIS modeling indicates that a significant volume of littoral sand will enter the CRNC if sand is not mechanically bypassed from the east beach to the west beach. 


\section{Shoreline response without mechanical bypassing}

The shoreline response model was run to predict shoreline position with the new east jetty in place after 20 years without mechanical bypassing of sediment to the west beach, as through maintenance dredging. The calibrated GENESIS was applied to both the east and west beaches. Without mechanical sand bypassing, the model predicts significant accretion on the east side and erosion along the beach on the west side of the MCR. Figure 17 shows predicted shoreline change east of the jetties in increments of 5 years. The shoreline near the east jetty advances for the first 15 years. Large storms in the WIS between years 15 and 20, particularly the 19th year (WIS year 1998), led to shoreline recession between years 15 and 20. The line labeled "maximum" defines the maximum gulfward limit of the shoreline. The figure indicates that, at times, the east jetty could be impounded if no sand is removed from the impoundment fillet, and sand would increasingly bypass to the entrance. Figure 17 shows accretion of the east beach with the proposed jetty, whereas Morton et al. (1976) found erosion of $1.3 \mathrm{ft} /$ year or $26 \mathrm{ft}$ over 20 years.

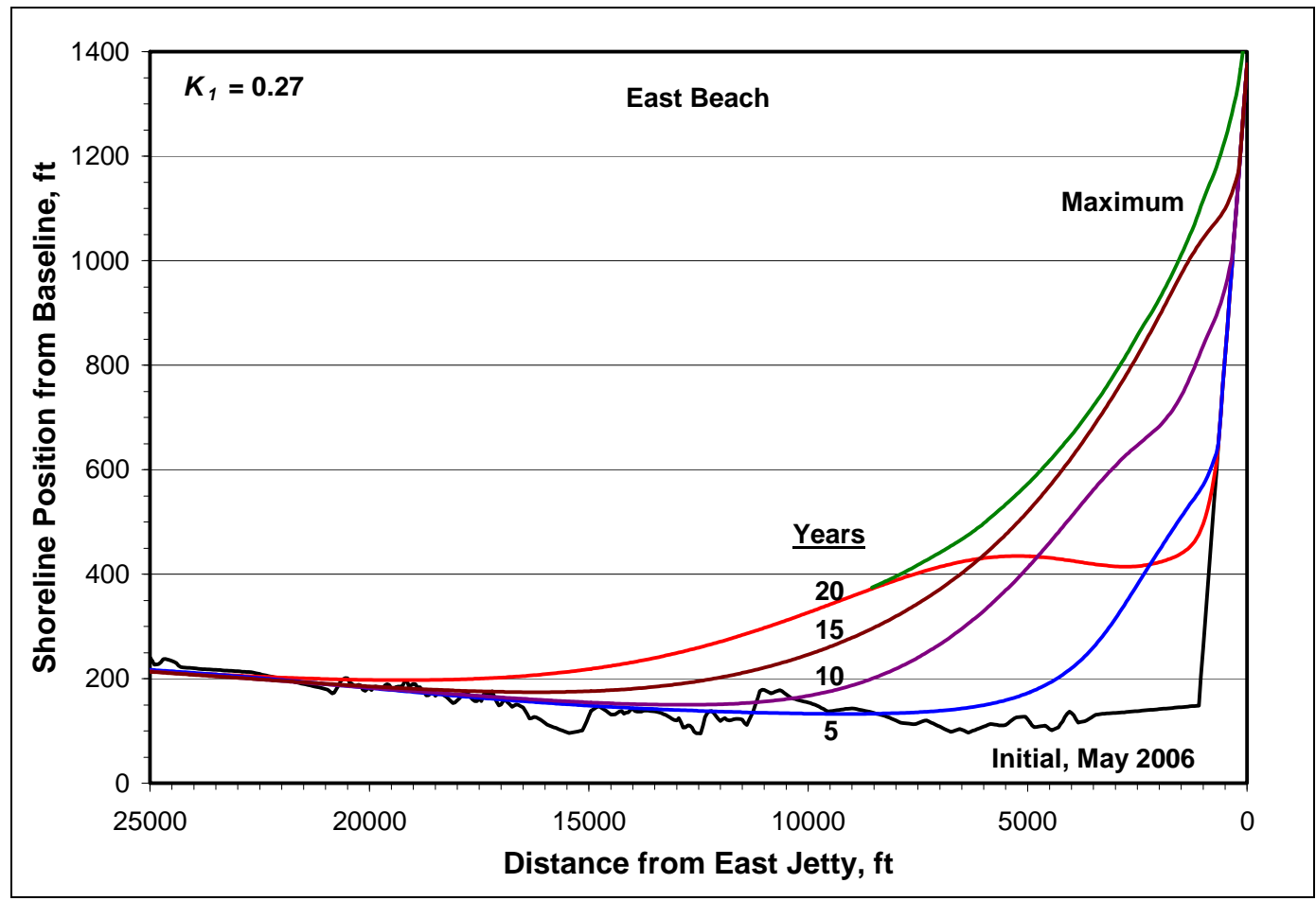

Figure 17. Predicted shoreline change, east beach. 
Figure 18 shows predicted shoreline change without sand bypassing on the west side of the jetties in 5-year increments. Incremental shoreline recession occurs near the jetty for the first 15 years. The shoreline recovers between the 15th and 20th years because of the WIS wave variability during these years. The average shoreline change within 1 mile of the west jetty after 20 years is - $564 \mathrm{ft}$, and the maximum shoreline change is $-1,739 \mathrm{ft}$ adjacent to the west jetty in year 15 . Morton et al. (1976) found the shoreline directly west of the inlet receded $10.5 \mathrm{ft} /$ year, or $210 \mathrm{ft}$ over 20 years. The results indicate that the west jetty could be flanked if sand is not bypassed to the west beach because of the considerable shoreline recession that can occur there.

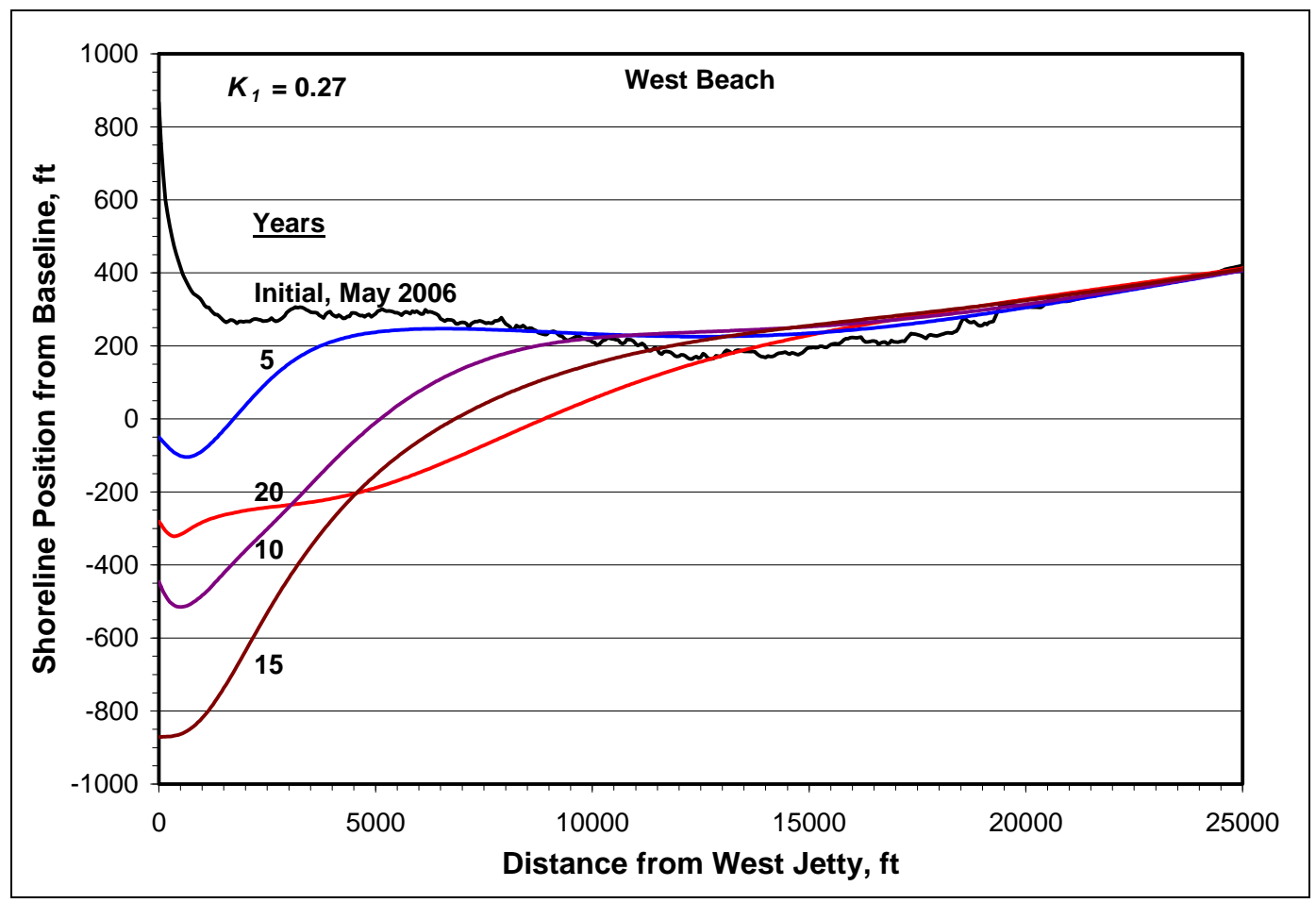

Figure 18. Predicted shoreline change, west beach.

\section{Shoreline response with mechanical bypassing}

Shoreline change also was calculated including simulated mechanical bypassing (dredging) of the up-drift accretion fillet at the east jetty. A volume of 400,000 cu yd was bypassed every 2 years and placed on the down-drift beach over a 10-year interval. Figures 19 and 20 show calculated shoreline positions with and without bypassing running WIS waves from 1980 to 1989, and from 1990 to 1999, respectively. The difference in shoreline positions between the two figures illustrates the response of the shoreline to wave variability. Both figures indicate that bypassing is 
essential to maintain the beach to the west, continuing the Galveston District's past practice of dredging the impoundment basin and channel, and placing all material on the western beach by pipeline. Periodic bypassing will prevent a large fillet from forming, which would more readily allow littoral material to shoal in the entrance channel from the east beach.

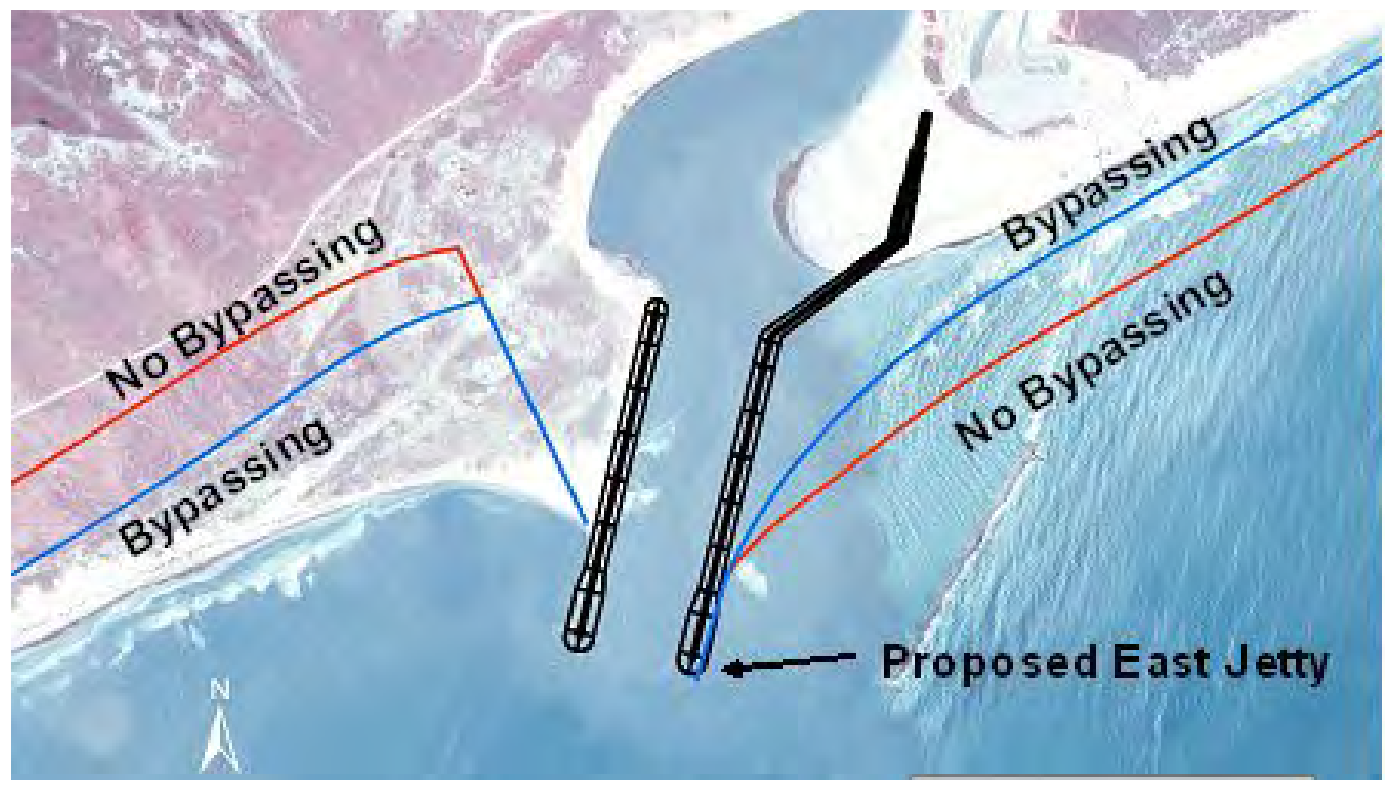

Figure 19. Shoreline position after 10 years of WIS waves from 1980 and 1989 with proposed jetty design, with and without sediment bypassing from up-drift to down-drift beaches (photograph May 2006).

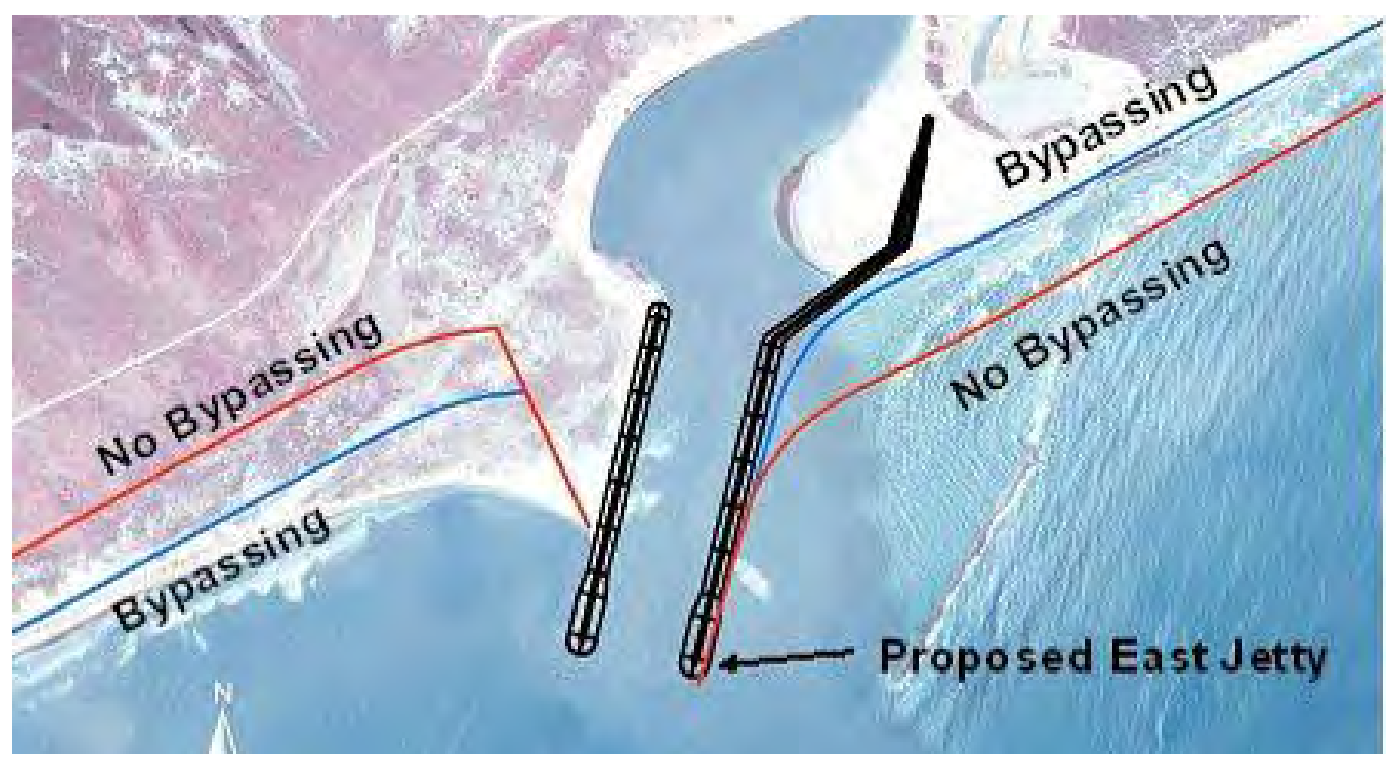

Figure 20. Shoreline position after 10 years of WIS waves from 1990 to 1999 with proposed jetty design, with and without sediment bypassing from up-drift to down-drift beaches (photograph May 2006). 


\section{Summary}

Analysis of dredging volume at the MCR indicates the average annual volume removal is 556,000 cu yd/year, which includes some fine sediment believed to originate from the CRNC bottom and GIWW. Approximately $367,000 \mathrm{cu}$ yd/year of this total originates from the littoral zone, and the remainder, 189,000 cu yd/year, is supplied by the CRNC and GIWW. An improvement in self-scouring potential, such as considered through construction of a new east jetty, would increase the speed of the current through the channel and tend to flush fine-grained material to the offshore.

Shoreline response was modeled with GENESIS, and verification of the model was based on the dredging records and longshore sand transport rates from previous studies. Estimated rates for the initial stage of calibration were a westward transport rate of approximately $425,000 \mathrm{cu} \mathrm{yd} /$ year, a net transport rate of $200,000 \mathrm{cu} \mathrm{yd} /$ year directed to the west, and a gross transport rate of approximately 600,000 cu yd/year.

GENESIS was applied to the east and west shorelines in a 20-year simulation based on WIS wave hindcast information. Calculated transport rates on the east and west shorelines were similar to the estimated target rates. The east shoreline gross rate is on the order of 650,000 cu yd/year, the net rate is approximately $210,000 \mathrm{cu} y d /$ year west, and the westward transport rate is approximately $430,000 \mathrm{cu}$ yd/year. The calculated gross rate at the western boundary of the west shoreline is approximately $650,000 \mathrm{cu} \mathrm{yd} /$ year, with a net rate of 190,000 cu yd/year and a westward transport rate of 420,000 cu yd/year. The annual volume of sand bypassing the east and west jetties over a 20 -year simulation was $74,000 \mathrm{cu}$ yd and 12,000 cu yd, respectively, if the sand is not mechanically bypassed from the east to the west beach.

Investigation of the response of the shoreline to the proposed east jetty indicates that the Galveston District practice of bypassing sand from the west beach is necessary to maintain the respective shoreline positions. Without sand bypassing, simulations indicate that the proposed east jetty would be impounded, and sand would bypass naturally into the MCR. GENESIS results also indicated that erosion of the west beach could lead to flanking of the west jetty without bypassed sand placed on the west beach to maintain shoreline position or historic recession rate. 
If the new east jetty is constructed, it is recommended that mechanical or hydraulic bypassing be performed according to monitoring of the east and west beaches and the navigation channel. The accretion fillet that will form next to the new east jetty should not be allowed to grow too close to the gulfward end of the jetty. If so, the accumulated sand would tend to move around the east jetty to create a jetty tip shoal that would enter the channel from the east. Bypassing of material might best be done through excavation of the fillet and pumping the dredged material to a location sufficiently far to the west on the west beach that it would not readily be transported to the entrance under reversals of wave direction and longshore transport. Material dredged from the navigation channel should similarly be bypassed to the west. 


\section{Tidal Inlet Processes}

This chapter investigates alternative jetty and navigation channel improvements at the MCR from the perspective of tidal inlet processes. The jetty improvement considers a new 2,000-ft-long east jetty issuing from the existing sediment-training structure and is designed to reduce sediment encroachment from the Gulf of Mexico into the CRNC. The alternative navigation channel designs considered are a 150 -ft- and a 200-ft-wide, 13-ft-deep channel, relative to mean tide level (MTL), to maximize the flow rate and increase self-scouring of the inlet entrance.

The numerical model grid for the hydrodynamics of the multiple-inlet system includes provision for examining two proposed inlets, one connecting East Matagorda Bay to the CRNC and the other connecting Matagorda Bay to the CRNC. If implemented, the resultant system would consist of three inlets in the near field (MCR and two artificial inlets) and three inlets to the Gulf of Mexico in the far (regional) field-Mitchell's Cut into East Matagorda Bay, and Pass Cavallo and the Matagorda Ship Channel into Matagorda Bay. At present, the flow system that connects with the MCR is separated from Matagorda Bay, the main stream of the Colorado River, and from the westward section of the GIWW by a pair of boat locks.

\section{Regional and local models}

A regional circulation model (Brown et al. 2003) and the Coastal Modeling System (CMS) as the project-level or local modeling system (Militello et al. 2004; Mase et al. 2005; Buttolph et al. 2006; Lin et al. 2006) were applied in this study. The regional circulation model simultaneously simulated the circulation and water level for both East Matagorda Bay and Matagorda Bay, including the MCR. The CMS calculated nearshore waves, circulation pattern, sand transport rate, and morphology change at the MCR. The regional circulation model provided regionally correct water-level boundary conditions to drive the CMS, accounting for tide, wind, and river discharges. 
Figure 21 shows the regional circulation model grid for the multiple-inlet flow system. The bathymetry data serving as input to generate the grid were obtained from multiple sources:

1. NOAA nautical charts.

2. Bathymetry survey of the East Matagorda Bay by Kraus and Militello (1996).

3. Bathymetry survey of the MCR and CRNC by CHL (December 2006).

4. Bathymetry survey of Mitchell's Cut by CHL (December 2001).

5. Bathymetry survey of Matagonda Bay near and around the diversion channel and the junction of CR and GIWW by CHL (July 2001).

6. Cross sections of the MCR and GIWW by the Galveston District (October 1999 to J anuary 2004).

7. Digital Nautical Chart (DNC) (http://www.nga.mil/portal/site/dnc) produced by National Geospatial Intelligence Agency (NGA).

Recent aerial photographs taken periodically at the MCR, Mitchell's Cut, and MSC furnished additional information on the shoreline and configuration of the jetties.

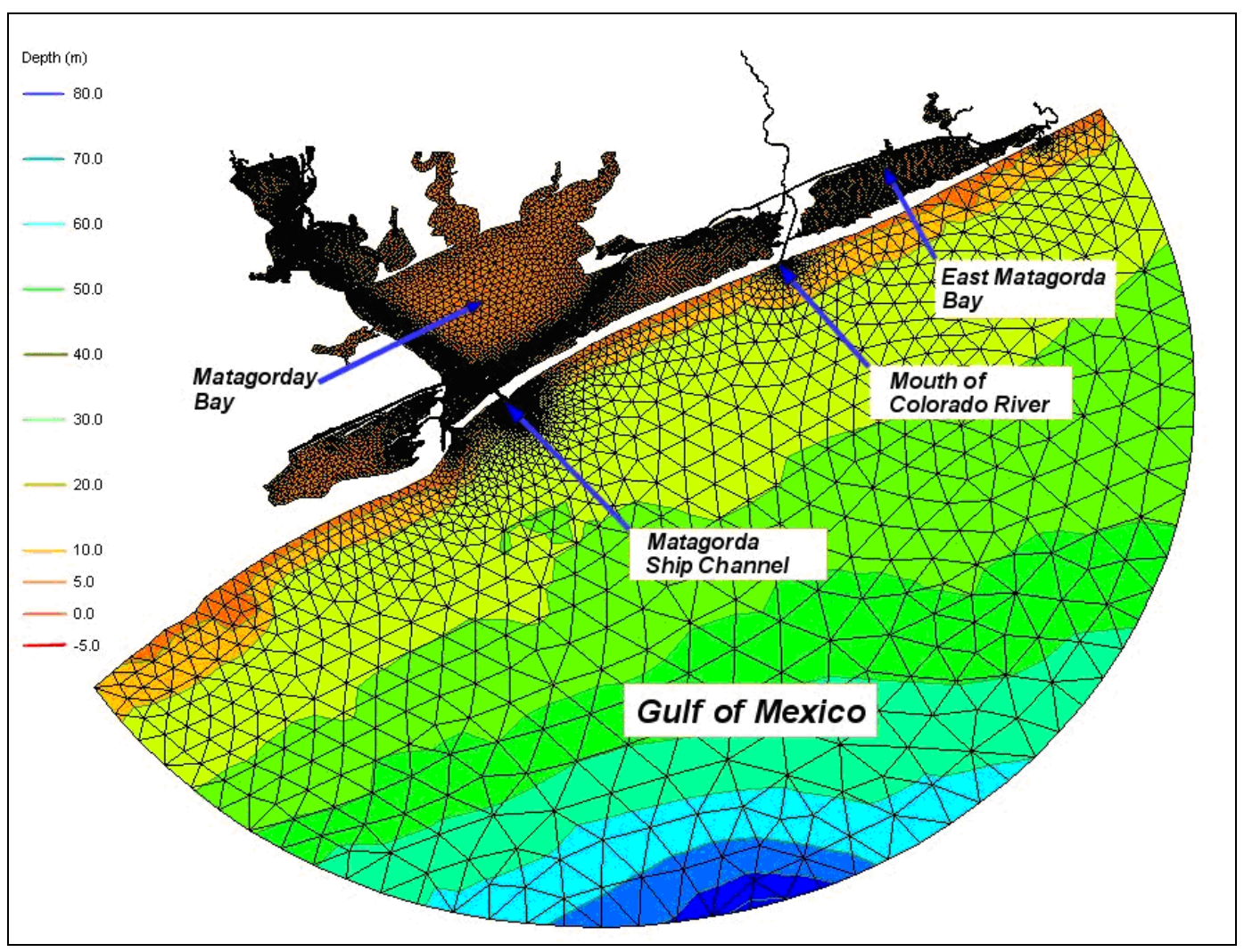

Figure 21. Regional circulation model grid. 
The numerical grid includes provision for representing two proposed inlets: the SW Corner Cut connecting East Matagorda Bay to the CRNC, and Parkers Cut connecting Matagorda Bay to the CRNC. The SW Corner Cut is a 2-mile-long channel, $260 \mathrm{ft}$ wide (100 ft wide at the bottom) and $5 \mathrm{ft}$ deep with respect to MTL, which runs southwest from the western end of East Matagorda Bay to intersect CRNC about 2 miles upstream of the Gulf of Mexico (Kraus and Militello 1996, 1999). Parkers Cut would connect Matagorda Bay at its eastern end and the CRNC approximately 1.9 mile upstream of the Gulf of Mexico. Parkers Cut was represented as 1 mile long, $260 \mathrm{ft}$ wide, and $5 \mathrm{ft}$ deep. Figure 22 shows the detail of the model grid in the MCR and CRNC area including the junction of the CR and GIWW, the diversion channel and CRNC, the proposed SW Corner Cut and Parkers Cut, and the two GIWW boat locks bracketing the CR.

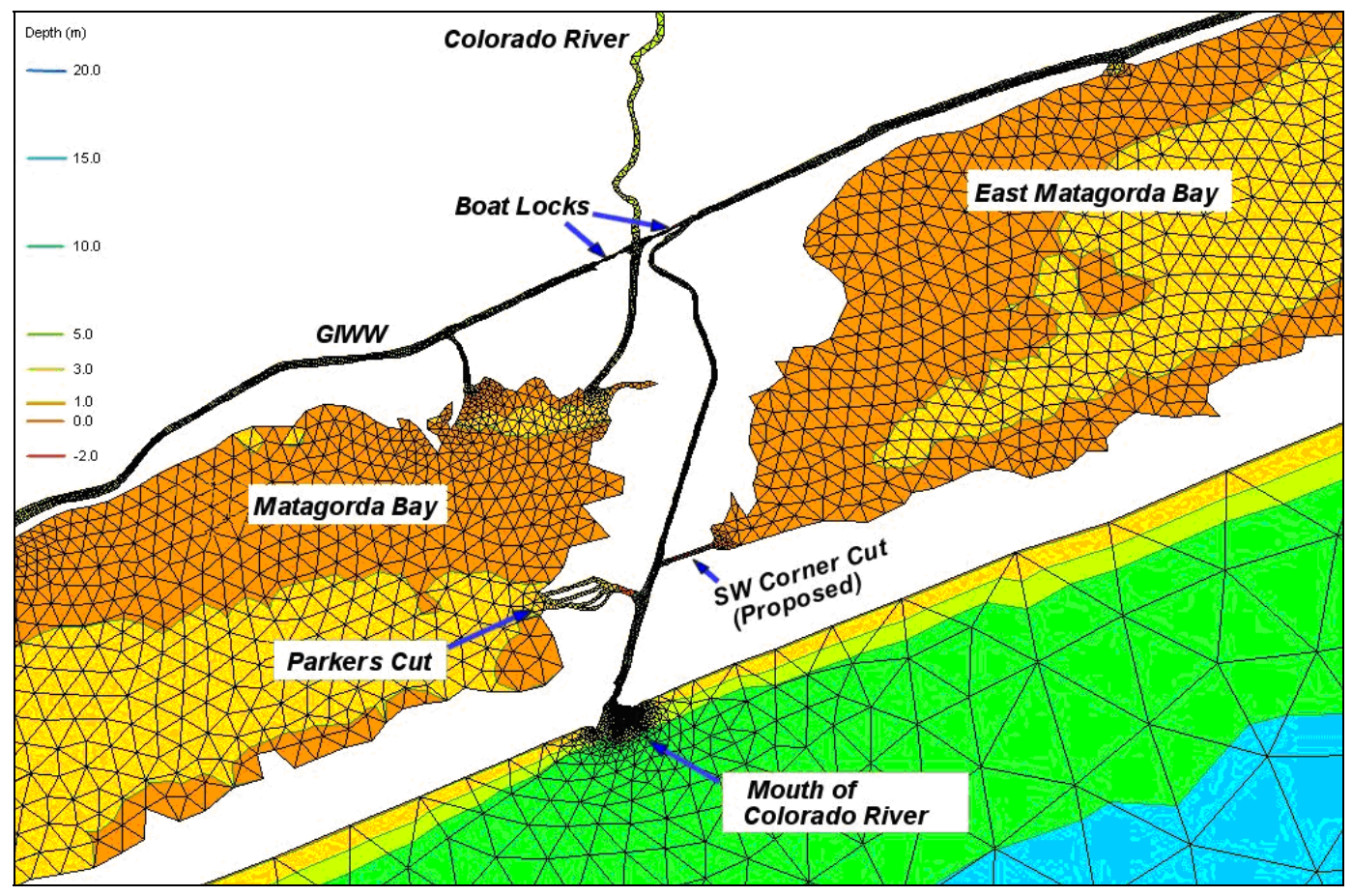

Figure 22. Regional circulation model grid at MCR.

Local morphology change at the MCR was estimated by the CMS. The effect of waves on the circulation and sediment transport is included in the calculation (Lin et al. 2003). In this application, the CMS covers a rectangular area of 2.5 mile $\times 2.7$ mile with a constant cell size of $33 \mathrm{ft} \times 33 \mathrm{ft}$. Figure 23 shows the CMS project-level model grid domain. 


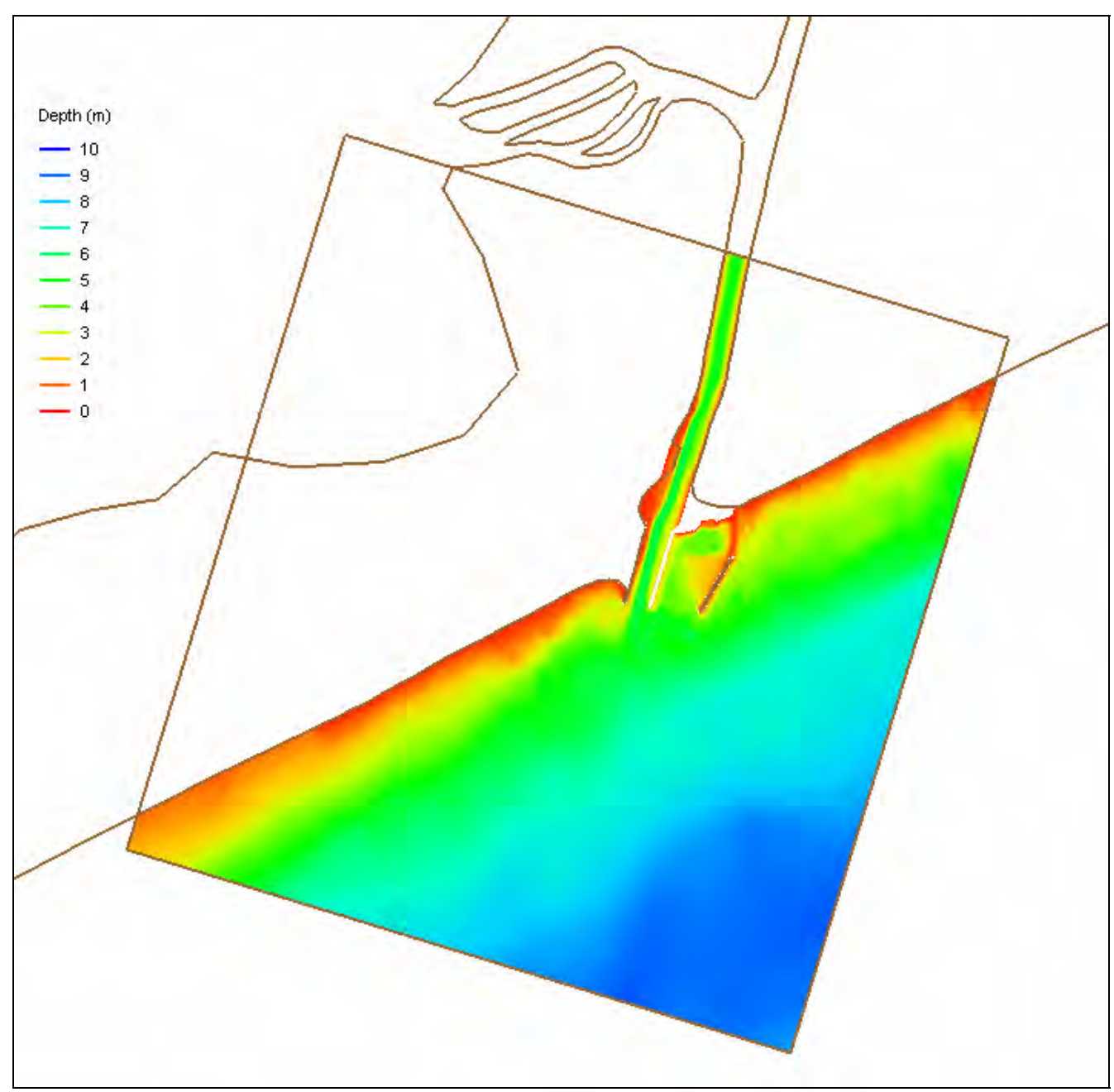

Figure 23. CMS numerical grid domain.

\section{Boundary conditions}

The regional circulation model was driven by wind forcing over the numerical grid domain and the tidal fluctuation of water surface elevation given at grid edges in the Gulf of Mexico. Inflows of Colorado River, Lavaca River, Caney Creek, and Live Oak Bayou were also included.

Wind plays a major role in controlling the water level and circulation in the shallow coastal waters of Texas. The prevalent southeasterly summer wind and intermittent winter northerly wind fronts characterize the wind forcing on the hydrodynamics of the East Matagorda Bay and Matagorda Bay. The surface wind data collected by the Texas Water Development Board (TWDB) at the East Matagorda, Old Gulf Cut (28042'48"N and $95^{\circ} 53^{\prime} 18^{\prime \prime} \mathrm{W}$ ) tide stations served as the wind forcing to the model. 
Water level measured in the Gulf of Mexico can capture the meteorological tide produced by wind and pressure gradients as well as the astronomical tide. In the present study, water surface elevations measured at the

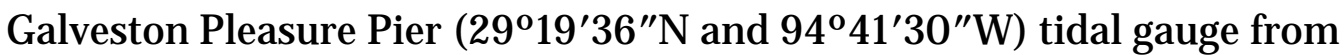
the Texas Coastal Ocean Observation Network were supplied as the Gulf of Mexico boundary conditions (http://dnr.cbi.tamucc.edu).

Discharges from the Colorado River, Lavaca River, Caney Creek, and Live Oak Bayou were included in the simulation of the hydrodynamics. Daily average river discharge information for the Colorado River is available from the U.S. Geological Survey (USGS) National Water Information System. The flow for Lavaca River was approximated as one-tenth of the Lower Colorado River. Discharges for Caney Creek and Oak Bayou were approximated as one-tenth (proportion of the watershed area) of the river discharge of the nearby San Bernard River. River discharge information for both the Colorado River and the San Bernard River is available at http://water.usgs.gov/data.html. Daily discharges for the Colorado River and San Bernard River in 1999 are shown in Figure 24, indicating strong seasonal variation.

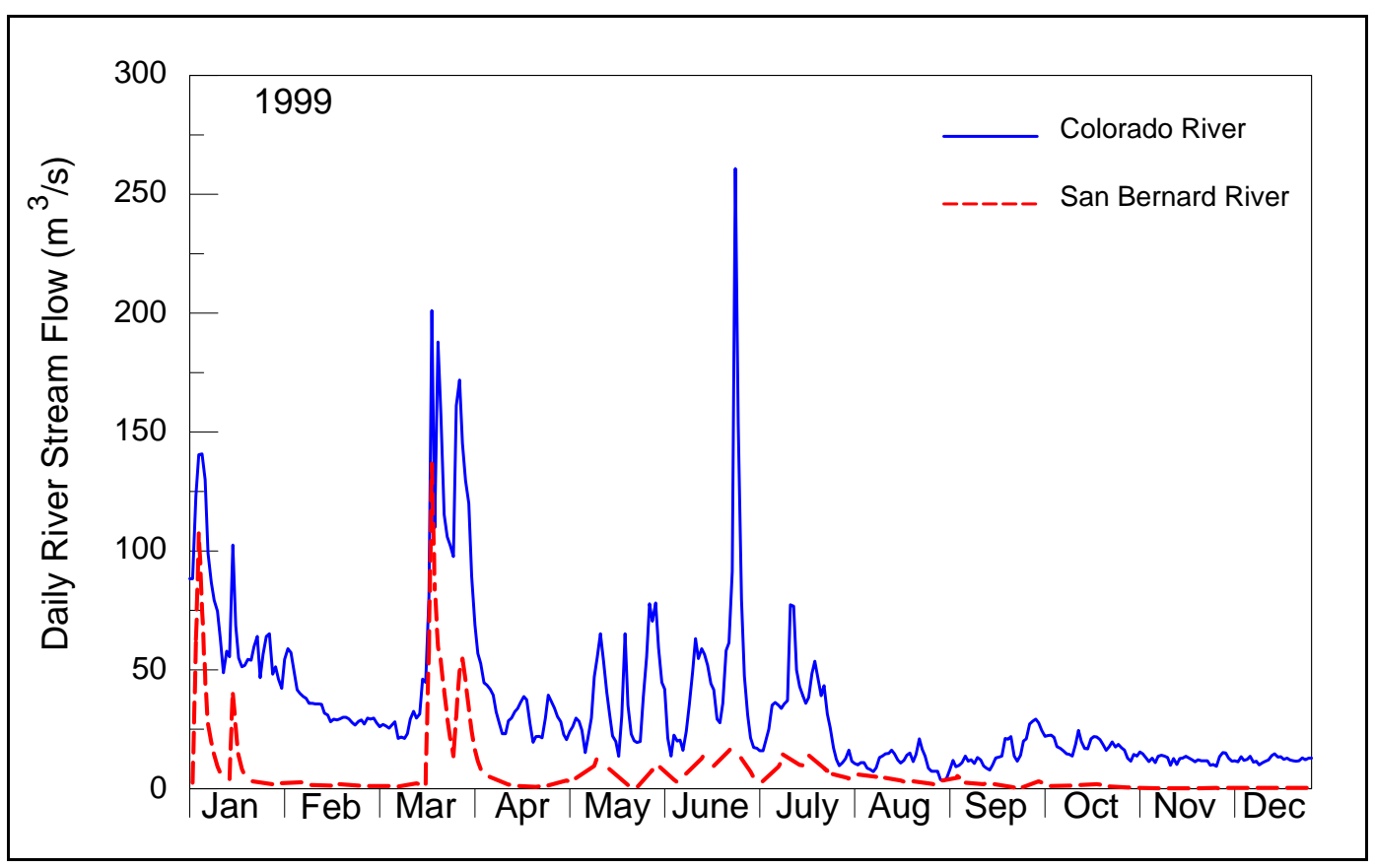

Figure 24. Discharges at Colorado River and San Bernard River, 1999.

Wave information collected from Buoy 42019 maintained by the National Data Buoy Center (NDBC) was input to the CMS. Table 7 presents the NDBC Buoy 42019 station information (http://www.ndbc.noaa.gov). Table 8 
presents the seasonal and annual mean/maximum significant wave heights, spectral mean wave periods, and spectral mean directions at Buoy 42019 for the period 1990-1999. The mean wave direction is computed in the meteorological convention, i.e., 0 deg corresponding to waves incident from the north, and 90 deg corresponding to waves incident from the east.

Table 7. NDBC Buoy 42019 information.

\begin{tabular}{|l|l|}
\hline ID & 42019 \\
\hline Latitude & $27^{\circ} 54^{\prime} 36^{\prime \prime} \mathrm{N}$ \\
\hline Longitude & $95^{\circ} 21^{\prime} 36^{\prime \prime} \mathrm{W}$ \\
\hline Depth, $\mathrm{m}$ & 82 \\
\hline Period & May 1990 - December 1999 \\
\hline Directional wave measurements & February 1997 - December 1999 \\
\hline
\end{tabular}

Table 8. Buoy 42019 wave statistics, 1990-1999.

\begin{tabular}{|l|c|c|c|c|c|}
\hline Parameter & Jan-Mar & Apr-Jun & Jul-Sep & Oct-Dec & Annual \\
\hline $\begin{array}{l}\text { Mean significant } \\
\text { wave height, } \mathrm{m}\end{array}$ & 1.46 & 1.21 & 0.90 & 1.47 & 1.26 \\
\hline $\begin{array}{l}\text { Maximum } \\
\text { significant height, } \mathrm{m}\end{array}$ & 5.80 & 4.30 & 5.40 & 5.45 & 5.80 \\
\hline Mean period, sec & 6.8 & 6.5 & 6.1 & 6.9 & 6.6 \\
\hline $\begin{array}{l}\text { Mean direction, deg } \\
(1997-1999)\end{array}$ & 113 & 136 & 140 & 100 & 124 \\
\hline
\end{tabular}

Incident wave conditions were determined by the transformation of directional buoy spectra to the wave model offshore boundary. The nominal water depth at the buoy location is $82 \mathrm{~m}$, and the mean depth along the wave model grid offshore boundary is $8 \mathrm{~m}$. The wave transformation computes wave refraction and shoaling under the assumption of parallel shore and depth contours.

Wave direction measurements at Buoy 42019 for the interval 1997- 1999 indicate that the spectral mean wave direction is $124 \mathrm{deg}$. The mean wave direction is about 34 deg east of the local shore-normal, which is approximately 158 deg at the MCR. Because the majority of waves approach the coast from the direction between east and southeast, the net longshore sediment transport is expected to be to the west. The westward sediment transport direction agrees with the general littoral sediment transport direction observed at the MCR, as discussed in Chapters 1 and 2. 
Figure 25 compares the time series of the significant height, peak period, and spectral peak mean wave direction at the buoy location and at the wave model offshore boundary for J anuary 2004. The comparison shows that wave heights are reduced significantly from the buoy location to the wave model offshore boundary. Waves tend to turn toward the shore as a result of wave refraction, whereas spectral peak periods appear to change only slightly in the transformation. Both the calculated wave radiation stresses and basic wave information serve as input to the CMS for calculation of the wave-induced circulation and sediment transport, respectively.
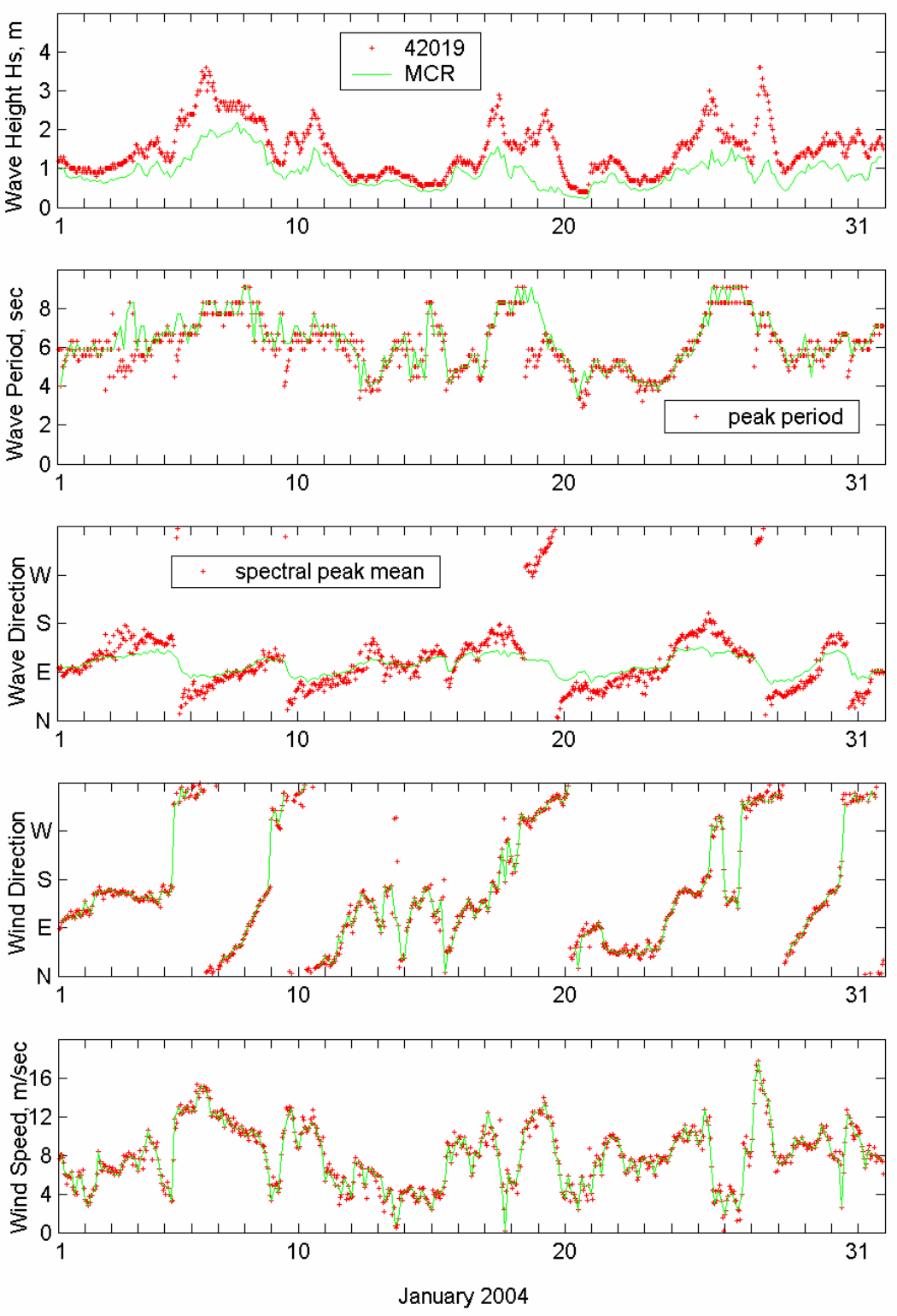

Figure 25. Time series of measured wind wave data at Buoy 42019 and by transformation to wave model offshore boundary, MCR. 


\section{Numerical simulation of alternatives}

Alternatives are (0) existing condition, (1) 2,000-ft new east jetty connecting to and seaward of the present training structure and 150 -ft-wide navigation channel at the MCR, (2) new east jetty and 200-ft-wide navigation channel, (3) opening the SW Corner Cut with new east jetty and a 150-ft-wide channel, (4) opening the SW Corner Cut with new east jetty and a 200-ft-wide channel, (5) opening Parkers Cut with new east jetty and 150 -ft-wide channel, and (6) opening Parkers Cut with new east jetty and a 200-ft-wide channel. In Alts 1 to 6, the new east jetty is oriented approximately parallel to the west jetty, and the distance between the seaward ends of the new east jetty and west jetty is approximately $500 \mathrm{ft}$. Figures 26 and 27 show the 150- and 200-ft-wide navigation channel configurations, respectively, with the new east jetty. Table 9 summarizes the alternatives.

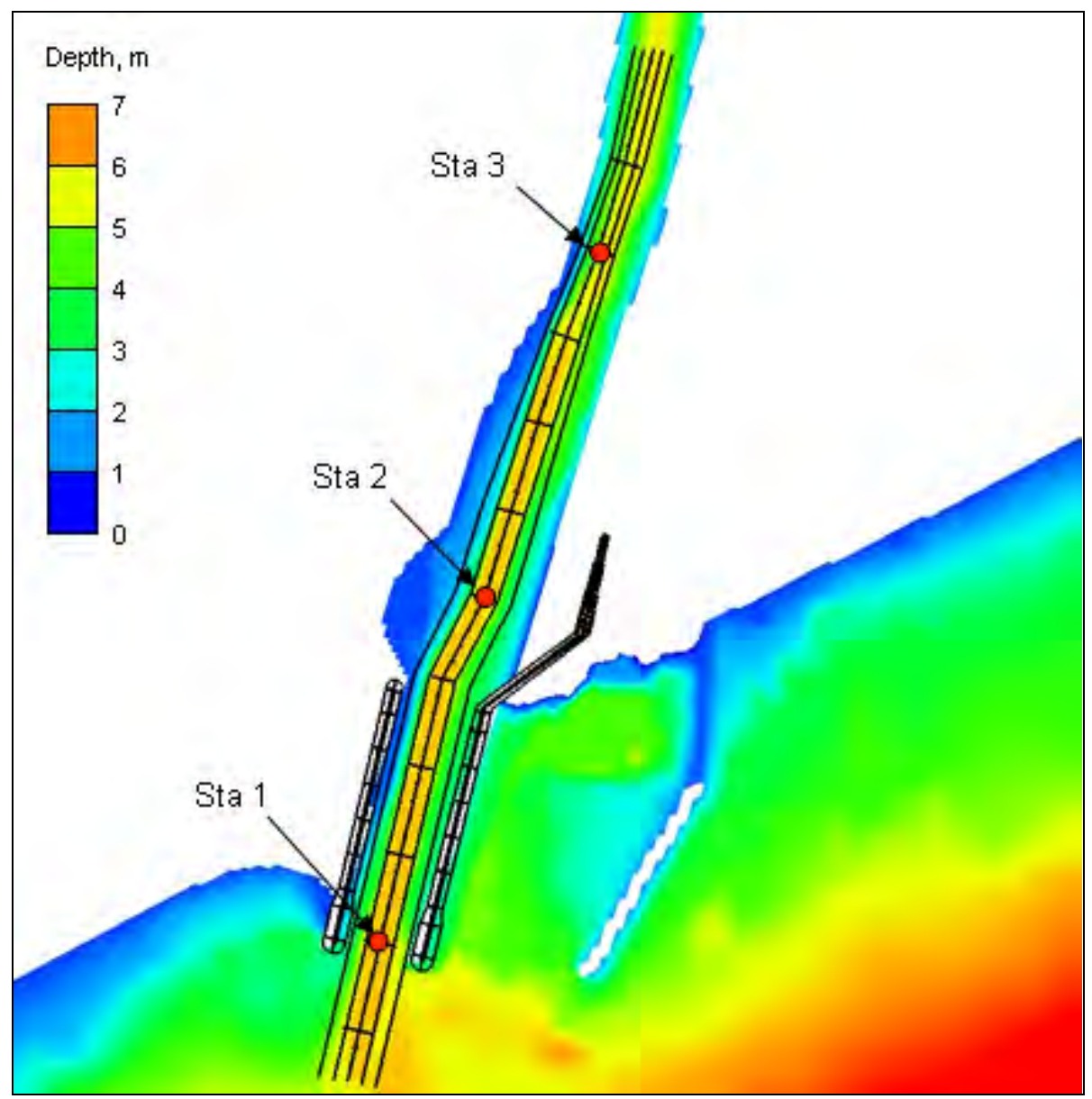

Figure 26. New east jetty and 150-ft-wide channel. 


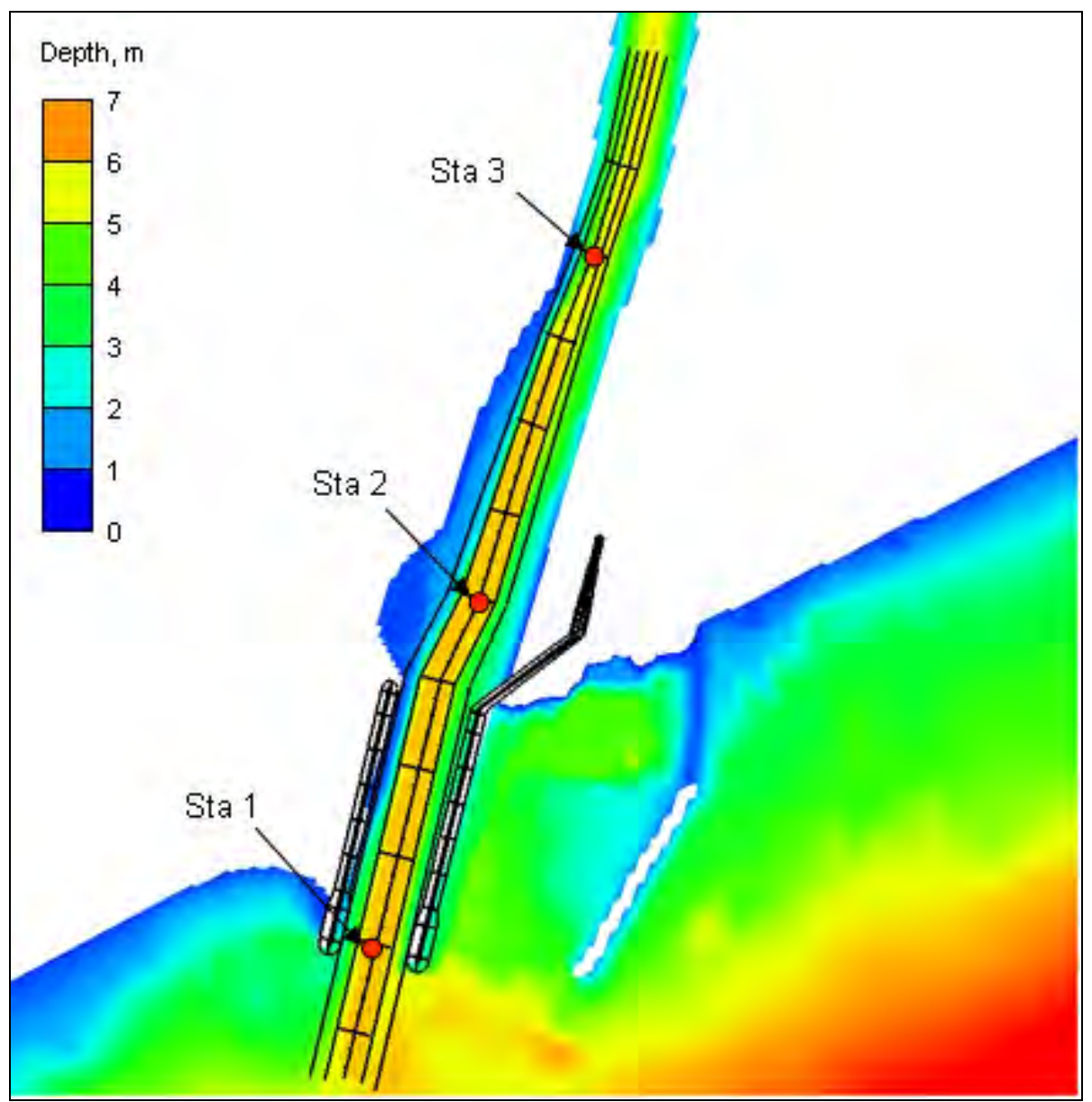

Figure 27. New east jetty and 200-ft-wide channel.

Table 9. Description of alternatives.

\begin{tabular}{|l|l|}
\hline Alternative & Description \\
\hline 0 & Existing condition \\
\hline 1 & New east jetty with 150-ft-wide channel \\
\hline 2 & New east jetty with 200-ft-wide channel \\
\hline 3 & New east jetty with 150-ft-wide channel, SW Cut open \\
\hline 4 & New east jetty with 200-ft-wide channel, SW Cut open \\
\hline 5 & New east jetty with 150-ft-wide channel, Parkers Cut open \\
\hline 6 & New east jetty with 200-ft-wide channel, Parkers Cut open \\
\hline 7 & Same as Alt 1, but with 400 ft between jetties \\
\hline
\end{tabular}

For each alternative, the regional circulation model was run for a typical winter month of J anuary 2004 containing wind fronts and larger waves (Figure 25) and a summer month of August 2004 with weaker wind and smaller waves. The calibration of the regional model for the existing 
condition (Alt 0) is presented in Appendix A. Figure 28 shows the water level data collected in J anuary 2004 from the Bob Hall Pier (Corpus Christi) and Galveston Pleasure Pier gauges. The flow rate and water levels calculated from the regional model then served as boundary conditions to CMS for the hydrodynamics and morphology change calculations at the MCR. A research version of the CMS implicit solution-scheme circulation model was applied to allow large time step for expediting the numerical computation.

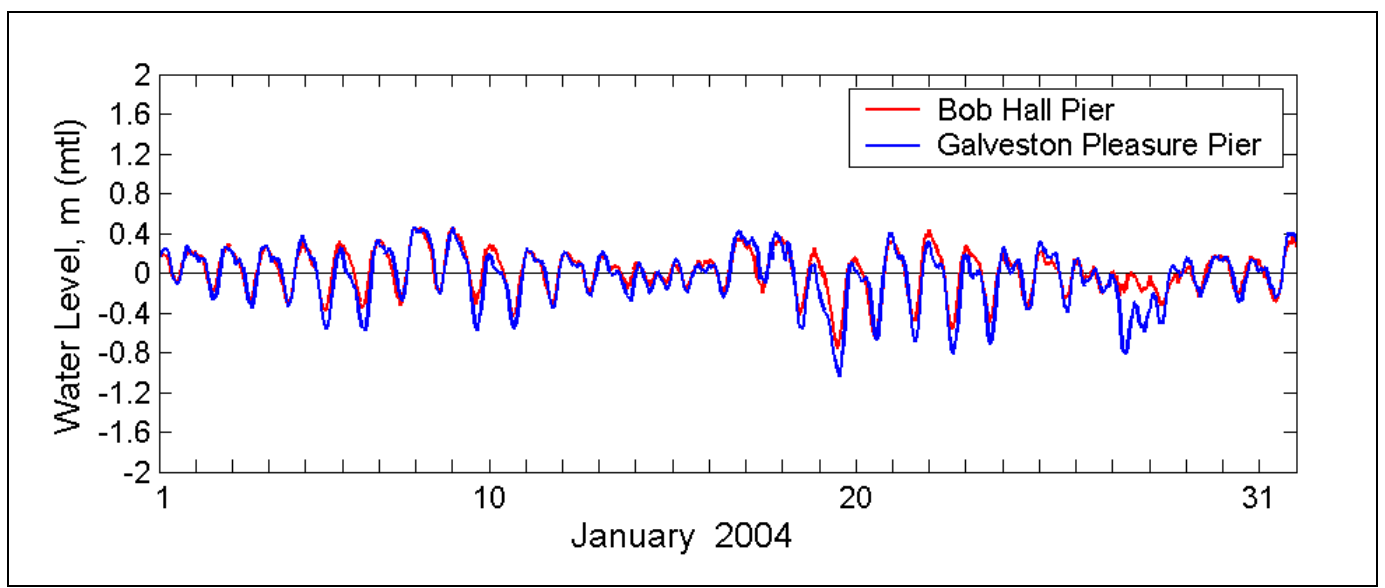

Figure 28. Water level data from Bob Hall Pier and Galveston Pleasure Pier.

Calculations of hydrodynamics, sediment transport, and morphology change were updated at 30-sec, 3-min, and 30-min intervals, respectively. The CMS wave model was run interactively with the circulation model at 3-hr intervals. Figure 29 shows an example of calculated wave field for Alt 1 under the incident wave of 1-m significant height and 7-sec spectral peak period from the southeast. The existing west jetty and its weir were included in the simulations.

Numerical model results of the water level and current calculated at three stations (Figures 26 and 27) are compared for the new east jetty, proposed two cuts, and the existing flow system. The current at the entrance is of direct interest because of its sediment-scouring role in maintaining the channel. Morphology change from these simulations is compared in the channel entrance area. 


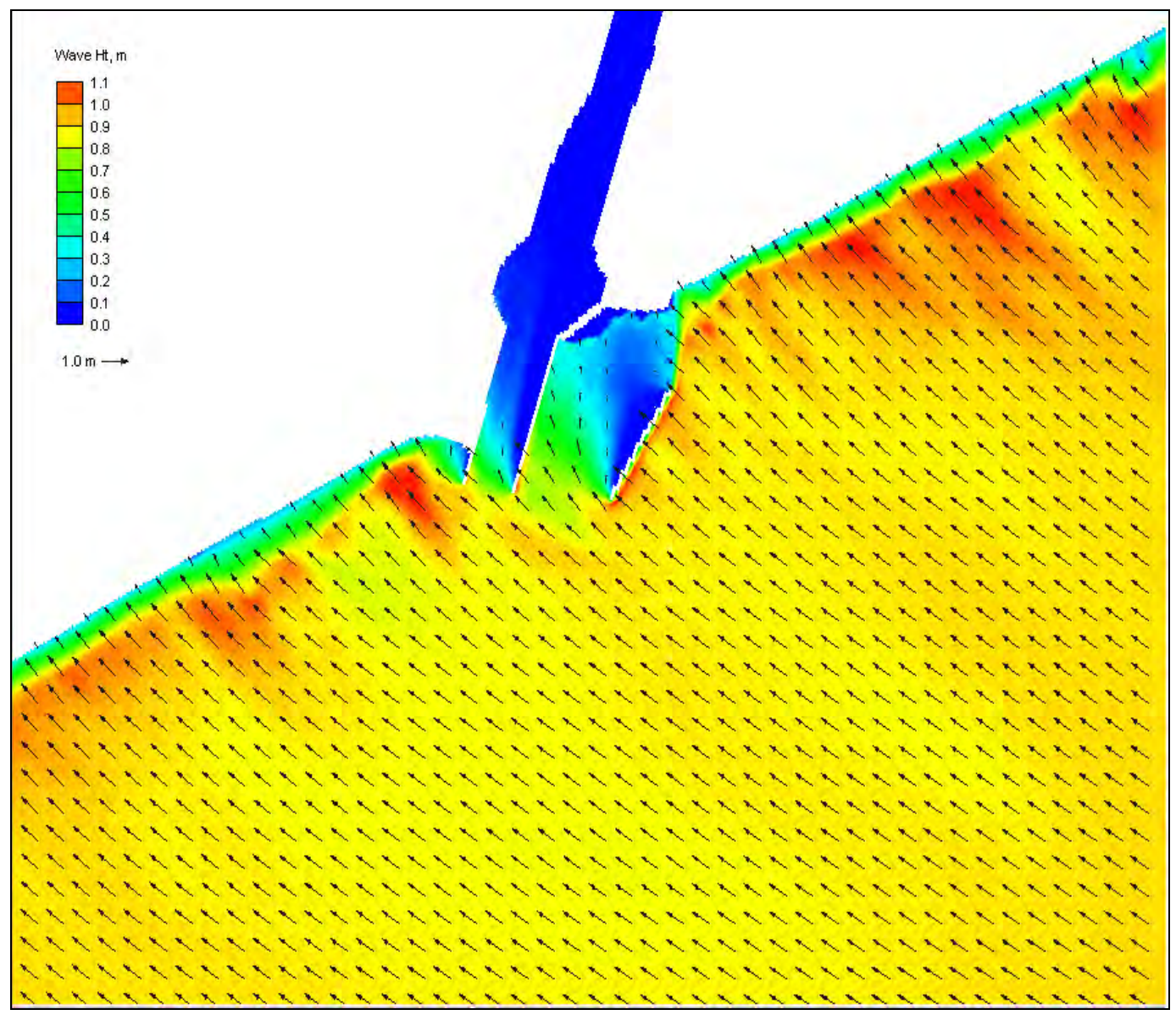

Figure 29. Calculated wave field under incident wave of 1-m significant height and 7-sec spectral period from southeast.

\section{Water level}

Water level was calculated in the regional circulation model and CMS. The contribution of waves to water level is included in the CMS. The regional model does not include the wave and current interaction. Model results from the regional and CMS circulation model are compared at sta 1 , sta 2, and sta 3 (Figures 26 and 27) for 1- $10 \mathrm{~J}$ anuary 2004, a period that contains a spring tidal cycle (FigureA3 in Appendix A). These comparisons indicate that the difference in calculated water levels between the existing system and Alts 1- 6 is negligible at the MCR. Figures 30 to 32 compare water levels from the regional model for the existing and new east jetty conditions with and without opening the SW Corner Cut or Parkers Cut. Figures 33 to 35 compare water levels computed from CMS for the existing system, opening SW Corner Cut, and opening Parkers Cut, respectively. These figures show that water level differences are insignificant at the MCR between 150-ft-wide and 200-ft-wide channels for Alts 0 to 6. 

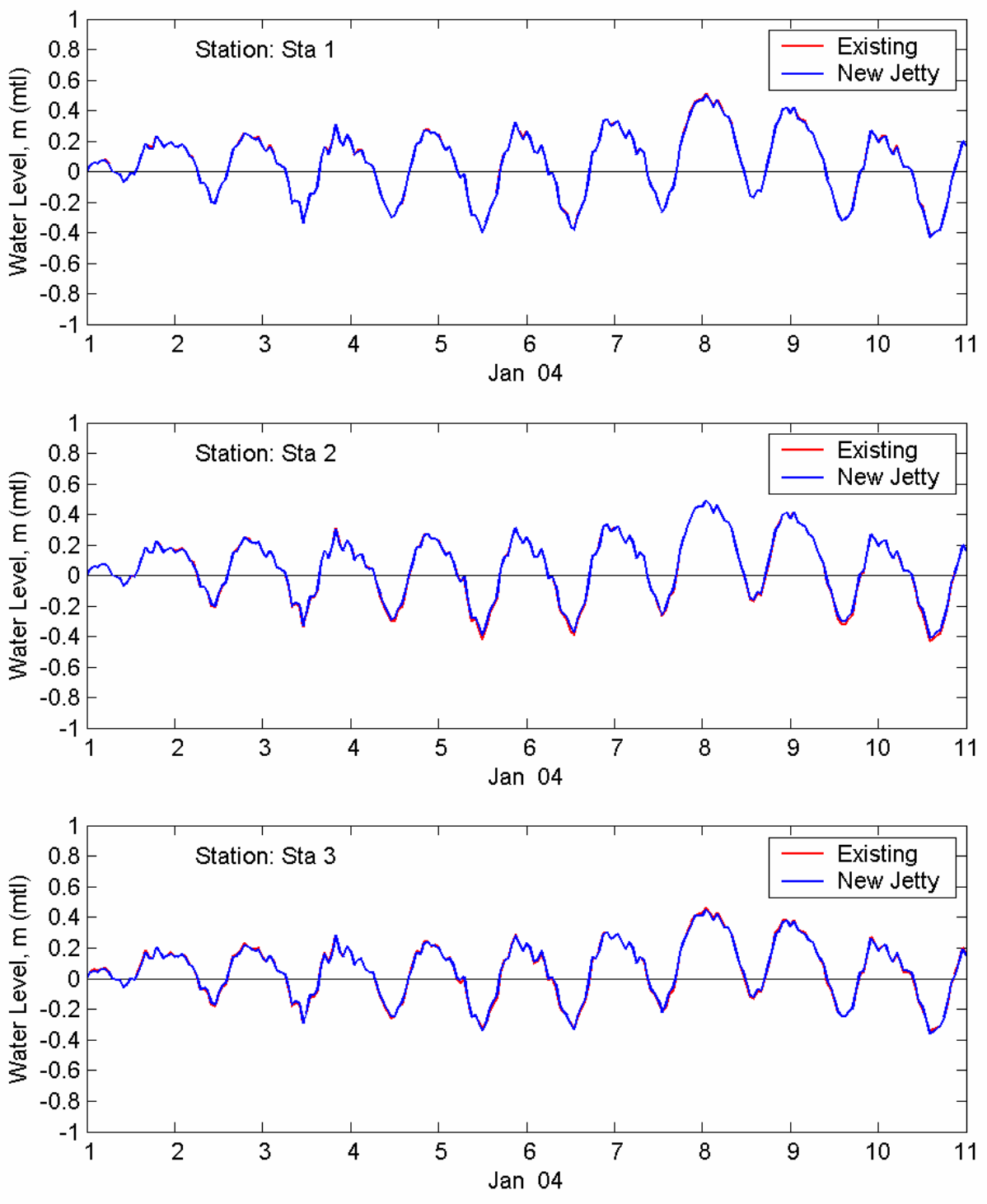

Figure 30. Calculated water levels for existing and new east jetty conditions. 

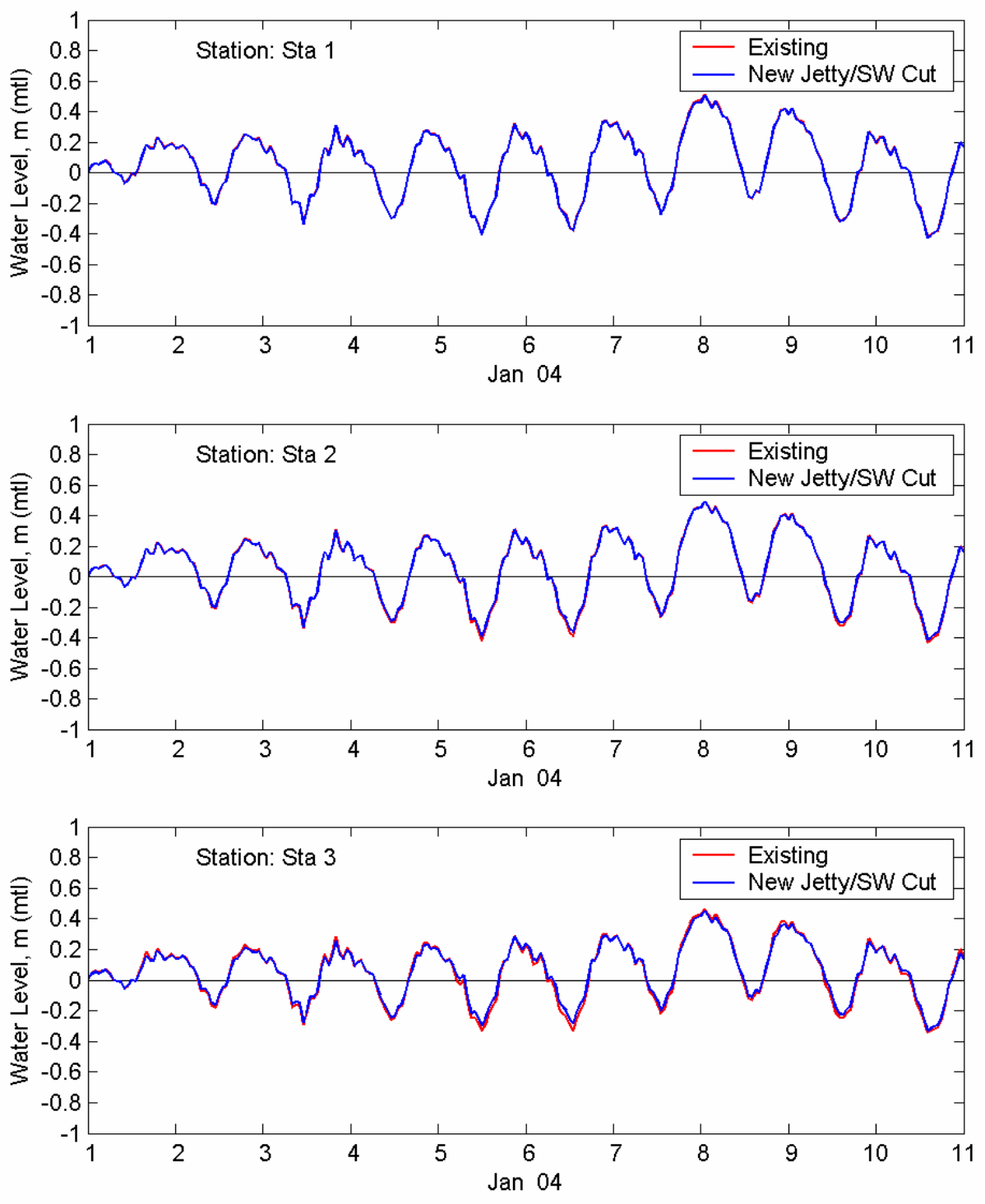

Figure 31. Calculated water levels for existing condition and opening SW Cut. 

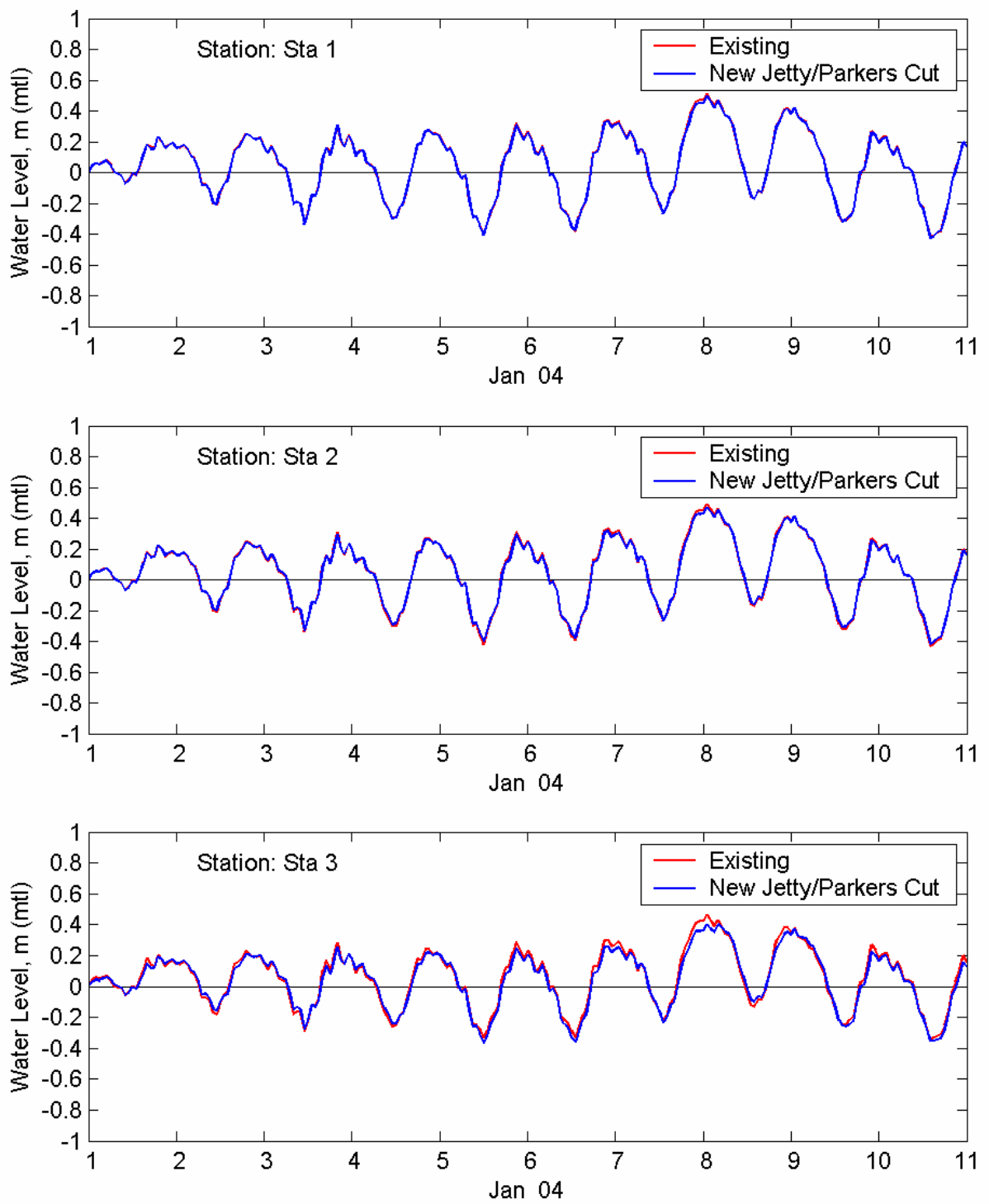

Figure 32. Calculated water levels for existing and opening Parkers Cut. 

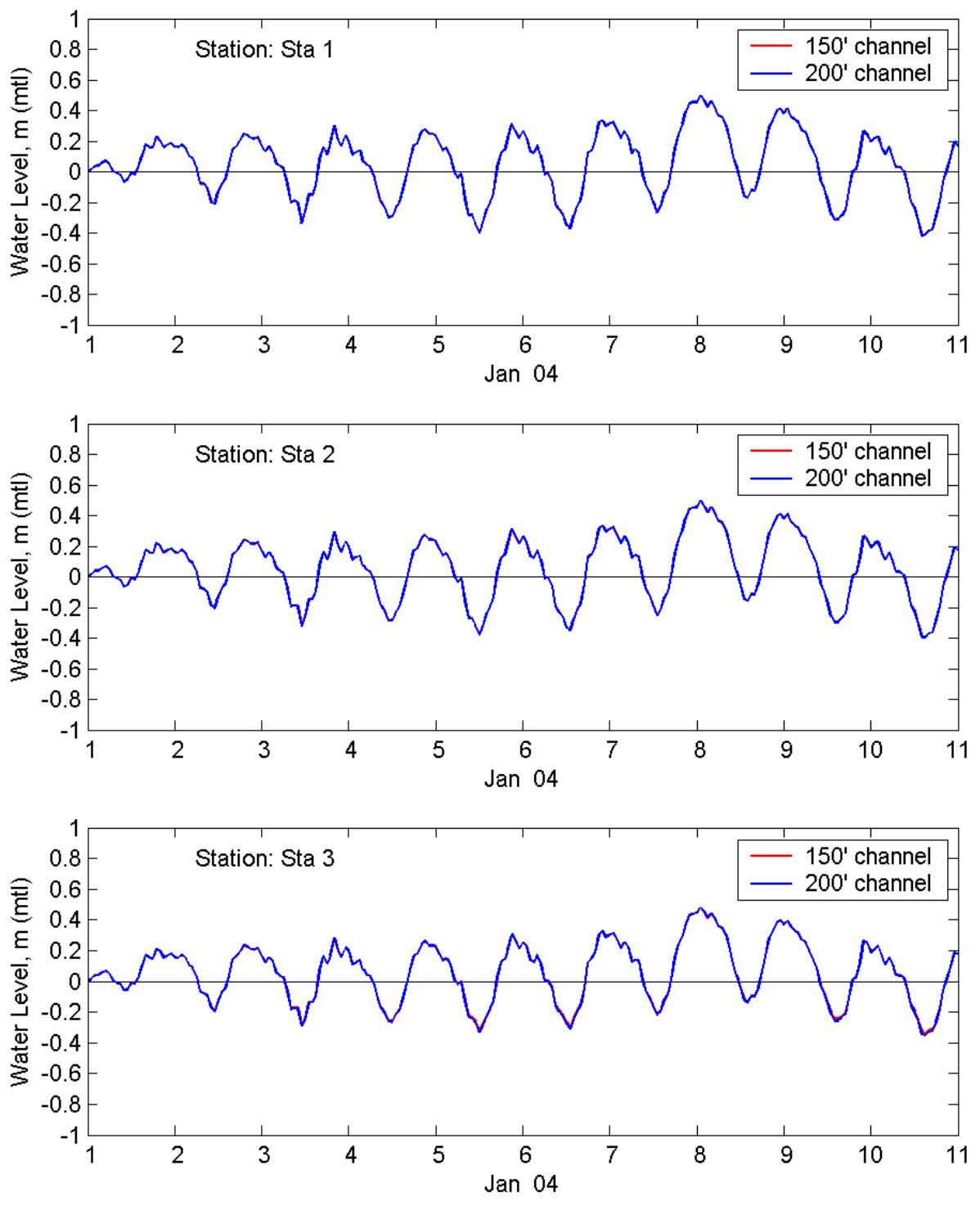

Figure 33. Calculated water levels for Alt 0 with 150- and 200-ft-wide channels. 

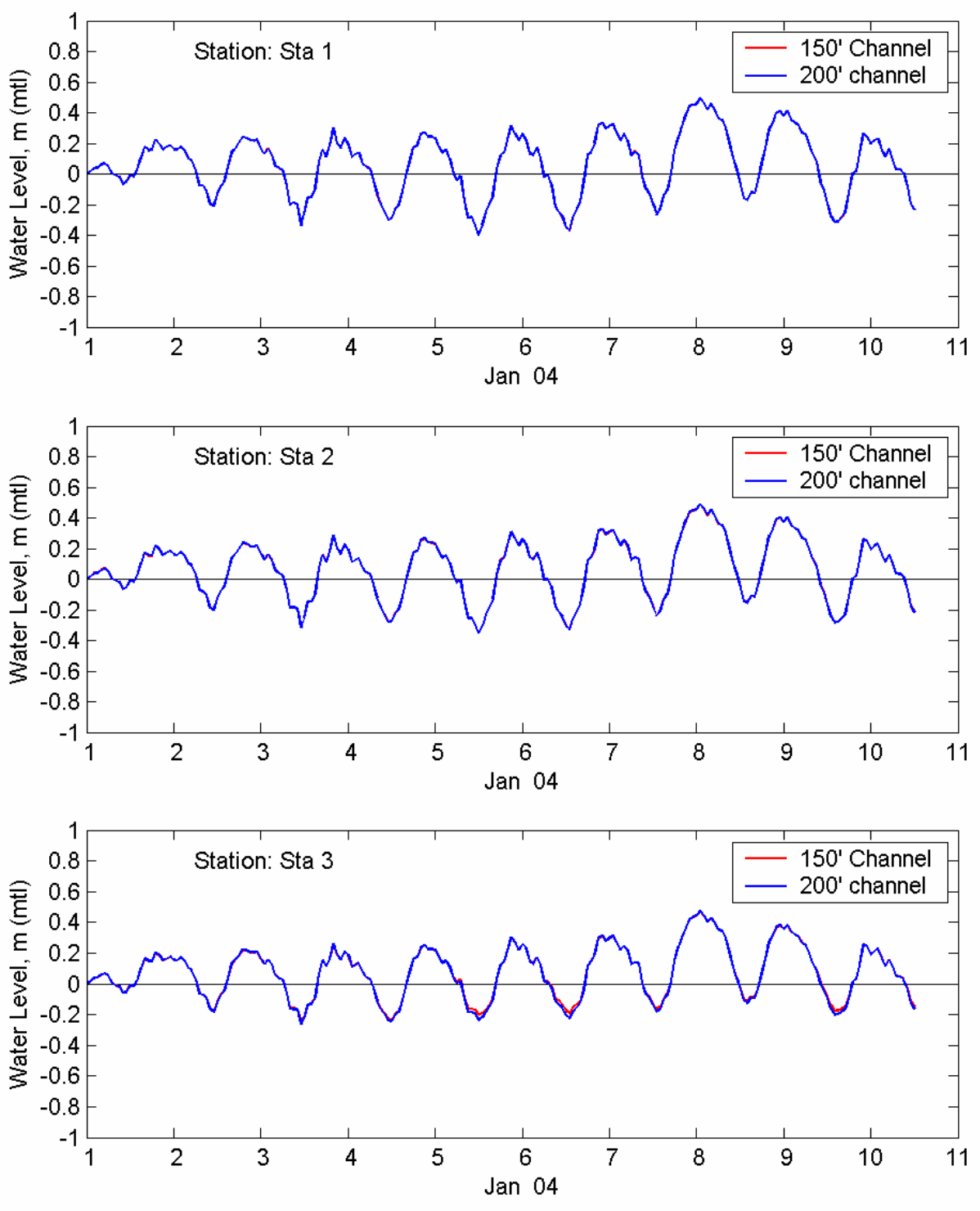

Figure 34. Calculated water levels for opening SW Cut. 

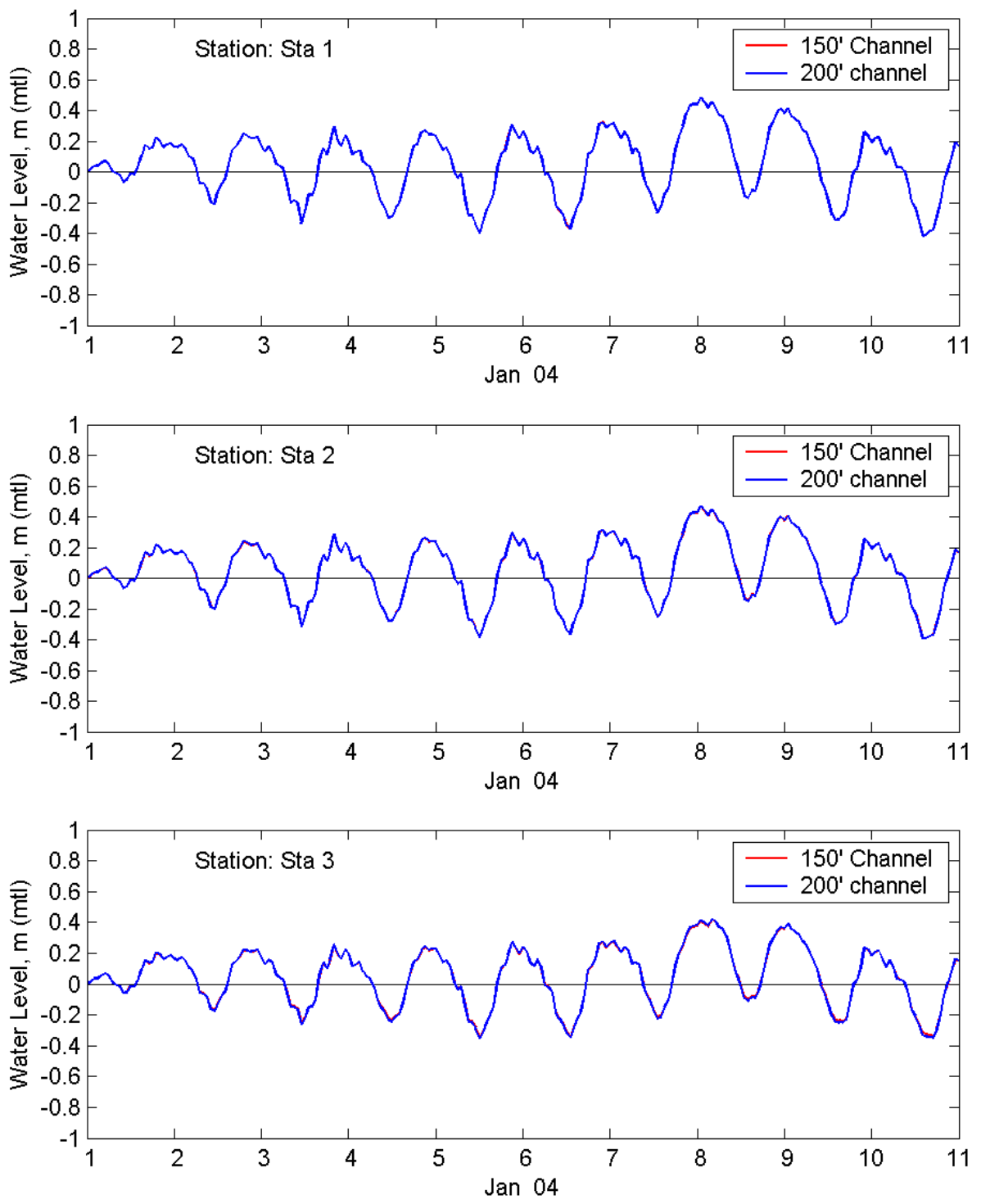

Figure 35. Calculated water levels for opening Parkers Cut.

\section{Current velocity}

Calculated current velocities at the MCR entrance are compared at locations labeled sta 1, sta 2, and sta 3 (Figures 26 and 27). Figures 36 to 38 compare current velocities computed from the CMS for the new east jetty, opening the SW Corner Cut, and opening Parkers Cut, respectively. The current magnitude is stronger at sta 3 in the narrower channel than at sta 1 in the entrance. The current magnitude is stronger in the 150- $\mathrm{ft}$ channel than in the 200-ft channel. For the new east jetty alone with the proposed 150-ft- or 200-ft-wide channel (Alts 1-2), the flow is more uniformly 
distributed between sta 1 and sta 3 . Among the alternatives, the strongest current magnitude is produced by opening the SW Corner Cut and on ebb tide (exiting current). A stronger ebb current will tend to flush sediment from the entrance mouth.

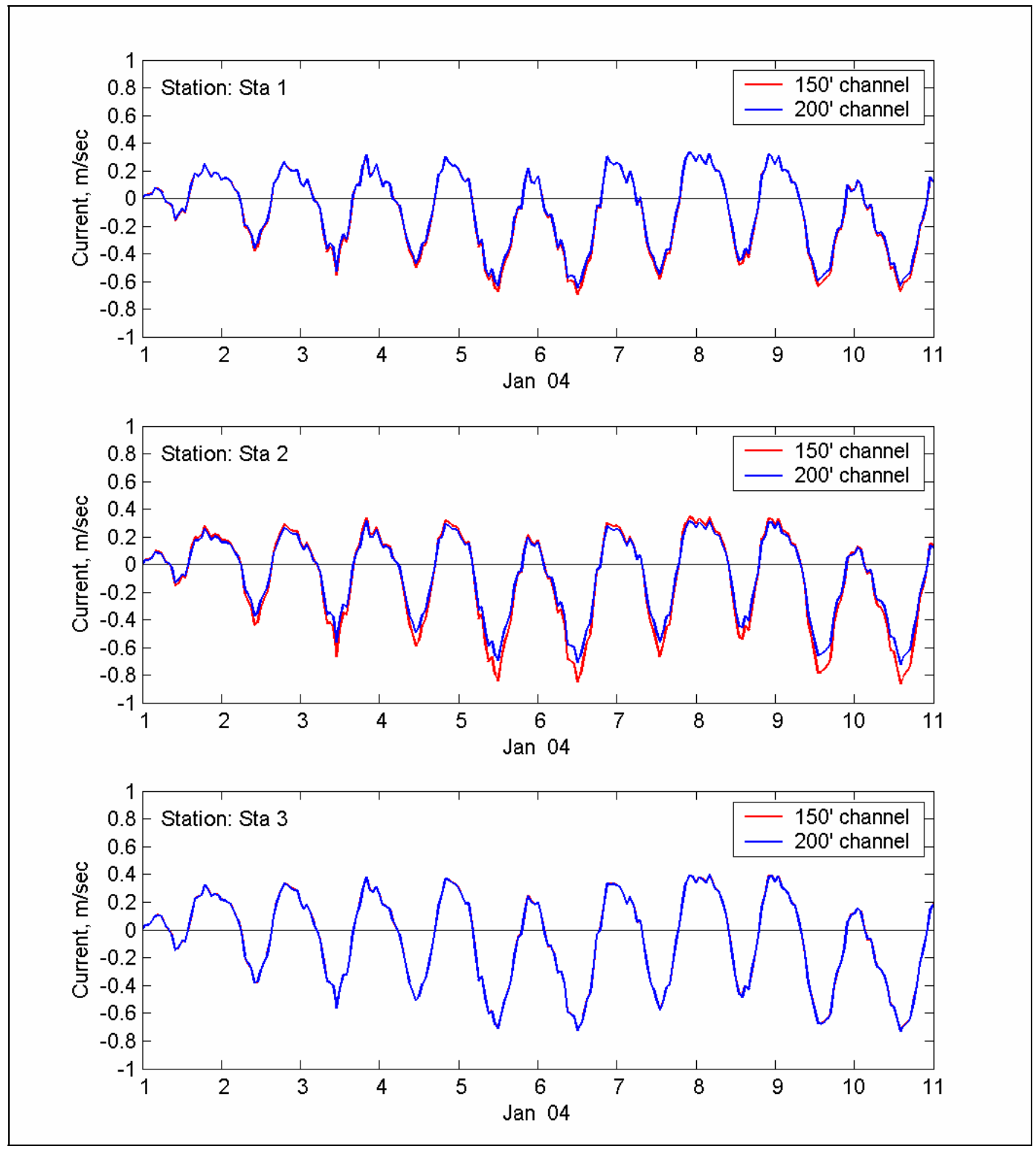

Figure 36. Calculated velocity for new east jetty with $150-\mathrm{ft}$ - and $200-\mathrm{ft}$ - wide channels. 

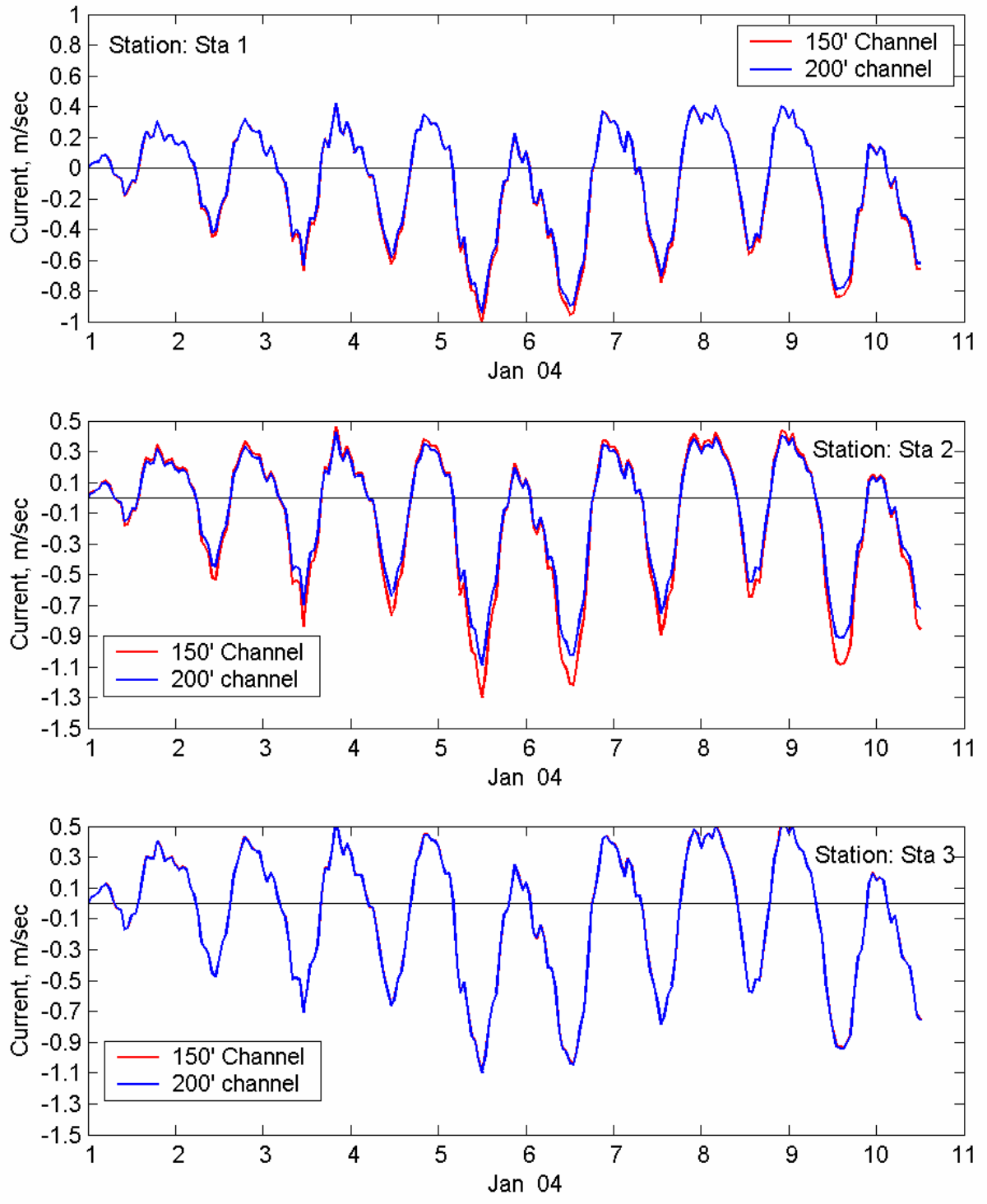

Figure 37. Calculated velocity for opening SW Cut. 

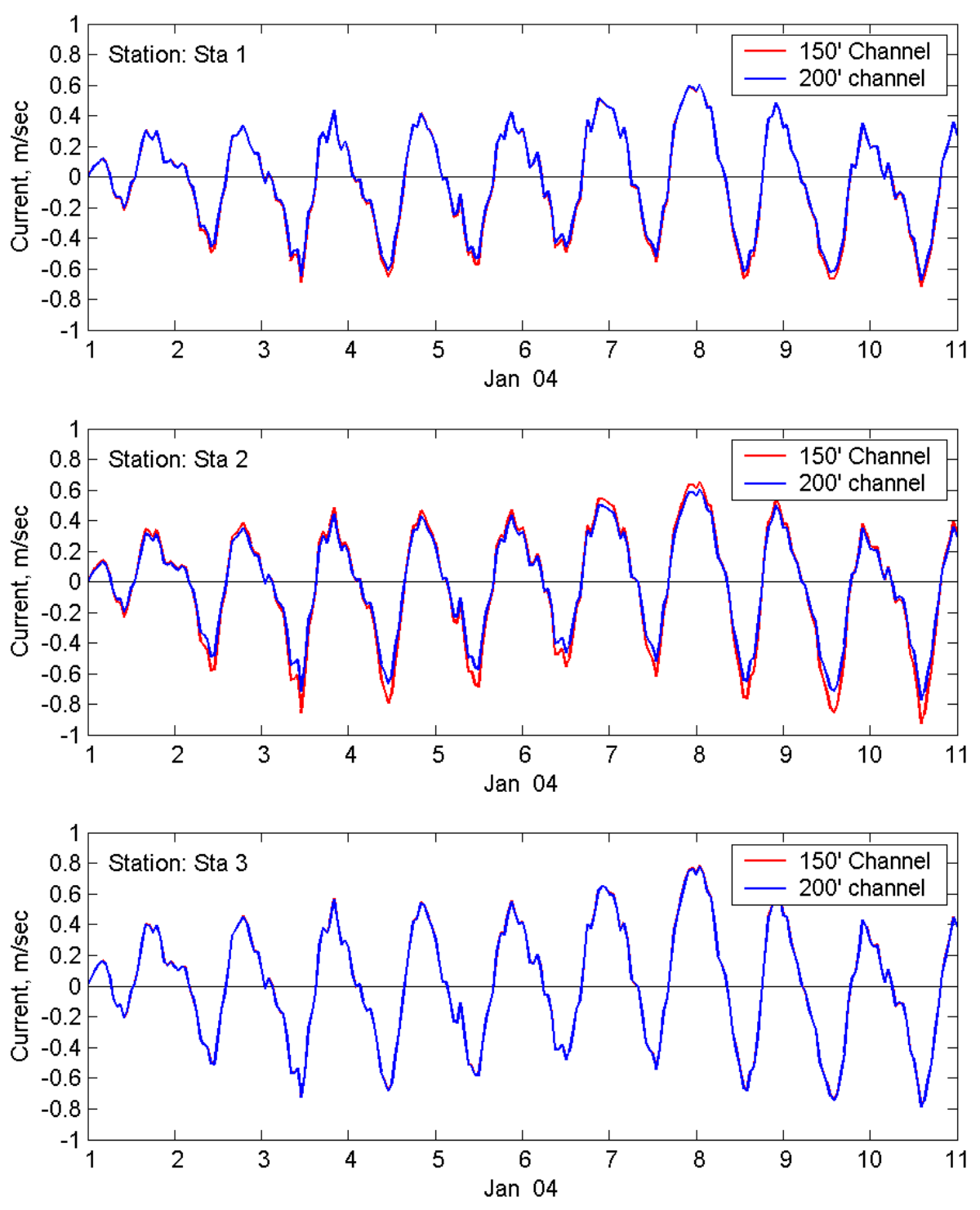

Figure 38. Calculated velocities for opening Parkers Cut.

The flow is stronger in the entrance channel with the new east jetty and opening of the SW Corner Cut or Parkers Cut than for the new east jetty without these internal inlets to the CRNC. With opening of the SW Corner Cut, the flow becomes more ebb biased in the entrance channel and stronger (Kraus and Militello 1996, 1999), for both the 150-ft- and the 200 -ft-wide channels. The ebb current magnitude at sta 1 and sta 2 increases significantly at its peak (Figure 37) as compared with the new jetty without these internal inlets (Figure 36) on some tidal cycles (dependent on wind blowing on East Matagorda Bay). In contrast, with opening Parkers Cut, the flow becomes flood biased in the MCR (Figure 38) for 
both the 150-ft- and the 200-ft-wide channels. Flood bias would bring sediment into the channel and be a cause of shoaling, an undesirable outcome.

The ebb bias current with opening of the SW Corner Cut and the flood bias flow with opening Parkers Cut are stronger with the wave current interaction. Appendix B presents calculated current velocities at sta 1, sta 2 , and sta 3 for Alts 0-6 without the wave-current interaction from the regional circulation model. These results agree with the findings from a previous numerical model study (Lin et al. 2001). Figures 39 to 44 show calculated maximum flood and ebb current flows, from the winter month simulation, for the new east jetty, opening SW Corner Cut, and opening Parkers Cut, respectively, with the 150-ft-wide channel. The strong ebb current, as shown in Figure 42, offers a benefit for maintaining the entrance channel for reducing sand settling and shoaling rate in the MCR.

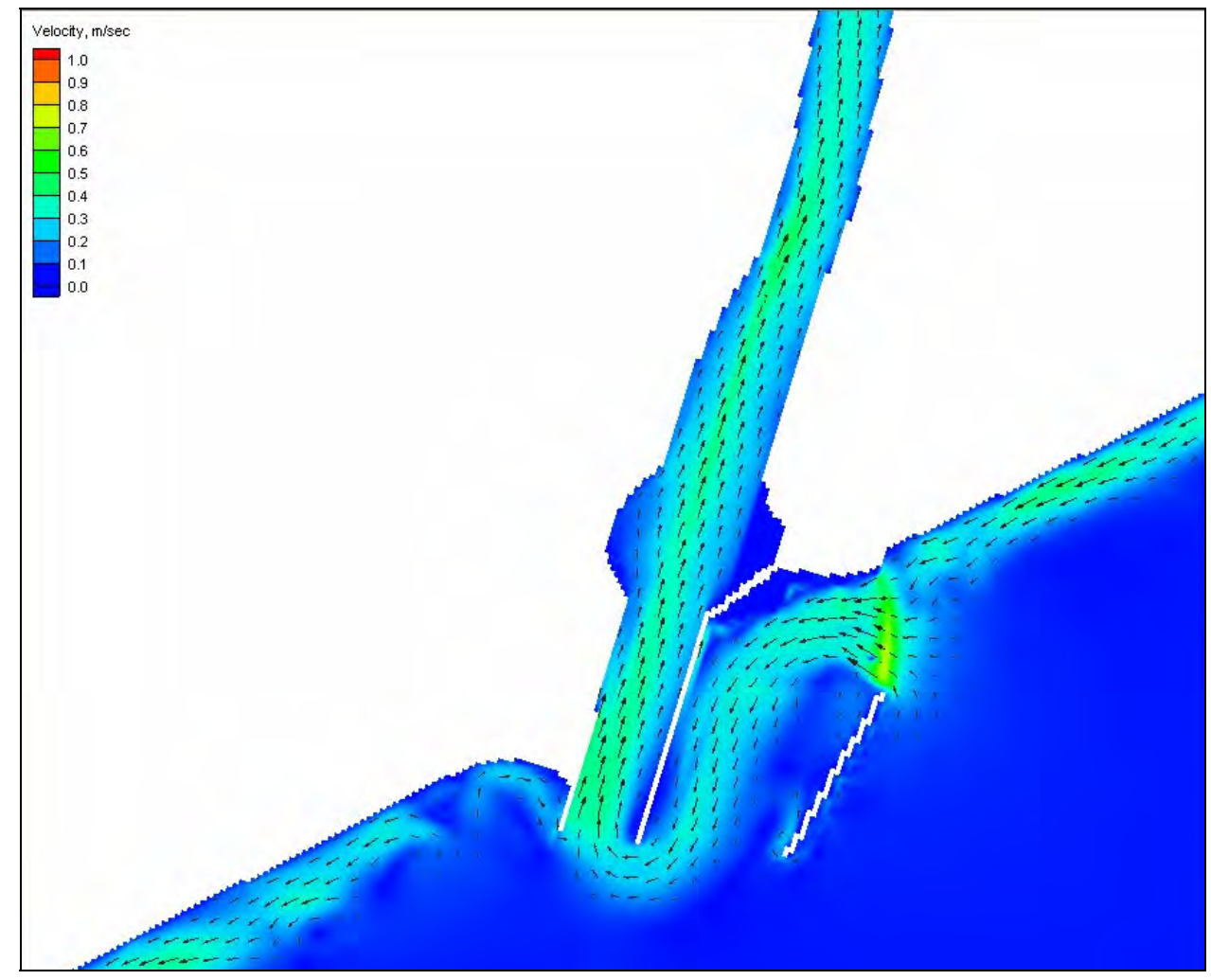

Figure 39. Calculated maximum flood current for new east jetty (Alt 1). 


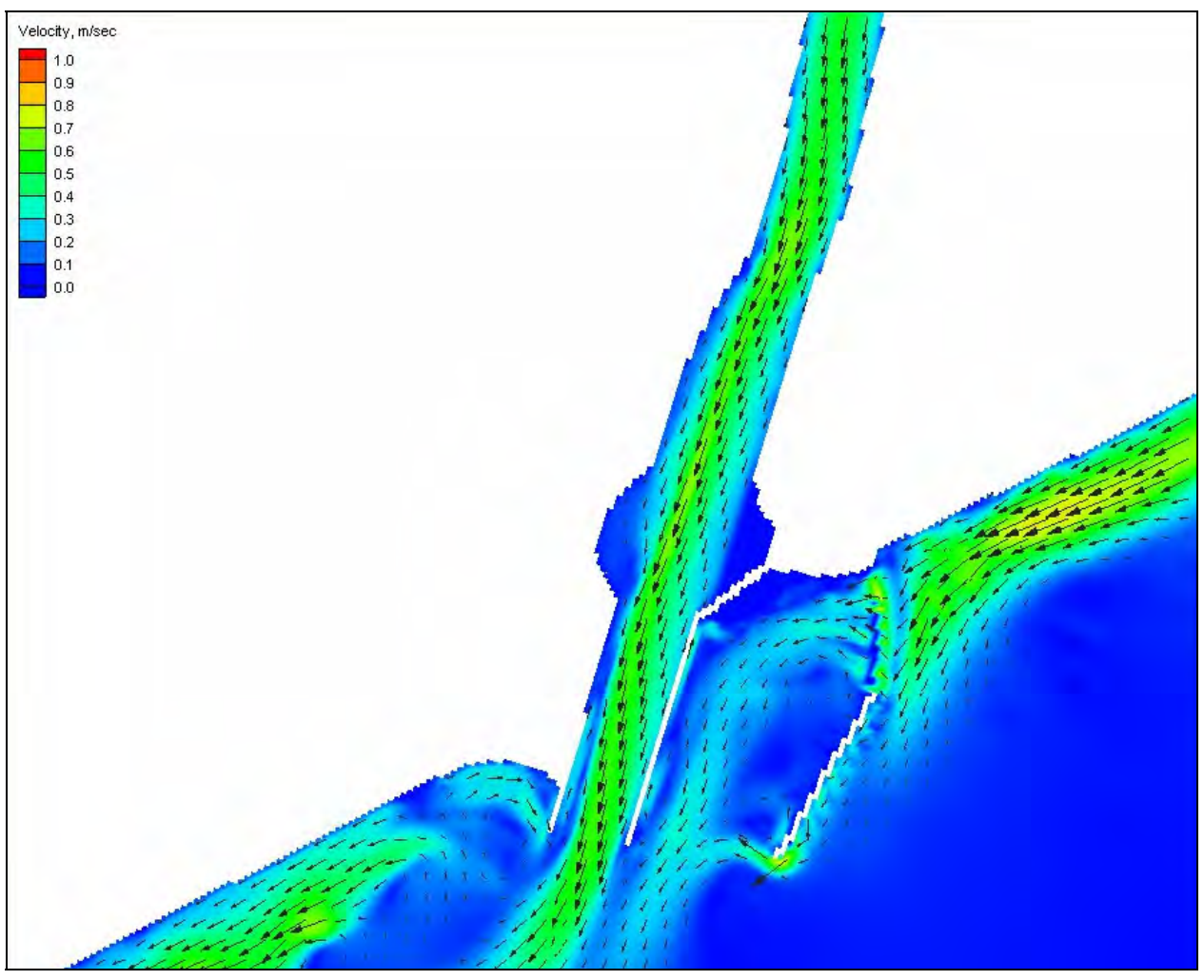

Figure 40. Calculated maximum ebb current for new east jetty (Alt 1).

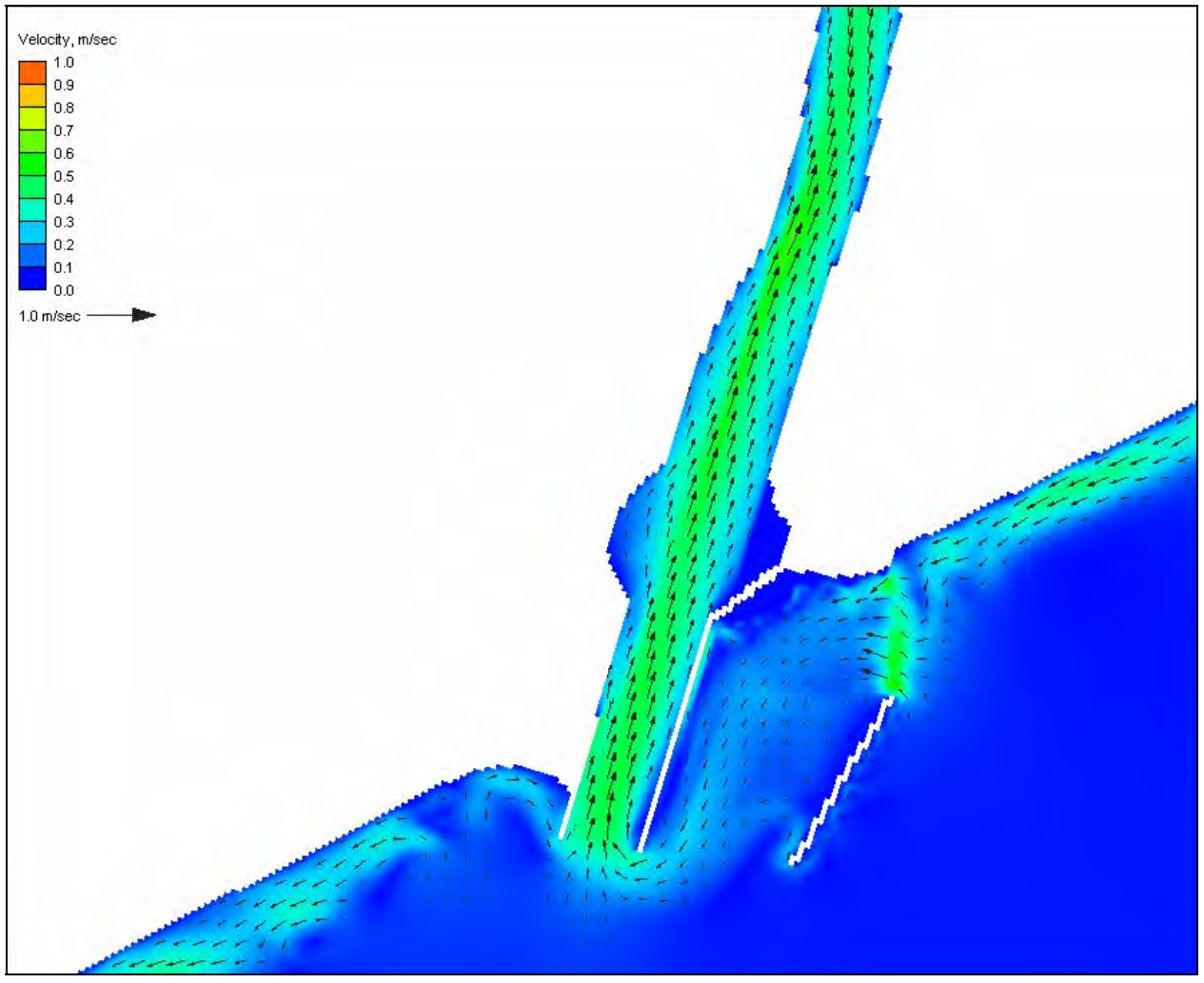

Figure 41. Calculated maximum flood current for opening SW Corner Cut (Alt 3). 


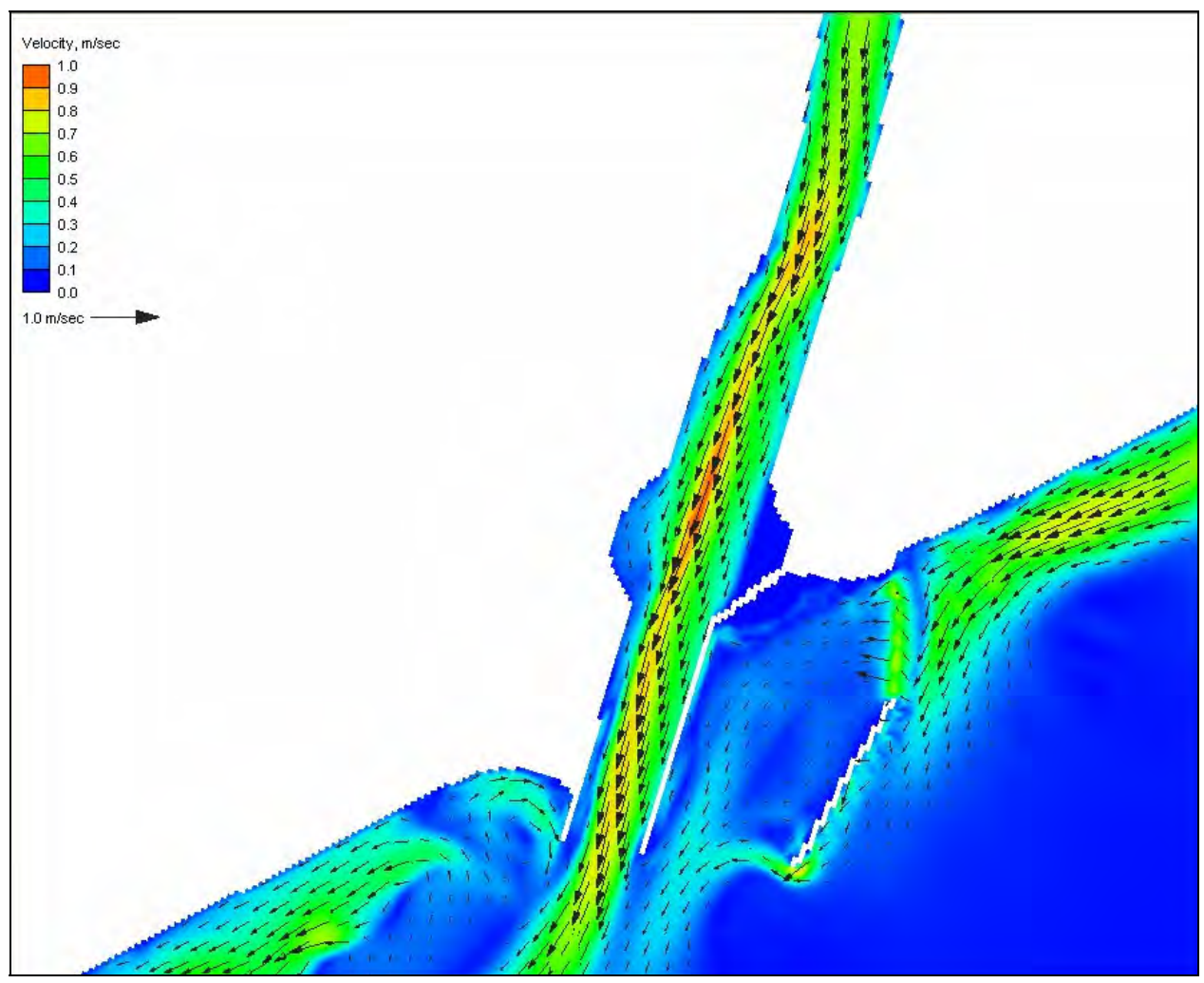

Figure 42. Calculated maximum ebb current for opening SW Corner Cut (Alt 3).

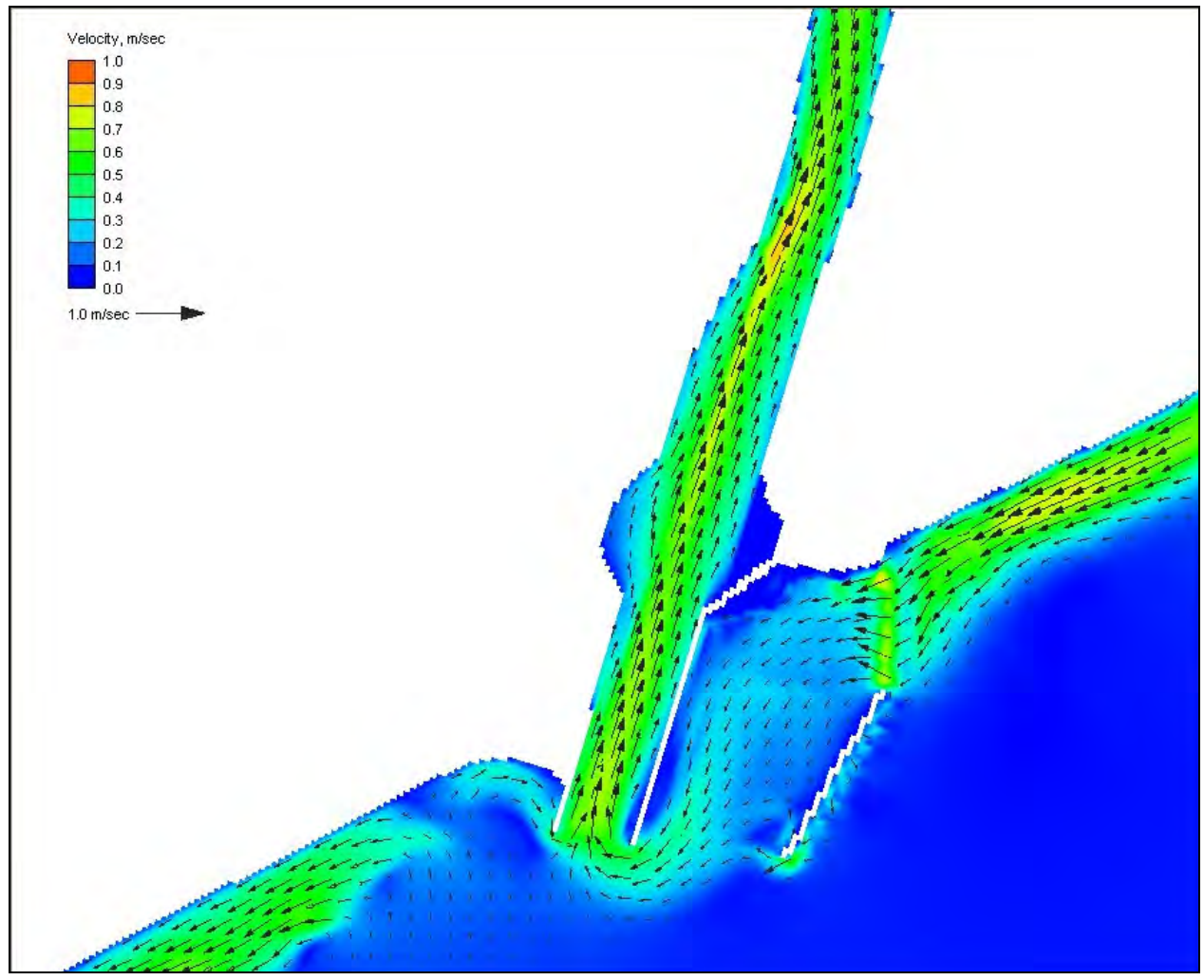

Figure 43. Calculated maximum flood current for opening Parkers Cut (Alt 5). 


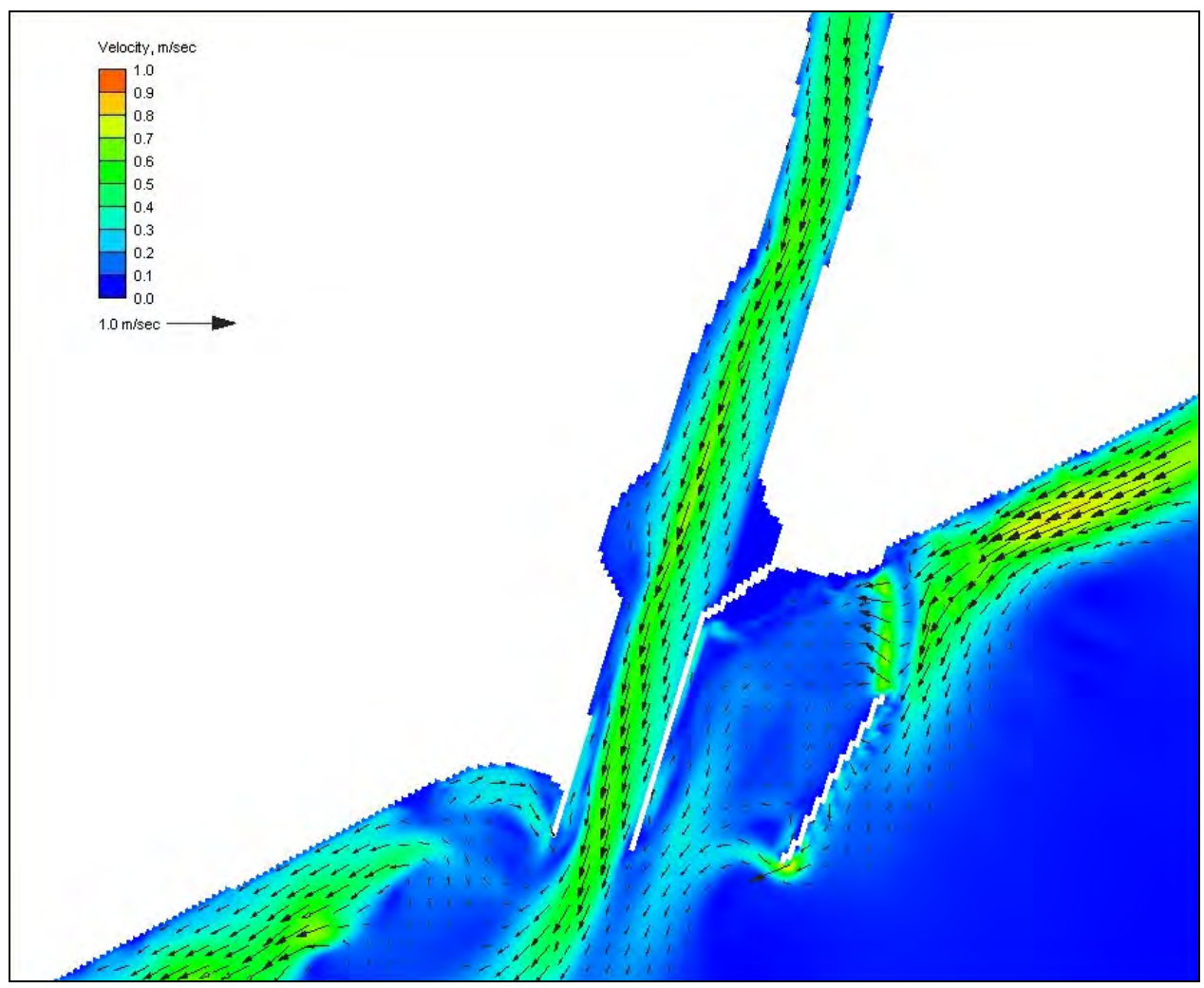

Figure 44. Calculated maximum ebb current for opening Parkers Cut (Alt 5).

\section{Morphology change}

Morphology change calculated from one winter month (January 2004) and one summer month (August 2004) was compared for the existing channel configuration (Alt 0) and new east jetty with and without opening SW Corner Cut and Parkers Cut (Alts 1 to 6). The sediment transport calculation of morphology change was based on the advection-diffusion equations that describe the role of suspended sediment transport as well as bed-load transport (Buttolph et al. 2006) and that best represent channel infilling (Ono et al. 2007). A median grain size of $0.15 \mathrm{~mm}$ (fine sand) was specified for the sediment transport calculation. Figures 45 and 46 show the morphology change and average sediment transport rate for Alt 0 with 150-ft-wide channel from the one winter month and one summer month simulations, respectively. Positive change corresponds to sand deposition, and negative change indicates erosion. More morphology change was calculated to occur in the winter month than in the summer month, as a result of greater sediment transport rates from the more energetic winter waves. 


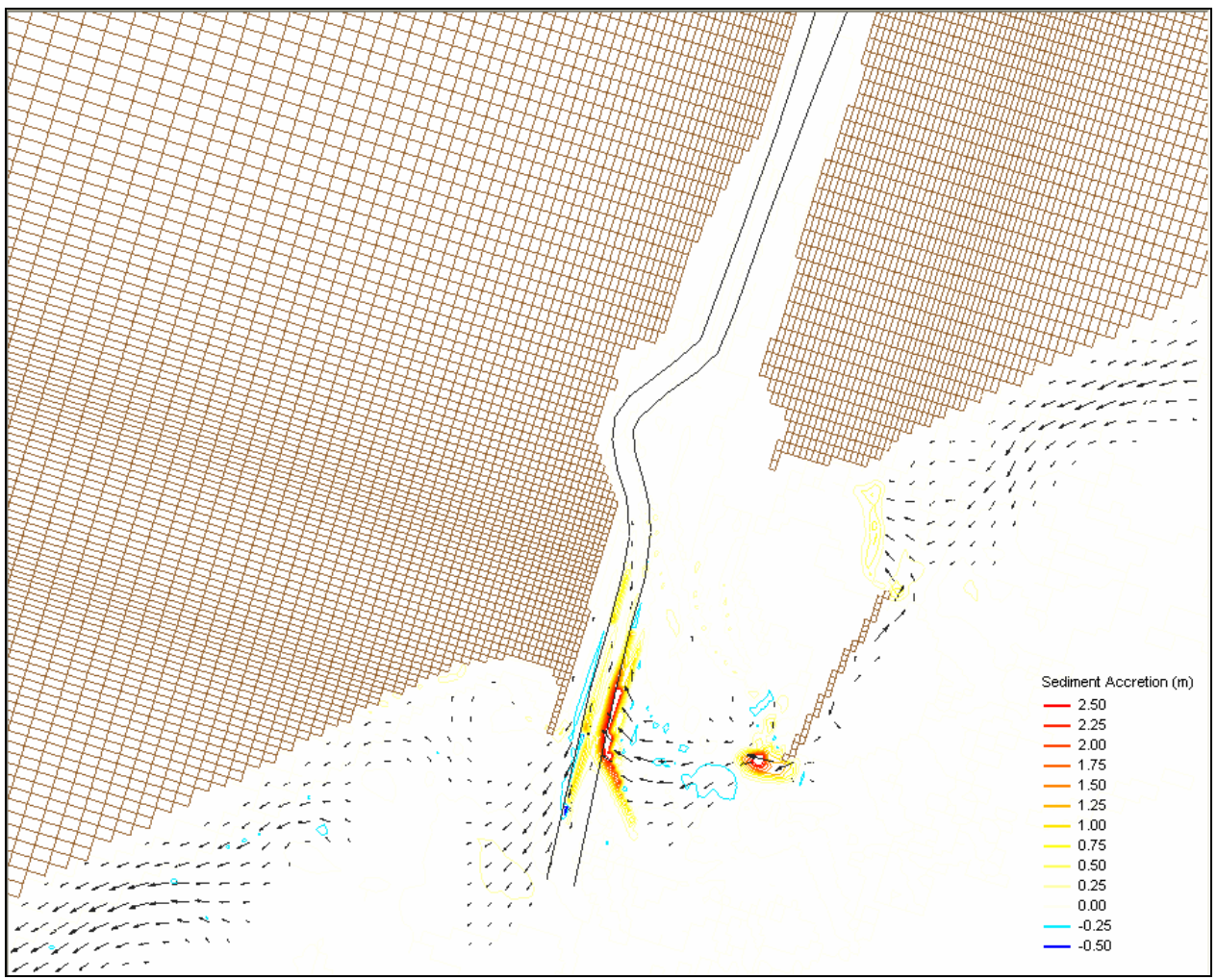

Figure 45. Winter-month morphology change and average transport rate for Alt 0.

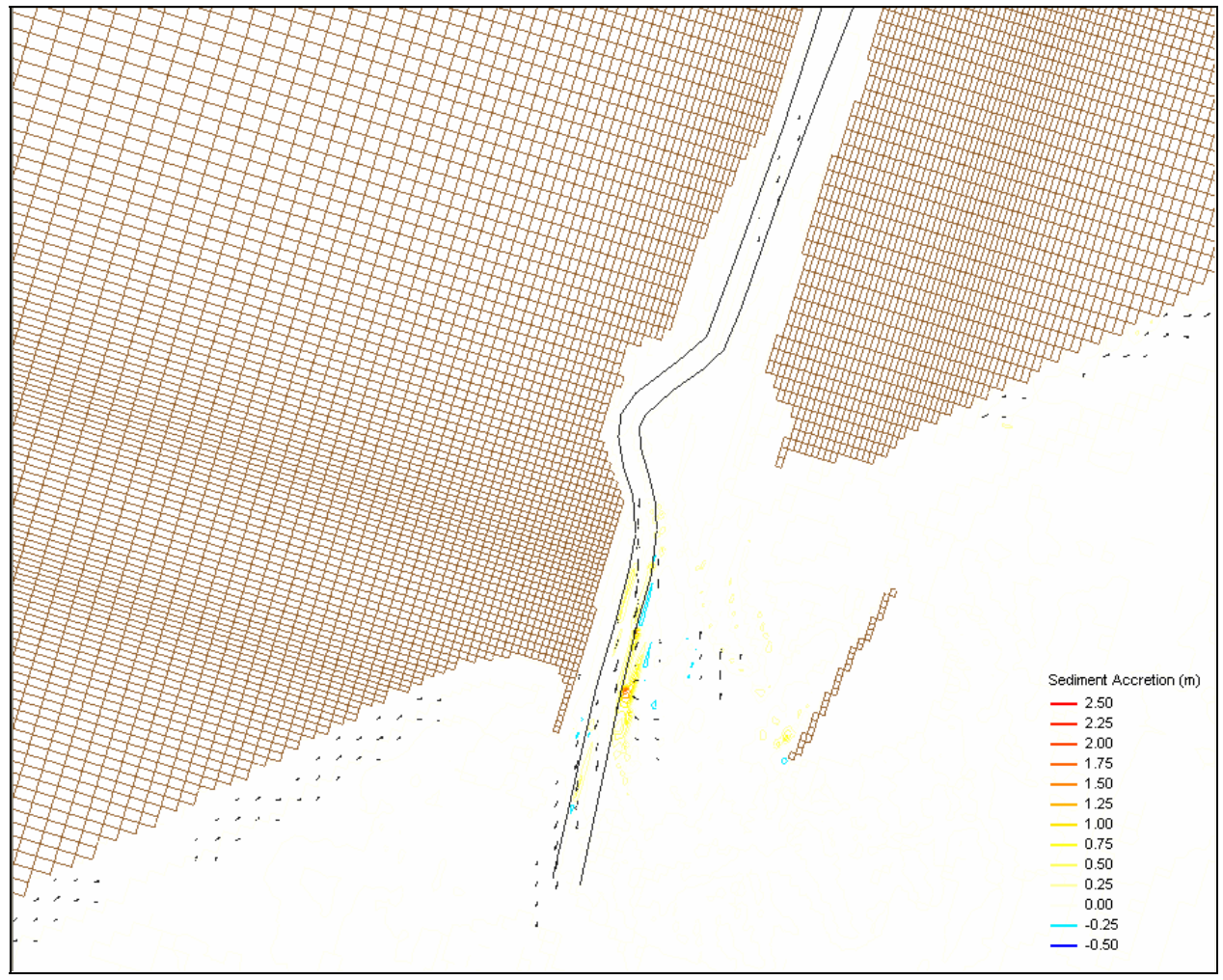

Figure 46. Summer-month morphology change and average transport rate for Alt 0. 
Figures 47 and 48 show the morphology change and average sediment transport rate from the one winter month and one summer month simulations, respectively, for the new east jetty with the 150 -ft-wide channel (Alt 1). Figures 49 and 50 show the morphology change and average sediment transport rate for one winter and one summer month, respectively, corresponding to the new east jetty with the 150-ft-wide channel and SW Cut open (Alt 3). Both calculated morphology change and average sediment transport rate are greater in the winter month than the summer month. Figure 51 shows the morphology change from the winter simulation for the new east jetty with 150 -ft-wide channel and Parkers Cut open (Alt 5). These simulations indicate that the morphology change in the entrance channel is smaller with the new jetty than without the newjetty. The calculated average transport rate field indicates that the sediment transport alongshore tends to bypass the mouth with the new jetty rather than being trapped at the entrance channel.

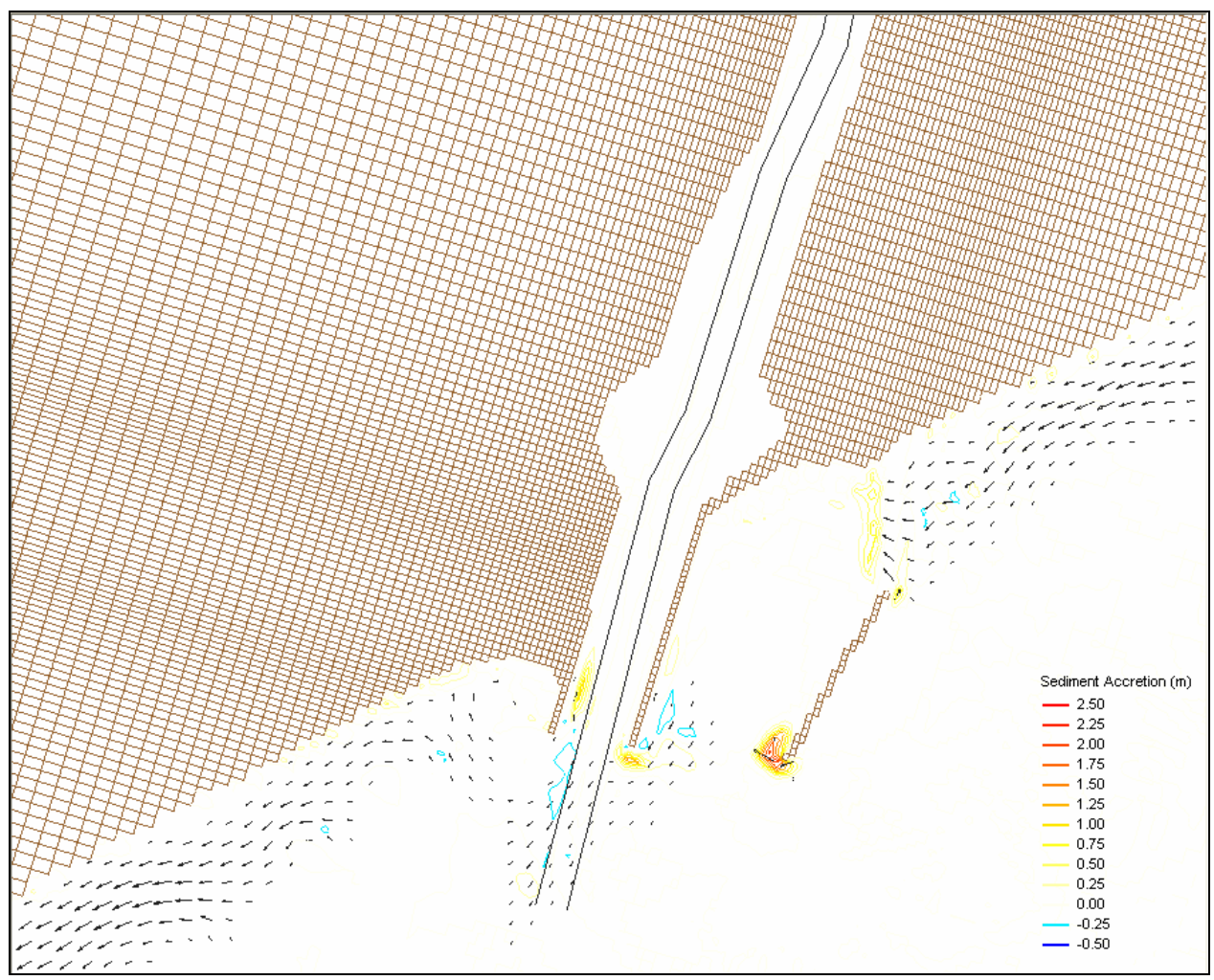

Figure 47. Winter-month morphology change and average transport rate for Alt 1. 


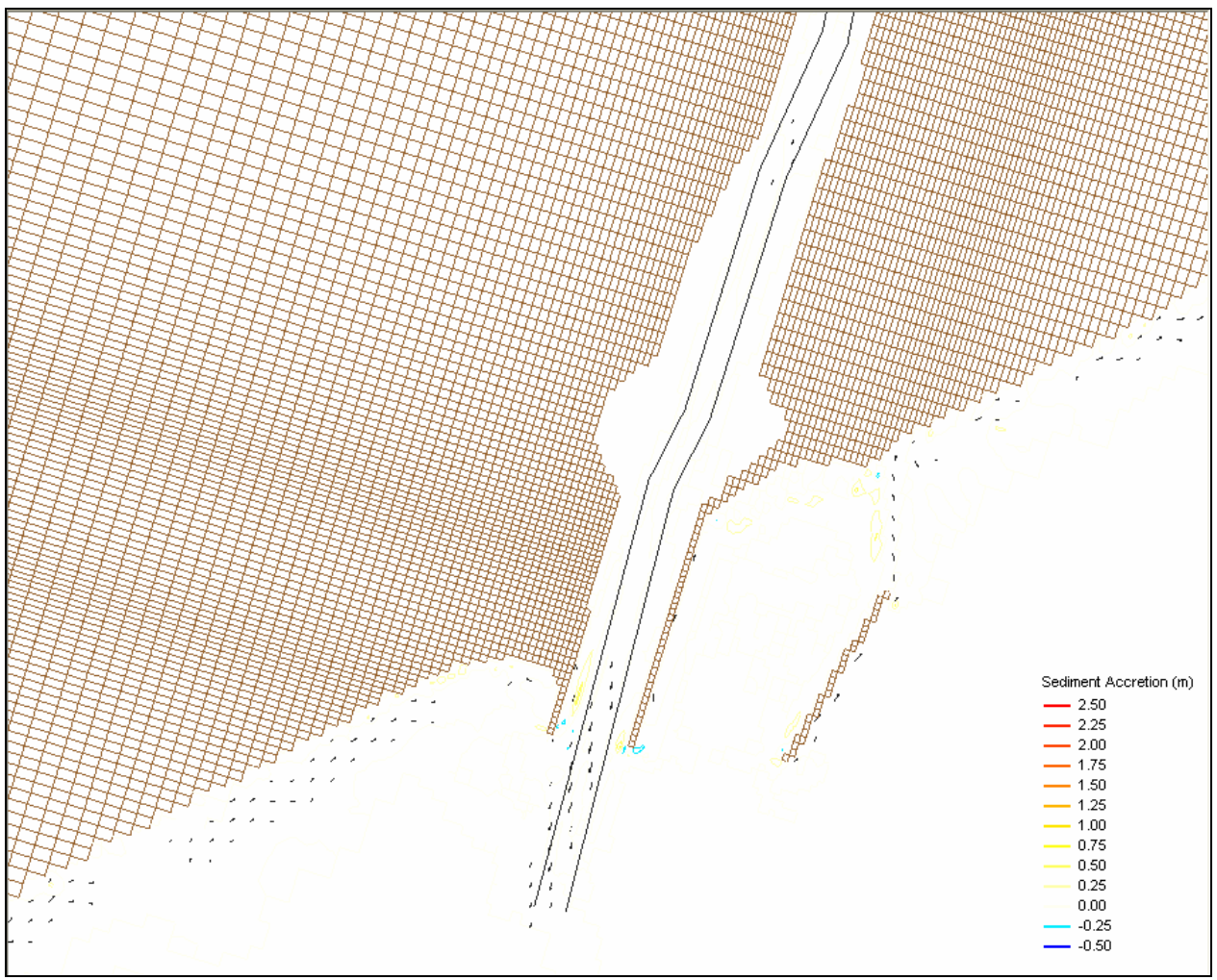

Figure 48. Summer-month morphology change and average transport rate for Alt 1.

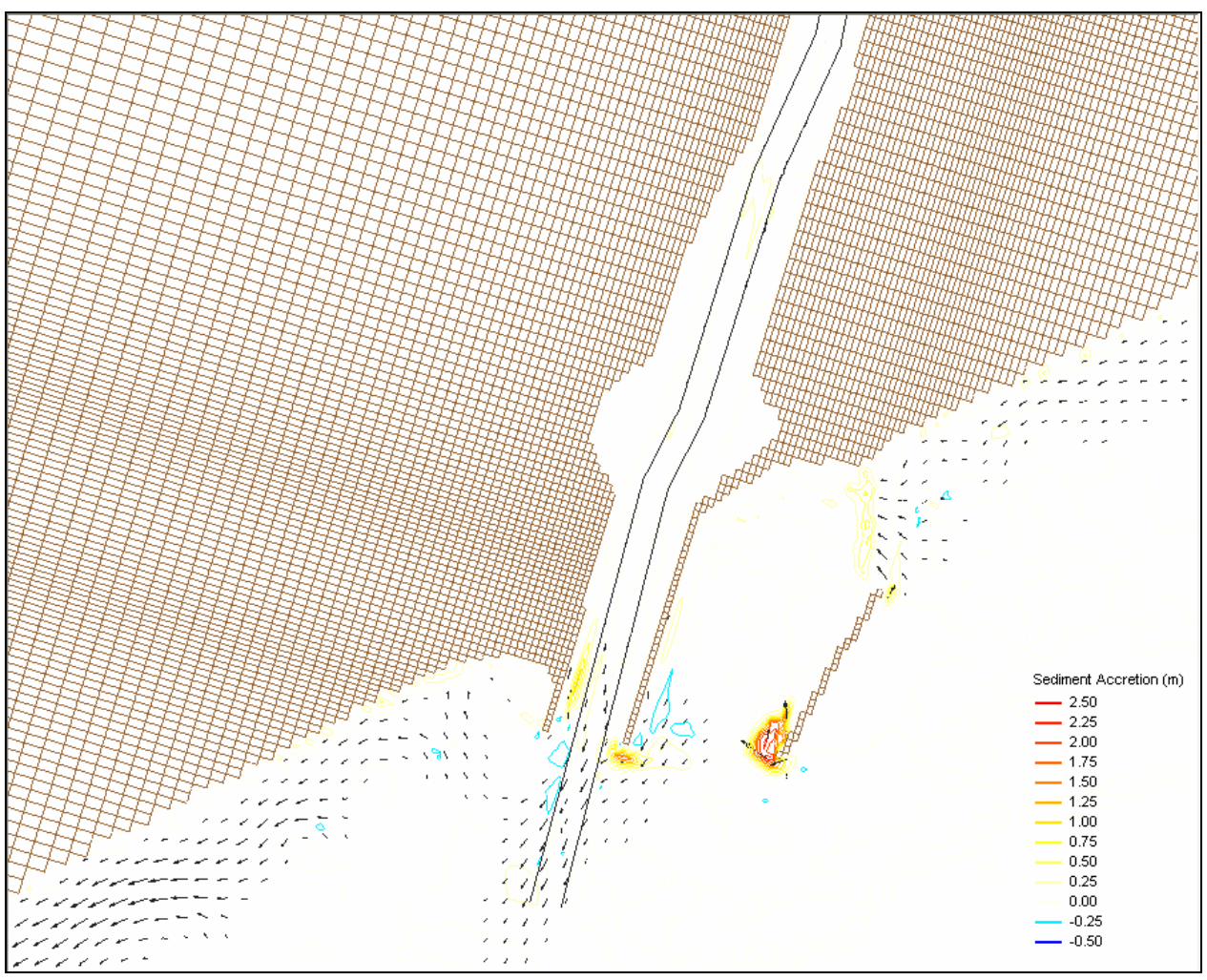

Figure 49. Winter-month morphology change and average transport rate for Alt 3. 


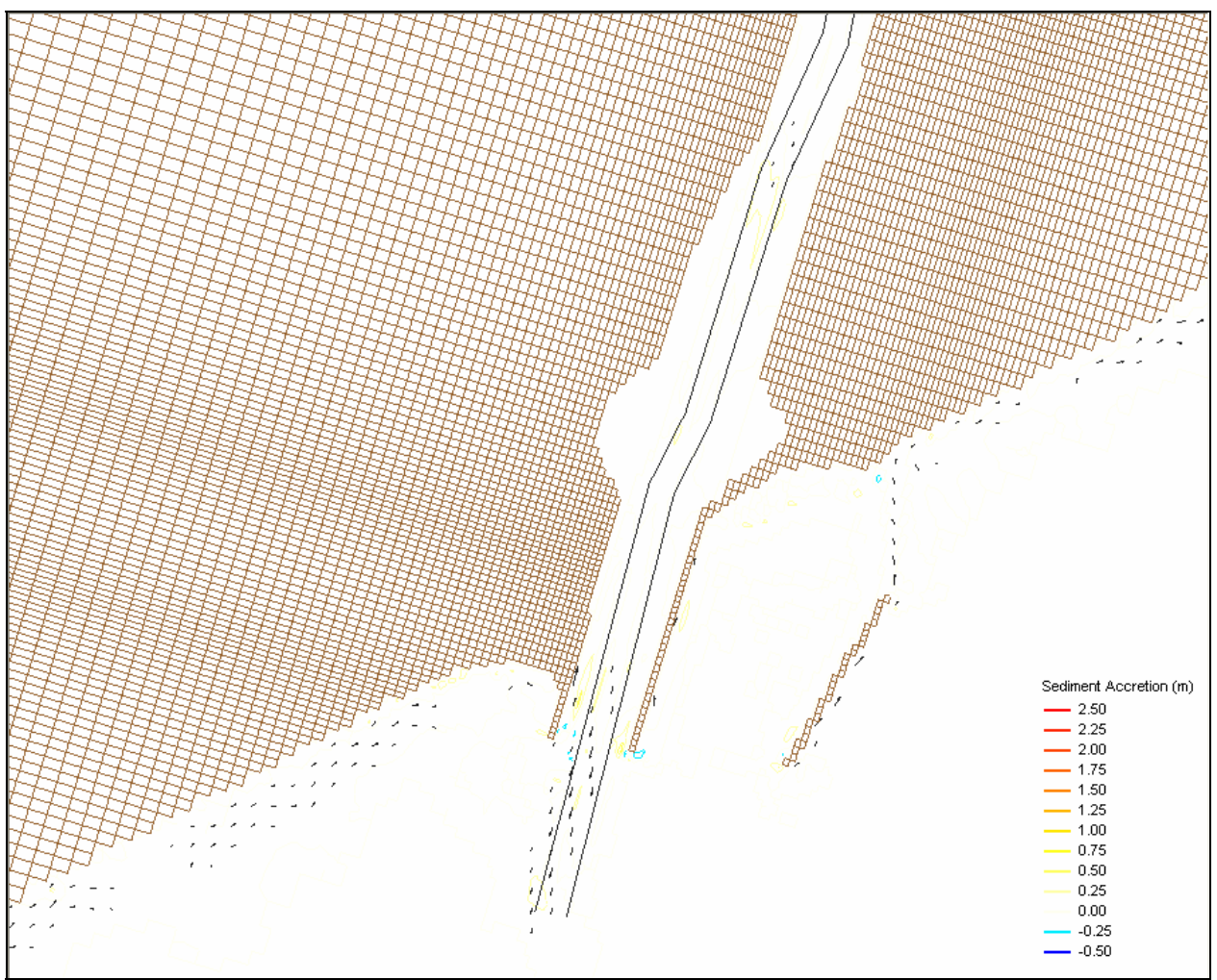

Figure 50. Summer-month morphology change and average transport rate for Alt 3.

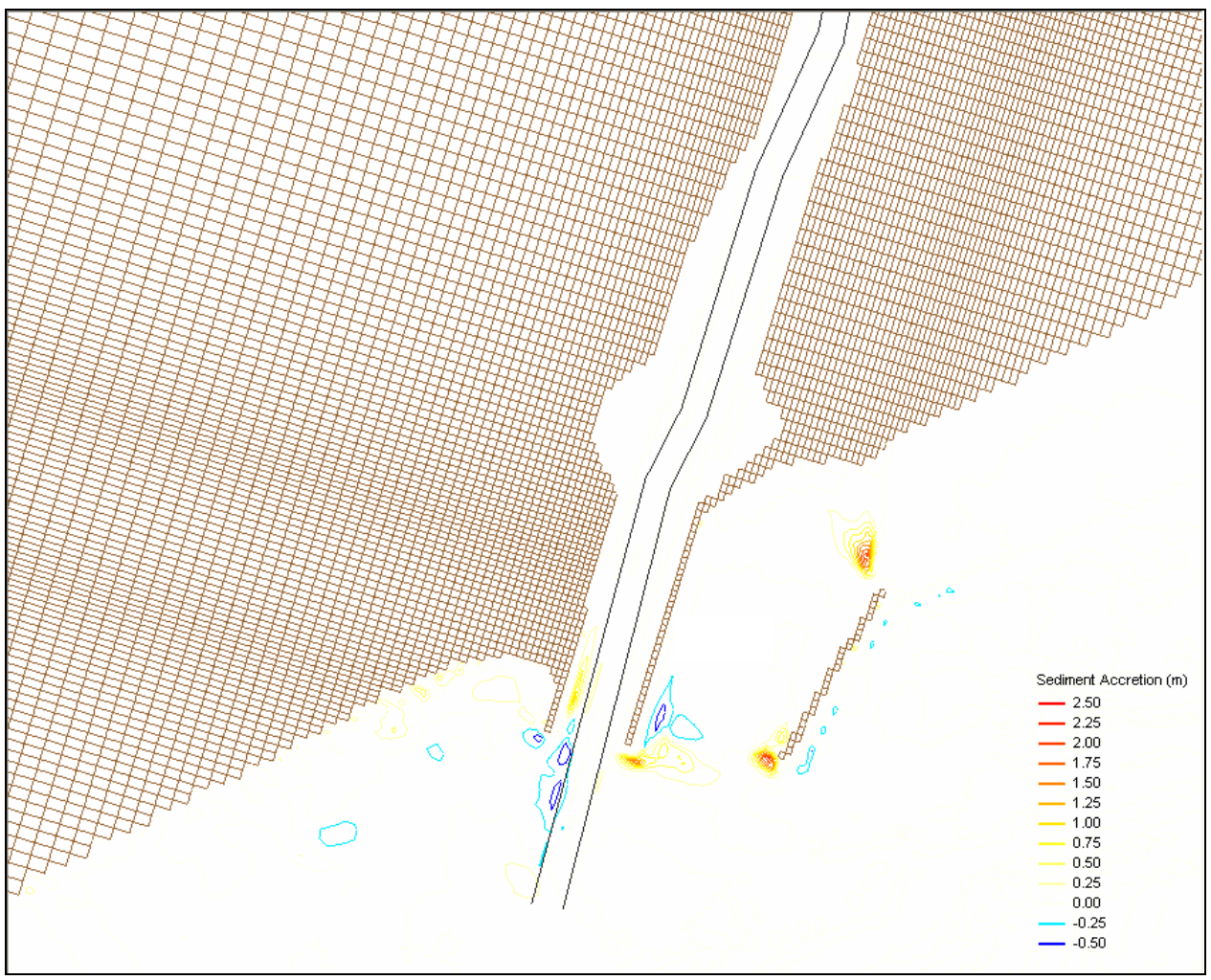

Figure 51. Winter-month morphology change for Alt 5. 
Figure 52 shows the calculated morphology change difference of the new jetty and 150-ft-wide channel with and without opening SW Corner Cut (Alts 1 and 3) for the winter month simulation. The sediment erosion patterns along the entrance channel are slightly different as a result of opening the SW Corner Cut in addition to the new jetty. The maximum difference of the along-channel erosion, in terms of depth change, is $15 \mathrm{~cm}$ for the 1-month simulation. There is also some sediment accumulation along the inner side of west jetty caused by the reversal of sediment transport direction between the jetty and entrance channel (Figures 47 to 50). For the winter-month simulation, Figure 53 shows the morphology change difference from the new jetty and 150-ft-wide channel with opening Parkers Cut (Alts 1 and 5). More sediment accretion occurs inside and at the mouth, with opening of Parkers Cut, as a result of stronger flood current at the mouth moving sand from the Gulf of Mexico into the channel.

Figures 54 to 56 show the calculated morphology change differences during a winter month between the 150-ft- and 200-ft-wide channel simulations for the new east jetty, opening the SW Corner Cut, and opening Parkers Cut, respectively. Only the 150-ft channel is outlined in these figures. For the new east jetty alone and for opening Parkers Cut, the difference in morphology change between 150- and 200-ft channels is small. For opening the SW Corner Cut, there is relatively more sand deposition (maximum positive change is $30 \mathrm{~cm}$ or $1 \mathrm{ft}$ ) at the mouth for the $200-\mathrm{ft}$ channel and more scour ( $40 \mathrm{~cm}$ or $1.3 \mathrm{ft}$ ) along the 150 - $\mathrm{ft}$ channel from the winter-month simulations, as a result of stronger ebb current in the $150-\mathrm{ft}$ channel than in the 200-ft channel.

Additional simulations were conducted for one summer and one winter month for moving the new east jetty westward by $100 \mathrm{ft}$ (Alt 7), as a sensitivity test of a narrower mouth width. These simulations give a 400 -ft distance between the jetties. The morphology change calculated for this alternative with the 150-ft-wide channel is found similar to that for the wider mouth (Alt 1). Figure 57 shows the winter month morphology change and average sediment transport rate field for Alt 7 . Therefore, the difference of morphology change between Alts 1 and 7 was found to be insignificant based on these simulations. 


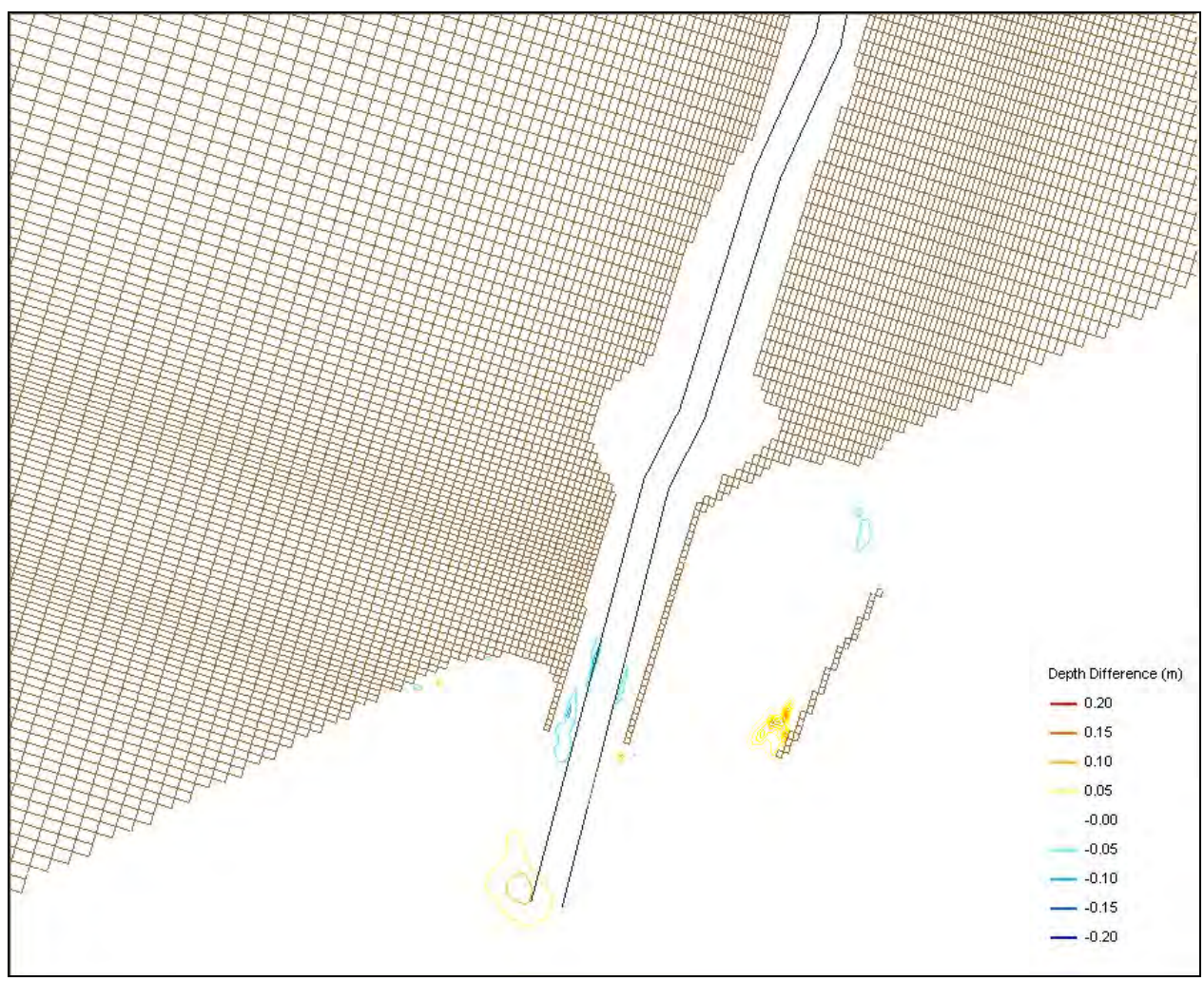

Figure 52. Winter-month morphology difference between Alts 1 and 3.

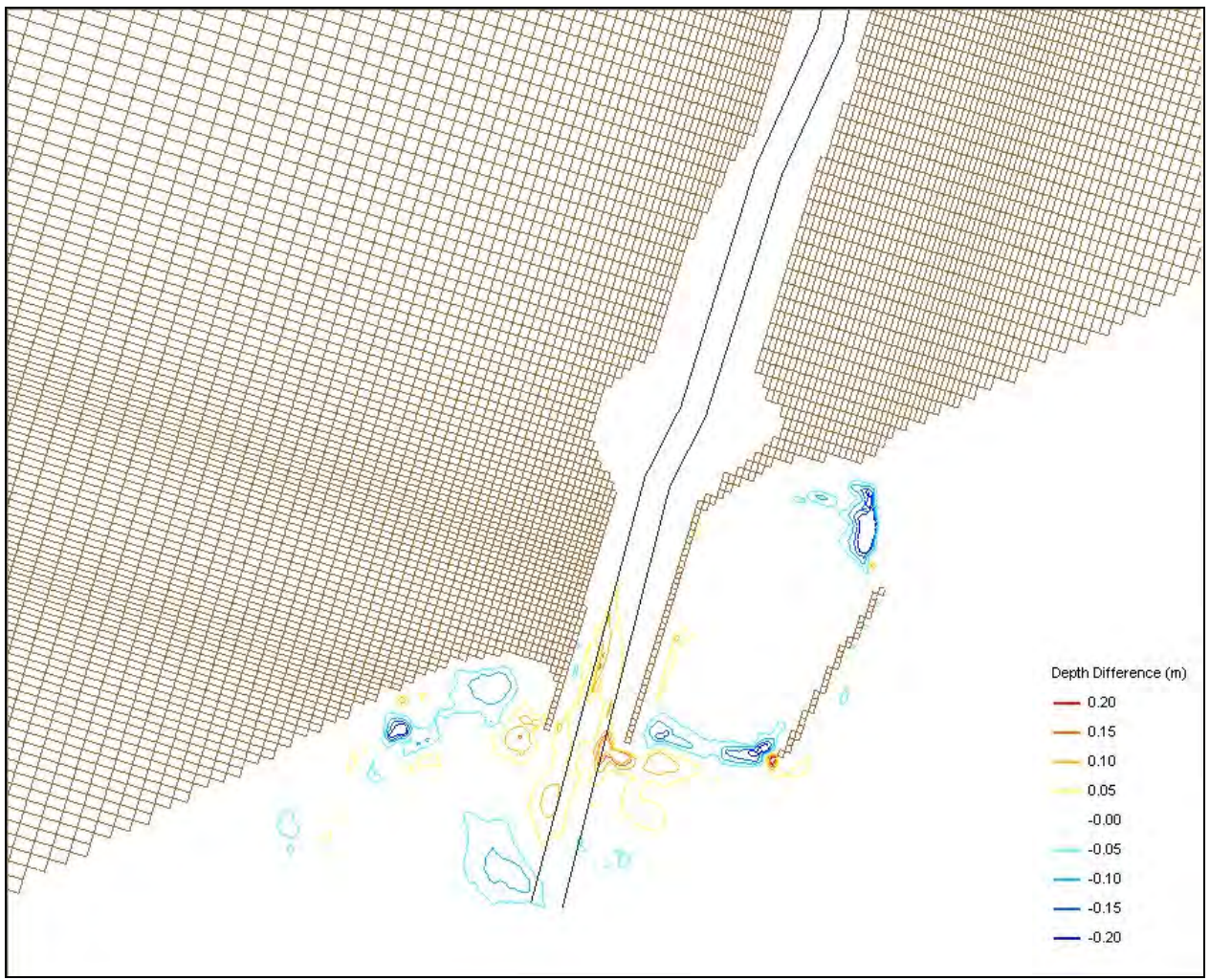

Figure 53. Winter-month morphology difference between Alts 1 and 5. 


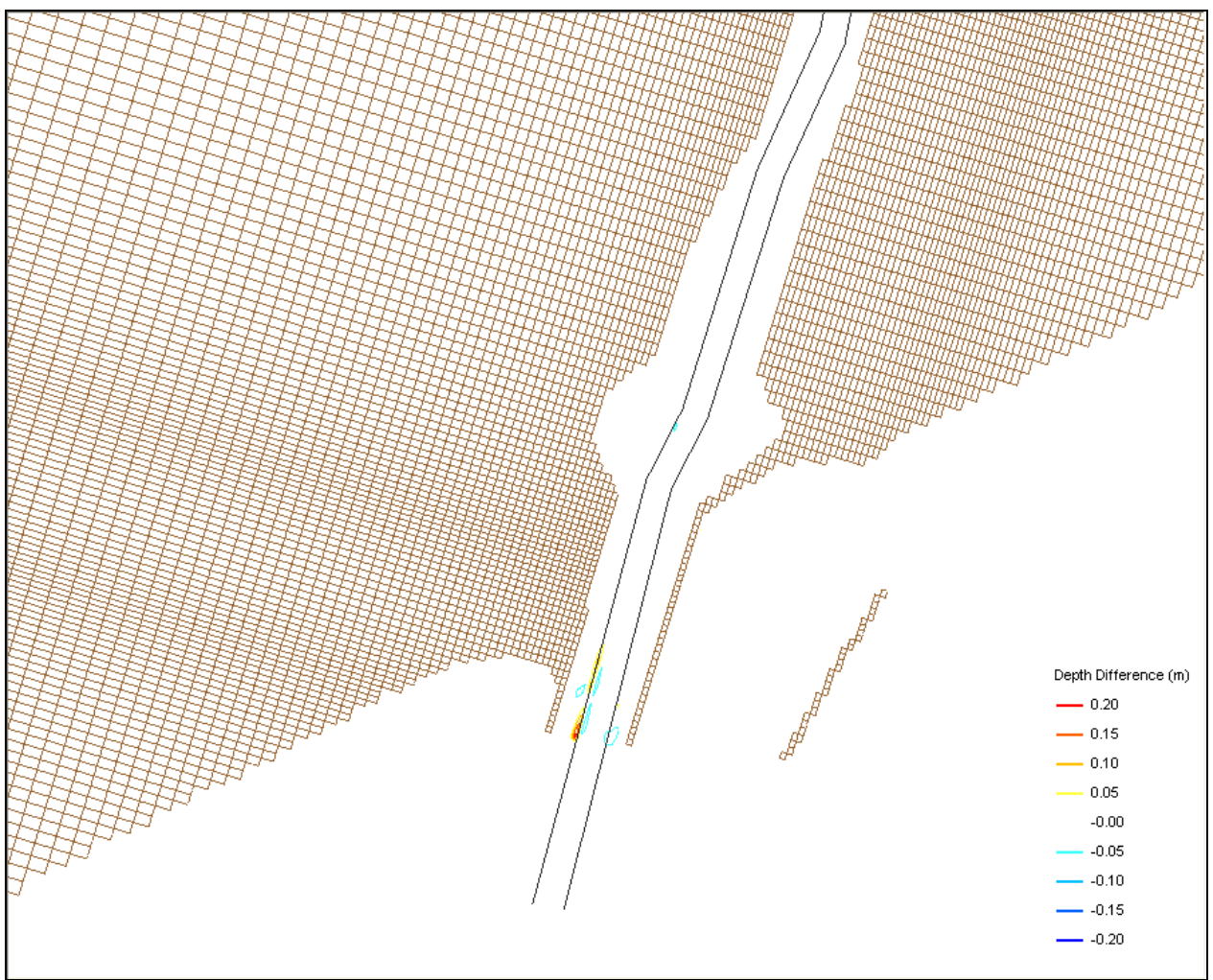

Figure 54. Winter-month morphology difference between Alts 1 and 2.

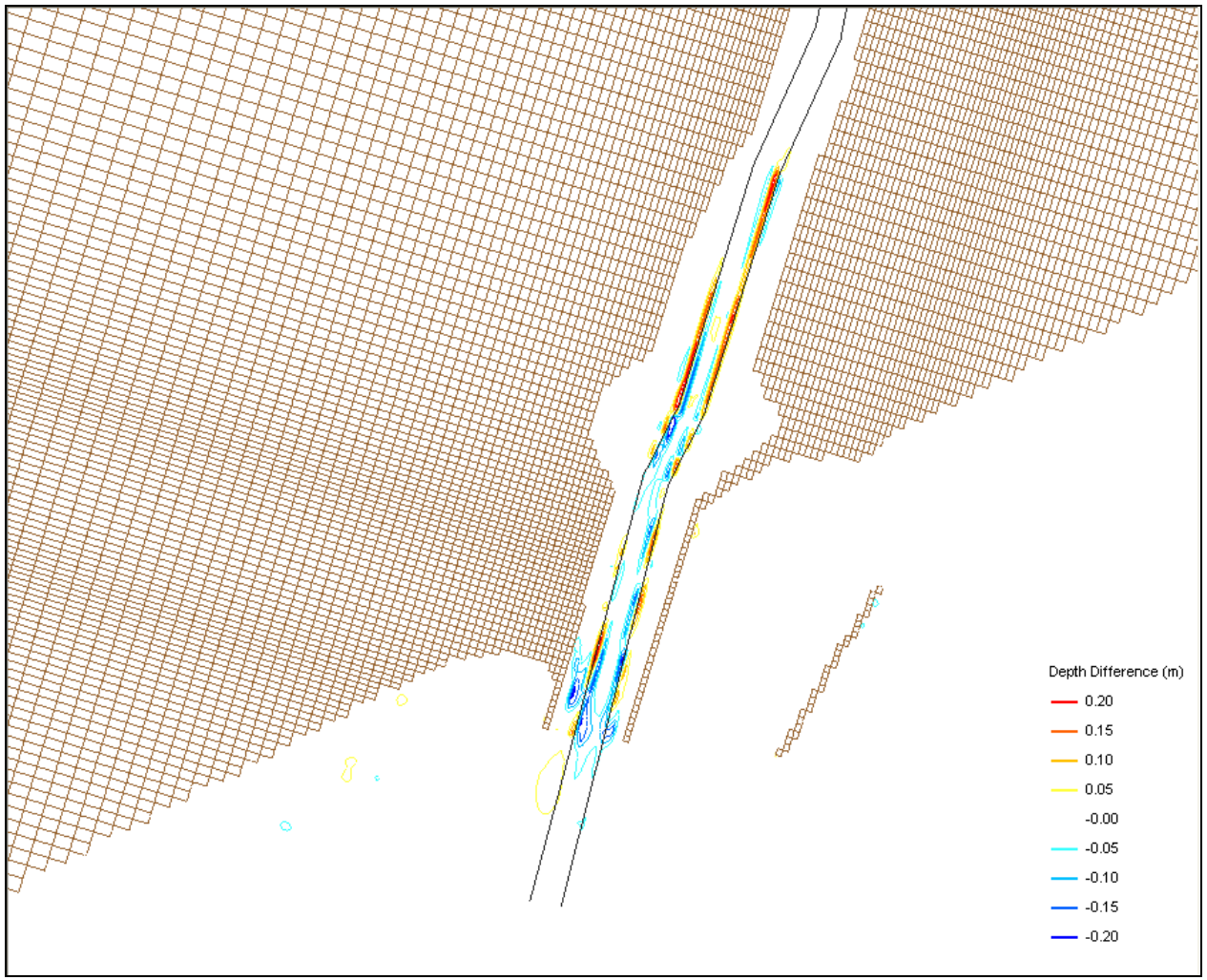

Figure 55. Winter-month morphology difference between Alts 3 and 4. 


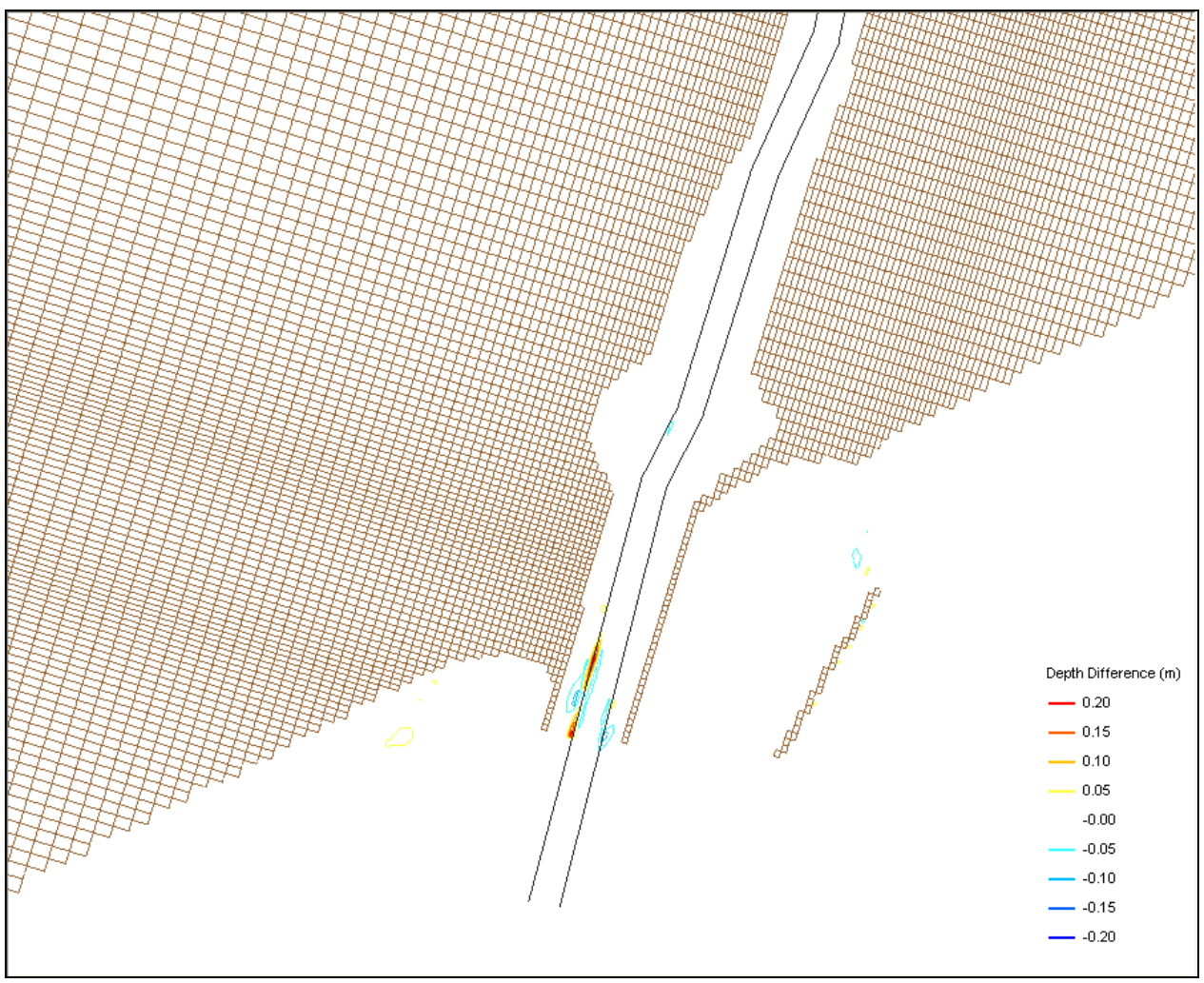

Figure 56. Winter-month morphology difference between Alts 5 and 6.

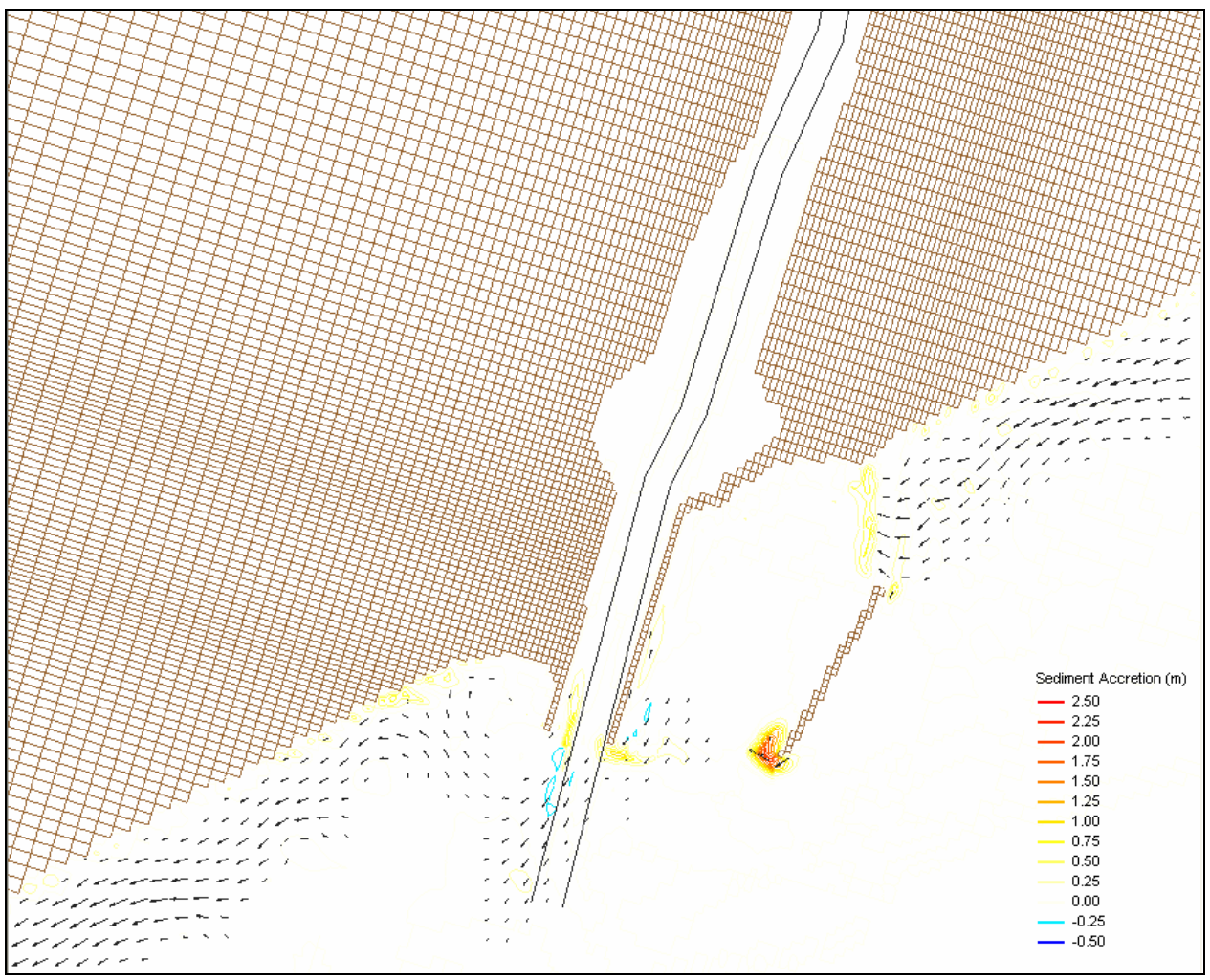

Figure 57. Winter-month morphology change for Alt 7. 
Table 10 presents the calculated sediment volume change inside and outside the channel entrance areas, and in the sediment impoundment basin (Figure 58) from the summer-month and winter-month simulations for Alts $0,1,3,5$, and 7. For dredging the existing channel alone without the new jetty (Alt 0), the estimated annual sediment accretion in the entrance and basin is more than twice as great as for other alternatives with the new jetty. These simulations show that the sediment can enter the entrance channel more easily and quickly without the new jetty. Among the alternatives with the new jetty, opening Parkers Cut produces more sediment accretion inside the entrance area, whereas opening the SW Corner Cut produces more sediment accumulation outside the entrance area. There is slightly more sediment accumulation in the deposition basin area with the new jetty alone (Alt 1) than for the other alternatives.

Table 10. Estimated sediment volume change (cu yd).

\begin{tabular}{|l|c|l|c|l|l|l|l|}
\hline & \multicolumn{2}{|c|}{$\begin{array}{c}\text { Inside Entrance } \\
\text { (Area A) }\end{array}$} & \multicolumn{2}{c|}{$\begin{array}{c}\text { Outside Entrance } \\
\text { (Area B) }\end{array}$} & $\begin{array}{l}\text { Sediment Deposition } \\
\text { Basin (Area C) }\end{array}$ & $\begin{array}{l}\text { Summation } \\
\text { (A, B, and C) }\end{array}$ \\
\cline { 2 - 8 } Alt & $\begin{array}{l}\text { Winter } \\
\text { Month }\end{array}$ & $\begin{array}{l}\text { Summer } \\
\text { Month }\end{array}$ & $\begin{array}{l}\text { Winter } \\
\text { Month }\end{array}$ & $\begin{array}{l}\text { Summer } \\
\text { Month }\end{array}$ & $\begin{array}{l}\text { Winter } \\
\text { Month }\end{array}$ & $\begin{array}{l}\text { Summer } \\
\text { Month }\end{array}$ & Annual 1 \\
\hline 0 & 24,100 & 7,200 & 7,500 & 1,700 & 12,700 & $-1,100$ & 384,000 \\
\hline 1 & 2,100 & -600 & $-1,200$ & 1,100 & 14,700 & 5,000 & 145,000 \\
\hline 3 & 2,700 & 500 & 600 & 2,200 & 15,600 & 3,300 & 175,000 \\
\hline 5 & 3,400 & 500 & -200 & 1,700 & 16,000 & 3,000 & 174,000 \\
\hline 7 & 2,000 & -700 & 70 & 1,400 & 16,000 & 3,000 & 146,000 \\
\hline 1 Estimation based on 8*(one winter-month change)+4*(one summer-month change). \\
\hline \multicolumn{8}{|c|}{}
\end{tabular}

\section{Summary and discussion}

Tidal inlet processes at the MCR are the result of combined astronomical tidal current, wind-generated current, wave-induced current and wave action, and river discharge. These processes were investigated by a regional circulation model, the CMS project-level model, and calculations of the nearshore wave transformation, tidal hydrodynamics, and sediment transport. The regional model simulated the circulation and water level for both East Matagorda Bay and Matagorda Bay with multiple inlets including the MCR. The results from the regional model were input to the CMS for estimation of the local flow pattern, sediment transport rates, and morphology change at the MCR for simulations over one representative winter month and one representative summer month. 


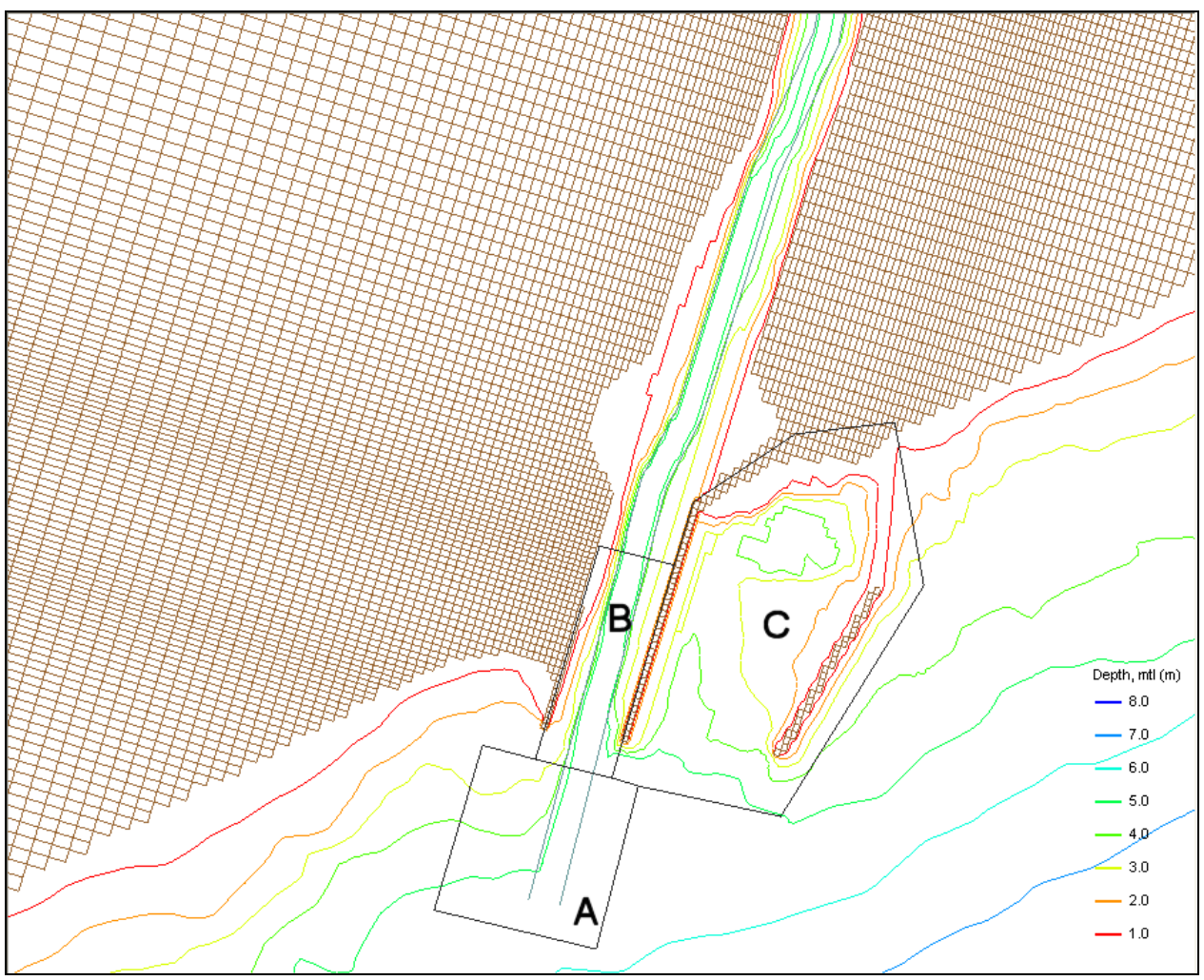

Figure 58. Areas A, B, and C for sediment volume change calculations.

Figures 36 to 38 show the calculated current at sta 1, sta 2, and sta 3 of the new east jetty with and without opening the SW Corner Cut and Parkers Cut. The current for new east jetty alone (Alt 1) is slightly ebb biased. The current magnitude is more similar between sta 1 and sta 3 with the new east jetty condition than with opening the SW Corner Cut and Parkers Cut. Opening the SW Corner Cut creates a more ebb biased condition (Kraus and Militello 1996, 1999). In contrast, opening Parkers Cut will turn the current to flood biased in the CRNC (Lin et al. 2001).

A stronger current and greater ebb bias are predicted for the opened SW Corner Cut. Opening the SW Corner Cut increases the ebb current primarily because of higher water level induced by set-up by wind at the southwestern end of the East Matagorda Bay. Water enters East Matagorda Bay from the GIWW and from Mitchells Cut, located on the northeast corner of the bay, and exits at the SW Corner Cut. Overall, the peak ebb current magnitude increases approximately 50 percent with the SW Corner Cut open (Figures 36 and 37). An increase in ebb current in the $\mathrm{CRNC}$ is favorable for maintaining the MCR. 
Calculated morphology change and average sediment transport rate are shown to be greater in the representative winter month than the summer month. Calculated sand accumulation at the mouth is less with the new jetty than for the existing condition. The calculated average transport rate indicates that the longshore sediment tends to bypass the mouth with the new jetty rather than being trapped at the entrance channel.

Calculations show overall small differences in water level, current magnitude, and morphology change predictions for a 150-ft-wide channel or a 200 -ft-wide channel. The current magnitude is slightly stronger in the narrower channel, because of smaller cross section. For opening the SW Corner Cut, there is relatively more sand deposition at the mouth for the 200 - $\mathrm{ft}$ channel and more scour along the $150-\mathrm{ft}$ channel from the wintermonth simulations. 


\section{Preliminary Jetty Design}

The preliminary design of a new east jetty for the MCR is presented in this chapter. The overall design goals are to increase the dredging interval for the navigation channel and thereby improve navigation reliability. The cross-sectional dimensions, armor stone stability, and geotechnical parameters of the proposed jetty are assessed to accomplish these goals.

Existing jetties at the project site and along the Texas coast were reviewed as a first step for this preliminary design. The proposed cross section is based partially on the original design of the east jetty at the MCR (USACE 1977). Consideration was also given to constructibility issues illuminated by construction of similar jetties protecting a shallow-draft channel recently completed by the Galveston District at Packery Channel inlet, TX.

\section{Review of existing jetties on Texas coast}

J etty cross section and armor stone weight at the nine Federally maintained inlets on the Texas Gulf Coast were compared, based in part on data compiled by Sargent and Bottin (1989) (Table 11). These jetties were constructed with rectangular-shaped armor stone. Emphasis in analysis was given to the existing jetties at the MCR and the newest jetties on the Texas Gulf Coast at Packery Channel, Corpus Christi, TX (Williams et al. 2007) (Chapter 1). The MCR is presently stabilized by a traditional impermeable jetty to the west of the navigation channel and a weir jetty to the east. Both jetties at the MCR have typical top widths ( $16 \mathrm{ft}$ ) and higher than average crest elevations for Texas coast jetties (+6.4 ft NAVD881). Surveys performed in J anuary 2007 as part of this study indicate that the crest elevations along both MCR jetties are greater than the originally specified elevation at most locations (Figure 59), suggesting that settlement associated with local consolidation of foundation soils and/ or regional land subsidence has been minimal.

1 North American Vertical Datum, 1988. 
Table 11. Selected properties of existing jetties on Texas coast.

\begin{tabular}{|c|c|c|c|c|c|c|c|}
\hline \multirow[b]{3}{*}{ Location } & \multirow[b]{3}{*}{$\begin{array}{l}\text { Crest } \\
\text { Width, } \mathrm{ft}\end{array}$} & \multicolumn{4}{|c|}{ Crest Elevation, ft (NAVD88) } & \multirow[b]{3}{*}{$\begin{array}{l}\text { Side } \\
\text { Slope }\end{array}$} & \multirow{3}{*}{$\begin{array}{l}\text { Armor Stone } \\
\text { Weight, Head } \\
\text { Section, ton }\end{array}$} \\
\hline & & \multicolumn{2}{|c|}{ Landward Section } & \multicolumn{2}{|c|}{ Seaward Section } & & \\
\hline & & $\begin{array}{l}\text { North/East } \\
\text { Jetty }\end{array}$ & $\begin{array}{l}\text { South/West } \\
\text { Jetty }\end{array}$ & $\begin{array}{l}\text { North/East } \\
\text { Jetty }\end{array}$ & $\begin{array}{l}\text { South/West } \\
\text { Jetty }\end{array}$ & & \\
\hline Sabine Pass & 10 & +6.3 & +3.3 & +5.0 & +3.3 & $1.5: 1$ & $9-13$ \\
\hline $\begin{array}{l}\text { Galveston } \\
\text { Channel }\end{array}$ & 16 & +5.1 & +4.6 & \multicolumn{2}{|c|}{+3.6} & $3: 1$ & $16-18$ \\
\hline $\begin{array}{l}\text { Freeport } \\
\text { Channel }\end{array}$ & 16 & \multicolumn{2}{|c|}{+5.5} & \multicolumn{2}{|c|}{+6.5} & $3: 1$ & $16-18$ \\
\hline $\begin{array}{l}\text { Mouth of } \\
\text { Colorado River }\end{array}$ & 16 & \multicolumn{2}{|c|}{+6.4} & \multicolumn{2}{|c|}{+6.4} & $3: 1$ & $\begin{array}{l}\text { East Jetty: } \\
16-18 \\
\text { West Jetty: } \\
10-12\end{array}$ \\
\hline $\begin{array}{l}\text { Matagorda Ship } \\
\text { Channel }\end{array}$ & 16 & \multicolumn{2}{|c|}{+6.7} & \multicolumn{2}{|c|}{+6.7} & $2: 1$ & $14-18$ \\
\hline Aransas Pass & 16 & \multicolumn{2}{|c|}{+4.6} & \multicolumn{2}{|c|}{+4.6} & 3.5:1 & $16-18$ \\
\hline $\begin{array}{l}\text { Packery } \\
\text { Channel }\end{array}$ & 10.5 & \multicolumn{2}{|c|}{+5.3} & \multicolumn{2}{|c|}{+7.3} & $2: 1$ & 10 \\
\hline Mansfield Pass & 16 & \multicolumn{2}{|c|}{+6.7} & \multicolumn{2}{|c|}{+6.7} & $3: 1$ & $6-10$ \\
\hline $\begin{array}{l}\text { Brazos } \\
\text { Santiago Pass }\end{array}$ & 16 & \multicolumn{2}{|c|}{+4.8} & \multicolumn{2}{|c|}{+4.8} & $3: 1$ & $16-18$ \\
\hline
\end{tabular}

The jetties at Packery Channel are similar to the MCR jetties in length and purpose; however, they have steeper side slopes (2:1 versus 3:1) and narrower top widths ( 10.5 versus $16 \mathrm{ft}$ ). Both factors appear to increase the time required for construction (Seward ${ }^{1}$; Shaw ${ }^{2} ; \mathrm{Smith}^{3}$ ). Steeper side slopes reduce the volume of stone required for construction, but make keying in the block-shaped armor stone during placement more difficult. Shallow water at Packery Channel and at the MCR further increases the difficulty of building steeper sides. The narrow top width at Packery Channel provided less room for maneuvering a small crane and dump trucks along the top of the partially completed jetties, also increasing construction time.

\footnotetext{
1 Personal communication, Jack Seward, Luhr Brothers, Inc., Project Superintendent, 28 December 2006.

2 Personal communication, William Shaw, Luhr Brothers, Inc., Vice President, 21 December 2006.

3 Personal communication, Andrew N. Smith, U.S. Army Engineer District, Galveston, Resident Engineer, 21 December 2006.
} 


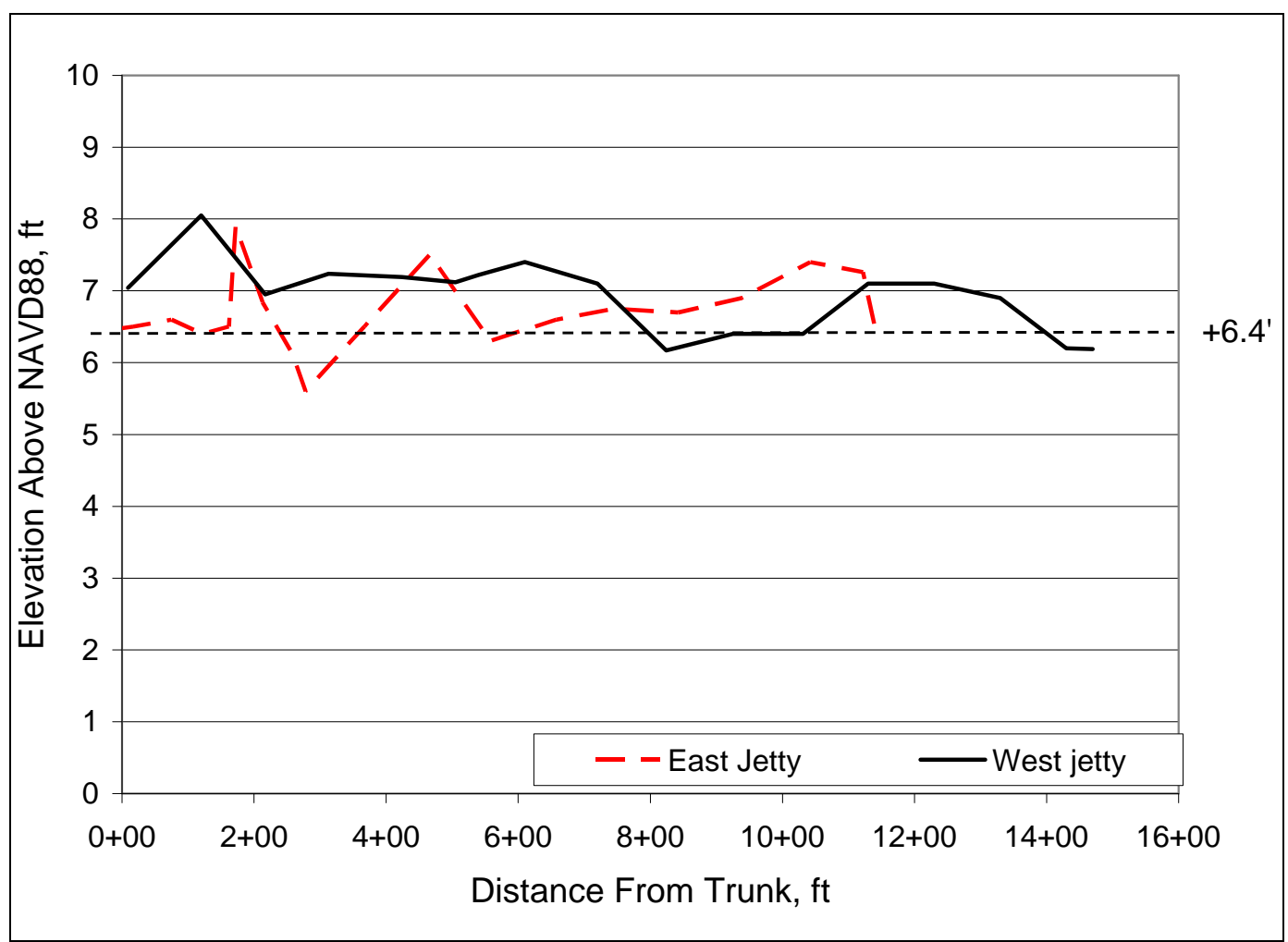

Figure 59. 2007 crest elevation of MCR jetties.

Based on experience constructing other jetties on the Texas coast, specification of a minimum crest width of $16 \mathrm{ft}$ is recommended to accommodate land-based construction. In addition to structure-geometry factors such as side slopes and crest width, construction time and cost may be increased by a moving scour hole that forms at the tip of the jetty and progresses seaward during construction. The scour should be anticipated during design to avoid unexpected over-runs in stone quantities during construction. An advantage of filling the scour hole during construction is the additional resilience to scour provided by placing stone deeper than specified.

\section{Surge analysis}

The Flood Insurance Study (FIS) for Matagorda County (Federal Emergency Management Agency (FEMA) 1984) provides an estimate of storm surge elevation for various return periods. Table 12 compiles storm surge elevations reported in the FIS. For comparison, surges associated with several notable storms recorded by the NOAA tide station at the Galveston Pleasure Pier (sta 8771510) are listed in Table 13. Note that this table does not necessarily include all peak events because water level gauges are commonly damaged and become nonfunctional during severe storms. 
Table 12. Predicted storm surge elevations (from FEMA 1984).

\begin{tabular}{|l|l|l|l|}
\hline \multicolumn{4}{|c|}{ Stillwater Elevation, ft (NAVD88) } \\
\hline 10 -year & 50 -year & 100 -year & 500 -year \\
\hline+3.5 & +6.1 & +6.9 & +8.5 \\
\hline
\end{tabular}

Table 13. Measured surge elevations of selected storms.

\begin{tabular}{|l|l|l|}
\hline Year & Storm & $\begin{array}{l}\text { Surge Elevation, ft } \\
\text { (NAVD88) }\end{array}$ \\
\hline 1983 & Hurricane Alicia & 8.3 \\
\hline 1961 & Hurricane Carla & 8.3 \\
\hline 2003 & Hurricane Claudette & 6.8 \\
\hline 1998 & Tropical Storm Frances & 5.2 \\
\hline
\end{tabular}

FEMA-predicted storm surge (Table 12) appears low if compared with measurements taken during recent storms (Table 13). For example, the 100-year predicted surge elevation of $6.9 \mathrm{ft}$ NAVD88 has been nearly met or exceeded (at Galveston) by three storms since 1961. The 500-year prediction has nearly been exceeded twice. The values predicted by FEMA possibly represent lower limits because they were calculated prior to the development of more accurate modern numerical models. Also, FEMA predictions do not include wave set-up, so they are expected to be lower than measurements obtained at a nearshore tide gauge.

\section{Wave analysis}

\section{Offshore waves}

Hindcast wave histories from WIS sta 54 (28.33으, $\left.96.00^{\circ} \mathrm{W}\right)$ and WIS sta $57\left(28.42^{\circ} \mathrm{N}, 95.75^{\circ} \mathrm{W}\right.$ ) (Tracy 2004) were analyzed to estimate the probable significant wave height for the 50 -year return period. This wave height has a 2 percent chance of being equaled or exceeded in any given year and a 64 percent chance of being equaled or exceeded in 50 years. Both stations are located at the 70-ft-depth contour and have a calculated wave record of 20 years (1980-1999).

Data from the two WIS stations were analyzed to determine the extreme wave conditions for the 50-year return period. The 20-year data sets were sorted to calculate the maximum wave height occurring during storms. Storms were defined as any event during which the wave height exceeded 
$13.2 \mathrm{ft}$ at the WIS stations. This criterion was met by 28 storms at WIS sta 54 and 25 storms at WIS sta 57. The three additional events at WIS sta 54 had wave heights that were only slightly larger than $13.2 \mathrm{ft}$. The record at WIS sta 57 had wave heights slightly lower than $13.2 \mathrm{ft}$ for those same storms. The maximum wave height, associated period, and direction during the storms are plotted in Figures 60, 61, and 62, respectively. (The three additional storms at WIS sta 54 are not displayed in these figures.)

The offshore significant wave height for the 50-year return period is summarized in Table 14. Wave period and direction were extracted from the wave record for the largest recorded waves.

Wave heights from each station were then fit to a Weibull distribution to determine the probable extreme wave height for the 50 -year return period. The resultant distributions are shown in Figures 63 and 64.

Weibull distributions of the data from both WIS sta 54 and 57 indicate approximately the same 50-year return period wave at the 70-ft-depth contour. As discussed in the next paragraph, these offshore statistics were transformed to the depth near the toe of the proposed jetty to determine hydraulic stability of the structure.

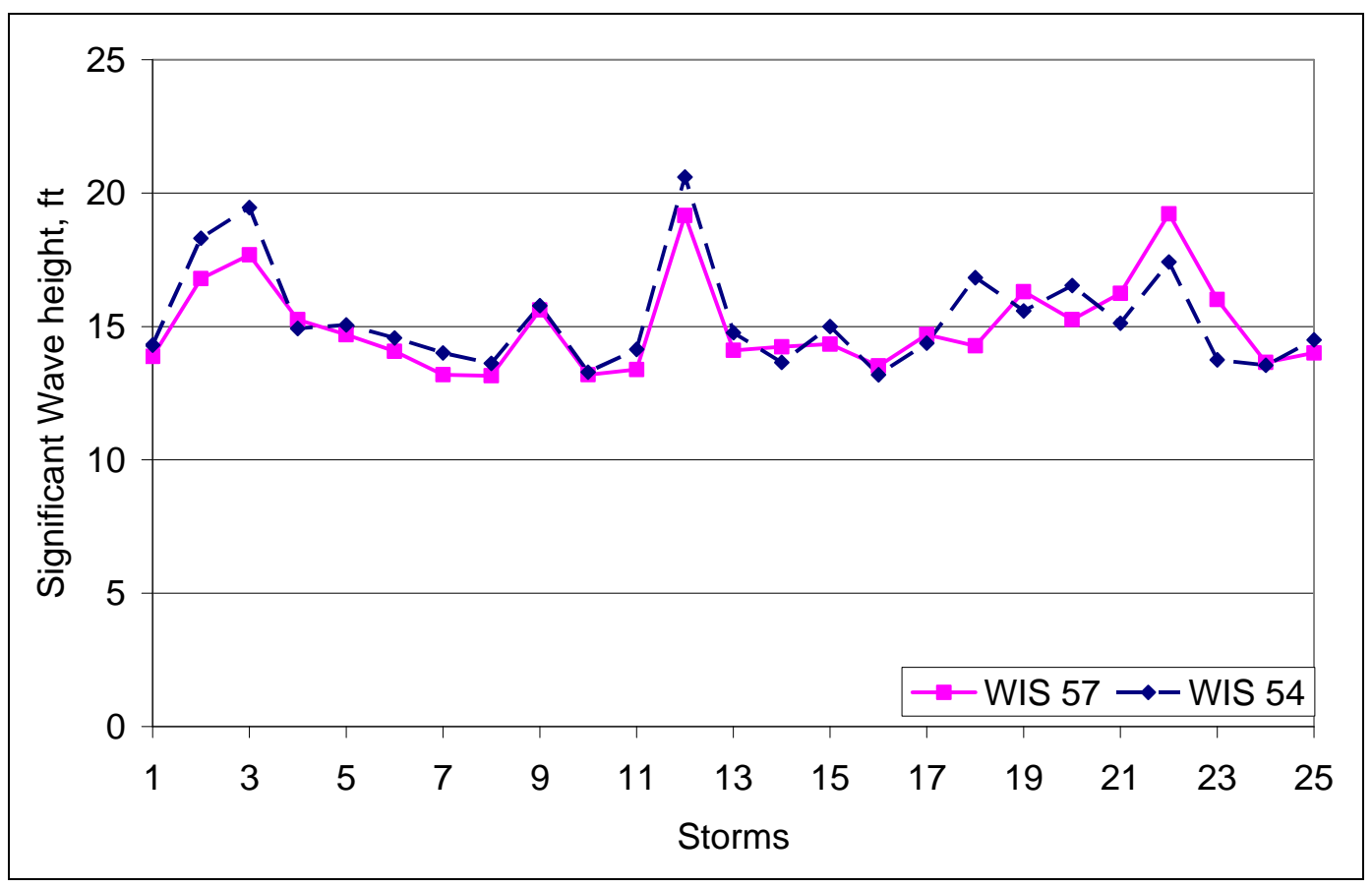

Figure 60. Maximum significant wave height during identified storms. 


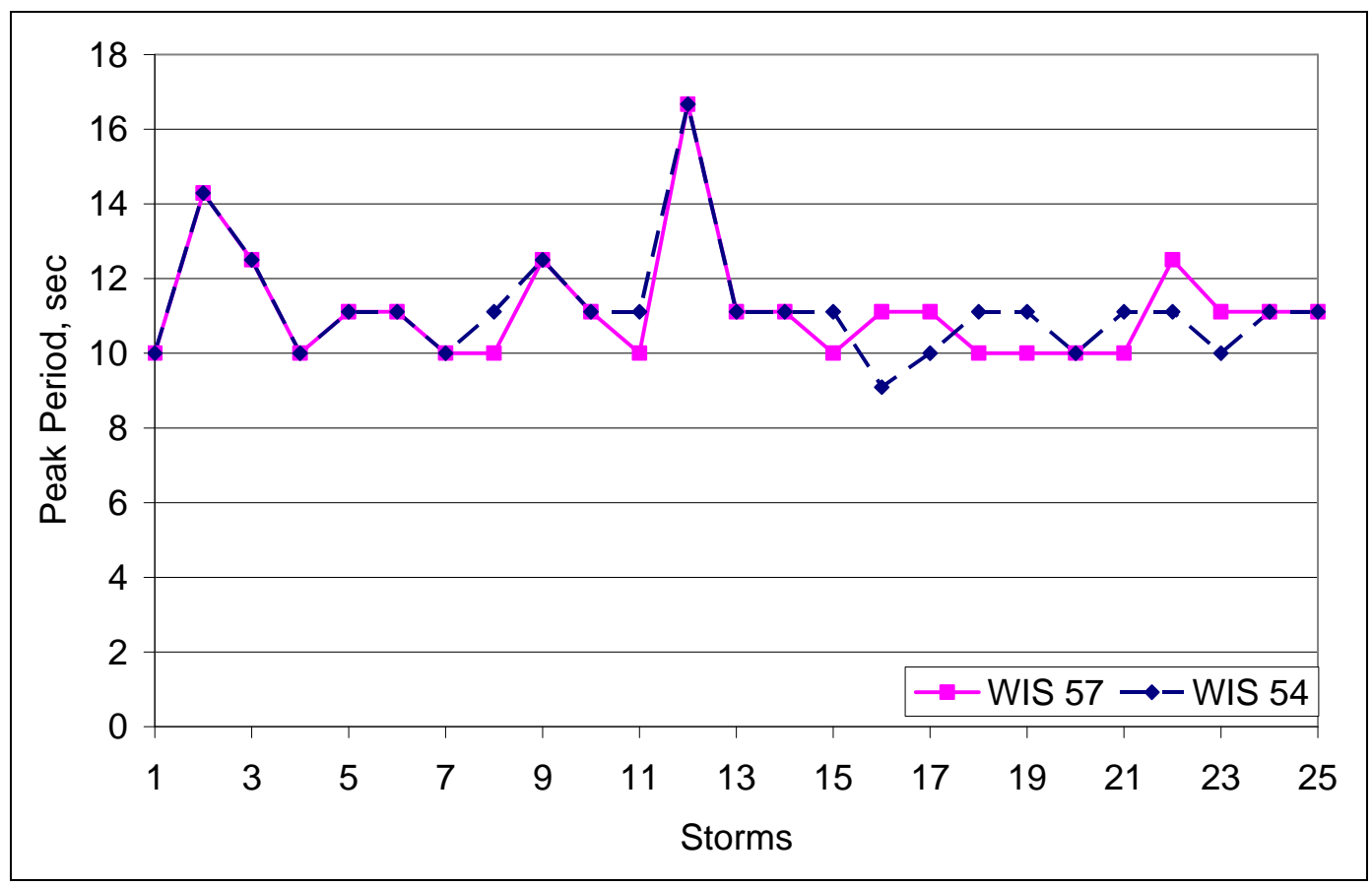

Figure 61. Peak period during identified storms.

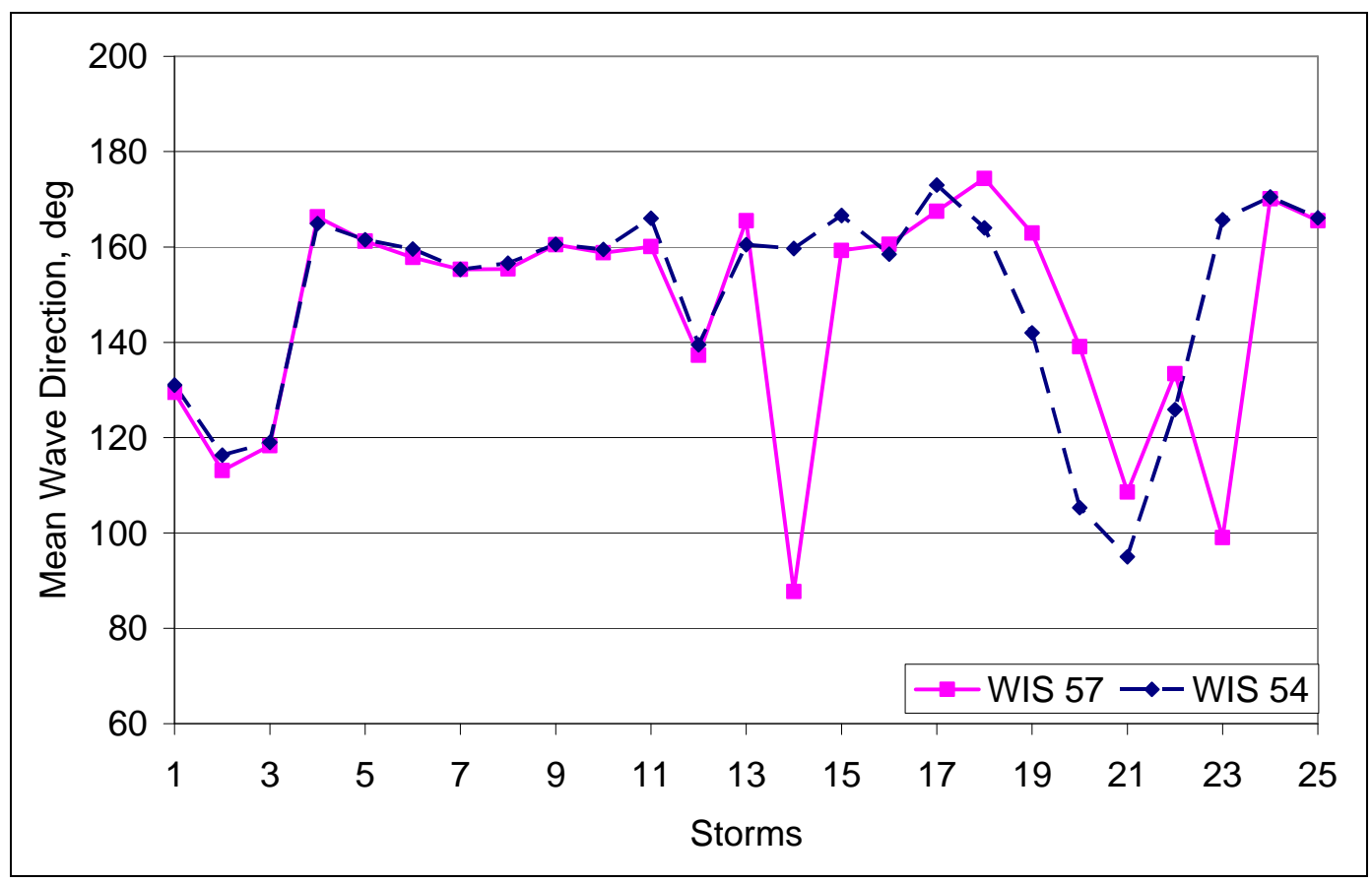

Figure 62. Mean wave direction during identified storms. 
Table 14. 50-year return period wave conditions at WIS sta 54 and 57.

\begin{tabular}{|l|l|l|l|}
\hline WIS sta & $H_{s}, \mathrm{ft}$ & $T_{p}$, sec & Direction, deg \\
\hline WIS sta 54 & 20.7 & 16.7 & 140 \\
\hline WIS sta 57 & 20.0 & 16.7 & 140 \\
\hline
\end{tabular}

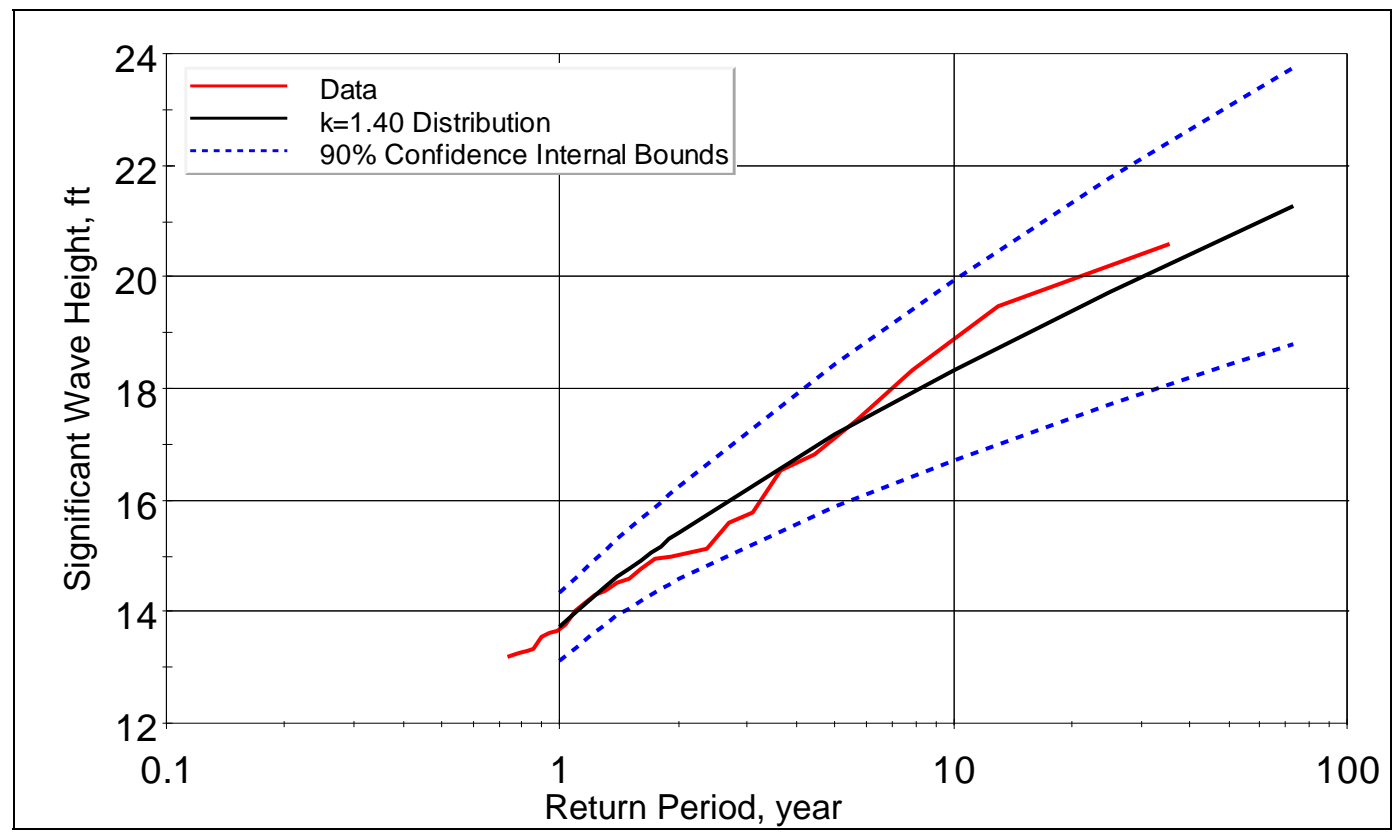

Figure 63. Extreme wave height analysis of data from WIS sta 54.

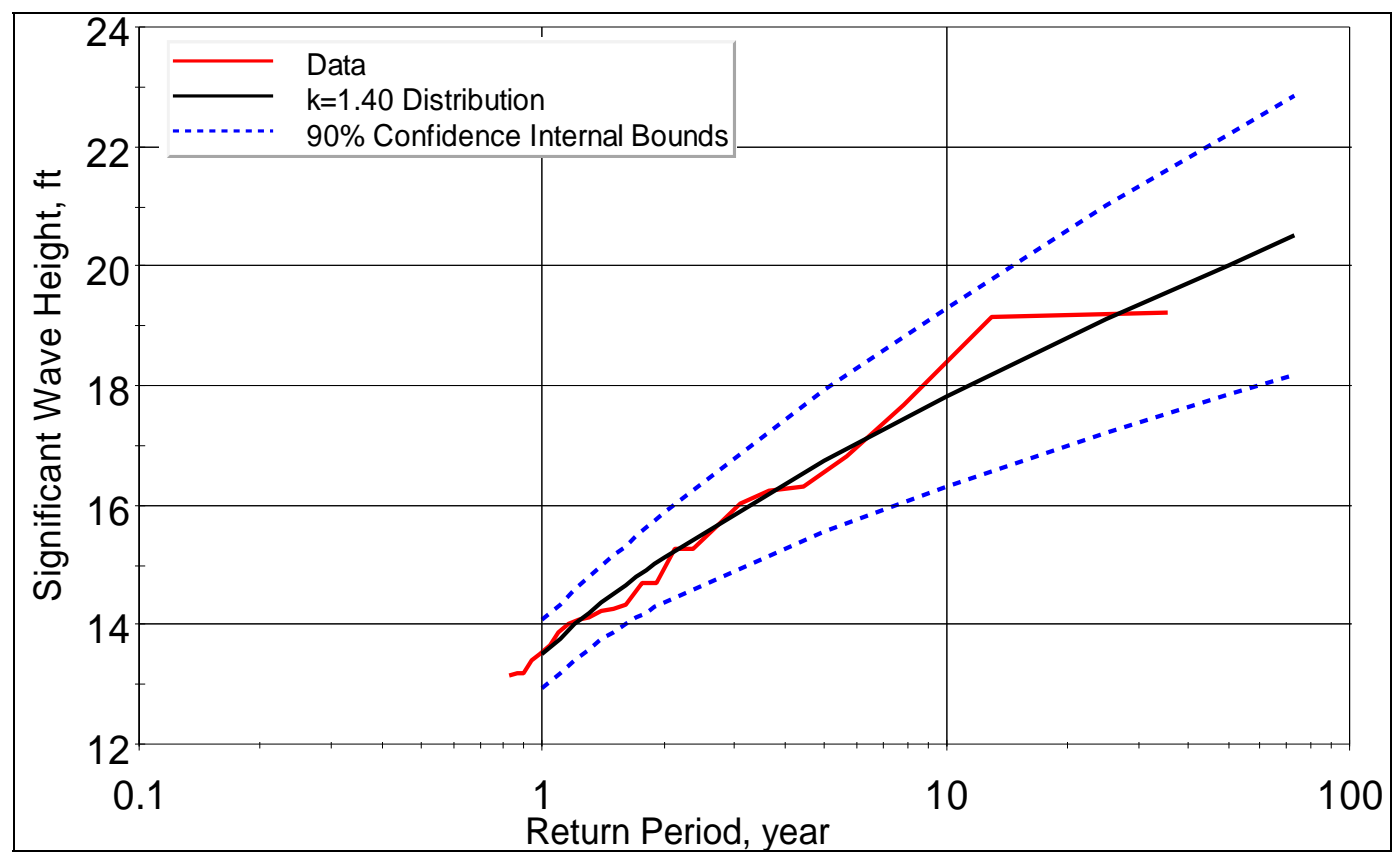

Figure 64. Extreme wave height analysis of data from WIS sta 57. 


\section{Wave transformation}

Waves were transformed from the 70-ft-depth contour to the toe of the jetty using the Steady-State Spectral Wave Model (STWAVE) (Smith et al. 2001). STWAVE is a finite-difference model of the wave action balance equation. A bathymetric grid consisting of 65,116 cells was developed based on data available from the National Geophysical Data Center originally collected in 1938 and on nearshore data collected in December 2006 as part of this study. The grid extended offshore to the approximate 70-ftdepth contour coincident with the WIS stations.

Nearshore waves at the proposed jetty were calculated as a function of water level from - 1.6 to +8.2 ft (NAVD88) and the 50-year offshore waves listed in Table 14. Only waves calculated from the WIS sta 57 data are plotted. The results are the same from both WIS stations because the waves at the jetty toe are depth limited for all water levels. STWAVE provides the zero moment wave height $\mathrm{H}_{\mathrm{m} 0}$ at each cell (Smith et al. 2001). This wave is quantitatively similar to the significant wave height $\mathrm{H}_{\mathrm{s}}$.

If depth-limited breaking is occurring, the Rayleigh distribution is no longer valid, requiring application of a different method to determine statistical wave heights. Battjes and Groenendijk (2000) present an empirical method to predict various statistical wave heights for shallowwater breaking waves as a function of zero moment wave height, nearshore slope, and local water depth as input. That method is applied here to determine the 1 percent exceedance wave height, $\mathrm{H}_{1 \%}$, for input to the Hudson stone stability equation. Figure 65 plots nearshore $\mathrm{H}_{\mathrm{m} 0}$ and $\mathrm{H}_{1 \%}$ as a function of water level for the offshore waves listed in Table 14.

As illustrated in Figure 65, the FEMA (1984) 50-year storm surge (6.1ft NAVD88) coincides with a significant local breaking wave height of approximately $10 \mathrm{ft}$. The associated wave height exceeded 1 percent of the time is approximately $13 \mathrm{ft}$. 


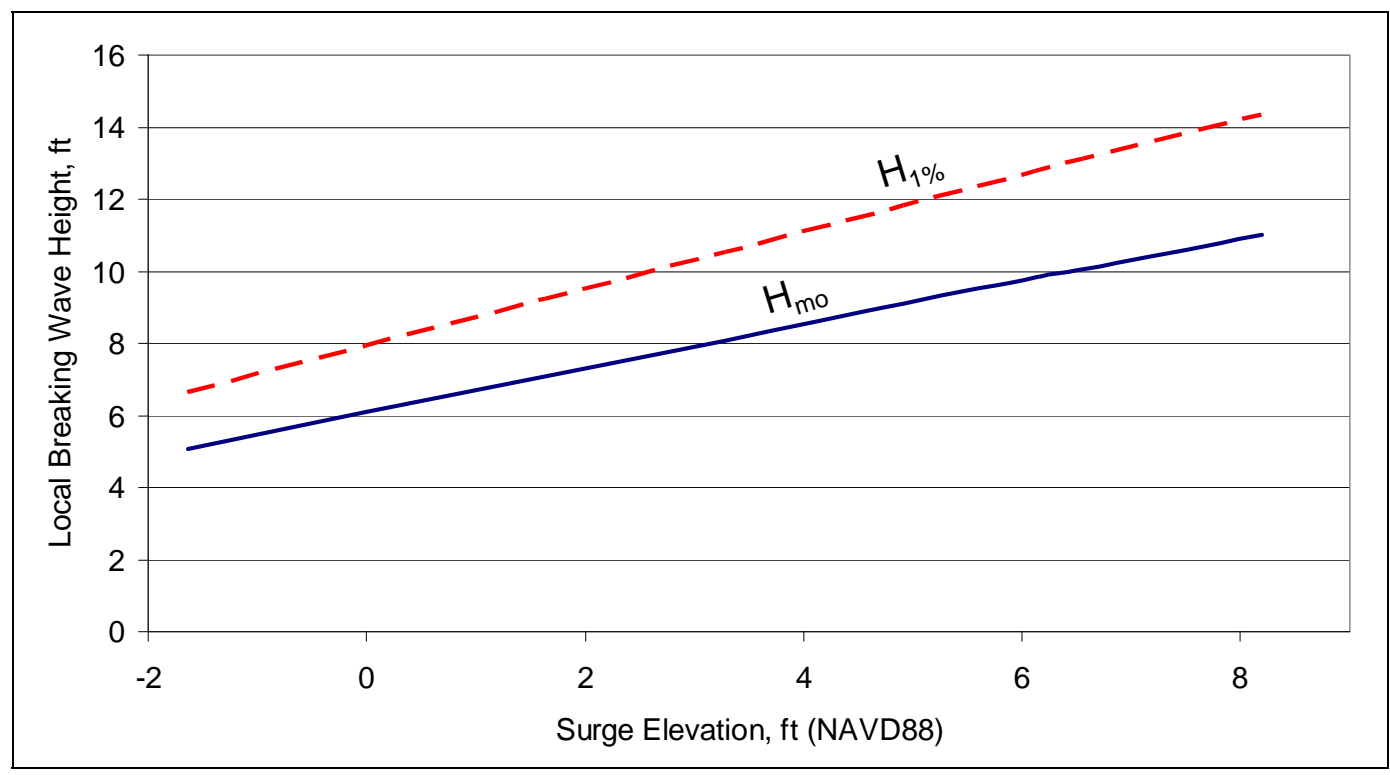

Figure $65 . H_{s}$ and $H_{1 \%}$ at jetty toe as function of storm surge.

\section{Wind-blown sand}

Wind-blown transport of sand is significant at Texas beaches and contributes to infilling of navigation channels. The Mustang Island Fish Pass inlet near Corpus Christi, TX, closed completely due in part to windblown transport only 8 years after opening and had shoaled significantly before complete closure (Kraus and Heilman 1997; Davis and Zarillo 2003) (Figure 66). As listed in Table 11, typically, the landward sections of jetties along the Texas Gulf Coast have crest elevations lower than or equal to the seaward sections. Lower crest elevation on the land sections more readily allows movement of sand into the navigation channel by windblown and swash-zone transport and by overwash during storms. Recent construction of a sediment-training structure at the MCR included a steel sheet pile along the centerline in an effort to prevent sediment transport through the structure. After about 18 months, sand filled to the top of the structure and subsequently buried it (Figure 67). 


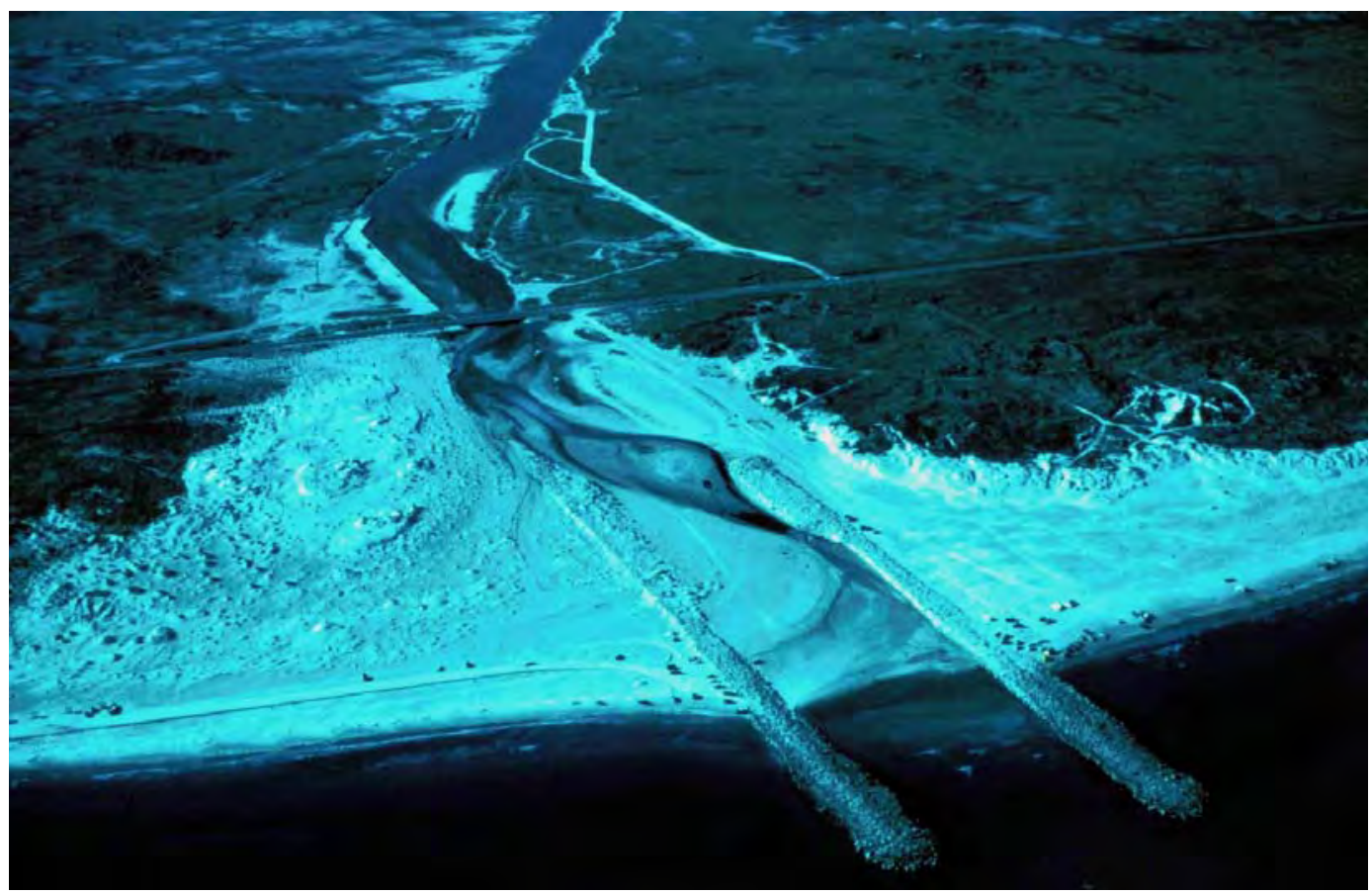

Figure 66. Aerial photograph of Fish Pass, TX (photograph: Davis and Zarillo 2003).

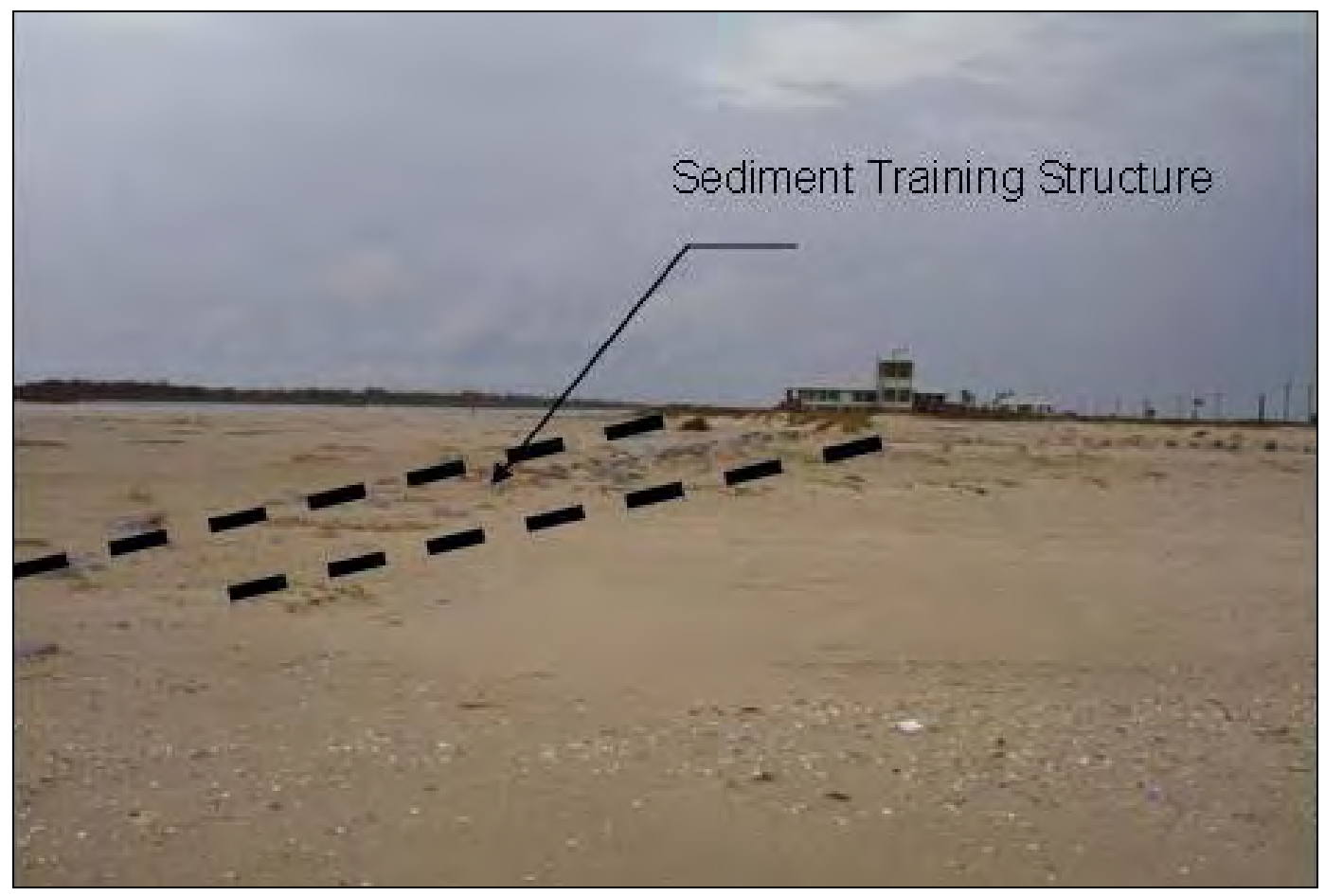

Figure 67. Photograph of buried sediment-training structure (January 2007). 


\section{Jetty sections}

Since original construction in 1983, the existing jetties at MCR have not required structural repairs or maintenance and provide a confident starting point for developing the cross section of the proposed new west jetty. A key modification consists of raising the crest elevation of the landward section to promote control of wind-blown transport and overwash during storms. The crest elevation of the landward section of the new jetty is therefore increased from 6.4 to $8 \mathrm{ft}$ NAVD88. Table 15 summarizes the proposed cross-section details for the three-section jetty design summarized in Figure 68.

Table 15. Summary of proposed cross-section details.

\begin{tabular}{|l|l|l|l|l|}
\hline Sections & Crest Width, ft & Side Slope & $\begin{array}{l}\text { Crest Elevation } \\
\mathrm{ft} \text { (NAVD88) }\end{array}$ & $\begin{array}{l}\text { Subgrade Elevation } \\
\mathrm{ft} \text { (NAVD88) }\end{array}$ \\
\hline Land & 16 & $3: 1$ & +8 & -3 \\
\hline Trunk & 16 & $3: 1$ & +6.4 & Varies from -3 to -8 \\
\hline Head & 16 & $3: 1$ & +6.4 & -8 \\
\hline
\end{tabular}

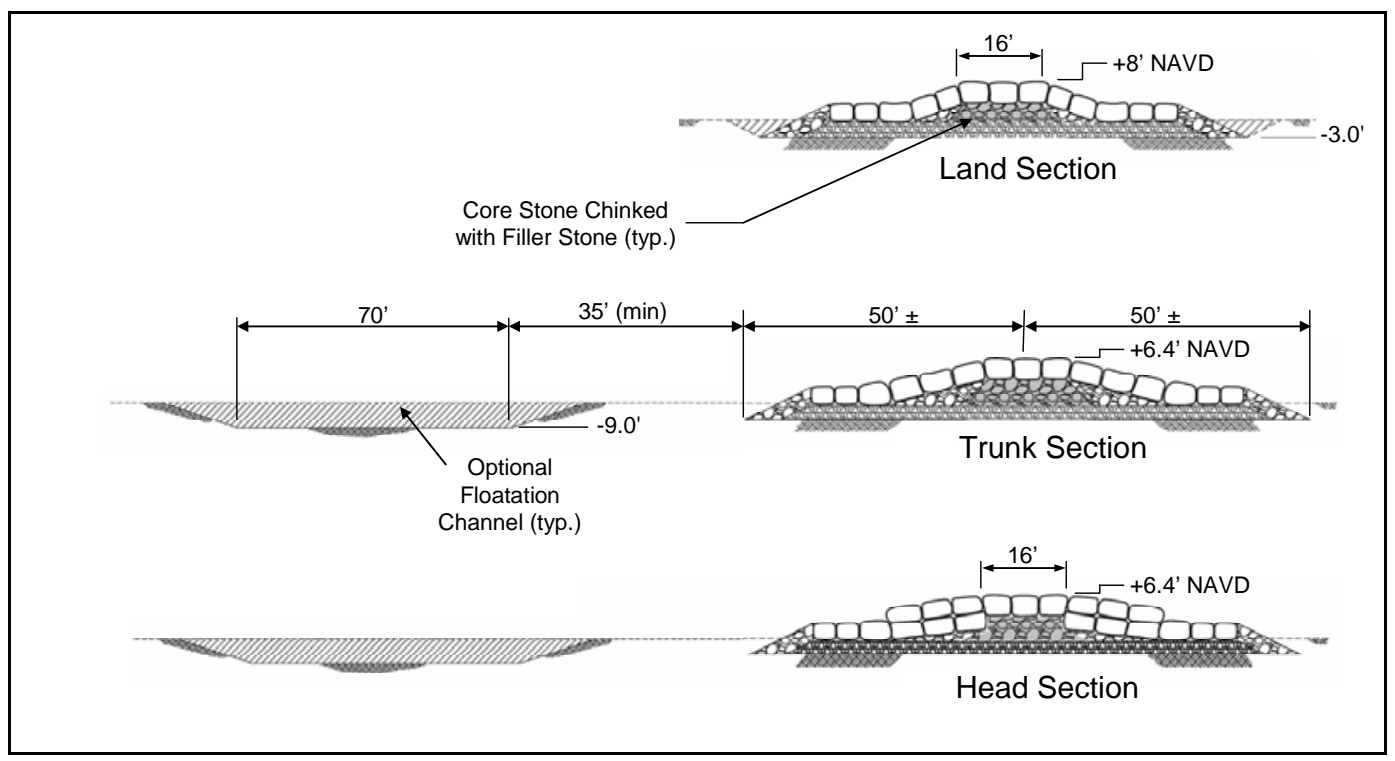

Figure 68. Proposed preliminary jetty cross section layout.

\section{Jetty stability}

Hydraulic instability of rubble-mound structures typically occurs if the forces of waves acting on the structure and/ or scour induce excessive displacement of the armor stone. The Hudson and the van der Meer equations were both applied in this study to determine the median 
required armor stone weight, $\mathrm{W}_{50}$. Potential reductions were then calculated to determine the minimum allowable armor stone weight for consideration during subsequent value-engineering and design optimization that are not included here.

\section{Hudson's approach}

Hudson developed an empirical equation (Equation 4) relating armor stone weight to wave height based primarily on small-scale model testing conducted at the U.S. Army Engineer Waterways Experiment Station in the 1950s and 1960s (Shore Protection Manual 1984):

$$
\mathrm{W}_{50}=\frac{\gamma_{\mathrm{s}} \mathrm{H}^{3}}{\mathrm{~K}_{\mathrm{D}}\left(\frac{\gamma_{\mathrm{s}}}{\gamma_{\mathrm{w}}}-1\right)^{3} \cot (\alpha)}
$$

where:

$$
\begin{aligned}
\gamma_{\mathrm{s}} & =\text { unit weight of the stone } \\
\mathrm{H} & =\text { design wave height } \\
\mathrm{K}_{\mathrm{D}} & =\text { empirically determined stability coefficient } \\
\gamma_{\mathrm{w}} & =\text { unit weight of water } \\
\cot (\alpha) & =\text { slope of the structure }
\end{aligned}
$$

In application of the Hudson equation, a relatively conservative stability coefficient value of 2 was selected for the entire structure assuming blockshaped cover stone. It may be appropriate to apply a larger stability coefficient for either the head or trunk, but those cases were not considered for this preliminary analysis. Hudson's approach does not explicitly account for wave period or storm duration, nor does it account for reduction in wave force as the structure is overtopped. The $\mathrm{H}_{1 \%}$ wave heights illustrated in Figure 65 were applied as the design wave height. The Shore Protection Manual (1984) and the Coastal Engineering Manual (Headquarters, USACE 2002) recommend either $\mathrm{H}_{\mathrm{s}}$ or $\mathrm{H}_{10 \%}$ be applied as the design wave height. Consideration of exposure to breaking waves prompted application of the more conservative $\mathrm{H}_{1 \%}$. Figure 69 plots the cover stone weight and $\mathrm{H}_{1 \%}$ versus water level based on $\gamma_{\mathrm{s}}=165 \mathrm{pcf}$, the typical minimum unit weight of the granite armor stone traditionally placed on jetties in Texas. 


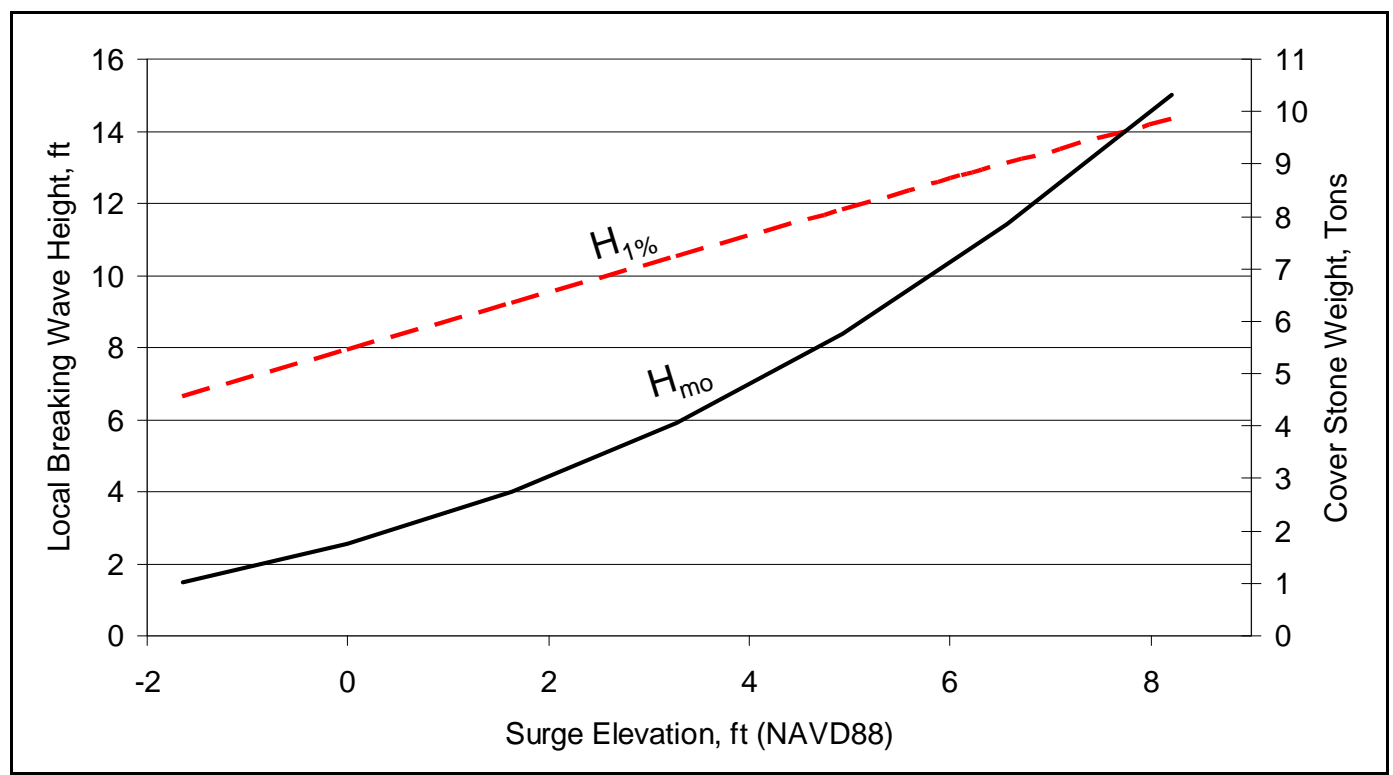

Figure 69. Armor stone weight calculated with Hudson equation.

van der Meer's approach

The approach of van der Meer, as presented in the Coastal Engineering Manual (Headquarters, USACE 2002) and the Manual on the Use of Rock in Hydraulic Engineering (CUR/ RWS 1995), allows for consideration of wave steepness, storm duration, and permeability of the structure.

Equation 5 was applied for plunging waves, and Equation 6 was applied for surging waves:

$$
\begin{gathered}
\frac{\mathrm{H}_{\mathrm{s}}}{\Delta \mathrm{D}_{\mathrm{n} 50}}=6.2 * \mathrm{P}^{0.18}\left(\frac{\mathrm{S}_{\mathrm{d}}}{\sqrt{\mathrm{N}}}\right)^{0.2} \xi_{\mathrm{m}}^{-5} \\
\frac{\mathrm{H}_{\mathrm{s}}}{\Delta \mathrm{D}_{\mathrm{n} 50}}=1.0 * \mathrm{P}^{-0.13}\left(\frac{\mathrm{S}_{\mathrm{d}}}{\sqrt{\mathrm{N}}}\right)^{0.2}[\sqrt{\cot (\alpha)}] \xi_{\mathrm{m}}^{\mathrm{P}}
\end{gathered}
$$

The nearshore significant wave height approximated as $\mathrm{H}_{\mathrm{m} 0}$ from Figure 65 was applied instead of $\mathrm{H}_{1 \%}$ in accordance with guidance provided by van der Meer. ${ }^{1}$ Other input variables are described as follows:

$$
\begin{aligned}
\mathrm{H}_{\mathrm{S}} & =\text { significant wave height } \\
\Delta & =\text { relative buoyant density of rock }=\rho_{\mathrm{r}} / \rho_{\mathrm{w}}-1
\end{aligned}
$$

\footnotetext{
1 Personal communication. Jentse van der Meer, Consultants for Infrastructure Appraisal and Management, Head, Coastal Engineering Department, 23 March 2005.
} 


$$
\begin{aligned}
\rho_{\mathrm{r}} & =\text { mass density of rock } \\
\rho_{\mathrm{w}} & =\text { mass density of sea water } \\
\mathrm{D}_{\mathrm{n} 50} & =\text { characteristic median stone size } \\
\mathrm{P} & =\text { empirical notional permeability factor } \\
\mathrm{S}_{\mathrm{d}} & =\text { damage level } \\
\mathrm{N} & =\text { number of waves for a given event } \\
\xi_{m} & =\text { surf-similarity parameter }
\end{aligned}
$$

The surf-similarity parameter is calculated to determine if the waves are plunging or surging. The quantity $\xi_{\mathrm{mc}}$ is the critical value of the surfsimilarity parameter (Equation 7). If $\xi_{\mathrm{m}}>\xi_{\mathrm{mc}}$, the waves are considered to be surging; otherwise, the waves are plunging:

$$
\xi_{\mathrm{mc}}=\left[6.2 \mathrm{P}^{0.31} \sqrt{\tan (\alpha)}\right]^{\frac{1}{(\mathrm{P}+0.5)}}
$$

The required armor stone weights based on the van der Meer equations are plotted in Figure 70 against water level along with $\mathrm{H}_{\mathrm{m} 0}$. The required stone weight based on the van der Meer equations is 16 to 47 percent less than that estimated with the Hudson equation.

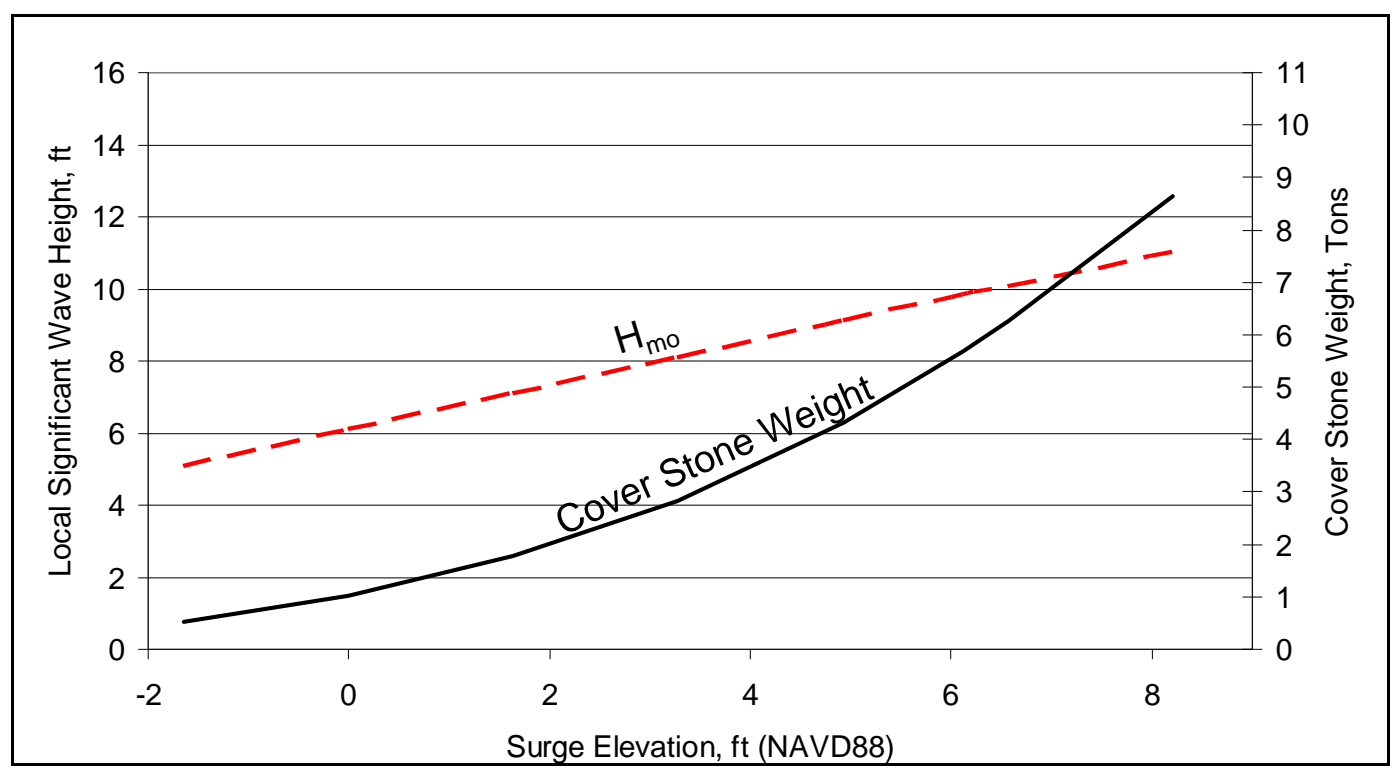

Figure 70. Armor stone weight calculated with van der Meer equations. 
Reductions for overtopped and submerged jetties

CUR/ RWS (1995) describes calculation methods for reductions in size of the armor stone for situations in which the structure is overtopped (by waves) or submerged. The forces exerted by waves breaking on a structure are reduced as the water level rises and successively less of the wave breaks directly on the seaward slope of the jetty. A greater reduction is allowed for a submerged jetty. Overtopping occurs if wave run-up exceeds the freeboard of the structure $\mathrm{R}_{\mathrm{c}}$. CUR/ RWS (1995) recommends a reduction factor $\mathrm{r}_{\mathrm{D}}$ for the nominal mean armor stone diameter, $\mathrm{D}_{\mathrm{n} 50 \text {, }}$ calculated according to (Equation 8):

$$
\mathrm{r}_{\mathrm{D}}=\frac{1}{\left(1.25-4.8 \mathrm{R}_{\mathrm{P}}^{*}\right)}
$$

where:

$$
\begin{aligned}
& \mathrm{R}_{\mathrm{P}}^{*}=\frac{\mathrm{R}_{\mathrm{c}}}{\mathrm{H}_{\mathrm{s}}} \sqrt{\frac{\mathrm{S}_{\mathrm{p}}}{2 \pi}}=\text { non-dimensional freeboard parameter } \\
& \mathrm{S}_{\mathrm{p}}=\text { peak wave steepness calculated using nearshore } \mathrm{H}_{\mathrm{m} 0}
\end{aligned}
$$

CUR/ RWS (1995) presents a method by van der Meer for determining the stability of a submerged jetty as a function of the relative crest height, $d / h$, the damage level, $\mathrm{S}_{\mathrm{d}}$, and the spectral stability number $\left(\mathrm{N}_{\mathrm{S}}^{*}\right.$, Equation 10$)$ :

$$
\begin{gathered}
\frac{\mathrm{d}}{\mathrm{h}}=\left(2.1+0.1 \mathrm{~S}_{\mathrm{d}}\right) \exp \left(-0.14 \mathrm{~N}_{\mathrm{S}}^{*}\right) \\
\mathrm{N}_{\mathrm{S}}^{*}+\left(\frac{\mathrm{H}_{\mathrm{s}}}{\Delta \mathrm{D}_{\mathrm{n} 50}}\right)\left(\frac{\mathrm{H}_{\mathrm{S}}}{\mathrm{L}_{\mathrm{P}}}\right)^{-1 / 3}
\end{gathered}
$$

where:

$$
\begin{aligned}
\mathrm{d}= & \text { crest height of the structure } \\
\mathrm{h}= & \text { water depth at the structure } \\
\mathrm{L}_{P}= & \text { local wave length determined using the linear wave theory } \\
& \text { dispersion relationship }
\end{aligned}
$$


The reductions are applied to the heavier of the predicted nominal armor stone weights from the Hudson and van der Meer equations. Figure 71 plots the reduced nominal cover armor weight against the surge elevation. These reductions were not applied for the preliminary design summarized herein, but are presented for consideration during subsequent design optimization or value-engineering phases by the Galveston District.

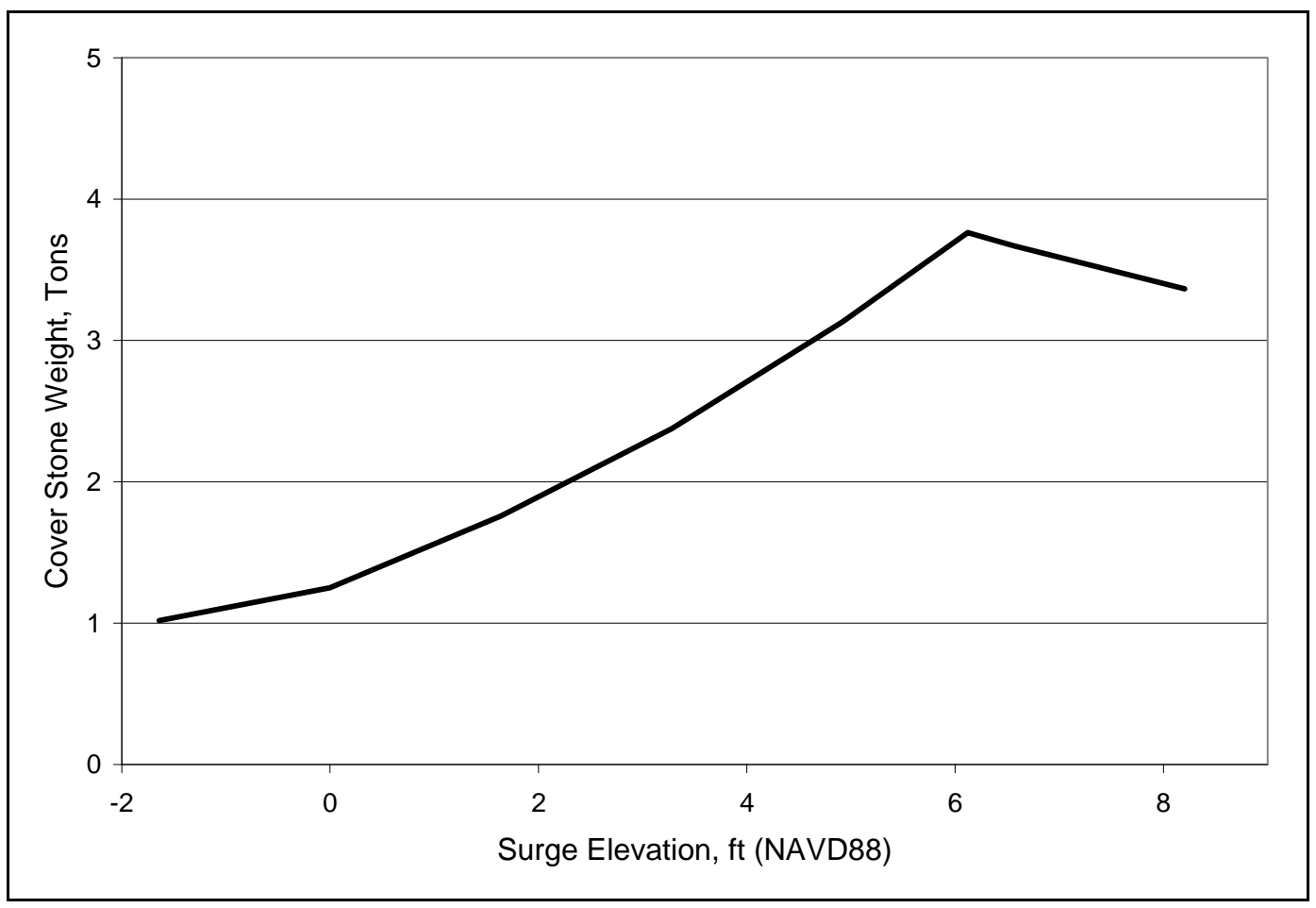

Figure 71. Minimum armor stone weight using calculated reductions for inundation of structure.

\section{Suggested jetty cross section}

The stability analysis described in the preceding section indicates that it might be possible to place smaller armor stone than originally estimated. The fact that no significant damage to the existing jetties has occurred further supports that conclusion. However, more detailed analysis should be conducted during final design before the reductions are applied. As shown in Table 11, the cover stone weight for shorter jetties (i.e., MCR, Packery Channel, Mansfield Pass) has typically been 10 tons, although the east jetty at the MCR has an armor stone weight of up to 18 tons. Given the stable history of these projects and considering the stability calculations presented in Figures 69 through 71, 10 tons was selected as the preliminary armor stone weight (assuming block-shaped armor stones). 
As has typically been done on Texas jetties, the armor stone weight can likely be reduced in the trunk and land sections, providing further reductions in cost. Stability analyses similar to the one presented here should be considered for multiple sections along the jetty. Sections of the jetty in shallower water will be exposed to smaller breaking wave heights, possibly justifying lighter armor stone.

Based on constructibility considerations, the side slope of the jetty was selected as 3H:1V. The flatter side slope also reduces the wave forces acting on the jetty, thereby increasing hydraulic stability. The crest width should be about $16 \mathrm{ft}$ to make land-based construction more feasible. Easier land-based construction should result in decreased construction time and cost. As depicted on Figure 68, an optional 70-ft-wide flotation channel dredged adjacent the new jetty should be considered to provide barge access for construction. Note that reach limitations of a typical barge-mounted crane would prevent construction of the entire cross section from the flotation channel. However, despite requiring some double handling of the stone, partial marine-based construction may provide an overall cost reduction.

\section{Relative sea level rise}

Relative sea level rise (RSLR) could reduce the effectiveness of the jetty in limiting sediment transport into the navigation channel in the future. The crest of the jetty needs to be sufficiently high to prevent transport of sediment over it from both the wind and water, when the jetty might be overtopped or submerged.

Because extreme wave heights acting on the jetty are always depth limited, the extreme wave height will increase with RSLR. The preliminary armor stone weight was determined with the more conservative stability equation (Hudson equation) for waves that would occur at a water level $1.9 \mathrm{ft}$ above the FEMA-predicted 50-year level. Applying both the more conservative stability equation and the additional $1.9 \mathrm{ft}$ of freeboard provides an additional safety factor for jetty stability with respect to future RSLR. In addition, as illustrated in Figure 59, the observation that the crest elevations of the existing MCR jetties remain at or near their design elevations suggests that the subsidence component of RSLR is minimal at this site. 
Geotechnical analysis

A preliminary geotechnical analysis was performed during J anuary 2007 by Rock Engineering and Testing Laboratory, Inc. The objective of the analysis was to estimate the required offset of the jetty from the navigation and/ or temporary flotation channels to prevent slope failure. Preliminary analysis suggests a minimum offset of $35 \mathrm{ft}$ from the toe of the jetty to the bottom of the dredge cut, as shown in Figure 68. Additional analyses included bearing stability and settlement.

Based on limited soil information inferred from available Galveston District boring logs prepared prior to design of the existing MCR jetties and analysis by Turner, Collie \& Braden, Inc., and DMJ M-Harris (2002) for the sediment-training structure, bearing capacity was estimated. The estimation was found to be acceptable, and total settlement was calculated to be less than $1 \mathrm{ft}$. More detailed geotechnical data collection and analyses, including soil borings along the proposed jetty alignment, are presented in Appendix D. This investigation includes a more accurate assessment of soil properties within the original (now shoaled) channel, which would be located within the footprint of the new jetty (Figures 72 and 73).

Scour

Scour could lead to undermining and damage to the jetty. The toe apron is included to provide scour protection, but detailed analysis of the level of protection has not been performed. The configuration of the toe apron is similar to the existing structure and, as such, is expected to perform well. More detailed analysis of scour resulting from currents and waves should be included in the final design. Scour during construction often causes stone quantity overruns. A contingency for additional stone is included in the probable construction quantities to account for some of this loss. 


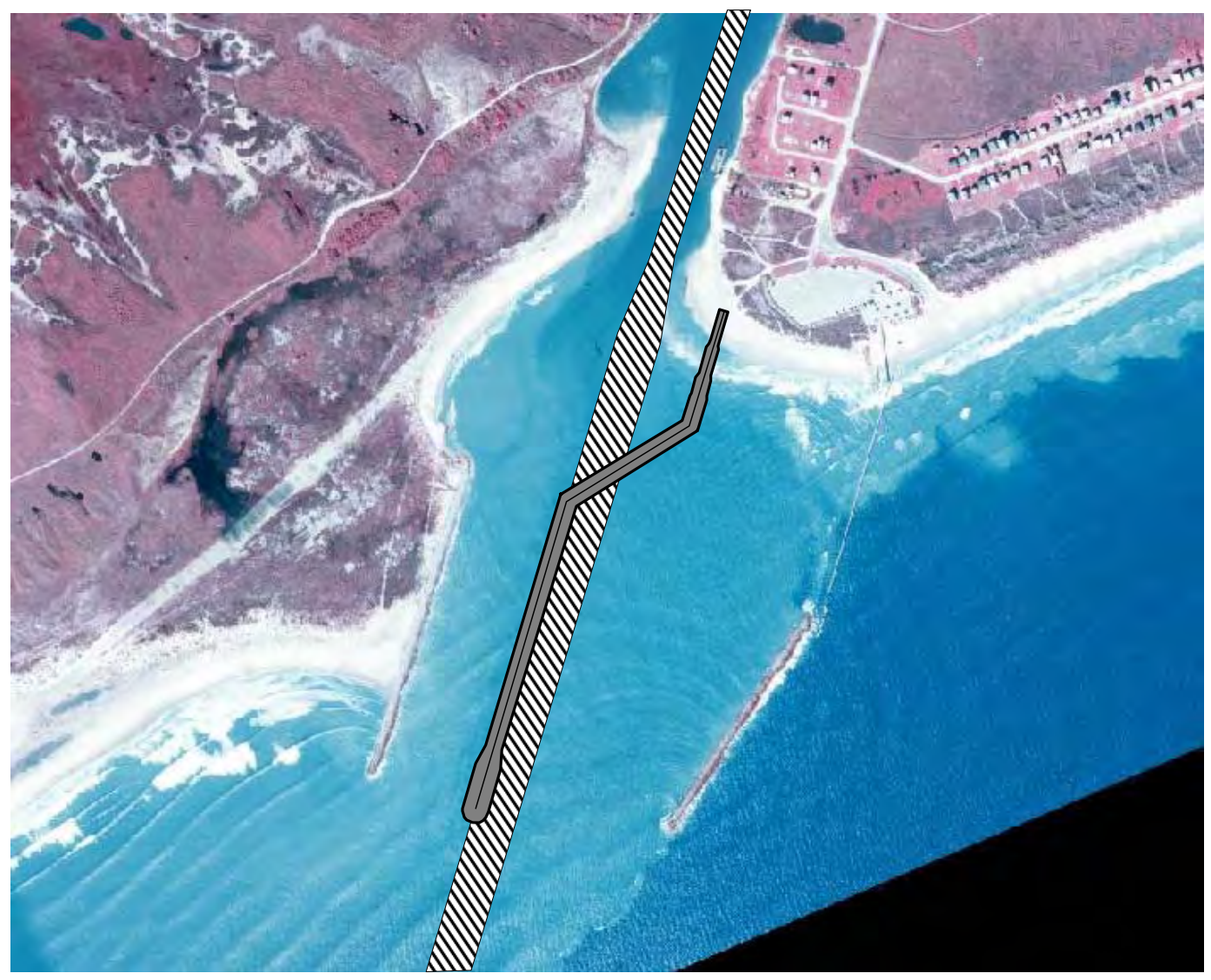

Figure 72. Plan view of location of proposed new east jetty, MCR (photograph November 2001; courtesy of Texas General Land Office).

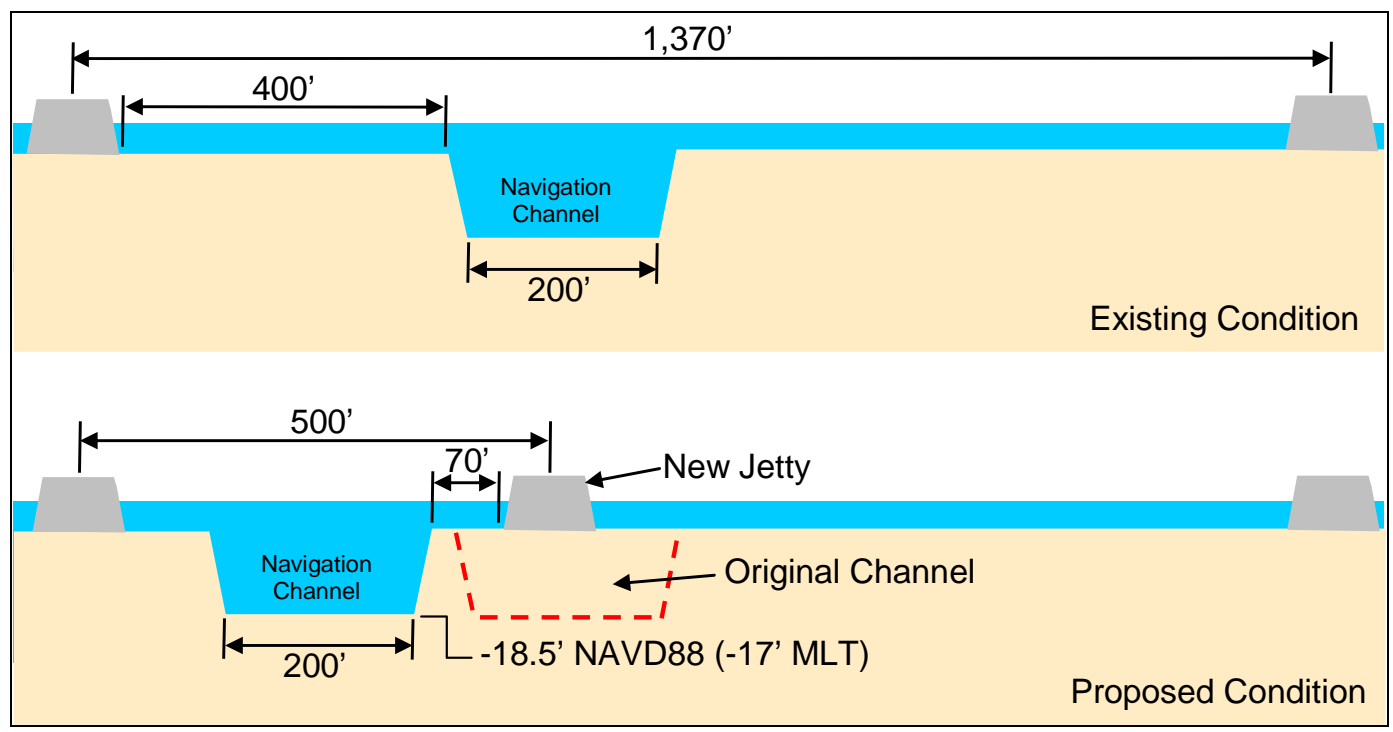

Figure 73. Cross-sectional view of proposed new east jetty, MCR. 


\section{Raising sediment-training structure}

The sediment-training structure was originally designed to divert sediment into the impoundment basin (USACE 2002, and Chapter 1 of this report). It has since been covered by sand owing to wind-blown transport and swash-zone transport alongshore. Raising the structure will reduce wind-blown sand transport into the navigation channel from the beach on the east side of the channel. Because the sediment-training structure is buried on land, detailed stability analysis of the structure was not performed. It is recommended that the existing sediment-training structure be raised $4 \mathrm{ft}$ as part of construction of the landward segment of the proposed new east jetty.

\section{Preliminary opinion of probable construction cost}

A preliminary opinion of probable construction cost was determined based on discussions with contractors and with Galveston District personnel having experience with jetty construction on the Texas coast. The presented cost includes only the construction of the jetty and does not include the final design or environmental assessment that will be required before construction. Probable construction costs are based on approximate current market costs, but could vary with supply of materials and labor, the price of fuel, economic inflation, or other unforeseen circumstances. As summarized in Table 16, the total construction cost is estimated to be approximately \$11,143,000 as of March 2007. 
Table 16. Preliminary opinion of probable construction cost.

\begin{tabular}{|c|c|c|c|c|}
\hline Item & Quantity & Unit & Unit Price (\$) & Extension (\$) \\
\hline Mobilization / Demobilization & 1 & LS & 200,000 & 200,000 \\
\hline Topo / Hydro Acceptance Surveys & 1 & LS & 75,000 & 75,000 \\
\hline Hazard (Magnetometer) Survey & 1 & LS & 30,000 & 30,000 \\
\hline Flotation Channel (Dredging to -9' NAVD88) ${ }^{1}$ & 30,000 & $\mathrm{CY}$ & 3 & 90,000 \\
\hline \multirow{2}{*}{ teng } & & & Contingencies (20\%) & 79,000 \\
\hline & & & SUBTOTAL: & 474,000 \\
\hline \multicolumn{5}{|l|}{ Jetty Construction } \\
\hline Armor Stone $(2,160$ LF) & 31,000 & Ton & 140 & $4,340,000$ \\
\hline Core Stone $(2,160 \mathrm{LF})$ & 27,600 & Ton & 63 & $1,739,000$ \\
\hline Blanket Stone $(2,160$ LF) & 34,900 & Ton & 58 & $2,025,000$ \\
\hline Filler Stone $(2,160$ LF) & 4,500 & Ton & 62 & 279,000 \\
\hline \multirow[t]{3}{*}{ Foundation Excavation } & 15,000 & CY & 3 & 45,000 \\
\hline & & & Contingencies (20\%) & $1,686,000$ \\
\hline & & & SUBTOTAL: & $10,114,000$ \\
\hline \multicolumn{5}{|l|}{ Raising the Existing Sediment-Training Structure } \\
\hline \multirow[t]{4}{*}{ 1- to 3-ton Stone (540 LF) } & 6,600 & Ton & 70 & 462,000 \\
\hline & & & Contingencies (20\%) & 92,400 \\
\hline & & & SUBTOTAL: & 554,400 \\
\hline & & & TOTAL & $11,143,000$ \\
\hline \multicolumn{5}{|c|}{$\begin{array}{l}\text { Notes: } \\
\text { LS = lump sum; CY = cubic yard; LF = linear foot. } \\
\text { Dredging and stone quantities based on bathymetry collected by Dimco, Inc., under contract with ERDC-CHL, } \\
\text { on } 14-15 \text { December } 2006 \text { and by HDR on } 4 \text { January } 2007 \text {. } \\
\text { Costs for dredging navigation channel and modifications to aids to navigation are not included. } \\
\text { Cost for optional concrete cap as jetty walkway is not included and would likely add approximately } \$ 75,000 \text { to } \\
\text { total cost. } \\
1 \text { Contingency of } 75 \% \text { was added to quantity for dredging flotation channel, for re-dredging and maintenance } \\
\text { during construction. Unit cost is based on mechanical excavation and side casting. }\end{array}$} \\
\hline
\end{tabular}




\section{Summary and Findings}

This study benefited from data collection and previous studies performed by ERDC for the Galveston District, Operations Division. The previous investigations examined the coastal and inlet processes at the site and developed a staged plan for incremental improvement. The present study continued and completed previous work in arriving at a recommended permanent structural solution. This study was conducted in a multidisciplinary approach involving review of the engineering and geologic literature; review of inlet stability and jetty construction experience at Texas Inlets; a bathymetric survey; shoreline position analysis performed in a GIS; long-term (20 years) shoreline change numerical modeling and estimation of required mechanical sediment bypassing; numerical modeling of inlet processes - the waves, circulation, sediment transport, and short-term (month) channel infilling; and development of a preliminary design for the cast jetties, including an estimate of construction cost.

Present Federal Administration policy does not give priority to maintenance of shallow-draft navigation channels. Therefore, the local costsharing sponsor requested the Galveston District develop a design for a permanent structural solution that would reduce dredging frequency while maintaining a reliable channel. The solution would be constructed through congressional authorization and appropriation apart from the normal Galveston District operation and maintenance budget.

\section{Findings}

The existing jetty configuration at the MCR is inadequate for maintaining a reliable navigation channel. The jetties are too widely spaced, and the weir section on the east jetty is too long. The navigation channel and the sediment impoundment basin associated with the weir accumulate more than double the expected rate of sand. Bypassing of the impoundment basin by sand moving alongshore on its landward side during storms and times of high water creates a spit that encroaches into the navigation channel, narrowing the channel and pushing it toward the west jetty. The channel in the vicinity of the spit constricts to a minimum cross section compatible with a balance of scouring current through the inlet and sediment source from the spit. Vessels traversing the narrow and curved channel must be concerned with proximity to the west jetty as opposed to 
navigating a channel located midway between the jetties. The dredged impoundment basin poses a hazard to wade fishing, in presenting unexpected deep water close to shore. Functioning of the original engineering design was compromised by diversion of the Colorado River into Matagorda Bay, thus depriving the MCR with the river's scouring action by creating a near dead-end entrance.

The existing condition and seven alternatives were examined. The alternatives principally involved a new east jetty aligned straight out and parallel to the existing west jetty with $500 \mathrm{ft}$ between the jetties, two channel widths, and opening or non-opening of Parkers Cut and the Southwest Corner Cut. A jetty spacing of $400 \mathrm{ft}$ was also investigated but did not give notable additional benefit. A new east jetty would impound sand transported west along the east beach, thereby eliminating the spit that grows from the eastern bank and constricts the river channel. The new east jetty would afford better protection to vessels in providing greatly improved shelter from waves as compared with the present wide opening between the jetties and 1,000-ft opening at the weir.

The alternatives covered both a 150- and 200-ft-wide (bottom width) navigation channel. The 150-ft-wide channel produced a slightly increased along-channel current and is therefore preferred.

Reopening of Parkers Cut to Matagorda Bay would not be favorable to stability of the CRNC, confirming a previous study (Lin et al. 2001). Parkers Cut would promote a stronger flood current and transport sand from the entrance into the navigation channel, probably as far as the cut. An indication for this sedimentation trend can be found in Figure C16 of Appendix C, taken when Parkers Cut was open. Sand shoals are observed south and north of the cut in the CRNC.

Opening of the SW Corner Cut to connect East Matagorda Bay and the CRNC would be favorable by promoting ebb flow through the MCR. In addition, although not studied here, opening of the SW Corner Cut would reduce the current magnitude at the CRNC and GIWW intersection (Kraus and Militello 1996, 1999). 


\section{Recommendations}

From Table 9, Alts 3, 4, and 1 are recommended, in that order. These alternatives have a new east jetty located $500 \mathrm{ft}$ from the west jetty. Alt 3 and Alt 4, respectively, describe a 150-ft-wide and 200-ft-wide entrance channel, both with the SW Corner Cut open, and Alt 1 describes a 150-ftwide entrance channel, without the SW Corner Cut open. The beaches and MCR channel would be monitored for condition, and the accretion fillet between the jetties or to the east of the east jetty would be dredged for protecting the entrance channel from sand intrusion and to bypass material to the down-drift (west) beach.

After construction of the new east jetty, the navigation channel and area of the deposition basin should be dredged to provide a clean initial condition. The material should be placed on the west beach on the order of 3,000 ft or westward from the west jetty.

The existing sediment-retention structures should be raised to serve as a tie-in with land for the new east jetty. The landward portion of the jetty should be raised about $4 \mathrm{ft}$ to reduce excessive channel infilling by windblown sand and to account for RSLR, preventing swash-zone sand transport into the channel during times of high water level.

There is a trade-off in minimizing the costs of jetty stone volume and construction. It is recommended that the crest of the new east jetty be $16 \mathrm{ft}$ wide to allow easier and faster placement of stone on a more gentle structure slope.

A preliminary geotechnical analysis was done based on available information. The preliminary analysis was supplemented by a full analysis based on borings taken at the site and contained in Appendix D. 


\section{References}

Barcak, R. G., N. C. Kraus, L. Lin, E. R. Smith, D. J. Heilman, and R. C. Thomas. 2007. Navigation improvements, Mouth of the Colorado River, Texas. Proceedings, Coastal Sediments '07, ASCE, 1,502-1514.

Battjes, A. J ., and H. W. Groenendijk. 2000. Wave height distributions on shallow foreshores. Coastal Engineering 40:161-182.

Bodge, K. R., and N. C. Kraus, N.C. 1991. Critical examination of longshore transport rate magnitude. Proceedings, Coastal Sediments ‘91, ASCE, 139-155.

Brown, M. E., N. C. Kraus, and J . M. Kieslich. 2003. Regional Circulation Modeling of the Texas Coast and Inland Coastal Waters. Proceedings, 8th Estuarine and Coastal Modeling Conference, ASCE, 192-214.

Buttolph, A. M., C. W. Reed, N. C. Kraus, N. Ono, M. Larson, B. Camenen, H. Hanson, T. Wamsley, and A. K. Zundel. 2006. Two-dimensional depth-averaged circulation model M2D: Version 3.0, Report 2: Sediment transport and morphology change. Coastal and Hydraulics Laboratory Technical Report ERDC/CHL TR-06-9. Vicksburg, MS: U.S. Army Engineer Research and Development Center.

CUR/ RWS. 1995. Manual on the use of rock in hydraulic engineering. Report 169. Balkema, Rotterdam, The Netherlands: Center for Civil Engineering Research and Codes.

Davis, R. A., and G. A. Zarillo. 2003. Human-induced changes in back-barrier environments as factors in tidal inlet instability with emphasis on Florida. Coastal and Hydraulics Laboratory Technical Note CHETN-IV-57. Vicksburg, MS: U.S. Army Engineer Research and Development Center.

Federal Emergency Management Agency. 1984. Flood insurance study: Matagorda County, Texas.

Hanson, H., and N. C. Kraus. 1989. GENESIS: Generalized model for simulating shoreline change. Report 1: Technical reference. Coastal Engineering Research Center Technical Report TR CERC-89-19. Vicksburg, MS: U.S. Army Engineer Waterways Experiment Station.

Headquarters, U.S. Army Corps of Engineers. 2002. Coastal Engineering Manual. EM 1110-2-1100 (in 6 volumes). Washington, DC.

Heilman, D. J., and B. L. Edge. 1996. Interaction of the Colorado River Project, Texas, with longshore sediment transport. Proceedings, 25 $5^{\text {th }}$ Coastal Engineering Conference, ASCE, 3,309-3,322.

Jarrett, J . T. 1976. Tidal prism-inlet area relationships. General Investigation of Tidal Inlets Report 3. Vicksburg, MS: U.S. Army Engineer Waterways Experiment Station. 
J ensen, R. E. 1983. Methodology for the calculation of a shallow-water wave climate. Coastal Engineering Research Center's Wave Information Study Report 8. Vicksburg, MS: U.S. Army Engineer Waterways Experiment Station.

King, D. B., and T. L. Prickett. 1998. Mouth of the Colorado River, Texas, monitoring program: Monitoring completed navigation projects program. Coastal and Hydraulics Laboratory Technical Report TR CHL-98-2. Vicksburg, MS: U.S. Army Engineer Waterways Experiment Station.

Komar, P. D., and D. L. Inman. 1970. Longshore sand transport on beaches, J ournal of Geophysical Research 75(30):5,514-5,527.

Kraus, N. C. 2007. Coastal inlets of Texas, USA. Proceedings, Coastal Sediments '07, ASCE, 1,475-1,488.

Kraus, N. C., and D. J . Heilman. 1997. Packery Channel feasibility study: Inlet functional design and sand management. Technical Report TAMU-CC-CBI-96-06. Corpus Christi, TX: Texas A\&M University, 106 p. (plus appendices).

Kraus, N. C., and A. Militello. 1996. Hydraulic feasibility of proposed Southwest Corner Cut, East Matagorda Bay, Texas. Conrad Blucher Institute for Surveying and Science Technical Report TAMU-CC-CBI-96-03. Corpus Christi, TX: Texas A\&M University-Corpus Christi.

. 1999. Hydraulic study of multiple inlet system: East Matagorda Bay, Texas. J ournal of Hydraulic Research 125(3):4-232.

Kraus, N. C., C. I. Thurlow, D. J . Heilman, A. Lindquist, and M. W. Earle. 1997. Needs assessment for water level gauging along the Texas coast for the U.S. Army Corps of Engineers, Galveston District. Coastal and Hydraulics Laboratory Technical Report CHL-97-29. Vicksburg, MS: U.S. Army Engineer Waterways Experiment Station.

Kraus, N. C., L. Lin, and R. G. Barcak. 2002. Alternatives for reducing shoaling at the Mouth of the Colorado River navigation channel, Texas. Dredging 2002, CD-ROM. Proceedings, 3rd Specialty Conference on Dredging and Dredged Material Disposal, ASCE, Orlando, FL.

Lin, L., N. C. Kraus, and R. G. Barcak. 2001. Predicting hydrodynamics of a proposed multiple-inlet system, Colorado River, Texas. Proceedings, 7th International Conference on Estuarine and Coastal Modeling, ASCE, St. Petersburg, FL.

. 2003. Modeling coastal sediment transport at the Mouth of the Colorado River, Texas. Proceedings, 8th International Estuarine and Coastal Modeling Conference, ASCE, 988-1,006.

Lin, L., H. Mase, F. Yamada, and Z. Demirbilek. 2006. Wave-action balance diffraction (WABED) model, Tests of wave diffraction and reflection at inlets. Coastal Inlet Research Program Technical Note ERDC/CHL CHETN-III-73. Vicksburg, MS: U.S. Army Engineer Research and Development Center, http://chl.erdc.army.mil/chetn. 
Luettich, R. A., J. J . Westerink, and N. W. Scheffner. 1992. An advanced threedimensional circulation model for shelves, coasts and estuaries, Report 1: Theory and methodology of ADCIRC-2Ddi and ADCIRC-3DL. Dredging Research Program Technical Report DRP-92-6. Vicksburg, MS: U.S. Army Engineer Waterways Experiment Station, 137 pp.

Mase, H., K. Oki, T. S. Hedges, H. J . Li. 2005. Extended energy-balance-equation wave model for multidirectional random wave transformation. Ocean Engineering 32(8-9):961-985.

Militello, A., C. W. Reed, A. K. Zundel, and N. C. Kraus. 2004. Two-dimensional depthaveraged circulation model M2D: Version 2.0, Report 1: Documentation and user's guide. Coastal and Hydraulics Laboratory Technical Report ERDC/CHL TR-04-2. Vicksburg, MS: U.S. Army Engineer Research and Development Center.

Morton, R. A., M. J . Peiper, and J . H. McGowen. 1976. Shoreline changes on Matagorda Peninsula (Brown Cedar Cut to Pass Cavallo): An analysis of historical changes of the Texas Gulf shoreline. Geological Circular 76-6. Austin, TX: The University of Texas at Austin, Bureau of Economic Geology, 50 p.

Ono, N., A. M. Buttolph, and N. C. Kraus. 2007. Simulation of Coastal Inlet Processes by Advection-Diffusion Transport Model. Proceedings, 30th Coastal Engineering Conference, World Scientific Publishers, in press.

Parker, N. E. 1979. Weir jetties - their continuing evolution. Shore and Beach 47(4):15-19.

Ralston, O. 1987. Mouth of the Colorado River. Transcript, 47th Coastal Engineer Research Board Meeting. Corpus Christi, Texas, 19-21 May 1987.

Sargent, F., and R. Bottin. 1989. Case histories of Corps breakwaters and jetty structures. Report 9 Southwestern Division, J anuary 1989. Washington, DC: U.S. Army Corps of Engineers.

Seabergh, W. C. 1983. Weir jetty performance: Hydraulic and sedimentary considerations, hydraulic model investigation. Hydraulics Laboratory Technical Report HL-83-5. Vicksburg, MS: U.S. Army Engineer Waterways Experiment Station.

. 2002. Inner bank erosion processes and solutions at coastal inlets. Coastal and Hydraulics Laboratory Technical Note ERDC/ CHL CHETN IV-52. Vicksburg, MS: U.S. Army Engineer Research and Development Center, http://chl.erdc.army.mil/chetn.

Seabergh, W. C., and L. J . Thomas. 2002. Weir jetties at coastal inlets: Part 2, case studies. Coastal and Hydraulics Laboratory Technical Note ERDC/ CHL CHETNIV-54. Vicksburg, MS: U.S. Army Engineer Research and Development Center, http://chl.erdc.army.mil/chetn.

Shore Protection Manual. 1984. 4th ed., 2 Vol, U.S. Army Engineer Waterways Experiment Station, U.S. Government Printing Office. Washington, DC.

Smith, J . M., A. R. Sherlock, and D. T. Resio. 2001. STWAVE: Steady-state spectral wave model user's manual for STWAVE, Version 3.0. Coastal and Hydraulics Laboratory Special Report ERDC/CHL SR-01-1. Vicksburg, MS: U.S. Army Engineer Research and Development Center. 
Tracy, B. A. 2004. Wave Information Studies: Hindcast wave data for U.S. coasts. Vicksburg, MS: U.S. Army Engineer Research and Development Center, http://frf.usace.army.mil/cgi-bin/wis/atl/atl_main.html.

Turner, Collie \& Braden, Inc., and DMJ M-Harris. 2002. Colorado River and Tributaries, Texas, Mouth of the Colorado River Navigation Channel in Matagorda, Texas. Sediment training structure final design report. Prepared by the U.S. Army Corps of Engineers, Contract No. DAC64-02-D-0002, Task Order No. 6.

U.S. Army Corps of Engineers. 1977. Mouth of Colorado River, Texas, Phase I: General design memorandum (Navigation Features). Galveston, TX: U.S. Army Engineer District, Galveston.

. 1981. Mouth of Colorado River, Texas, Phase I: General design memorandum and environmental impact statement (Diversion Features). Galveston, TX: U.S. Army Engineer District, Galveston.

. 1992. Inlets along the Texas Gulf coast, Section 22 Report, Planning Assistance to the States Program. Galveston, TX: U.S. Army Engineer District, Galveston.

. 2002. Project manual for storm sediment training structure: Colorado River and tributaries, Texas Mouth of the Colorado River Navigation Channel in Matagorda County, Texas. Galveston, TX: U.S. Army Engineer District, Galveston.

. 2003. Project manual for storm damage reduction and environmental restoration project: Corpus Christi, Texas, North Padre Island. Galveston, TX: U.S. Army Engineer District, Galveston.

Wadsworth, A. H., Jr. 1941. The lower Colorado River, Texas. University of Texas, unpublished M.S. thesis. Austin, TX: The University of Texas.

. 1966. Historical deltation of the Colorado River, Texas. In: Deltas in the Geological framework, M. L. Shirley, and J . A. Rogedale, eds. Houston, TX: Houston Geological Society, 99-105.

Weggel, J . R. 1981. Weir sand bypassing system. Special Report No. 8. Fort Belvoir, VA: U.S. Army Coastal Engineering Research Center.

Williams, D. D., N. C. Kraus, and C. M. Anderson. 2007. Morphologic response to a new inlet, Packery Channel, Corpus Christi, Texas. Proceedings, Coastal Sediments '07, ASCE, 1529-1542. 


\section{Appendix A: Calibration of Regional Circulation Model}

Regional tidal hydrodynamics for this study were calculated with the ADvanced CIRCulation (ADCIRC) model (Luettich et al. 1992). The regional 2-D model (Brown et al. 2003) was run to simulate a multipleinlet system for Matagorda Bay and East Matagorda Bay, MCR, and GIWW. The model calculates water surface elevation and two horizontal components of the depth-averaged current at nodes from an unstructured finite-element grid.

\section{Model verification}

The regional model was confirmed to run a 40-day simulation from 1J anuary to 9 February 2002, containing two full cycles of spring and neap tides. The simulation is for the post-dredging condition because maintenance dredging was conducted at the MCR, including the lower section of the CRNC and deposition basin, in November 2001. This time period was selected because both water level and current data were available from several ERDC gauges placed along the CRNC and GIWW in the near field. Water level data were also available for gauges located at Port Lavaca and Port O'Connor in the far field. Figure A1 shows the location of gauges installed at the CRNC and GIWW in the near field. Table A1 presents the coordinates of gauge locations.

The regional model was run using 1.5-sec time step and default control parameters. The input water level data along the ocean boundary and surface wind information were updated hourly in the model, and the river discharge boundary condition was updated at 24-hr intervals. Figure A2 shows the ocean boundary water level data, surface winds, and river discharge information as input to the simulation. 


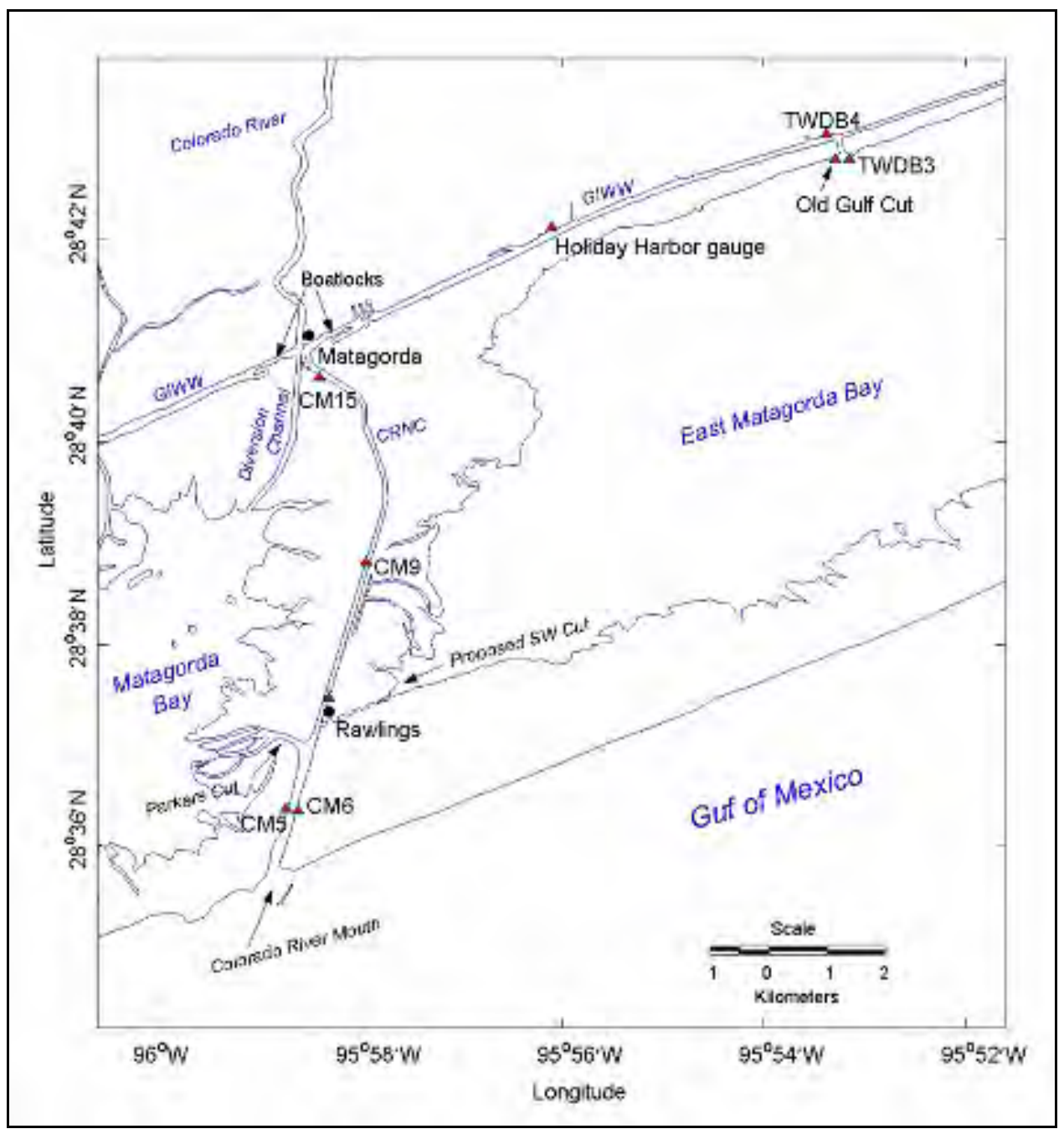

Figure A1. Location of water level gauges and current meters.

Table A1. Location of gauges.

\begin{tabular}{|l|l|l|}
\hline Gauge ID & Location & Coordinates \\
\hline Argonaut EE65 & Channel Marker 5 & $28^{\circ} 36^{\prime} 32^{\prime \prime} \mathrm{N}, 95^{\circ} 58^{\prime} 39^{\prime \prime} \mathrm{W}$ \\
\hline ADP & Channel Marker 6 & $28^{\circ} 36^{\prime} 27^{\prime \prime} \mathrm{N}, 95^{\circ} 58^{\prime} 37^{\prime \prime} \mathrm{W}$ \\
\hline Argonaut EE54 & Channel Marker 9 & $28^{\circ} 39^{\prime} 08^{\prime \prime} \mathrm{N}, 95^{\circ} 57^{\prime} 50^{\prime \prime} \mathrm{W}$ \\
\hline Argonaut EE50 & Channel Marker 15 & $28^{\circ} 40^{\prime} 44^{\prime \prime} \mathrm{N}, 95^{\circ} 58^{\prime} 26^{\prime \prime} \mathrm{W}$ \\
\hline Argonaut EE51 & GIWW, Holiday Harbor & $28^{\circ} 43^{\prime} 00^{\prime \prime} \mathrm{N}, 95^{\circ} 53^{\prime} 24^{\prime \prime} \mathrm{W}$ \\
\hline NOAA 87733041 & Rawlings & $28^{\circ} 37^{\prime} 24^{\prime \prime} \mathrm{N}, 95^{\circ} 58^{\prime} 12^{\prime \prime} \mathrm{W}$ \\
\hline NOAA 87731181 & GIWW, Old Gulf Cut & $28^{\circ} 42^{\prime} 48^{\prime \prime} \mathrm{N}, 95^{\circ} 53^{\prime} 18^{\prime \prime} \mathrm{W}$ \\
\hline CBI 117 TWDB 4 & Old Gulf Cut & $28^{\circ} 43^{\prime} 00^{\prime \prime} \mathrm{N}, 95^{\circ} 53^{\prime} 24^{\prime \prime} \mathrm{W}$ \\
\hline NOAA 87732591 & Port Lavaca & $28^{\circ} 38^{\prime} 24^{\prime \prime} \mathrm{N}, 96^{\circ} 36^{\prime} 36^{\prime \prime} \mathrm{W}$ \\
\hline NOAA 87737011 & Port O'Connor & $28^{\circ} 26^{\prime} 48^{\prime \prime} \mathrm{N}, 96^{\circ} 23^{\prime} 48^{\prime \prime} \mathrm{W}$ \\
\hline
\end{tabular}




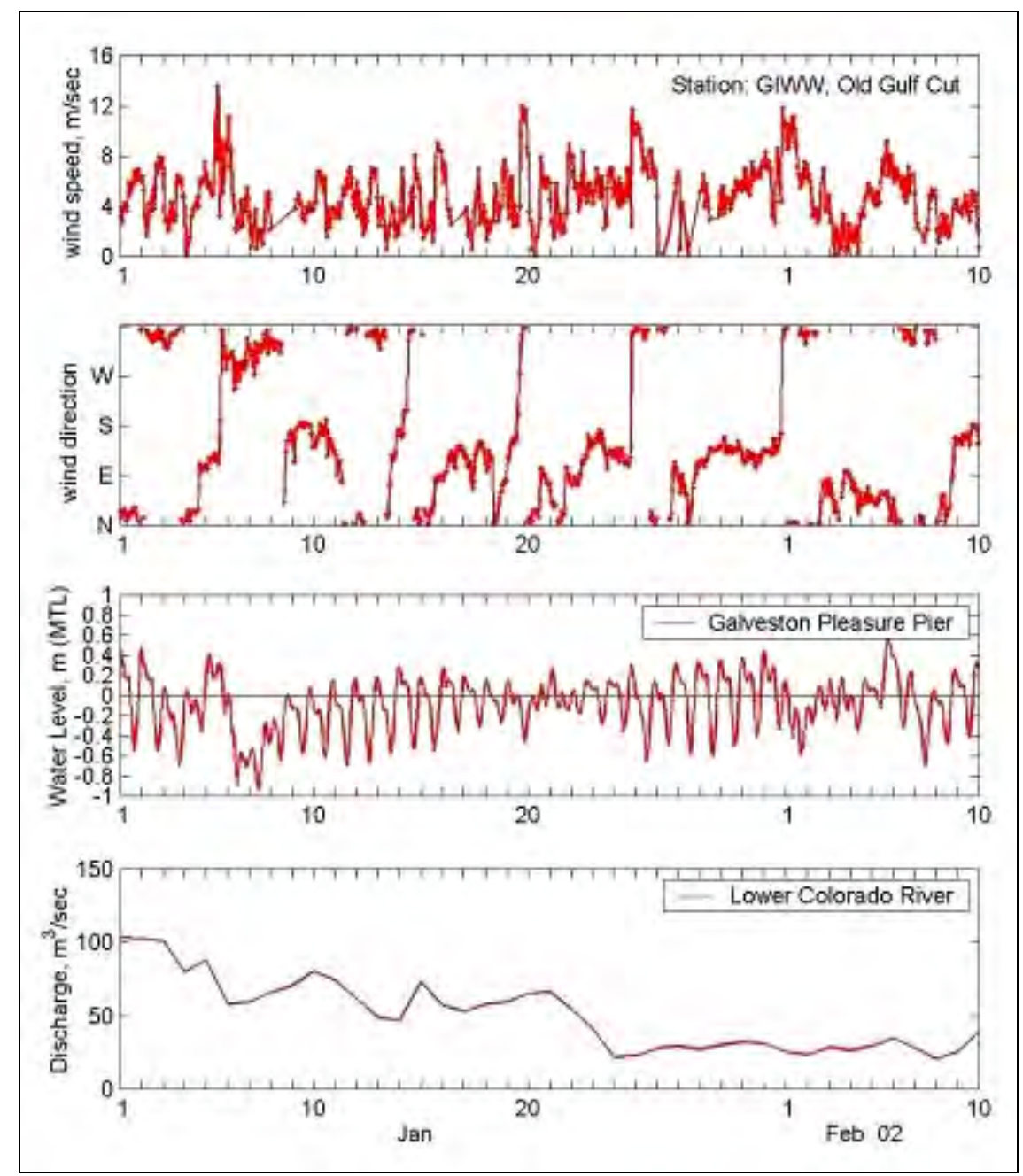

Figure A2. Surface winds, water levels, and river discharges for model input boundary conditions.

Calculation results were saved in 1-hr intervals for comparison to the measured water level and current velocity. Figure A3 shows measured and calculated water levels at Port Lavaca, Port O'Connor, Rawlings, and GIWW Old Gulf Cut NOAA gauge locations. Figure A4 compares measured and calculated water levels at Channel Markers 5, 9, and 15 in the CRNC and at Holiday Harbor in the GIWW. The calculated water levels agree well with the measurements. Table A2 presents the statistics comparing the measured and calculated water levels. 


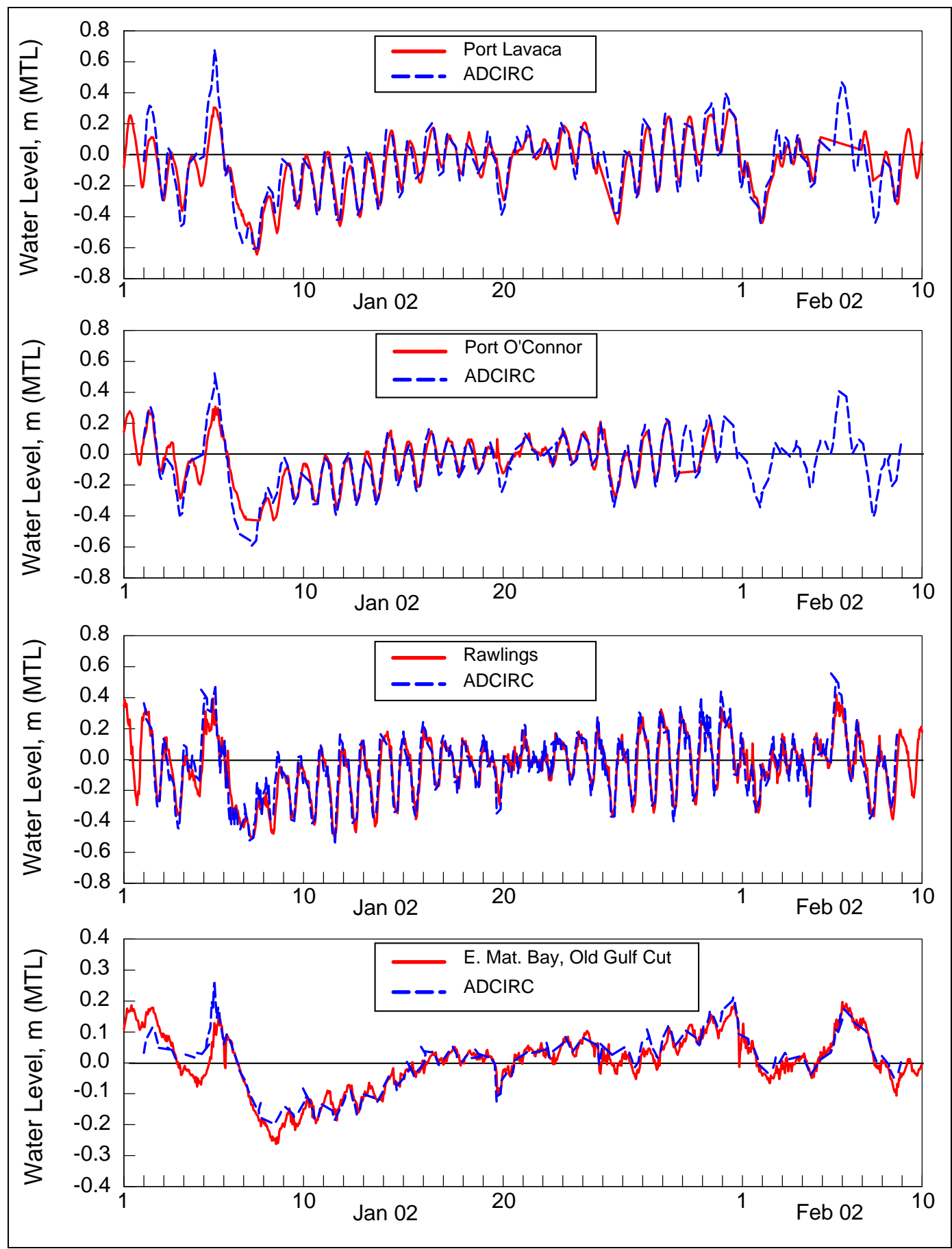

Figure A3. Measured and calculated water levels at Port Lavaca, Port O'Connor, Rawlings, and at East Matagorda Bay, Old Gulf Cut. 


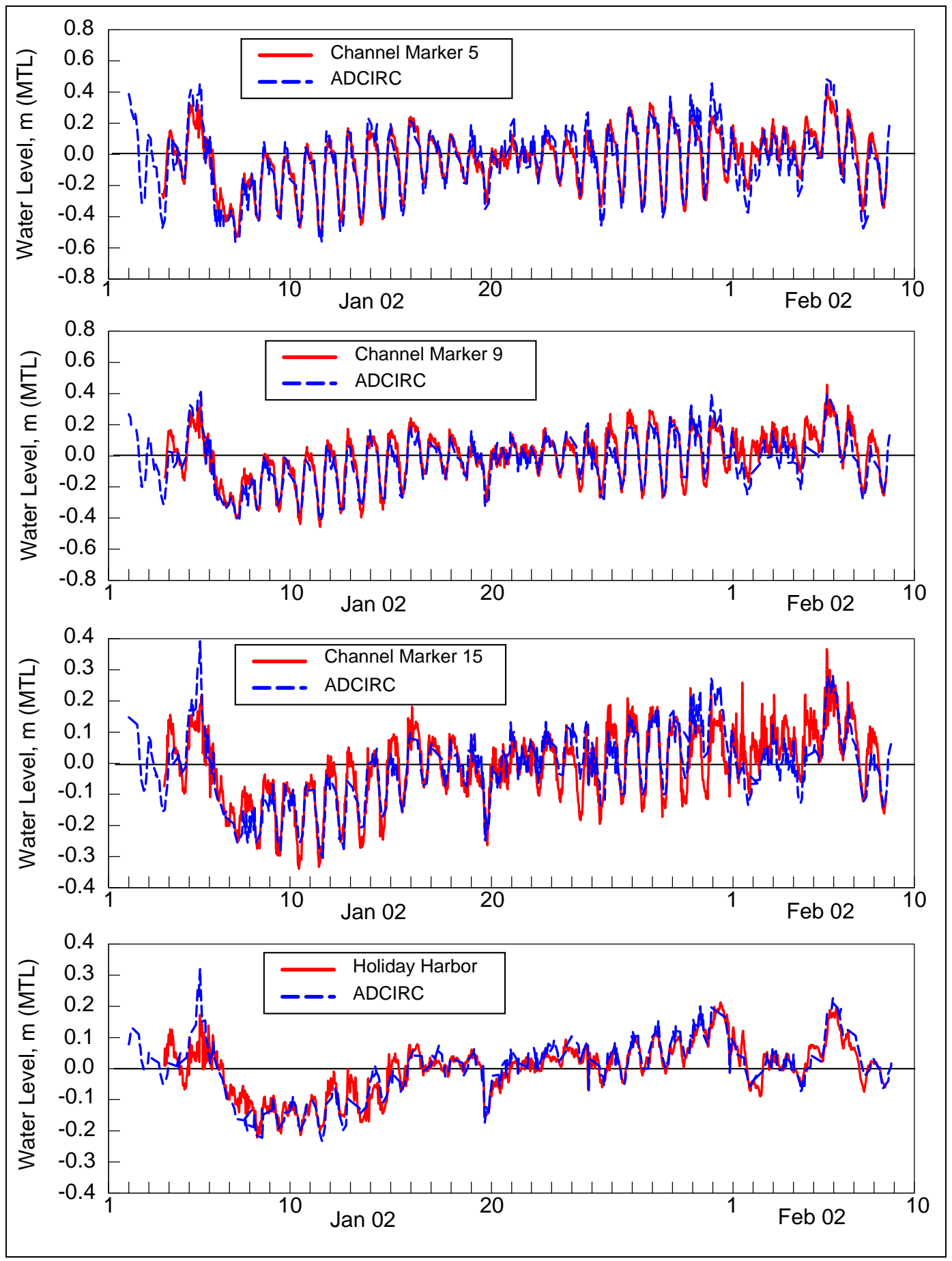

Figure A4. Measured and calculated water levels at Channel Markers 5, 9, and 15, and at Holiday Harbor, GIWW. 
Table A2. Water surface elevation bias, RMS error, and percent error, 2 January to 8 February 2002.

\begin{tabular}{|c|c|c|c|c|}
\hline Location & Sample Size & Bias (m) & RMS Error (m) & Percent Error \\
\hline Port Lavaca & 833 & 0.014 & 0.090 & 32 \\
\hline Port O'Connor & 638 & -0.007 & 0.066 & 27 \\
\hline Rawlings & 913 & 0.009 & 0.081 & 20 \\
\hline $\begin{array}{l}\text { E. Mat. Bay, } \\
\text { Old Gulf Cut }\end{array}$ & 913 & 0.009 & 0.031 & 10 \\
\hline CM5 & 865 & -0.007 & 0.084 & 21 \\
\hline CM9 & 861 & -0.026 & 0.077 & 19 \\
\hline CM15 & 862 & -0.006 & 0.066 & 16 \\
\hline Holiday Harbor & 861 & 0.002 & 0.039 & 13 \\
\hline $\begin{array}{l}\text { Remarks: } \\
\text { Percent error }= \\
\text { Tidal range is } 0 . \\
\text { and } 0.3 \mathrm{~m} \text { in th }\end{array}$ & $\begin{array}{l}\text { MS Error/Tida } \\
8 \mathrm{~m} \text { at Port La }\end{array}$ & $\begin{array}{l}\text { Range. } \\
\text { aca, } 0.2 \\
\text { ion. }\end{array}$ & rt O'Connor, C & n at Rawlings, \\
\hline
\end{tabular}

Figures A5 and A6 compare measurements and calculations of current velocity at Channel Markers 5, 6, 9, and 15, Holiday Harbor, and TWDB4. The calculated current velocity is slightly weaker than the measured flood and ebb current peaks. The phase is well represented. The calculated current is a depth-average, whereas the measurements were made approximately 3 to $5 \mathrm{ft}$ below the water surface where the current velocity is typically stronger than the depth-average velocity. The current meters were mounted in this way so as to be easily deployed and recovered by boat. Table A3 presents the statistics comparing the measured and calculated current velocity. 


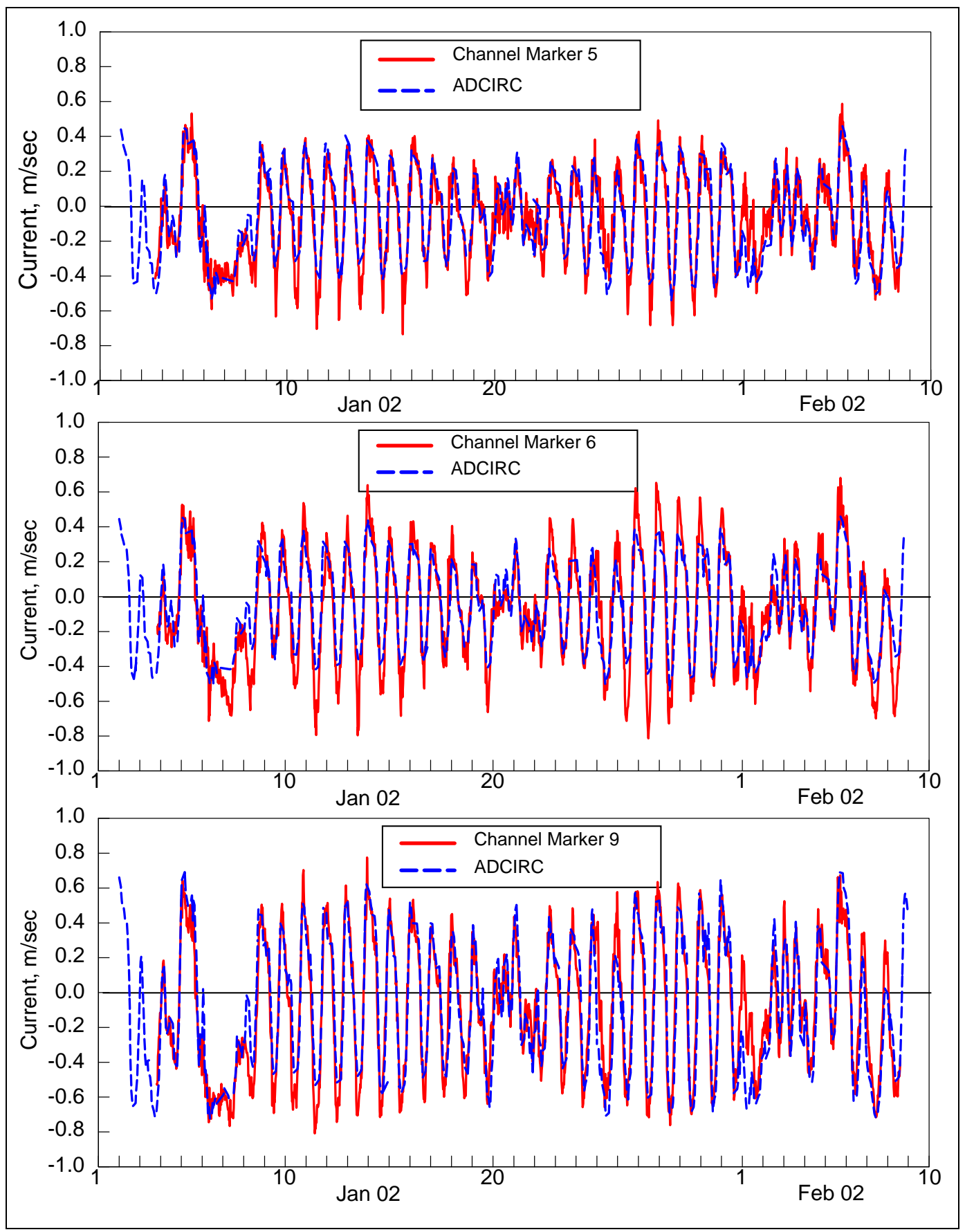

Figure A5. Measured and calculated currents at Channel Markers 5, 6, and 9. 


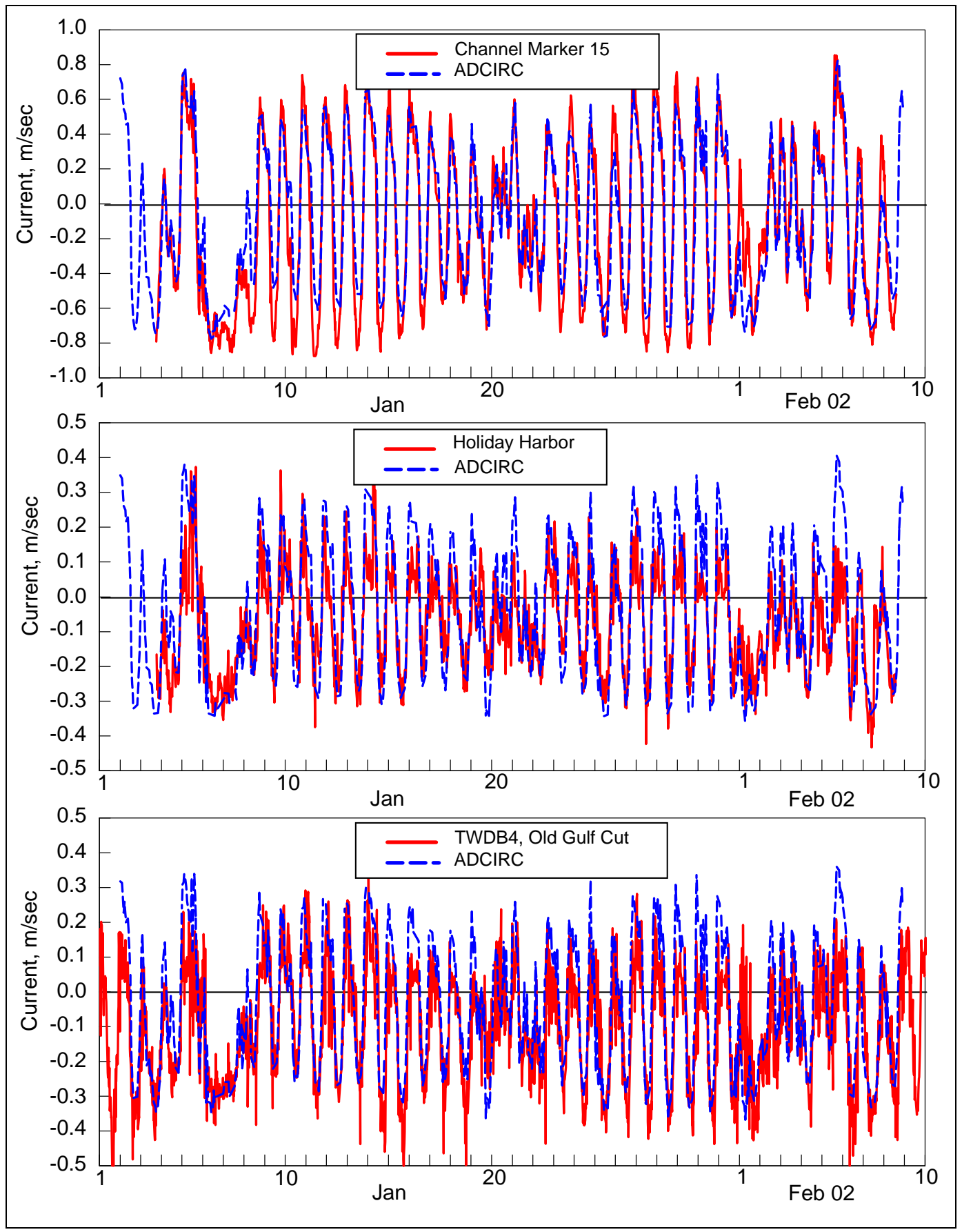

Figure A6. Measured and calculated currents at Channel Marker 15, Holiday Harbor, and TWDB4. 
Table A3. Velocity bias, RMS errors, and averaged maximum flood and ebb currents, 2 January to 8 February 2002.

\begin{tabular}{|l|l|l|l|l|l|}
\hline Location & $\begin{array}{l}\text { Sample } \\
\text { Size }\end{array}$ & $\begin{array}{l}\text { Bias } \\
(\mathrm{m} / \mathrm{sec})\end{array}$ & $\begin{array}{l}\text { RMS } \\
\text { Errors } \\
(\mathrm{m} / \mathrm{sec})\end{array}$ & $\begin{array}{l}\text { Bias, Averaged } \\
\text { Maximum Flood } \\
\text { Current }(\mathrm{m} / \mathrm{sec})\end{array}$ & $\begin{array}{l}\text { Bias, Averaged } \\
\text { Maximum Ebb } \\
\text { Current }(\mathrm{m} / \mathrm{sec})\end{array}$ \\
\hline CM 6 & 859 & 0.017 & 0.126 & -0.11 & 0.16 \\
\hline CM5 & 864 & 0.006 & 0.109 & -0.05 & 0.10 \\
\hline CM9 & 860 & 0.001 & 0.142 & -0.05 & 0.05 \\
\hline CM15 & 860 & 0.024 & 0.184 & -0.09 & 0.11 \\
\hline $\begin{array}{l}\text { Holiday } \\
\text { Harbor }\end{array}$ & 860 & 0.033 & 0.124 & 0.05 & 0.01 \\
\hline TWDB4 & 775 & 0.055 & 0.127 & 0.08 & 0.07 \\
\hline
\end{tabular}

The calculated discharge was verified by the flow rate estimated from vertical and horizontal velocity profile data collected at the cross section of Channel Markers 5 and 6. The vertical velocity profile data were collected across the channel for every half-hour interval in one diurnal tide cycle from 1 p.m. on $10 \mathrm{~J}$ anuary to 1 p.m. on 11J anuary 2001. The water surface horizontal velocities were measured for 40 days from $1 \mathrm{~J}$ anuary to 9 February 2001. The flow rate was first estimated from the vertical velocity profile data collected in one diurnal tide cycle. The flow rate was then transformed to the 40-day simulation period by a linear regression of the flow rate and water surface velocities. The regression was conducted separately for flood and ebb tide.

Figure A7 shows the flow rate estimated from the vertical velocity profile data and the discharge data calibrated after the regression. Figure A8 shows the calculated discharge versus the estimated and calibrated discharges. The calculated discharge overall agrees with the calibrated discharge for flood tide, but tends to overestimate the discharge for the ebb tide. Table A4 presents the statistics comparing calculated and calibrated discharges. 


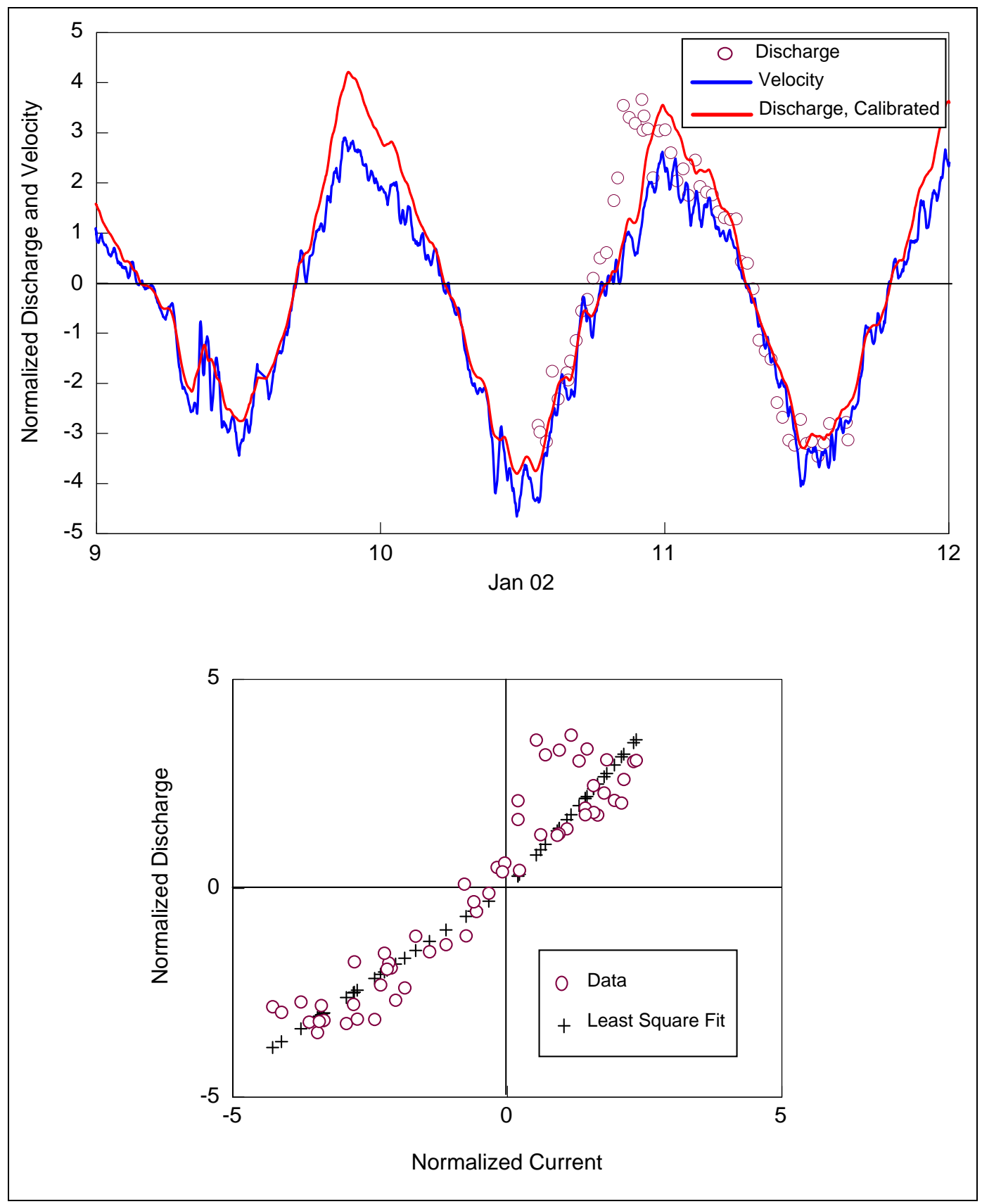

Figure A7. Linear regression of flow rates and velocity data. 


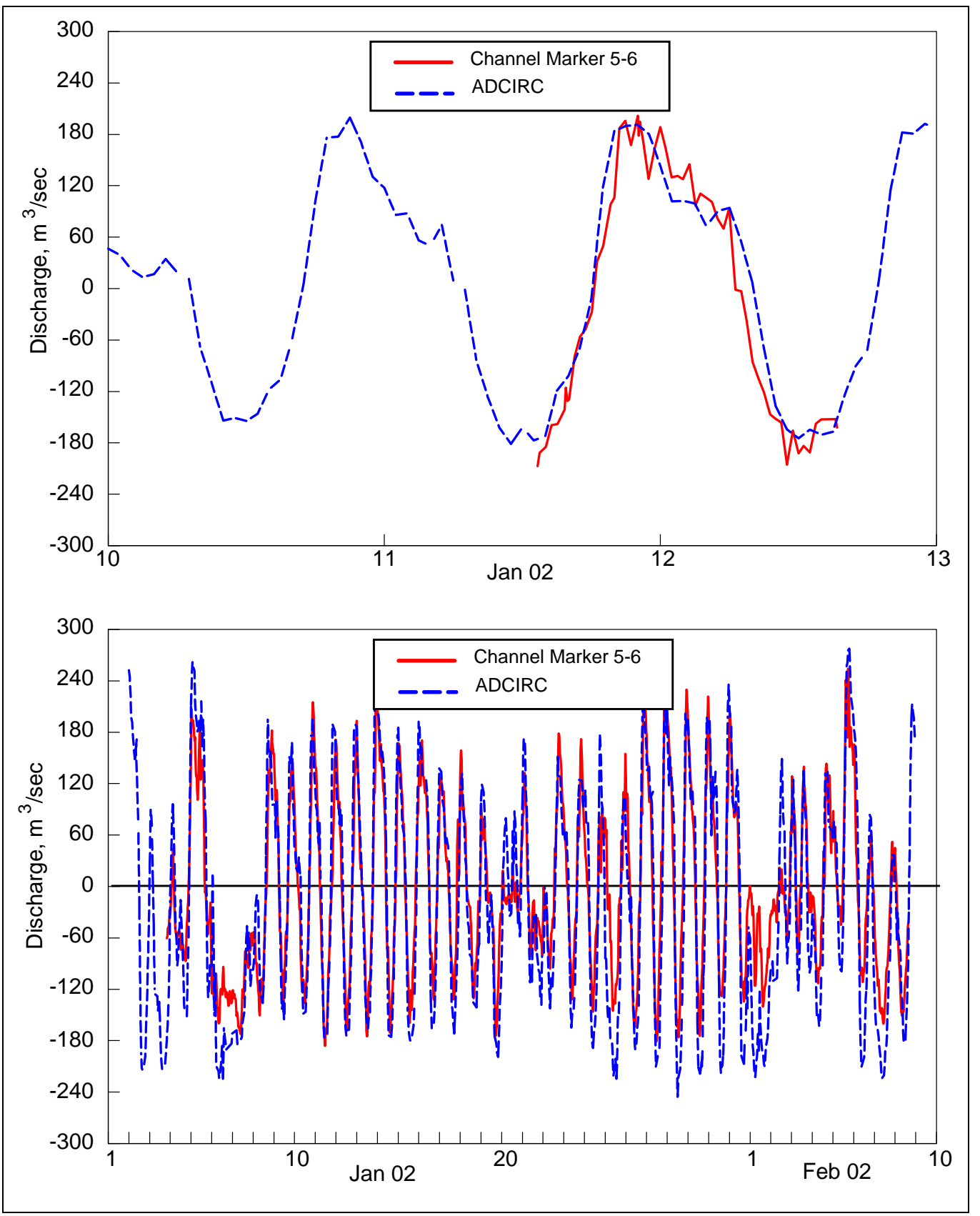

Figure A8. Calculated discharge and calibrated flow rate.

Table A4. Flow rate bias and averaged maximum flood and ebb discharges,

2 January to 8 February 2002.

\begin{tabular}{|l|l|l|l|l|l|}
\hline & $\begin{array}{l}\text { Sample } \\
\text { Size }\end{array}$ & $\begin{array}{l}\text { Bias, } \\
\text { Flood } \\
\text { Discharge } \\
\left(\mathrm{m}^{3} / \mathrm{sec}\right)\end{array}$ & $\begin{array}{l}\text { Bias, Ebb } \\
\text { Discharge } \\
\left(\mathrm{m}^{3} / \mathrm{sec}\right)\end{array}$ & $\begin{array}{l}\text { Bias, Averaged } \\
\text { Maximum Flood } \\
\text { Discharge } \\
\left(\mathrm{m}^{3} / \mathrm{sec}\right)\end{array}$ & $\begin{array}{l}\text { Bias, Averaged } \\
\text { Maximum Ebb } \\
\text { Discharge } \\
\left(\mathrm{m}^{3} / \mathrm{sec}\right)\end{array}$ \\
\hline $\begin{array}{l}\text { Channel } \\
\text { Markers } \\
5 \text { and 6 }\end{array}$ & 886 & 12.2 & -44.2 & 11.6 & -42.2 \\
\hline
\end{tabular}




\section{Appendix B: Summary of Figures for Calculated Current Velocities at sta 1, sta 2, and sta 3}

Figures B1 to B3 compare current velocities calculated from the regional circulation model at sta 1 to sta 3 for the existing MCR condition and for the new east jetty with and without opening SW Corner Cut and Parkers Cut.
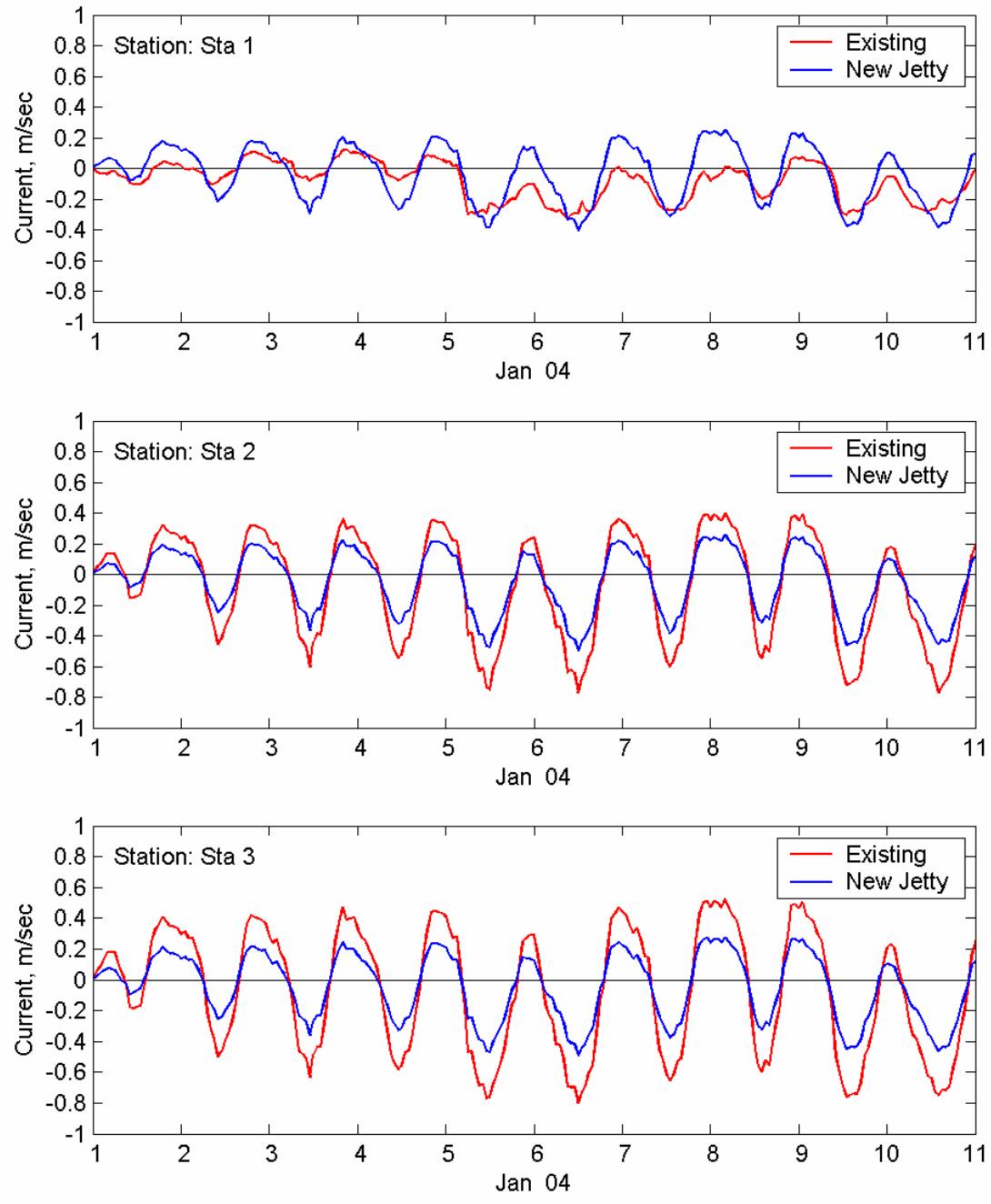

Figure B1. Calculated velocity for existing condition and new east jetty. 

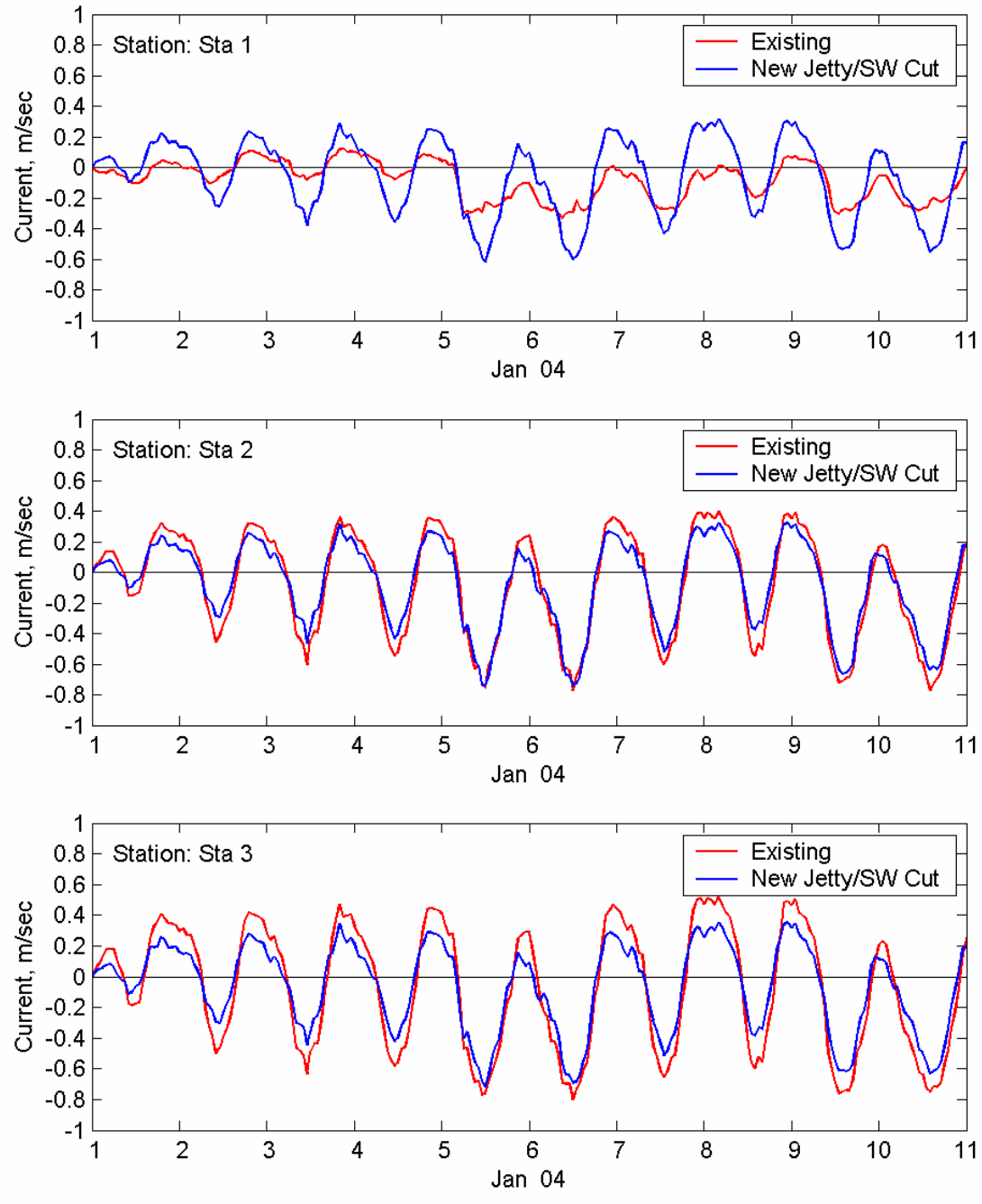

Figure B2. Calculated velocity for existing condition and opening the SW Corner Cut with new east jetty. 

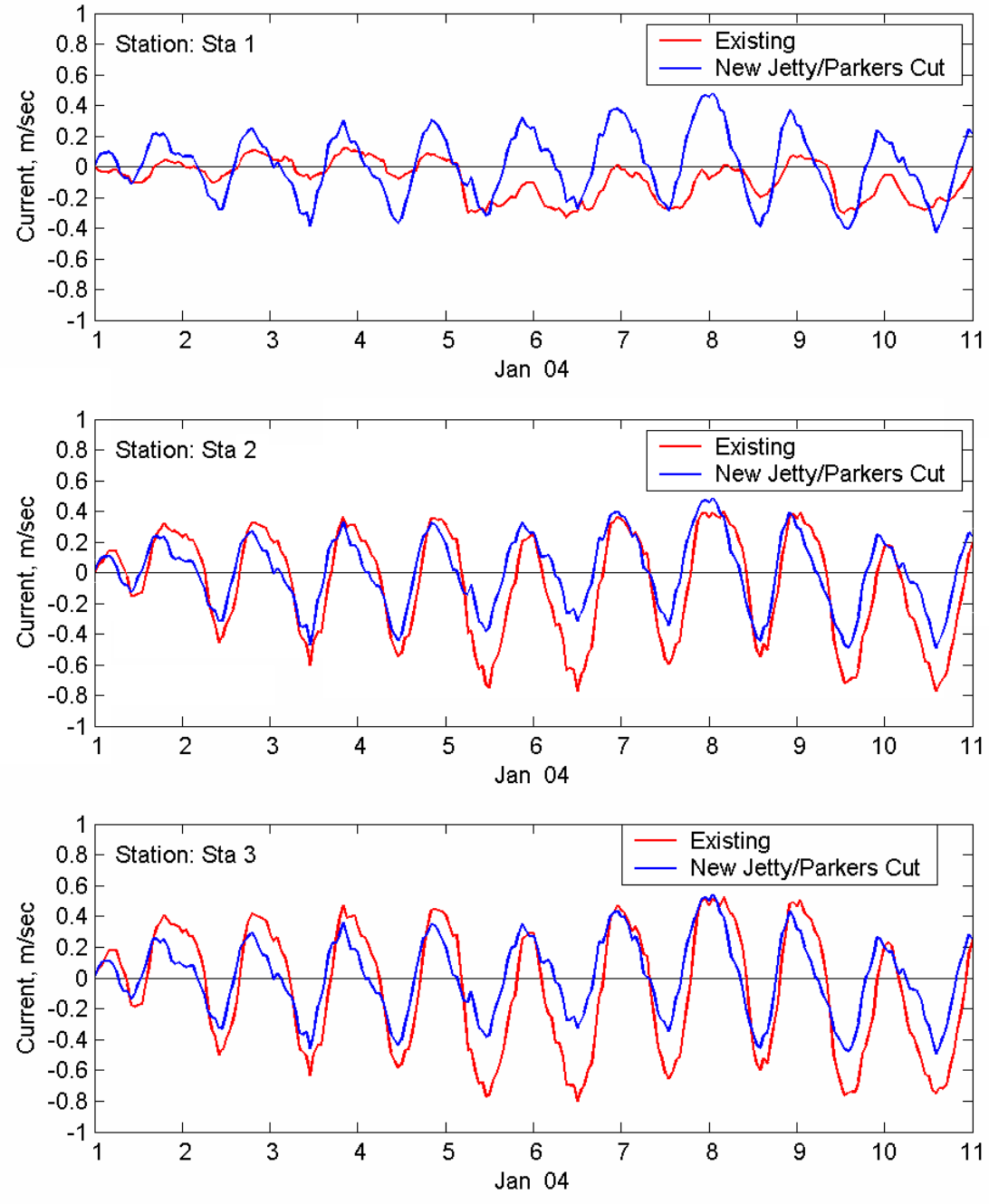

Figure B3. Calculated velocity for existing condition and opening Parkers Cut. 


\section{Appendix C: Aerial Photographs, Mouth of Colorado River}

This appendix documents available aerial photographs of the Mouth of the Colorado River, TX, and vicinity.

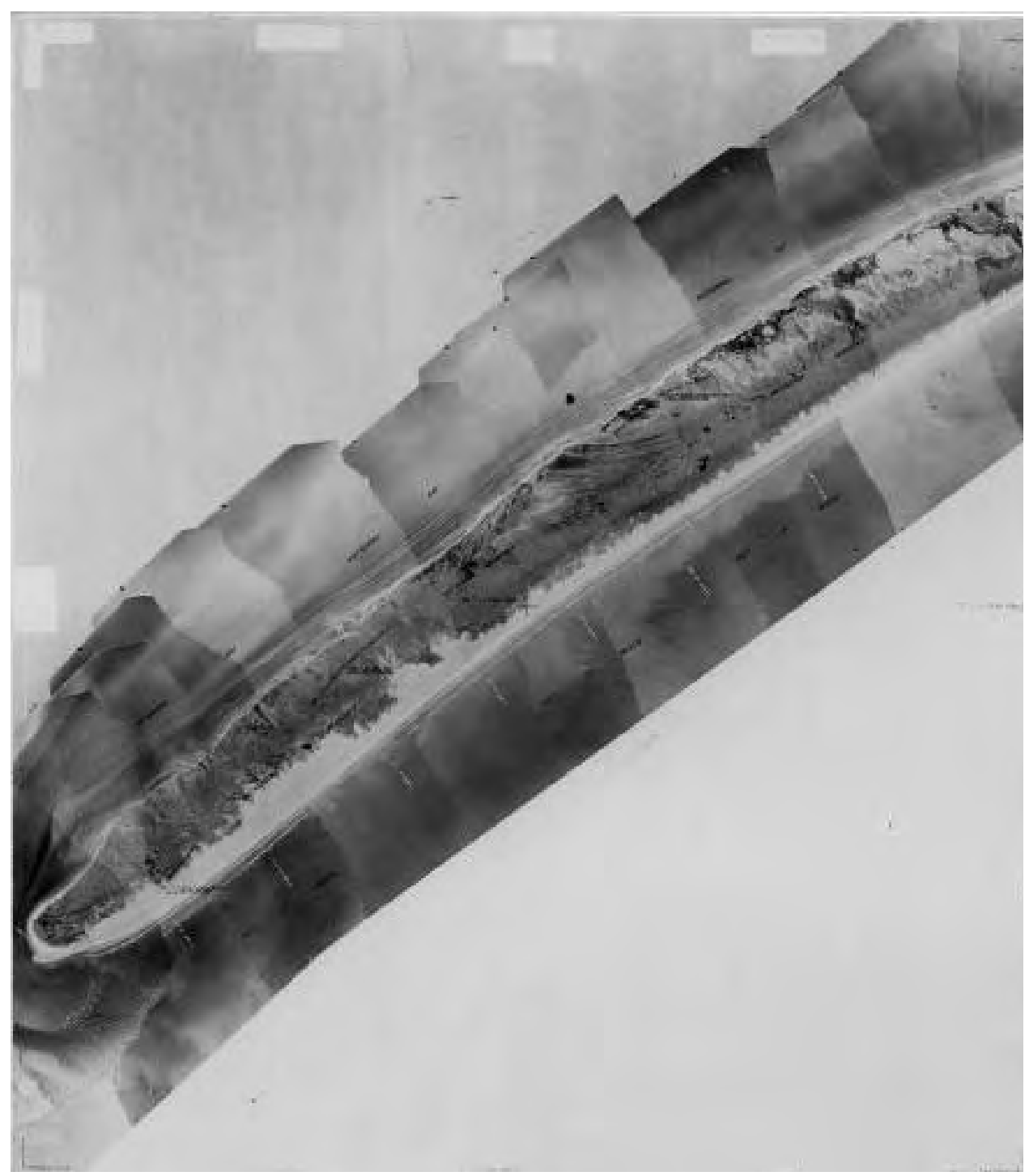

Figure C1. File 30-Matagorda-A.jpg, Matagorda Bay, 1930 s. 


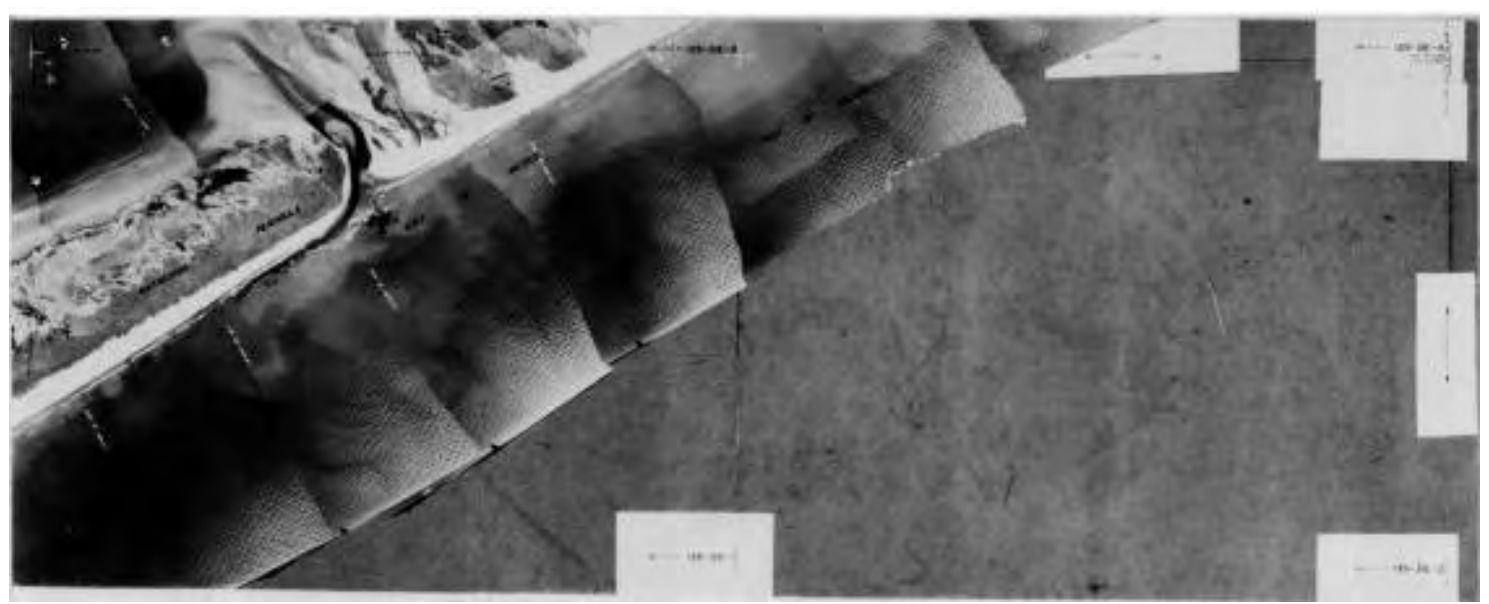

Figure C2. File 30-Matagorda-B.jpg, Matagorda Bay, Mouth of Colorado River 1930s.

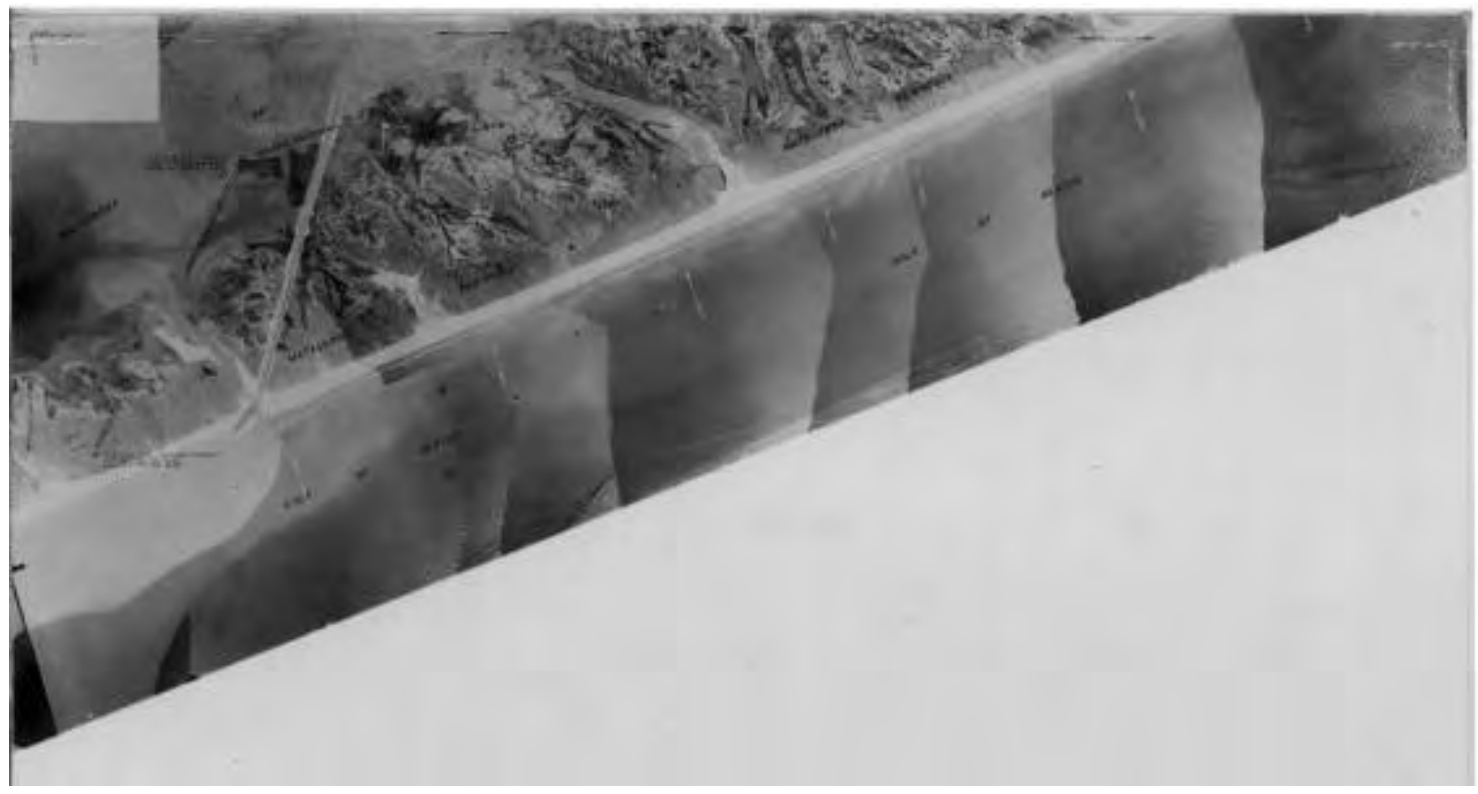

Figure C3. File 30-Matagorda-C.jpg, Matagorda Bay, 1930s. 


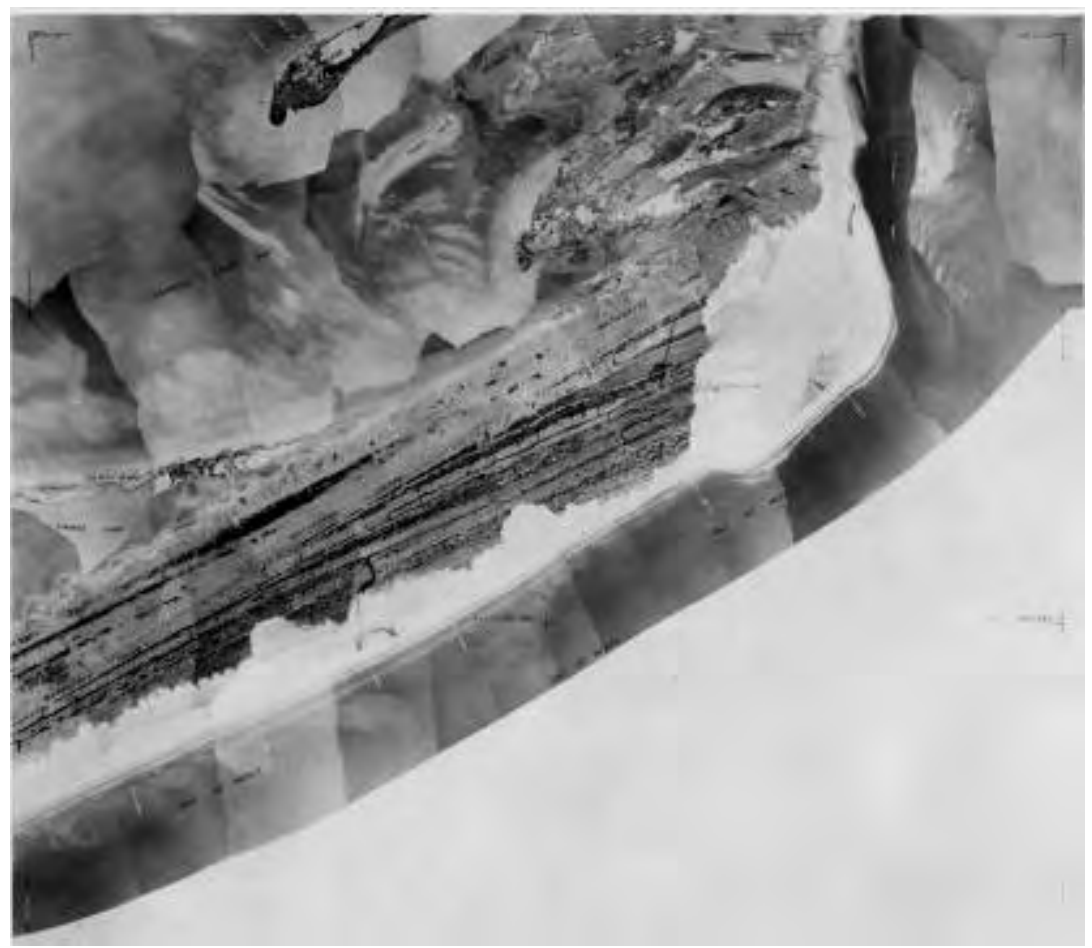

Figure C4. File 30-Matagorda-E.jpg, Mouth of Colorado River, 1930 s.

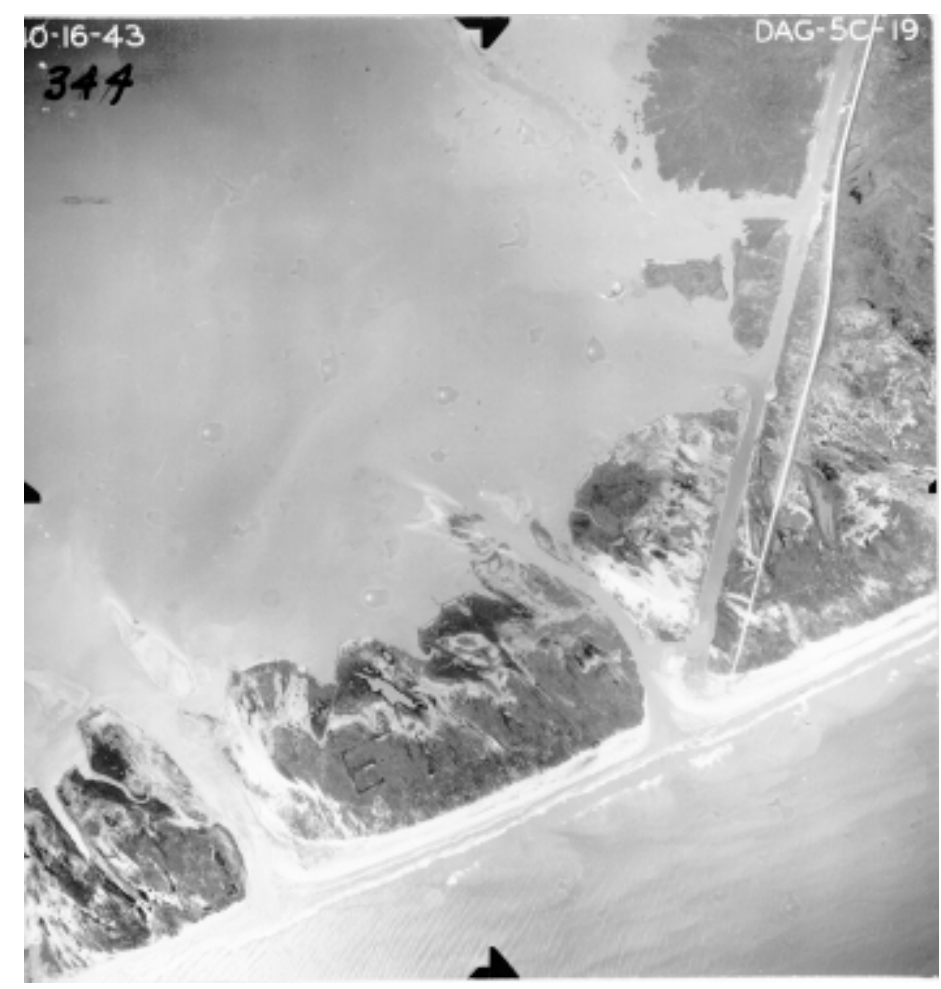

Figure C5. File 43-10-16-MOC-A.tif, Mouth of Colorado River, East Matagorda Bay, 16 October 1943. 


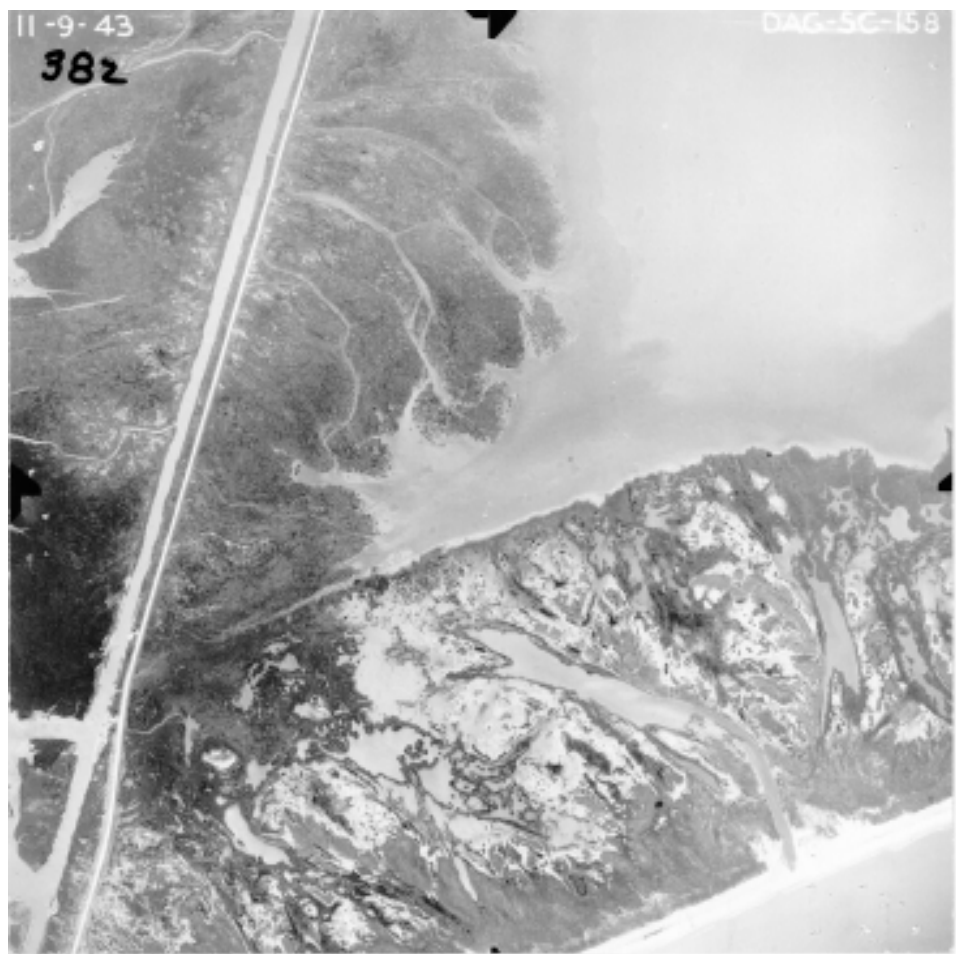

Figure C6. File 43-10-16-MOC-B.tif, Mouth of Colorado River, 16 October 1943.

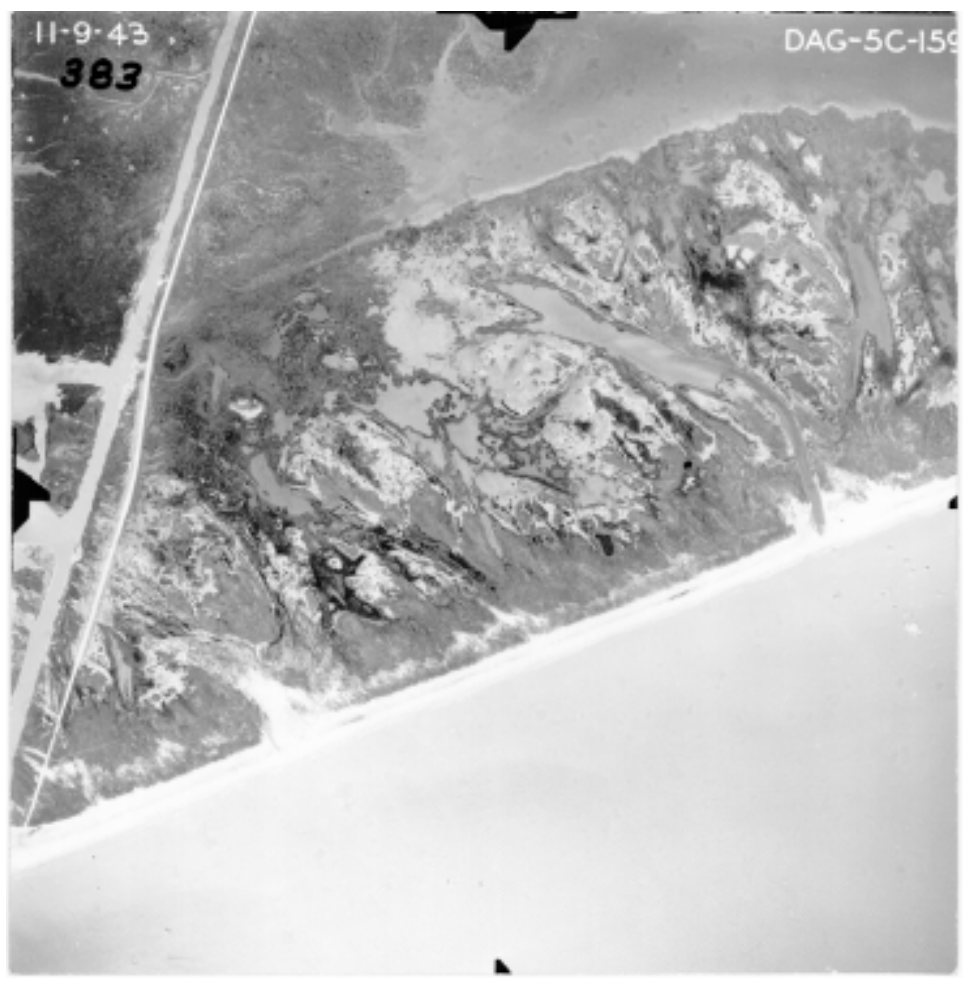

Figure C7. File 43-10-16-MOC-C.tif, Mouth of Colorado River, East Matagorda Bay, 16 October 1943. 


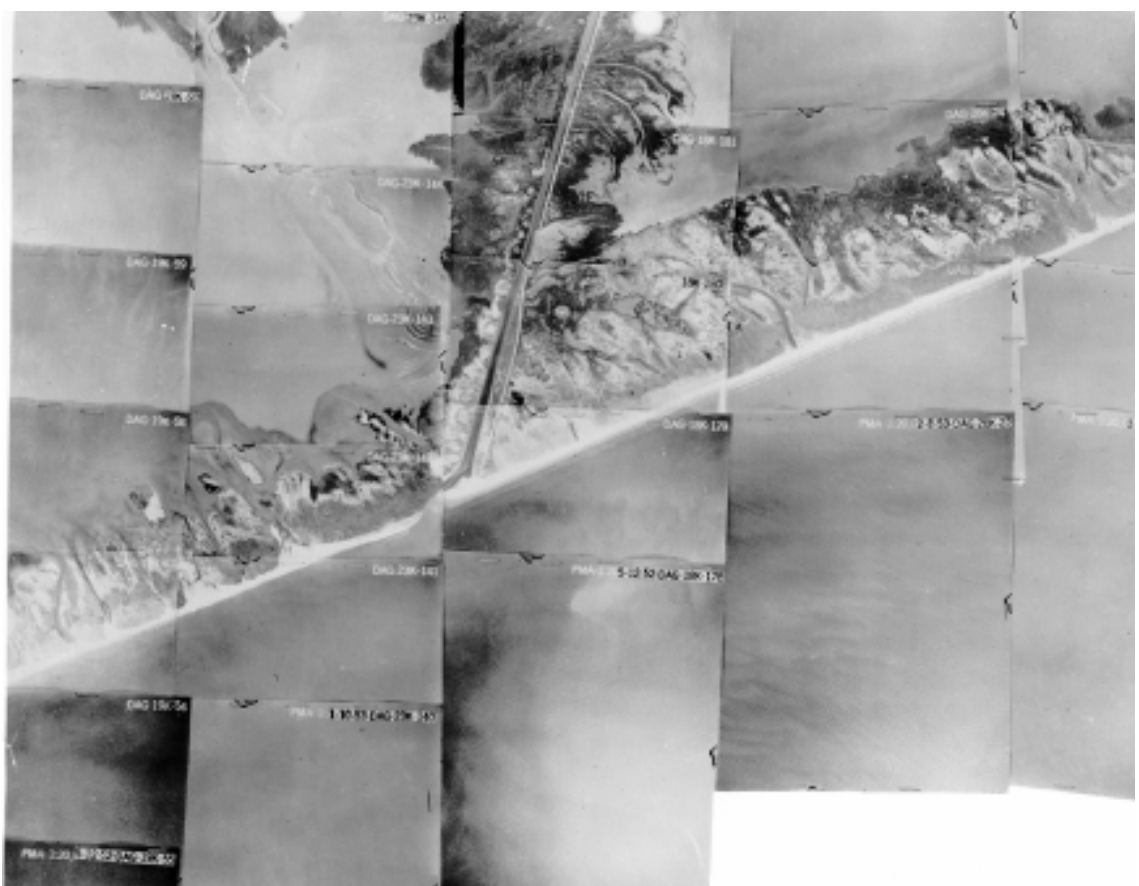

Figure C8. File 53-2-8-MOC.tif, Mouth of Colorado River, 8 February 1953.
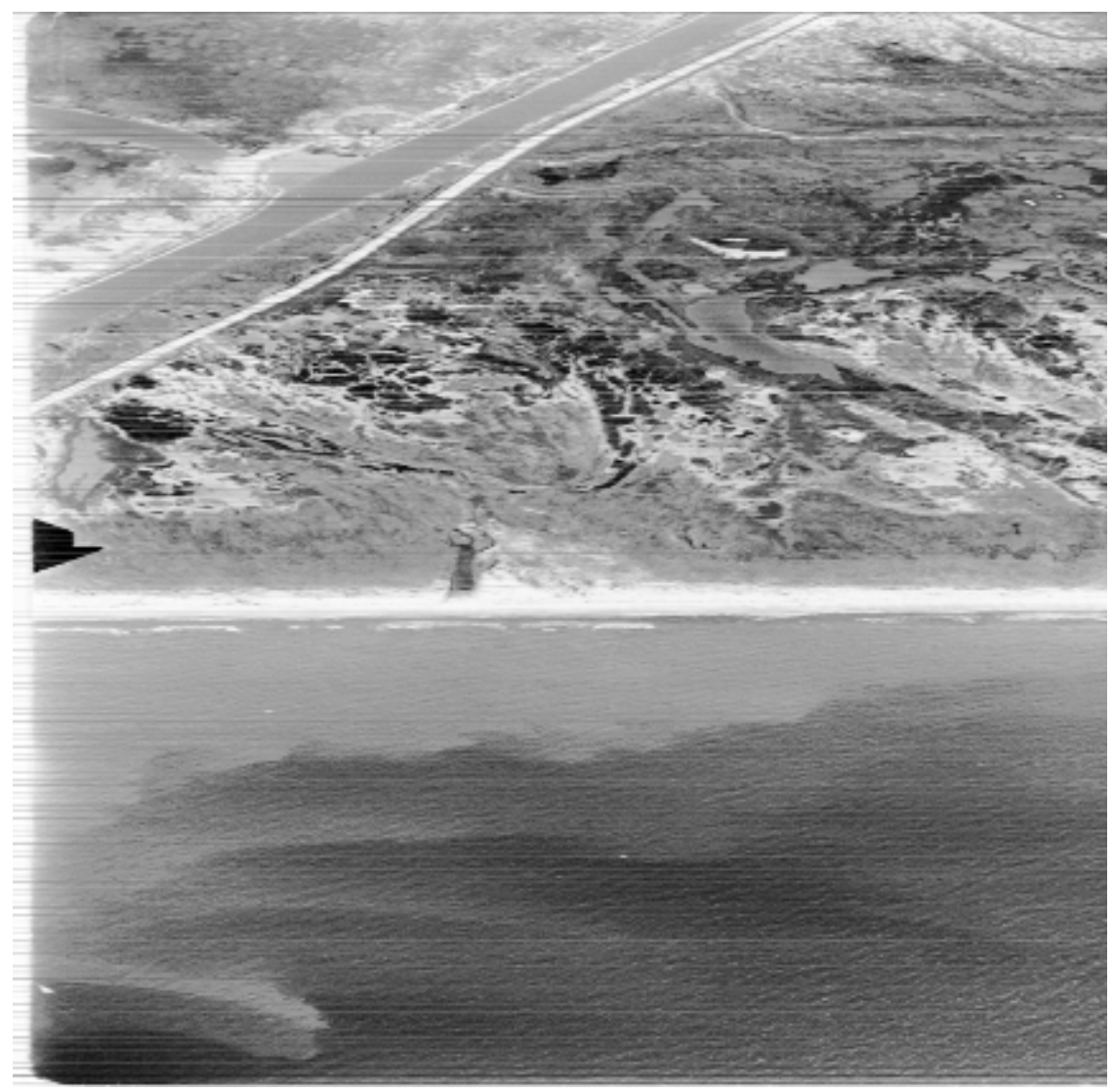

Figure C9. File 54-1-1-MOC.tif, Mouth of Colorado River, 1 January 1954. 


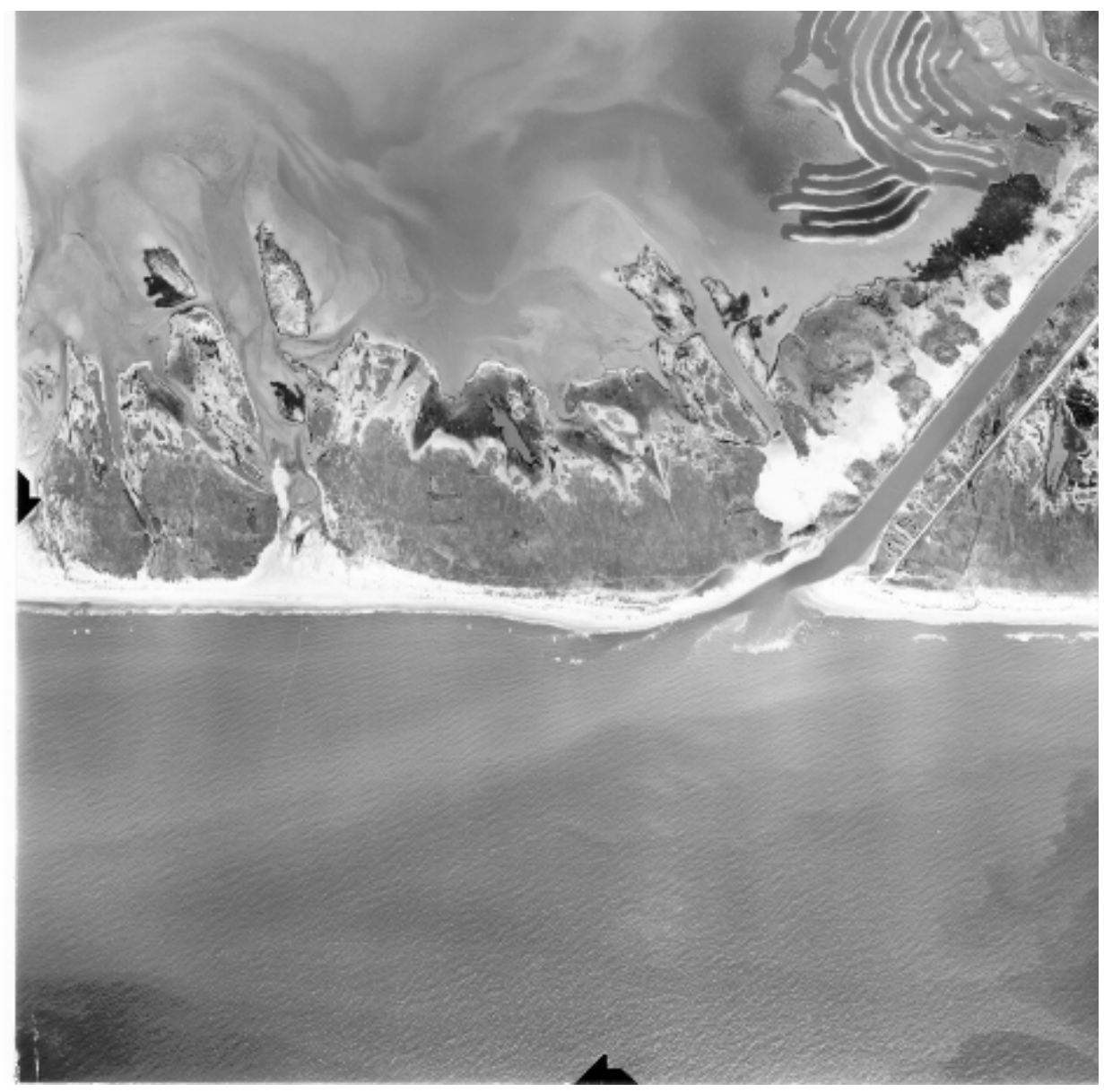

Figure C10. File 54_CR.tif, Mouth of Colorado River, 1954s.

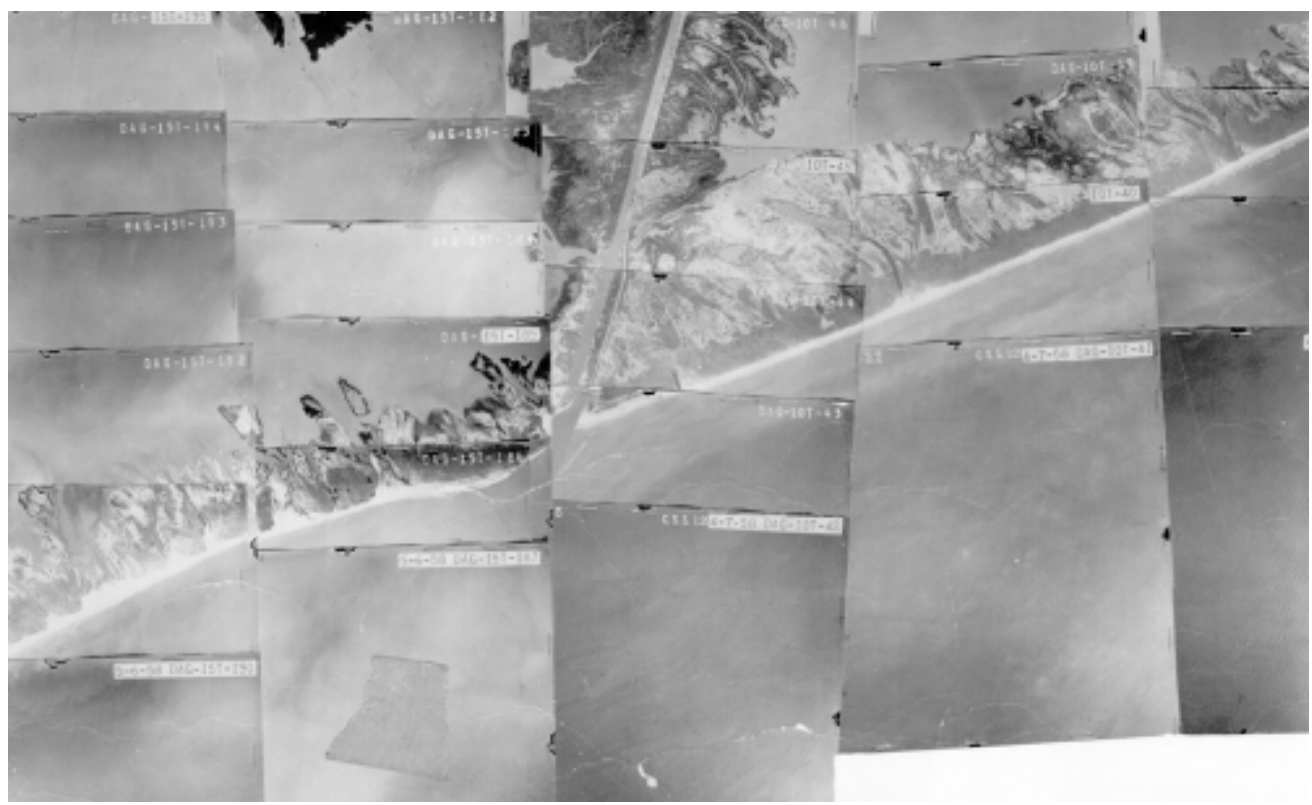

Figure C11. File 58-12-11-MOC.tif, Mouth of Colorado River, 12 December 1958. 


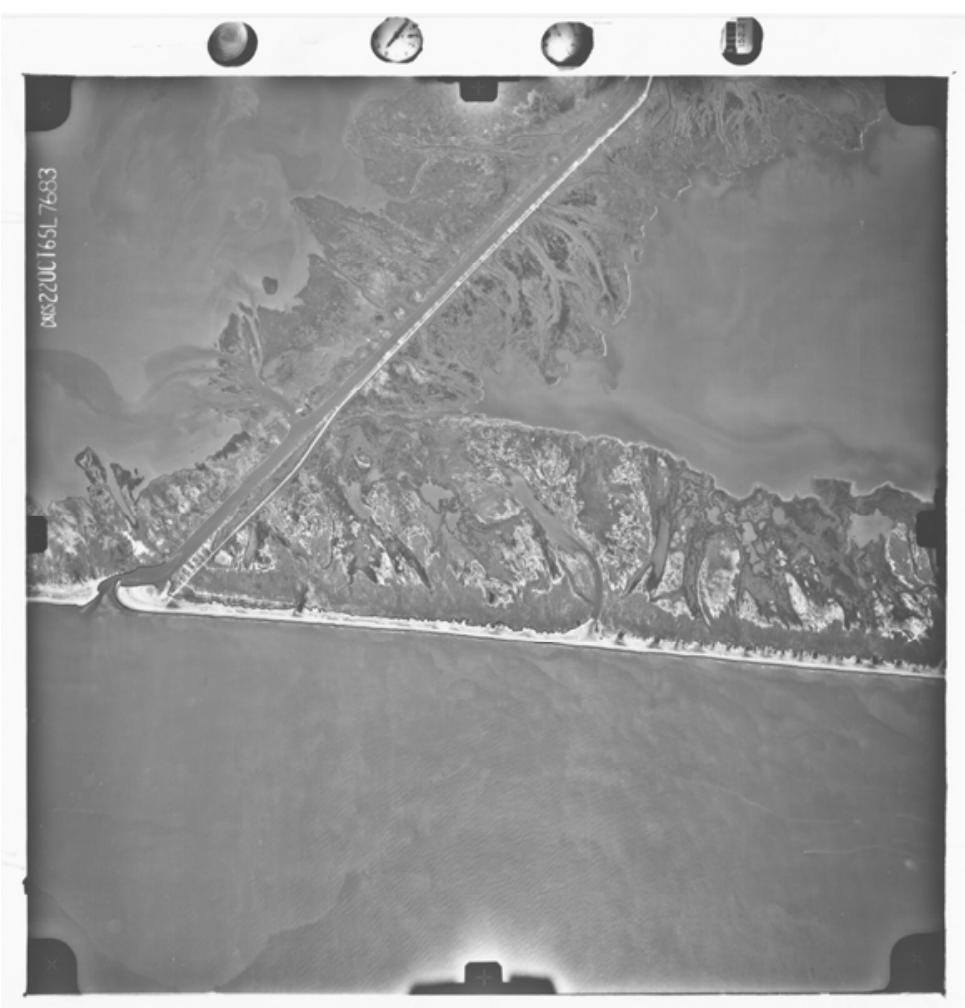

Figure C12. File 65-10-22-MOC.tif, Mouth of Colorado River, 22 October 1965.

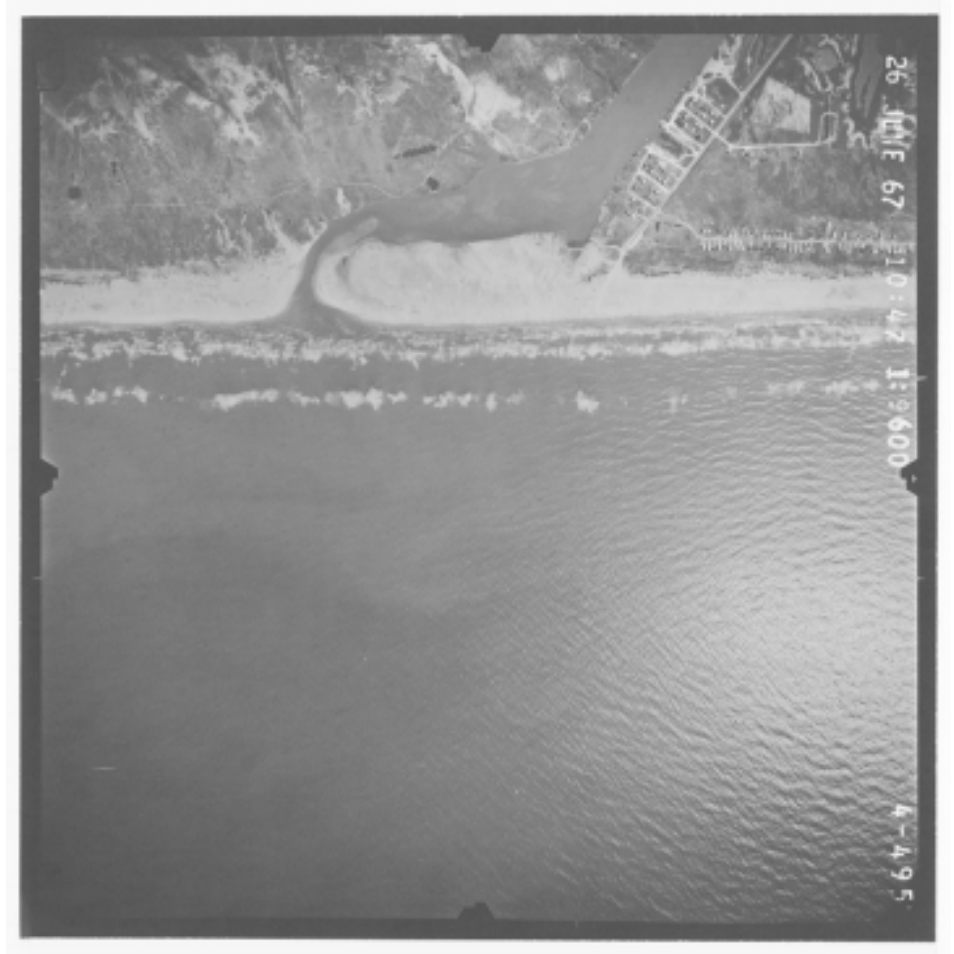

Figure C13. File 67-6-26-MOC.tif, Mouth of Colorado River, 26 June 1967. 


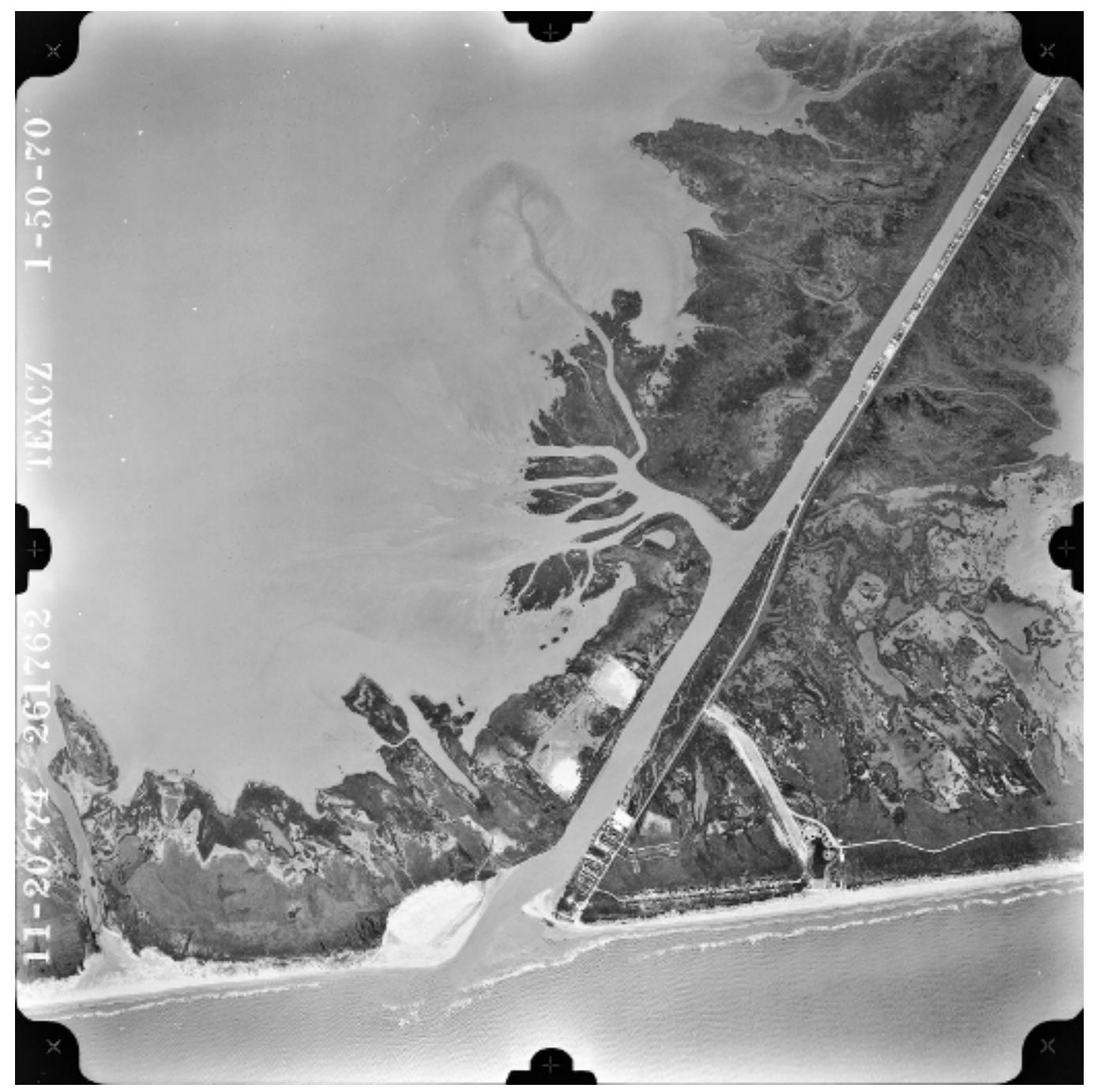

Figure C14. File 74_11_20_MOC.tif, Mouth of Colorado River, 20 November 1974. 


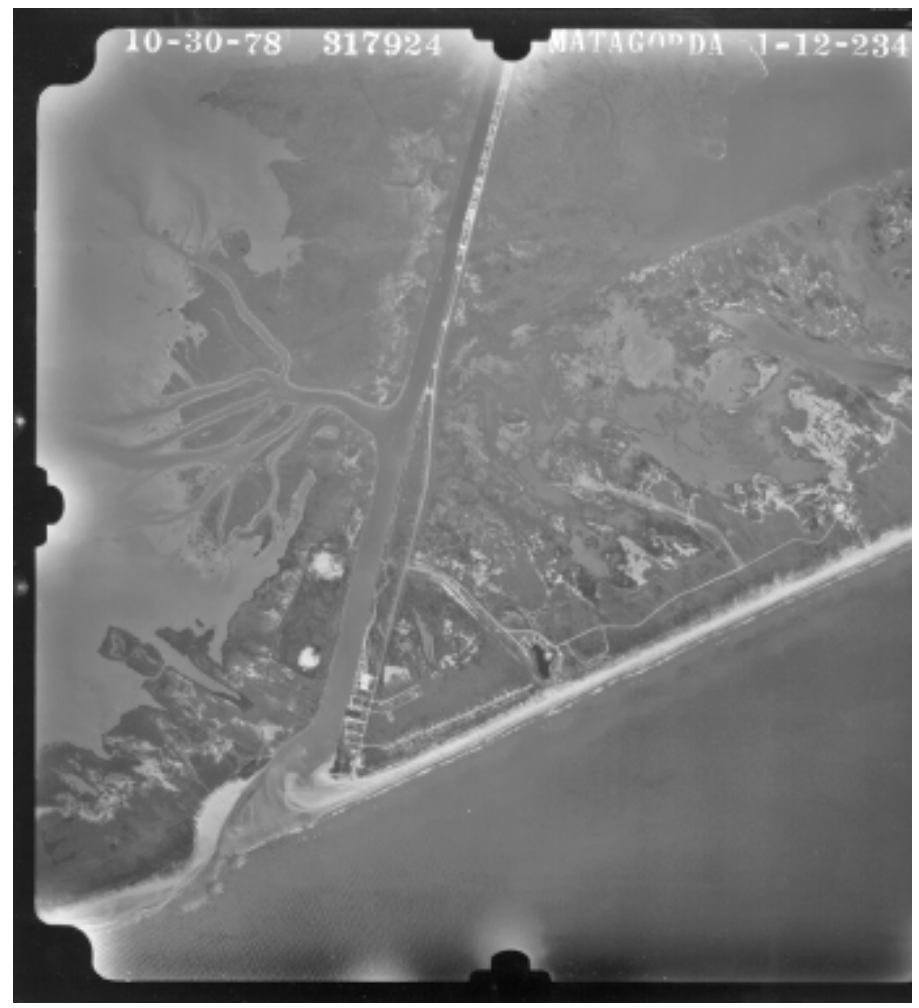

Figure C15. File 78_CR.tif, Mouth of Colorado River, 1978.

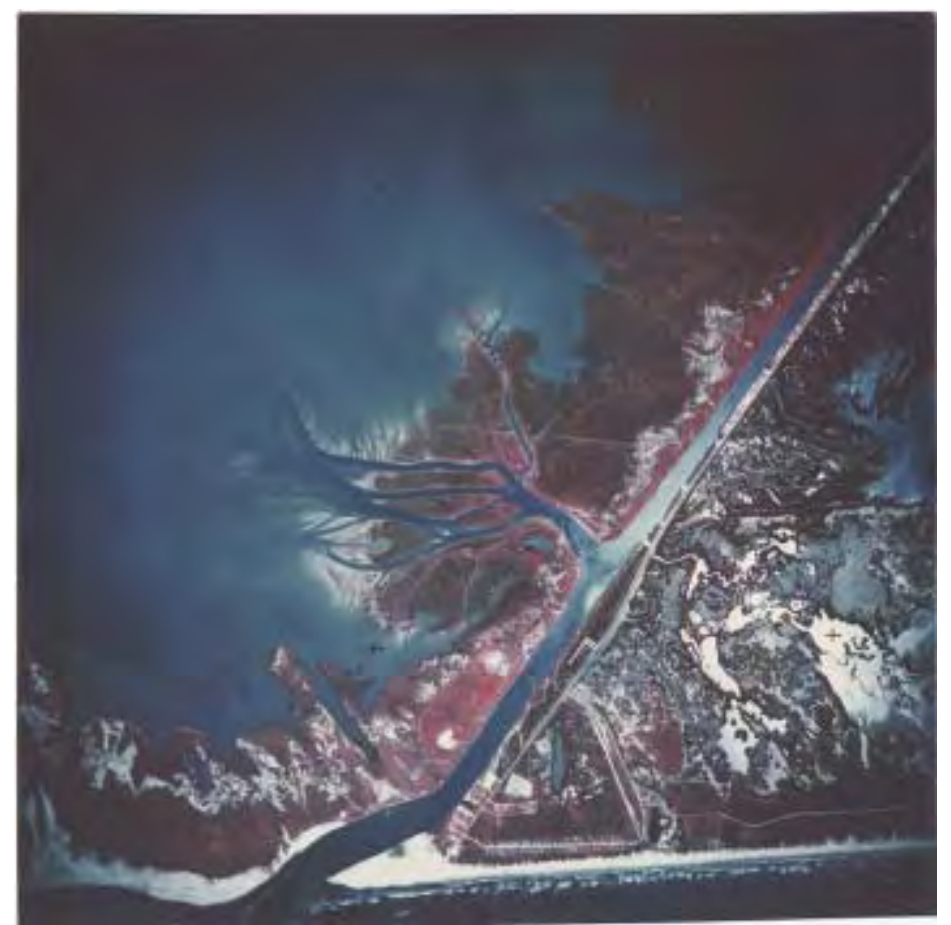

Figure C16. File 82-MOC.tif, Mouth of Colorado River, 1982. 


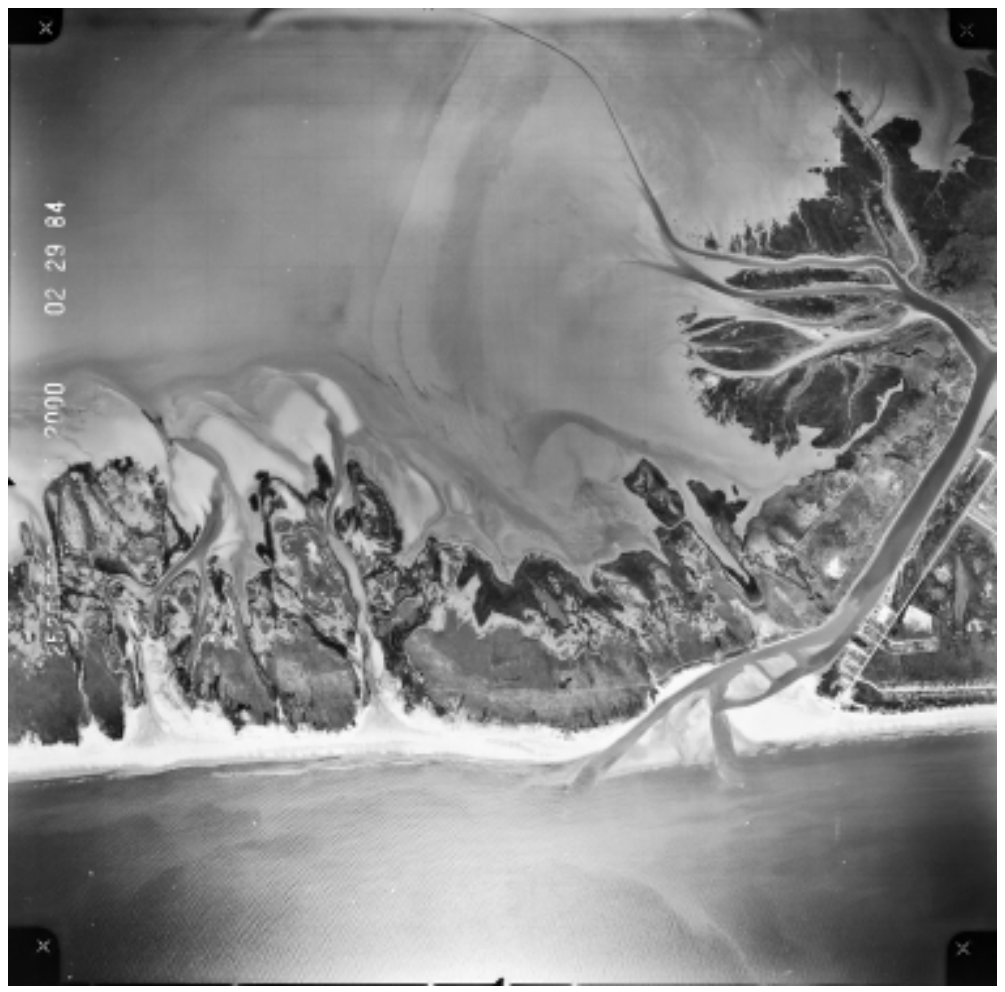

Figure C17. File 84_2_29_MOC.tif, Mouth of Colorado River, 29 February 1984.

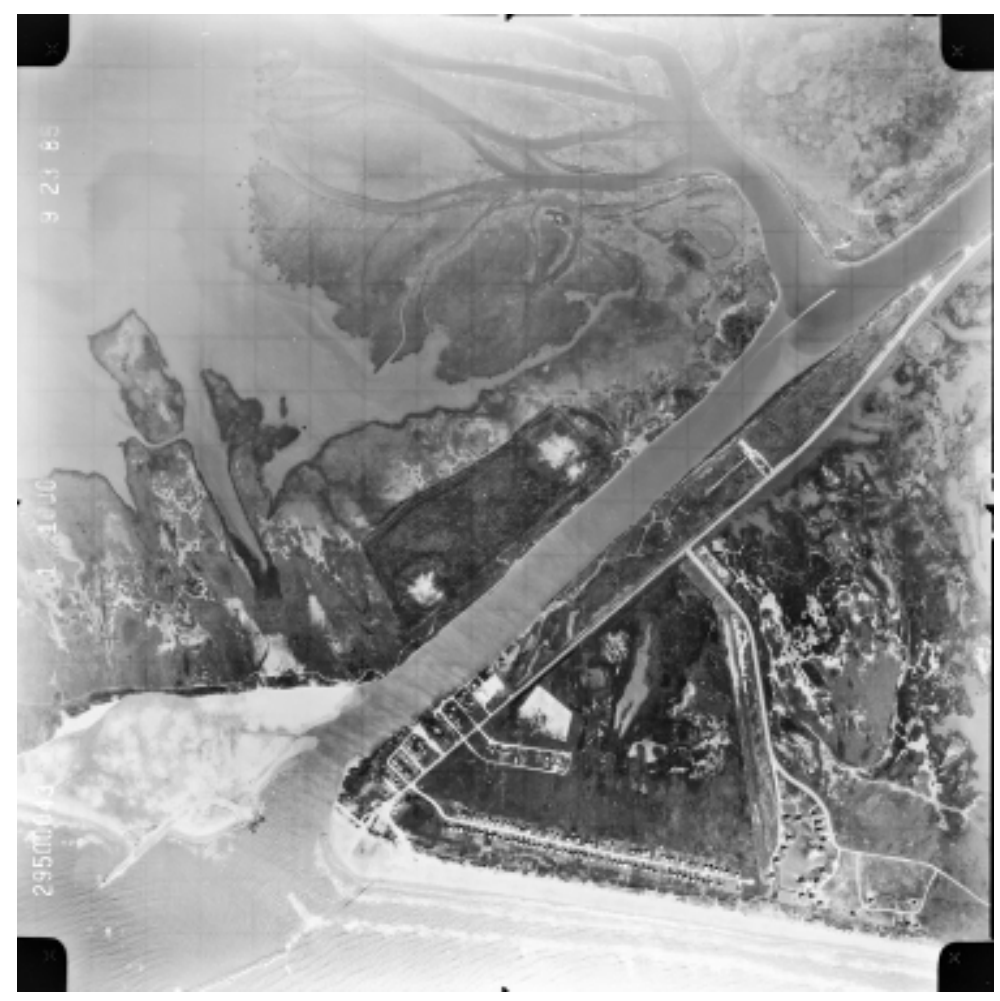

Figure C18. File 85_9_28_MOC.tif, Mouth of Colorado River, 28 September 1985. 


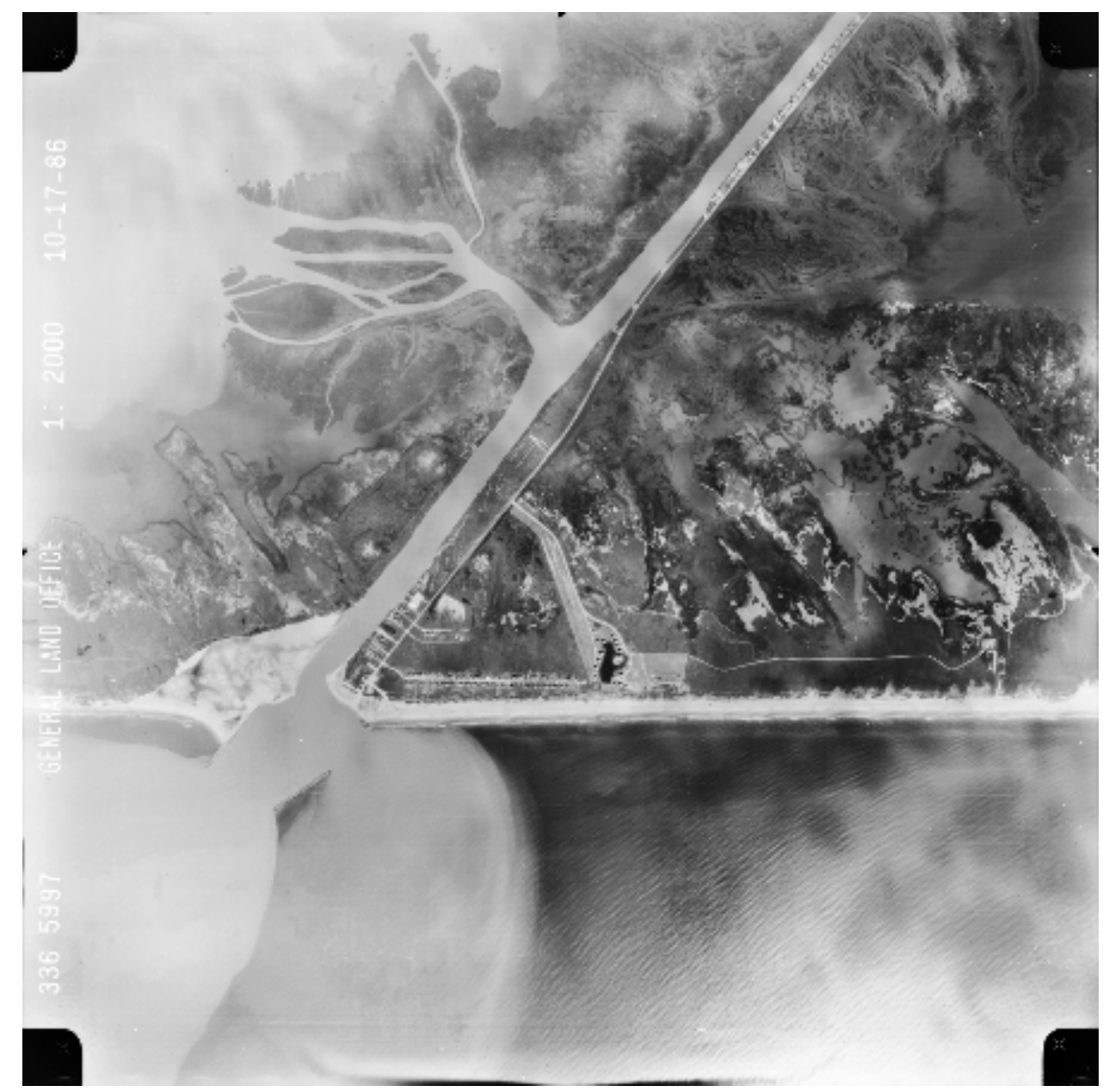

Figure C19. File 86_10_17_MOC.tif, Mouth of Colorado River, 17 October 1986.

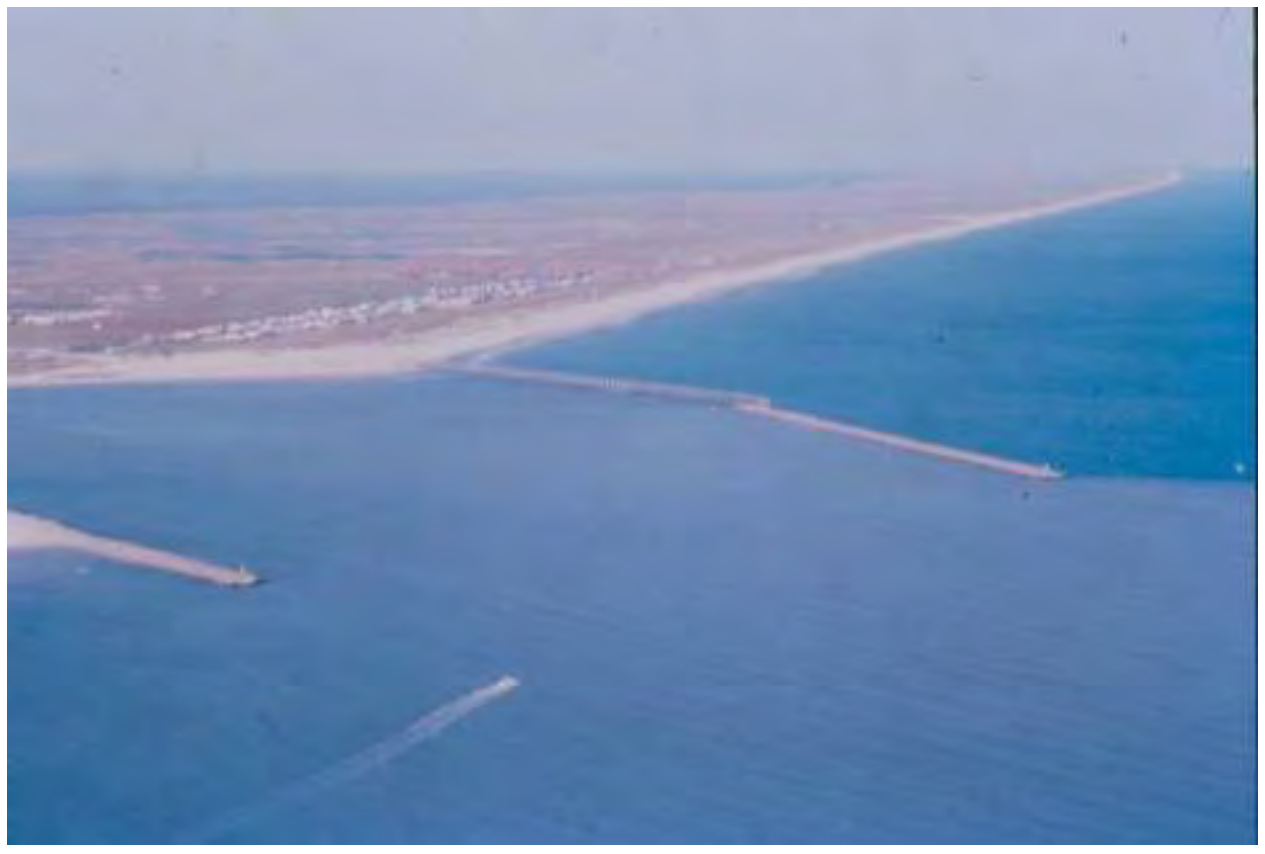

Figure C20. File 90-10B-MOC.jpg, Mouth of Colorado River, October 1990. 


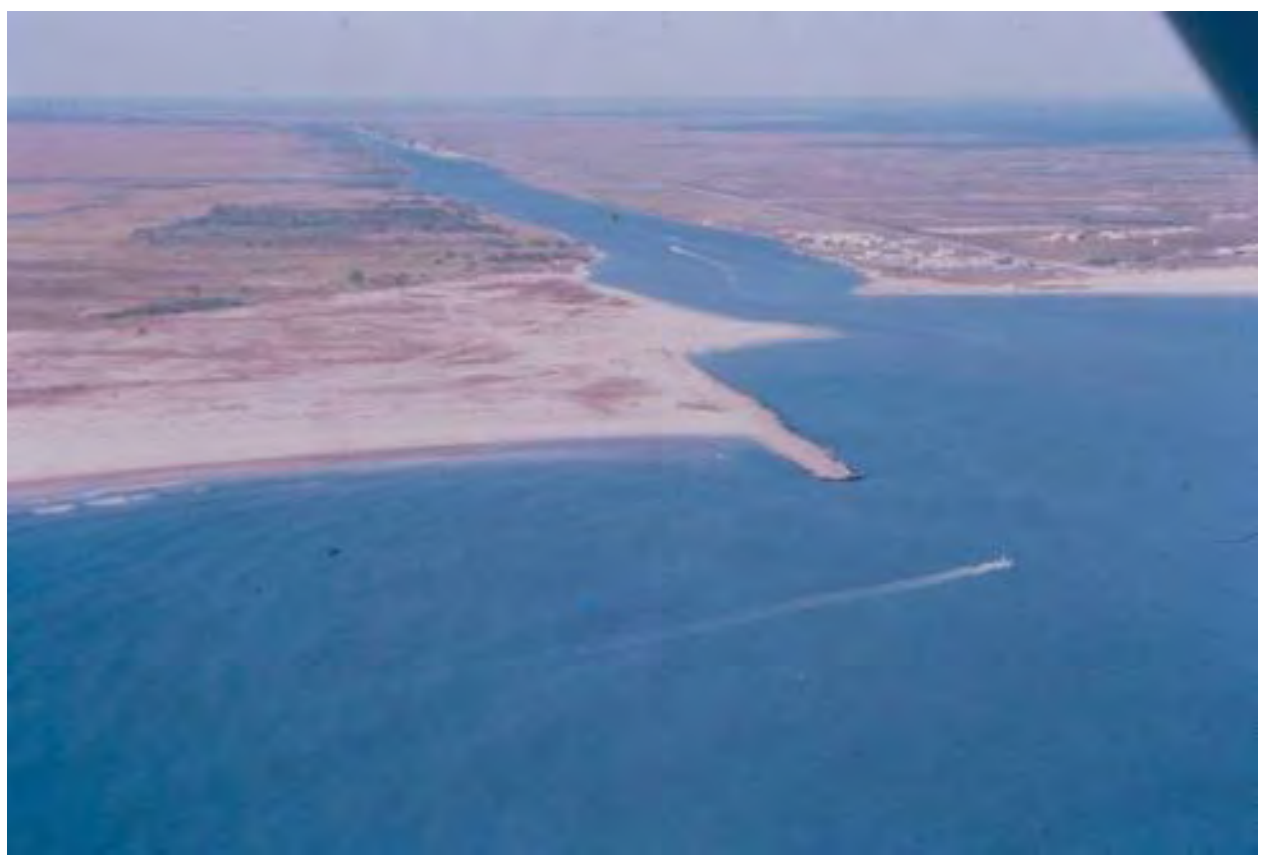

Figure C21. File 90-10C-MOC.jpg, Mouth of Colorado River, October 1990.

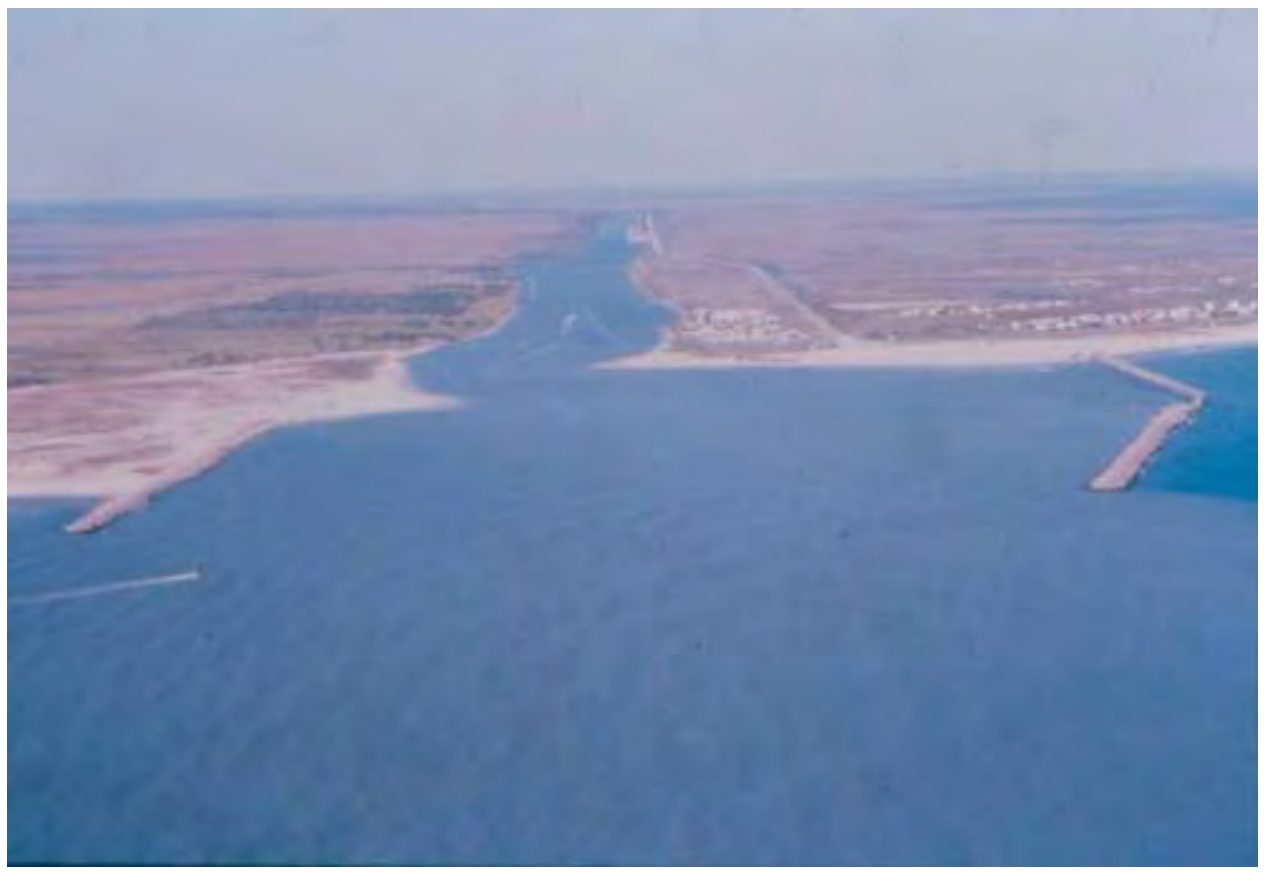

Figure C22. File 90-10D-MOC.jpg, Mouth of Colorado River, October 1990. 


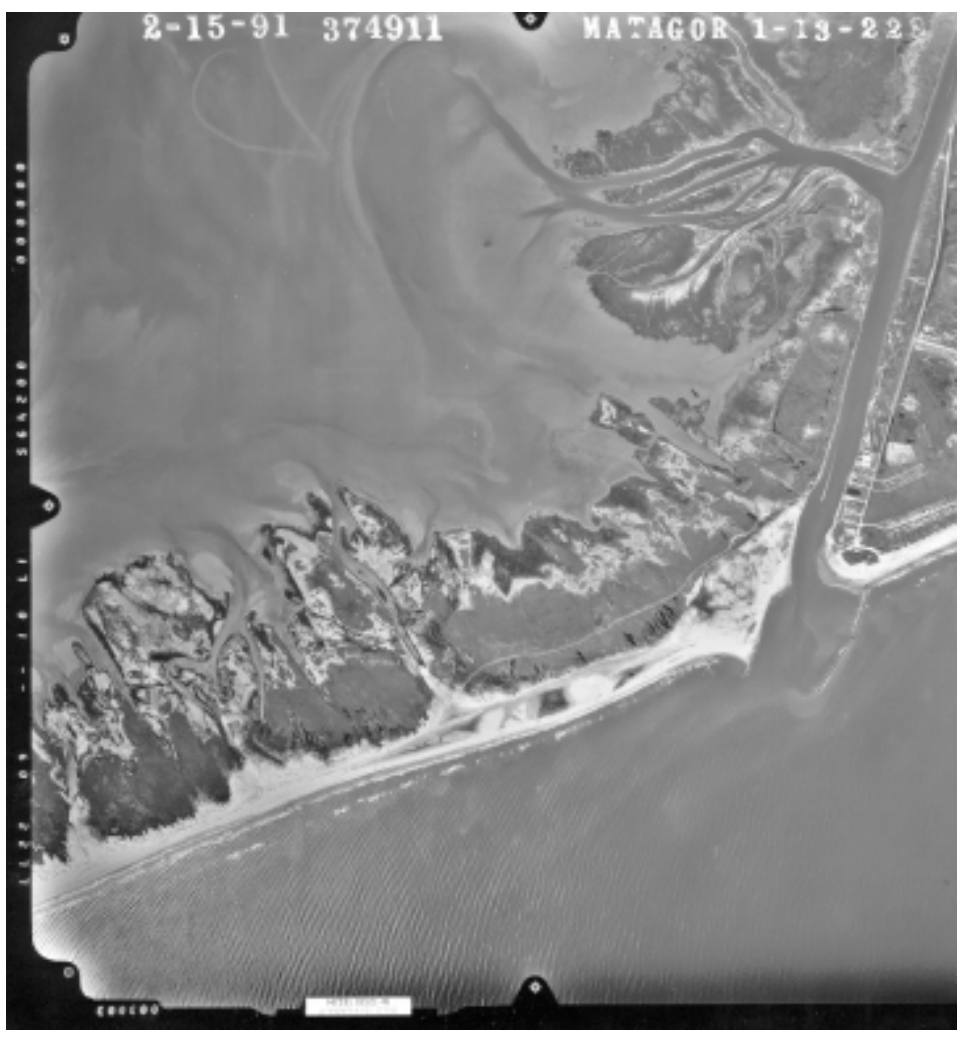

Figure C23. File 91_CR.tif, Mouth of Colorado River, 1991.

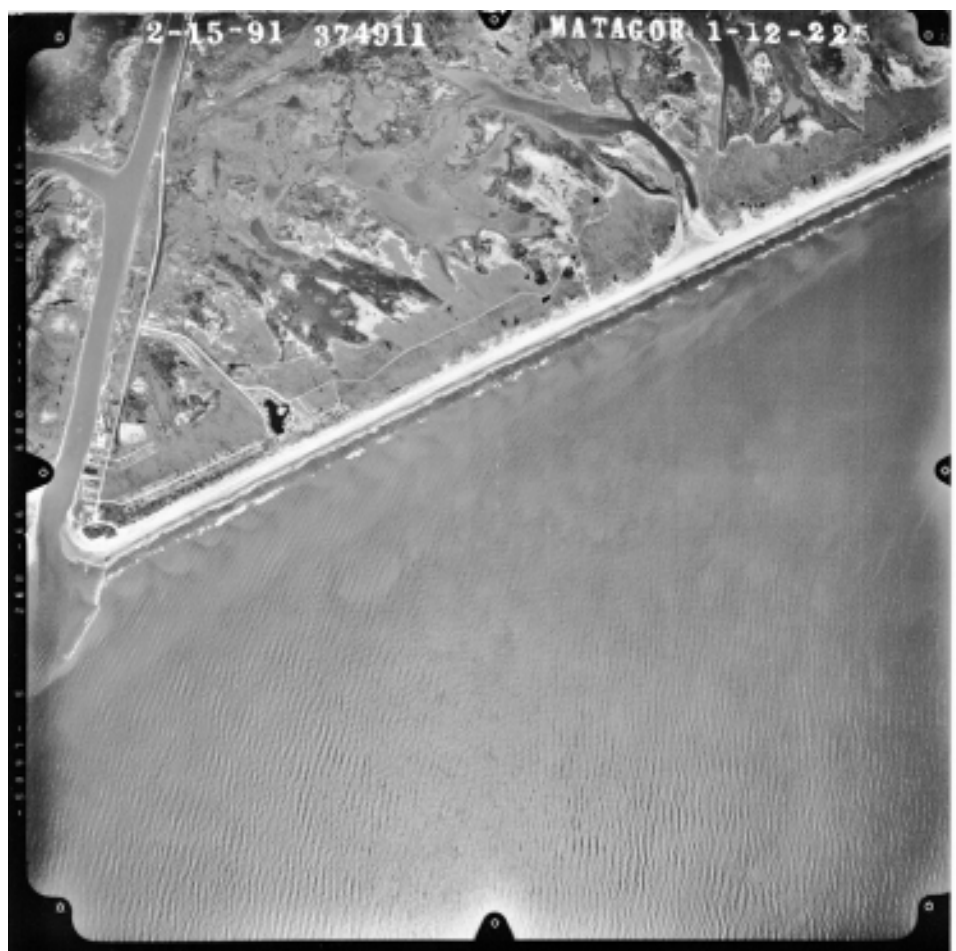

Figure C24. File 91-2-15-MOC.tif, Mouth of Colorado River, 15 February 1991. 


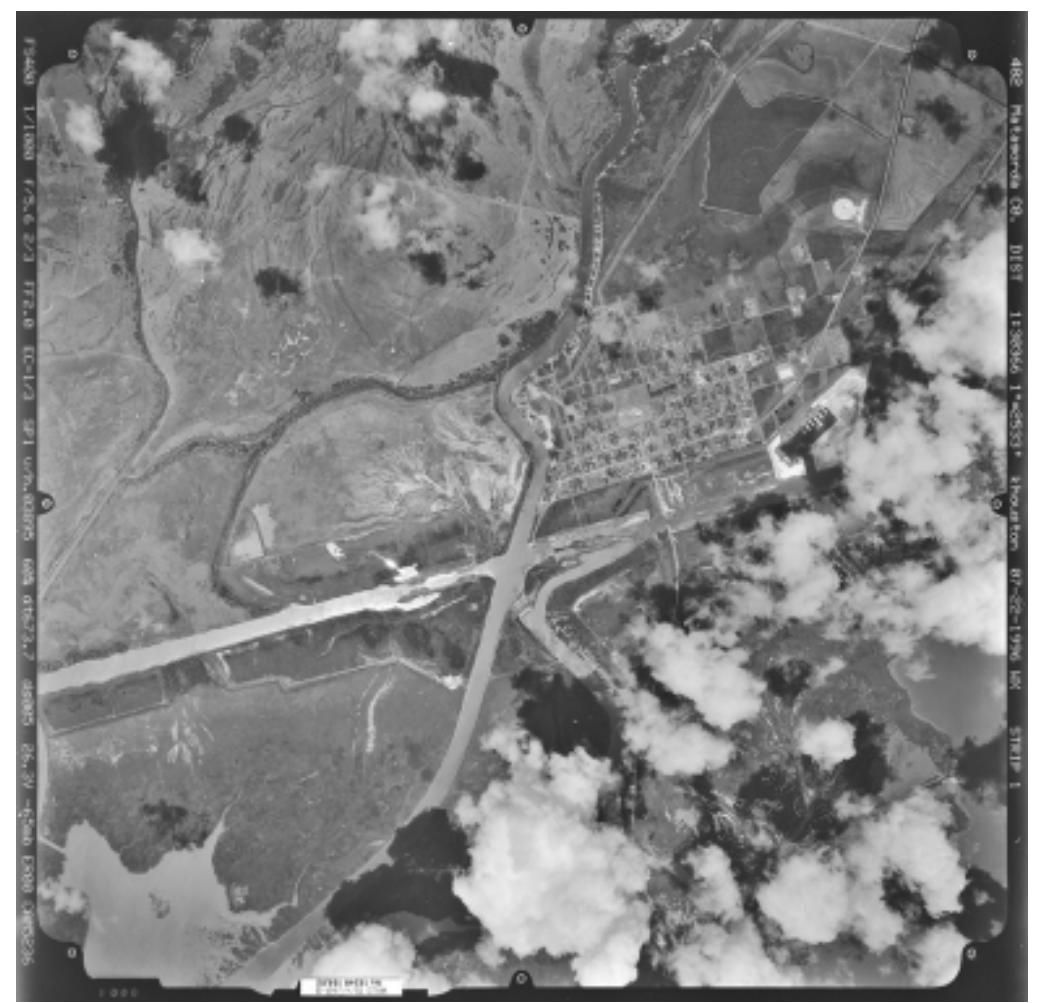

Figure C25. File 96-7-MOC.tif, Colorado River and GIWW Intersection, July 1996.

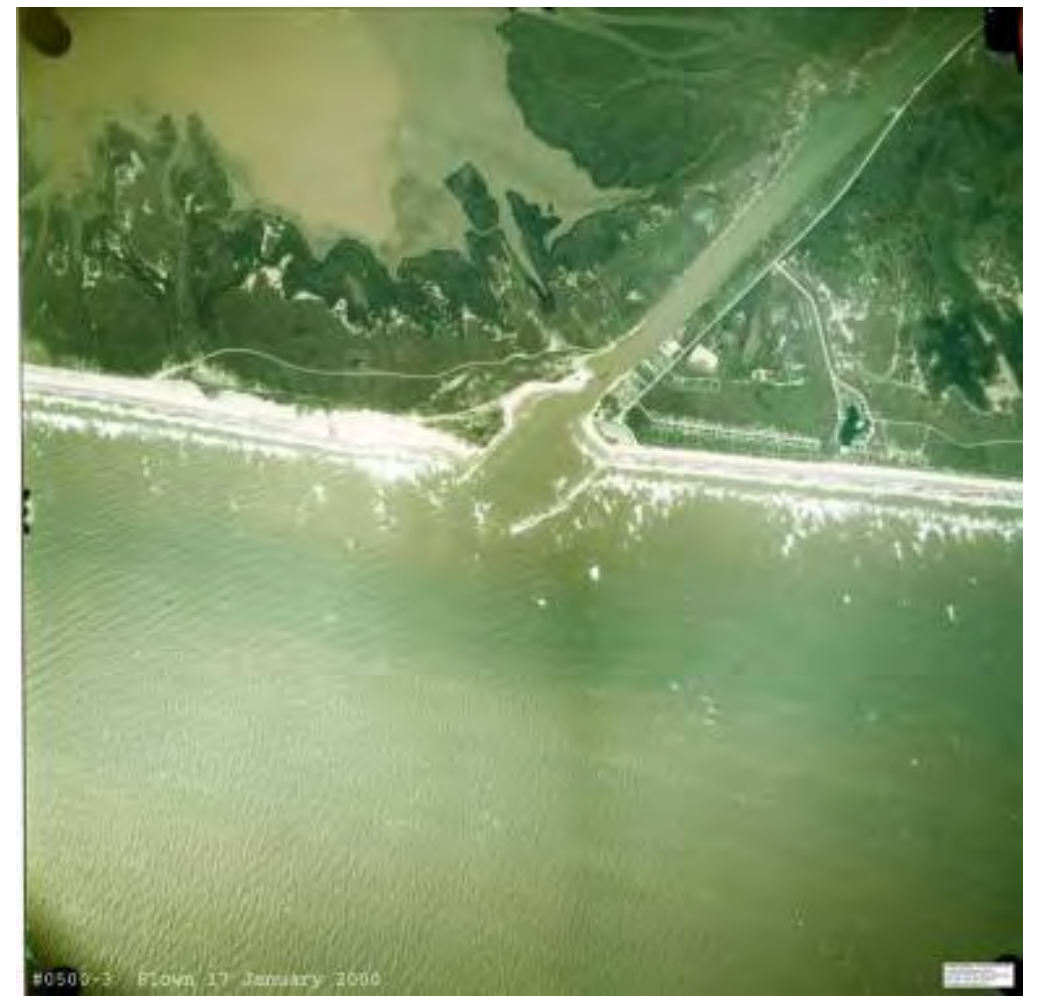

Figure C26. File 00-1-17-MOC.jpg, Mouth of Colorado River, 17 January 2000. 


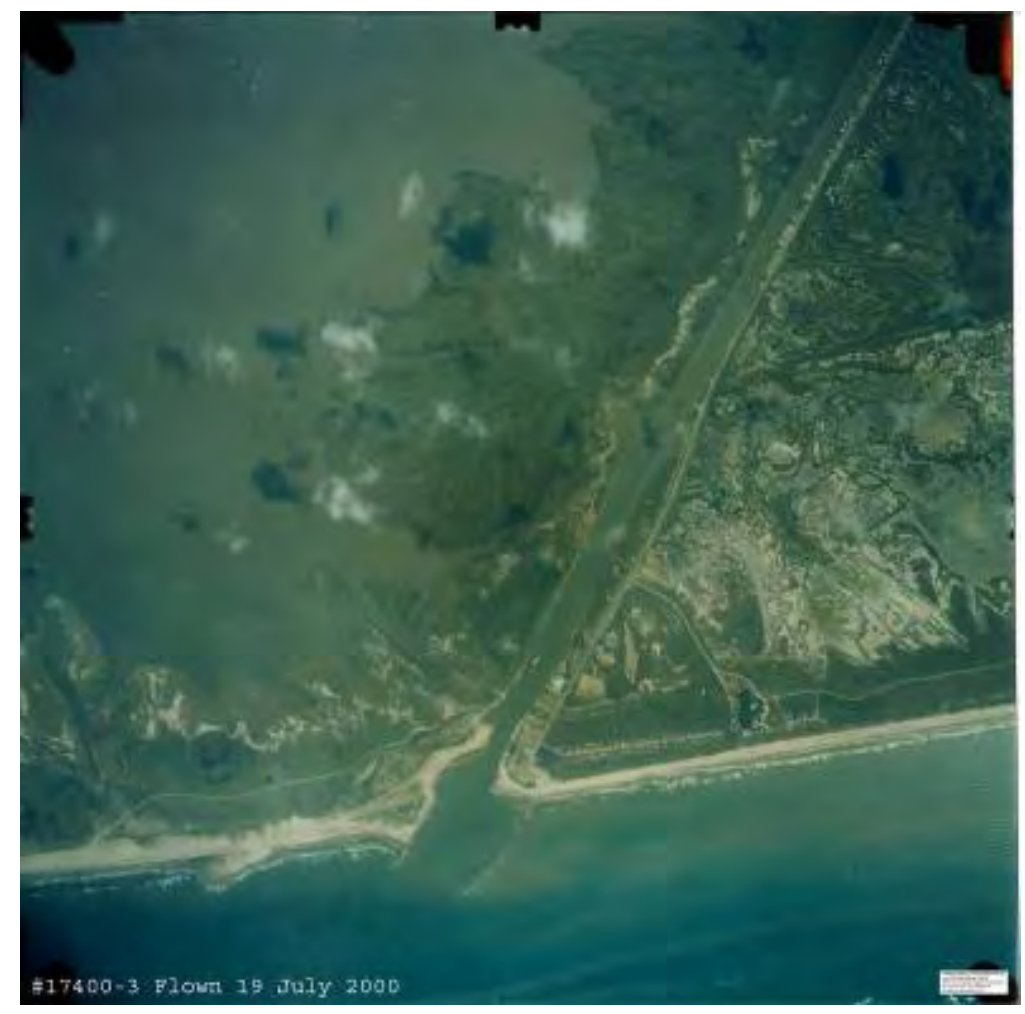

Figure C27. File 00-7-19-MOC.jpg, Mouth of Colorado River, 19 July 2000.

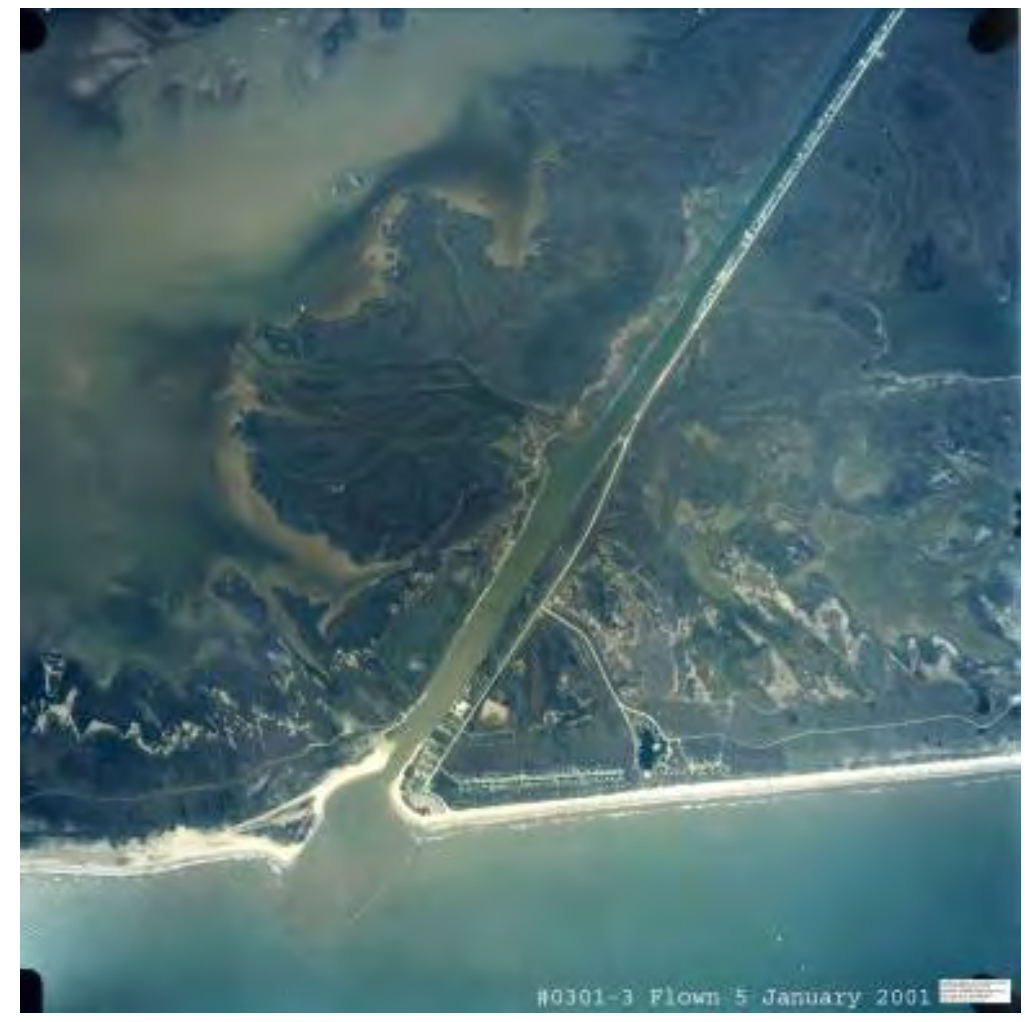

Figure C28. File 01-1-5-MOC.jpg, Mouth of Colorado River, 5 January 2001. 


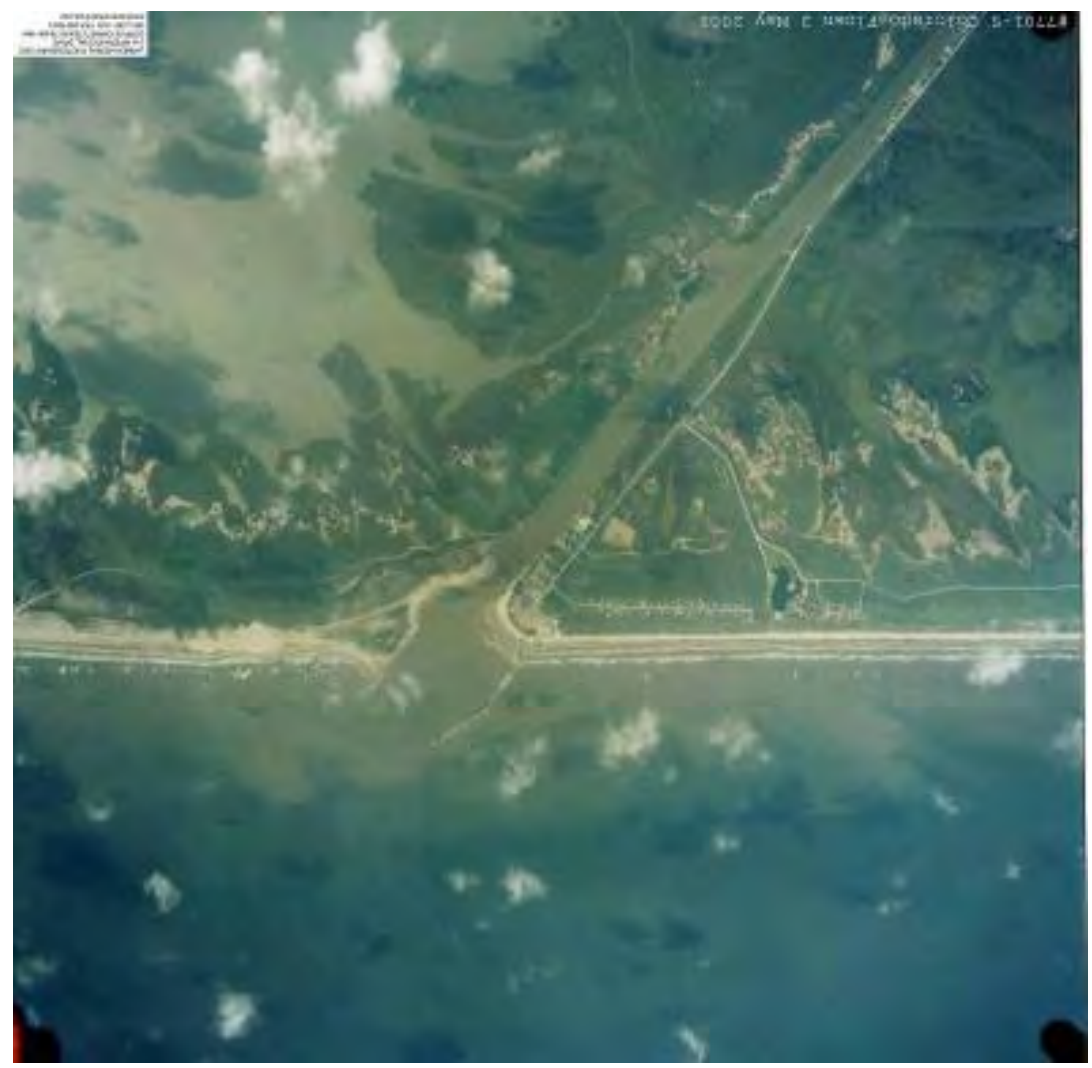

Figure C29. File 01-5-2-MOC.jpg, Mouth of Colorado River, 2 May 2001.

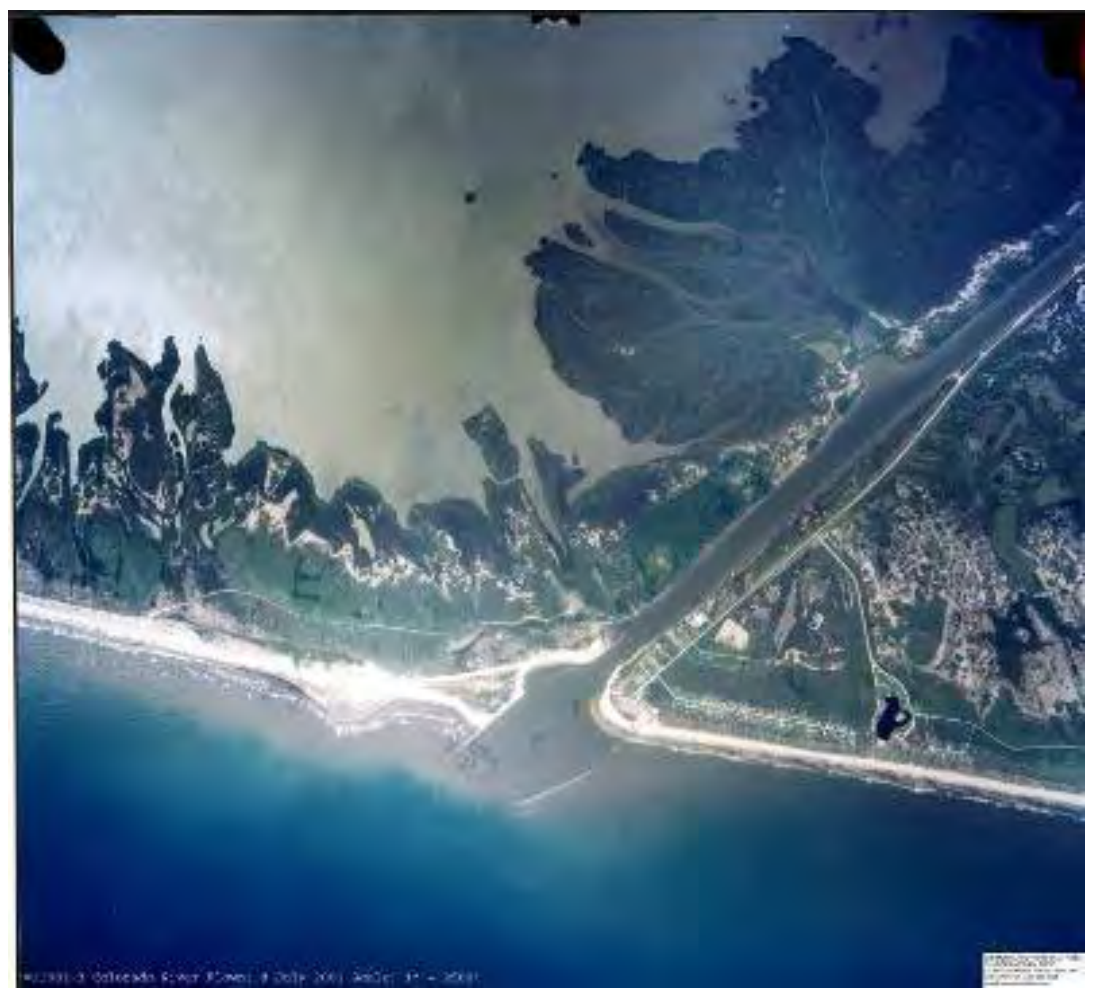

Figure C30. File 01-7-8-MOC.jpg, Mouth of Colorado River, 8 July 2001. 


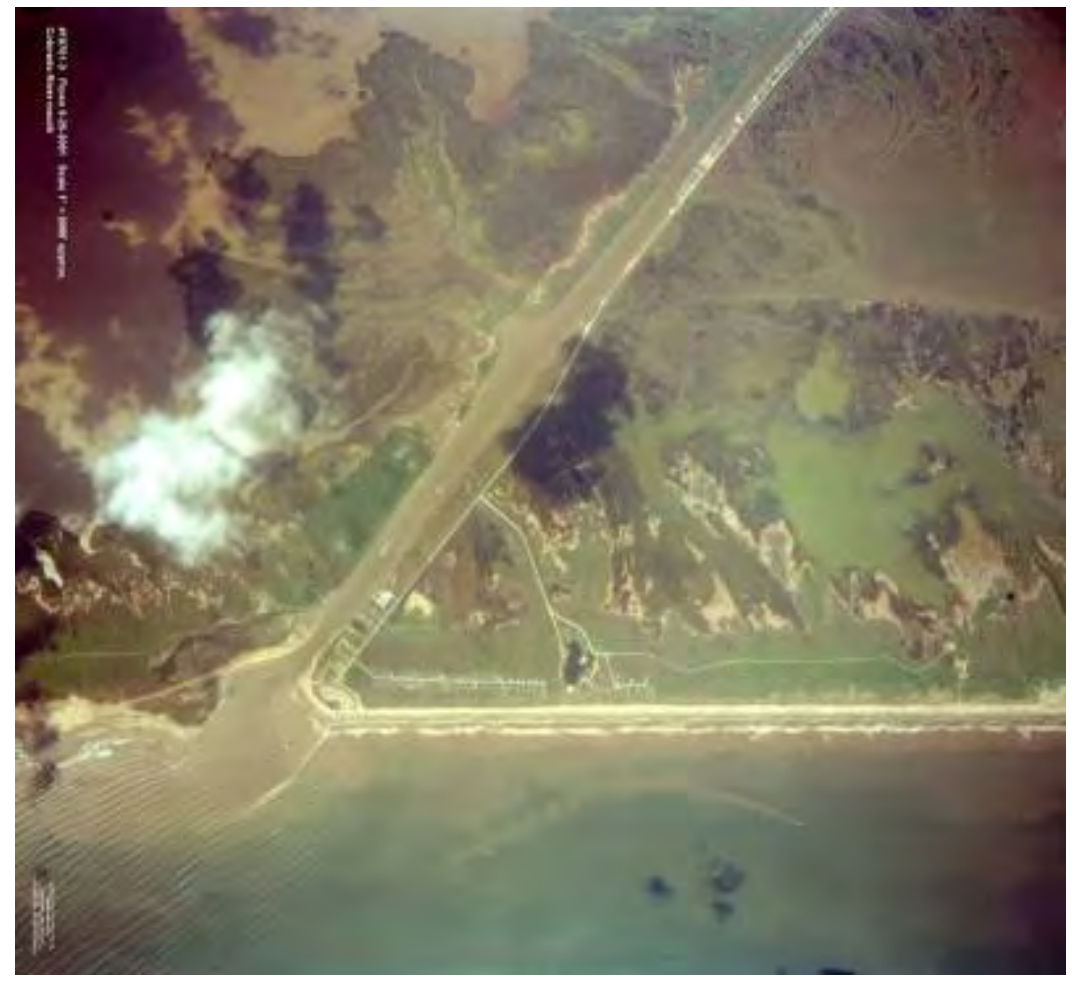

Figure C31. File 01-9-26-MOC.jpg, Mouth of Colorado River, 26 September 2001.

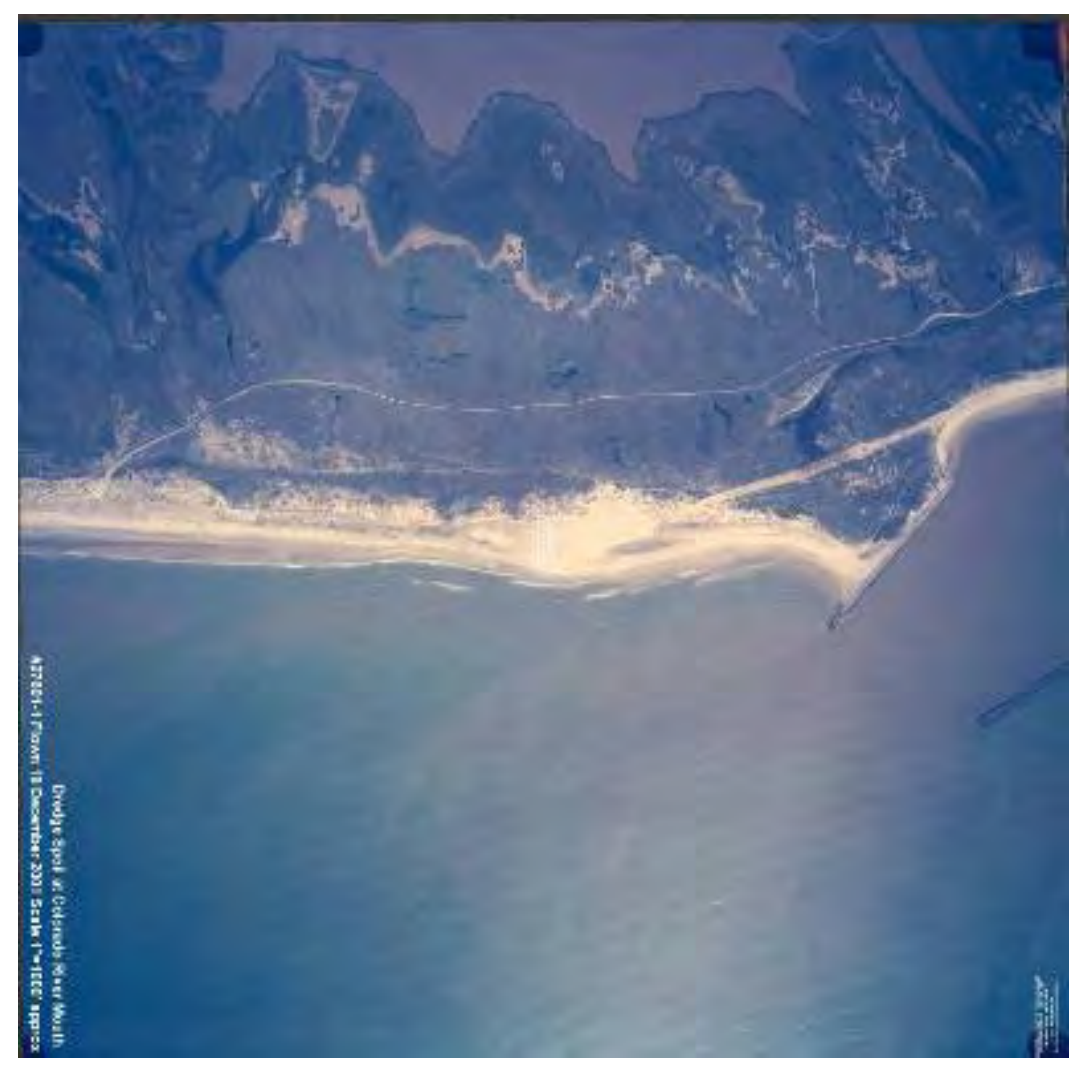

Figure C32. File 01-12-19-MOC-A.jpg, Mouth of Colorado River, 19 December 2001. 


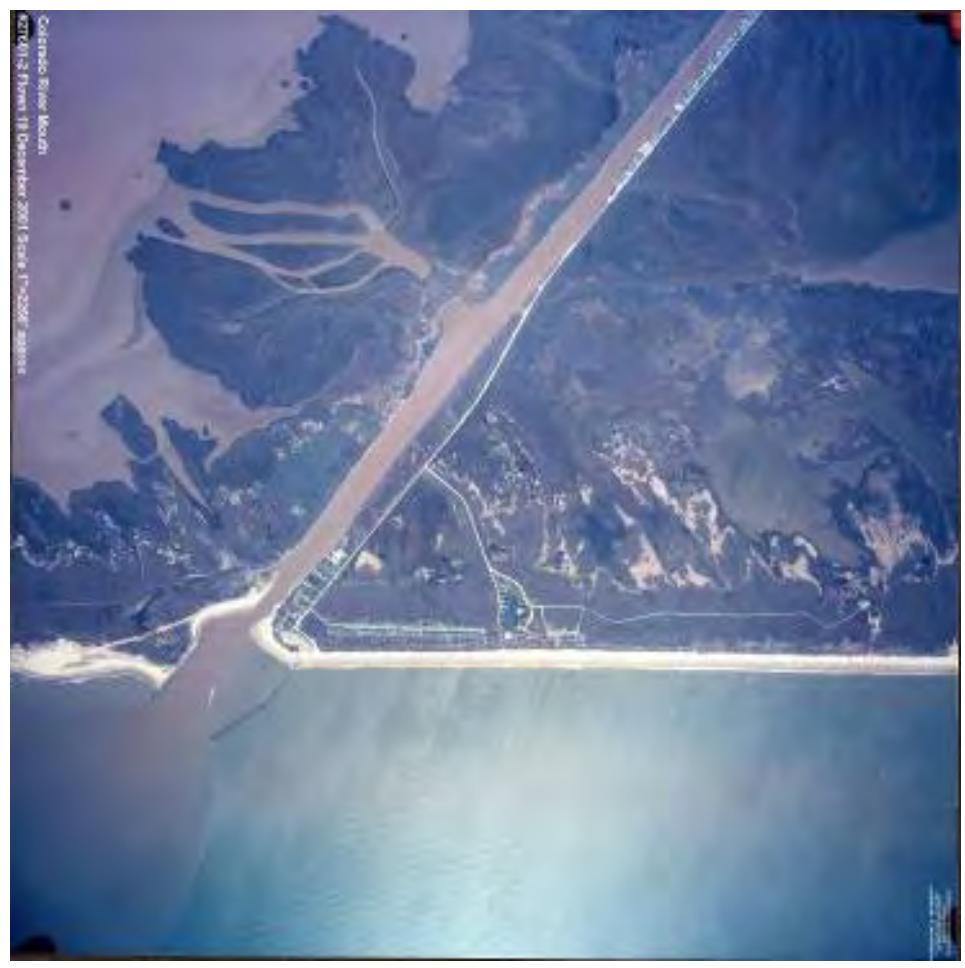

Figure C33. File 01-12-19-MOC-B.jpg, Mouth of Colorado River, 19 December 2001.

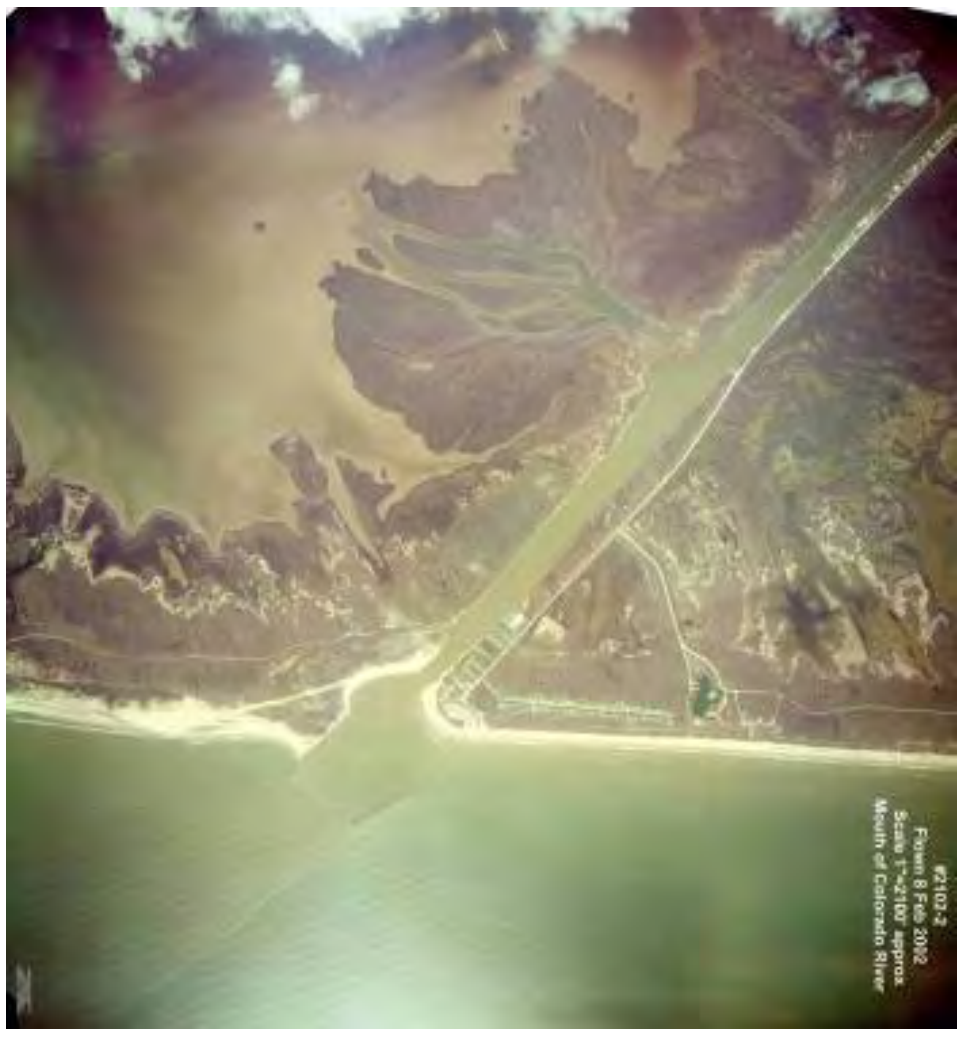

Figure C34. File 02-8-2-MOC.jpg, Mouth of Colorado River, 2 August 2002. 


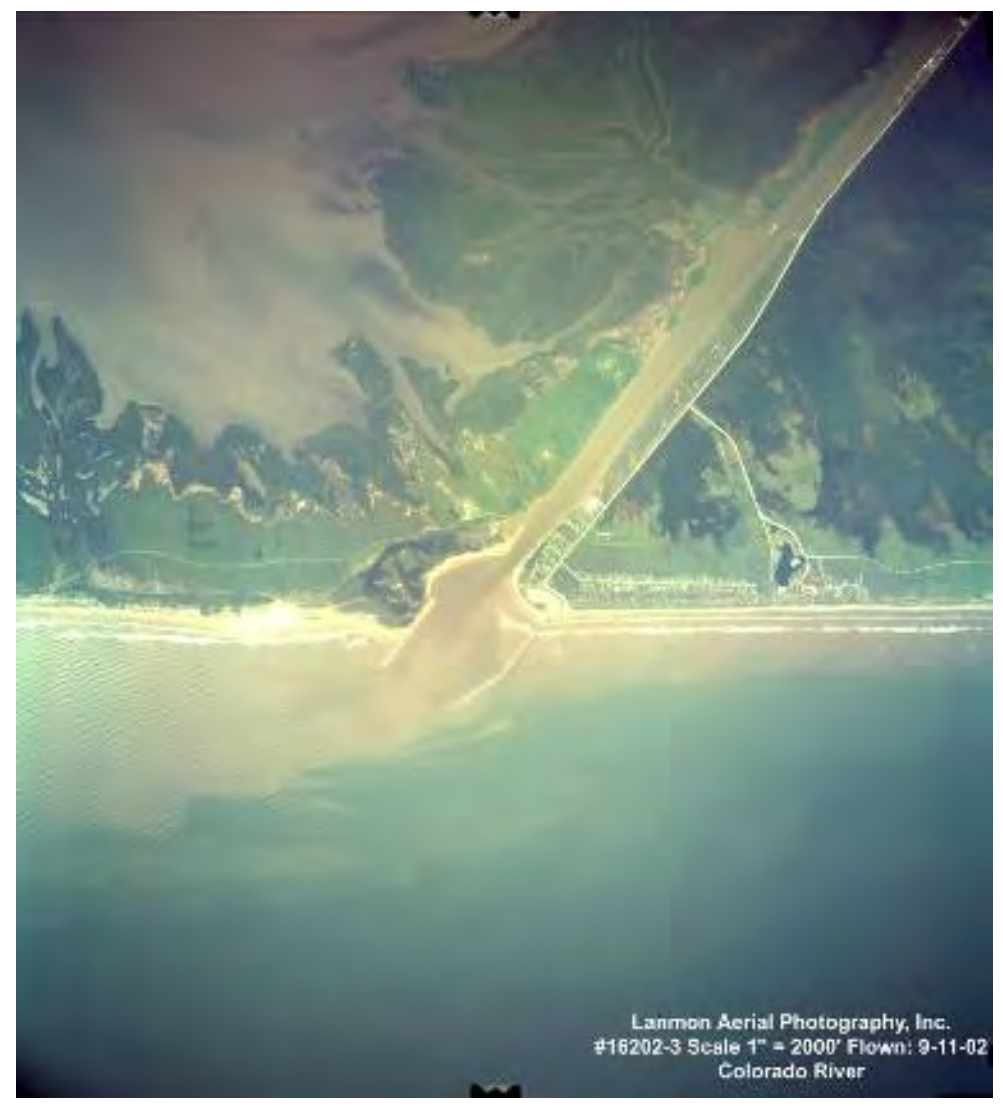

Figure C35. File 02-9-11-MOC.jpg, Mouth of Colorado River, 11 September 2002.

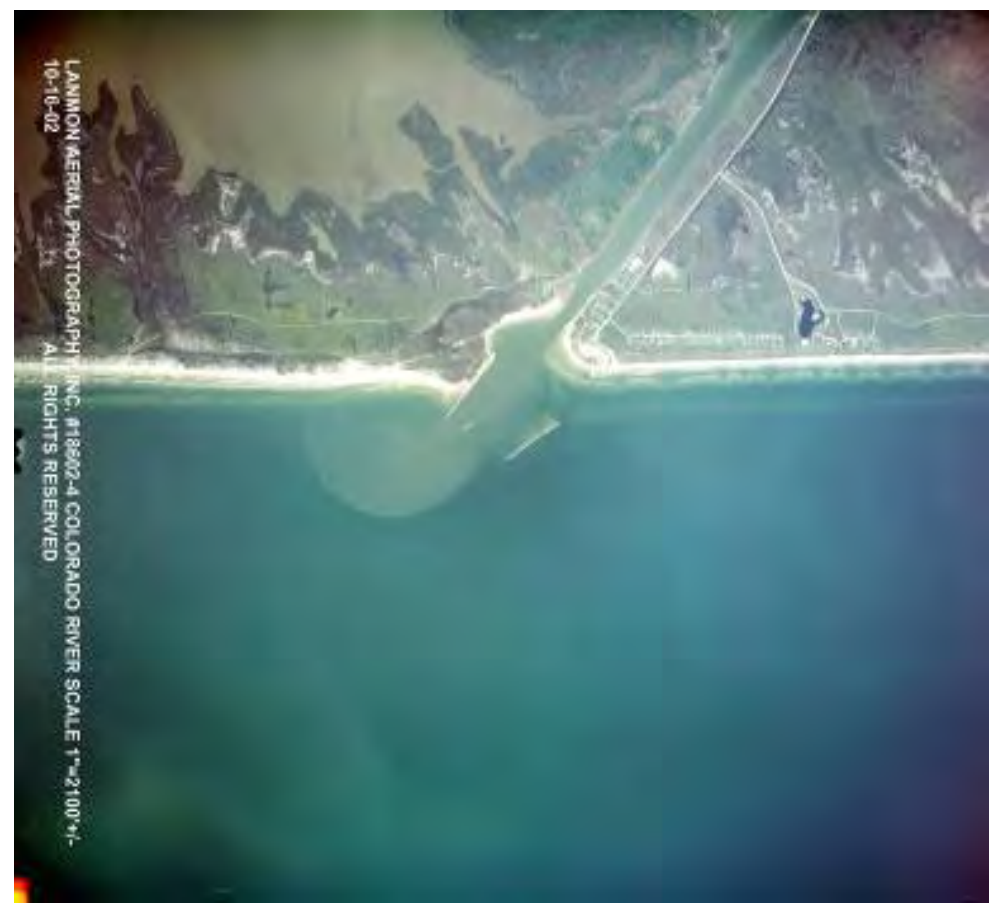

Figure C36. File 02-10-16-MOC.jpg, Mouth of Colorado River, 16 October 2002. 


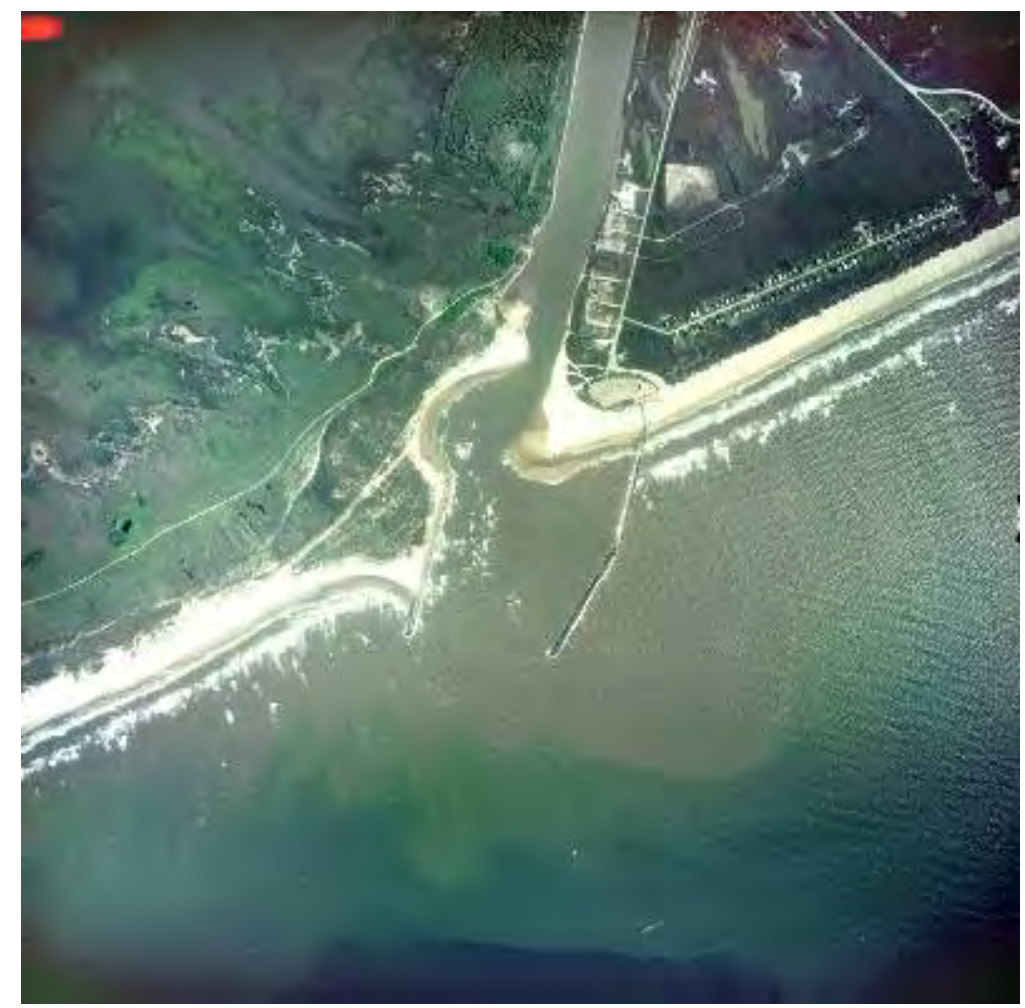

Figure C37. File 03-4-16-MOC.jpg, Mouth of Colorado River, 16 April 2003.

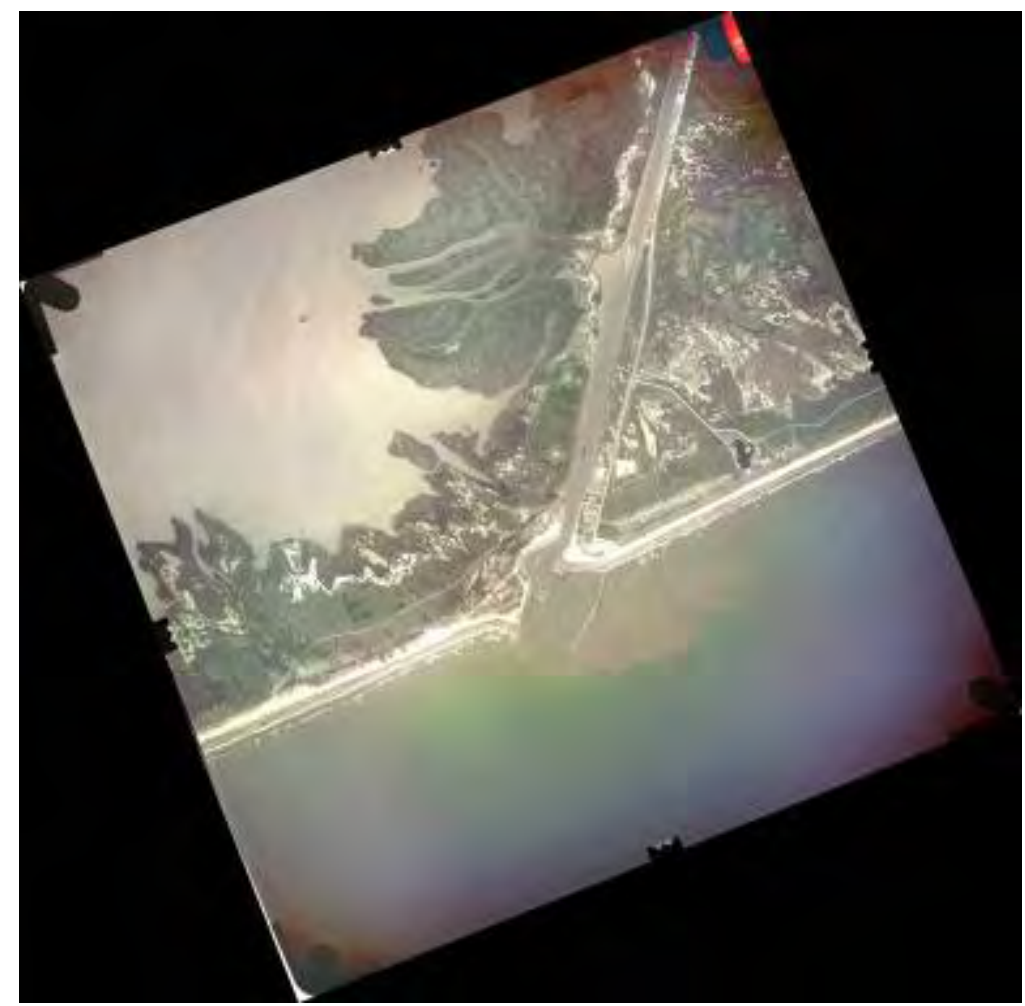

Figure C38. File 03-5-30-MOC-A.jpg, Mouth of Colorado River, 30 May 2003. 


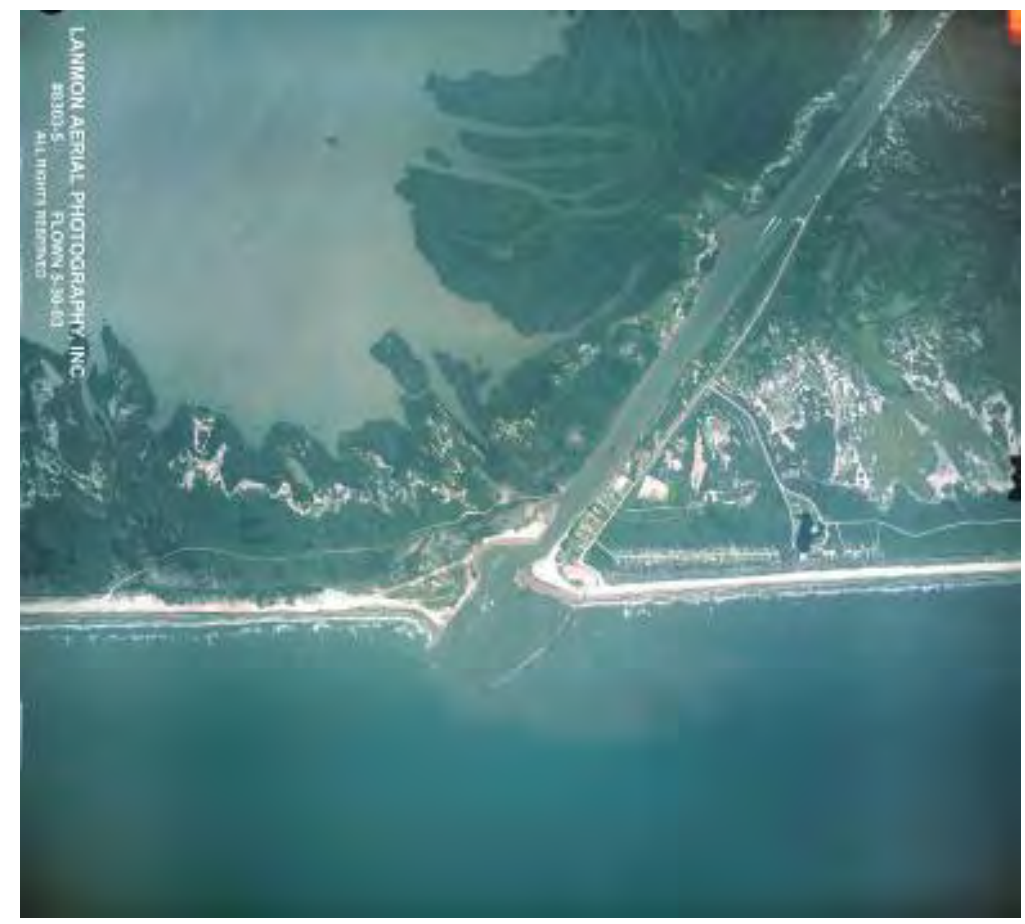

Figure C39. File 03-5-30-MOC-B.jpg, Mouth of Colorado River, 30 May 2003.

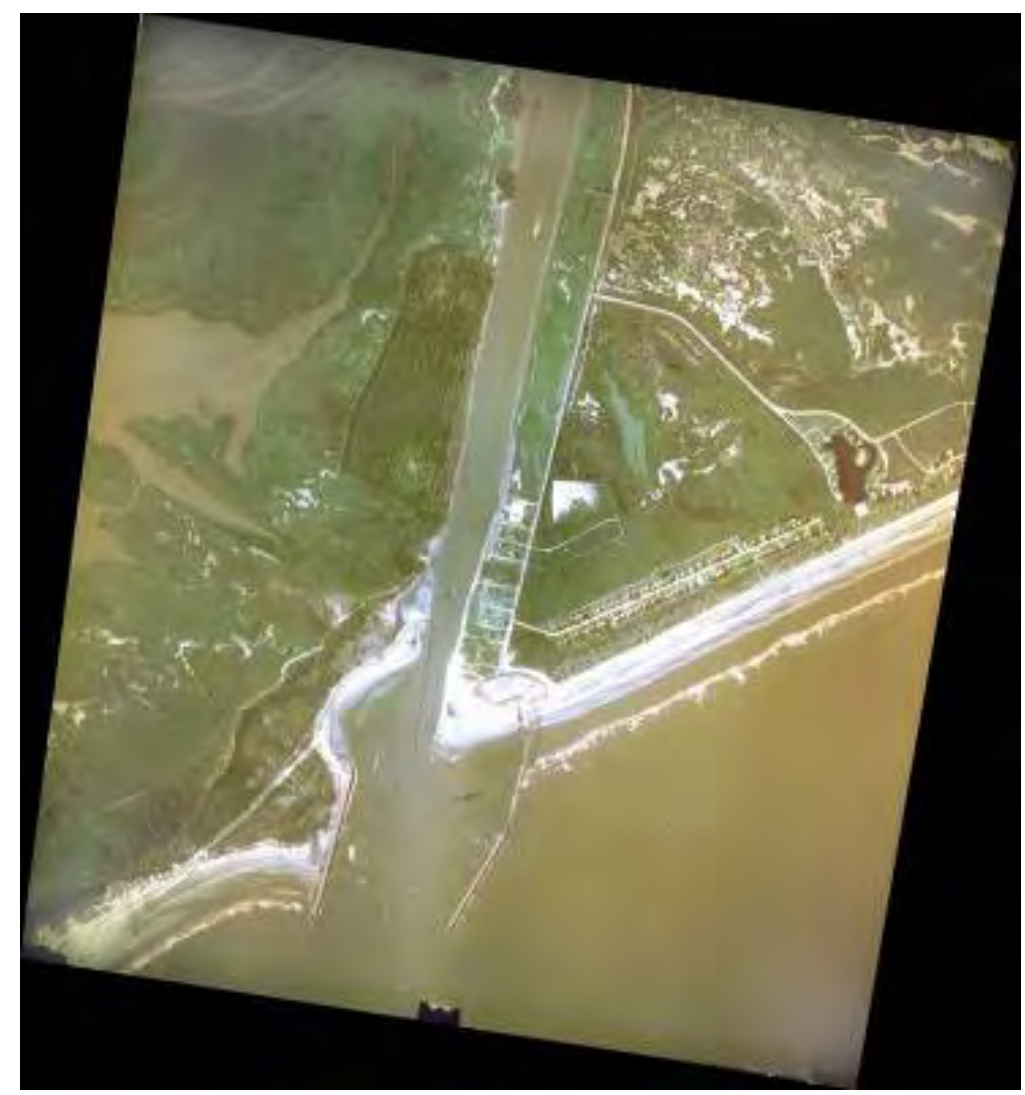

Figure C40. File 03-8-6-MOC-A.jpg, Mouth of Colorado River, 6 August 2003. 


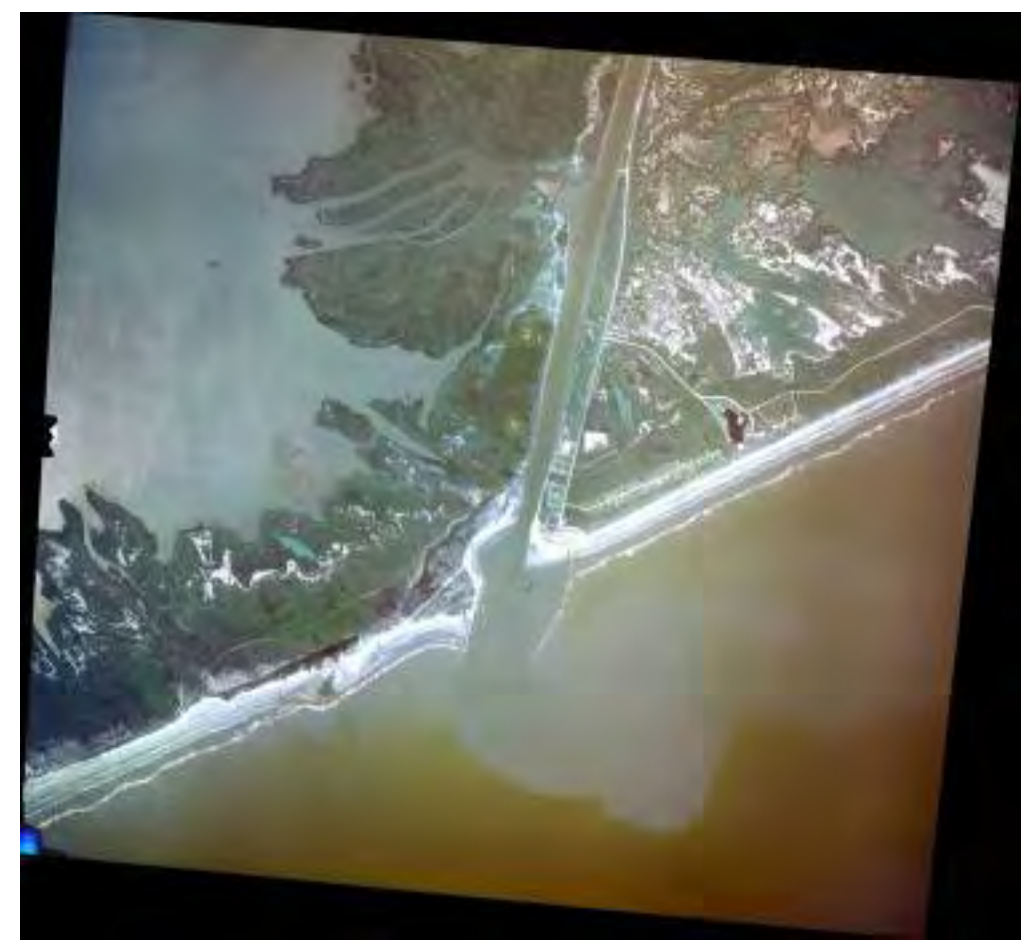

Figure C41. File 03-8-6-MOC-B.jpg, Mouth of Colorado River, 6 August 2003.

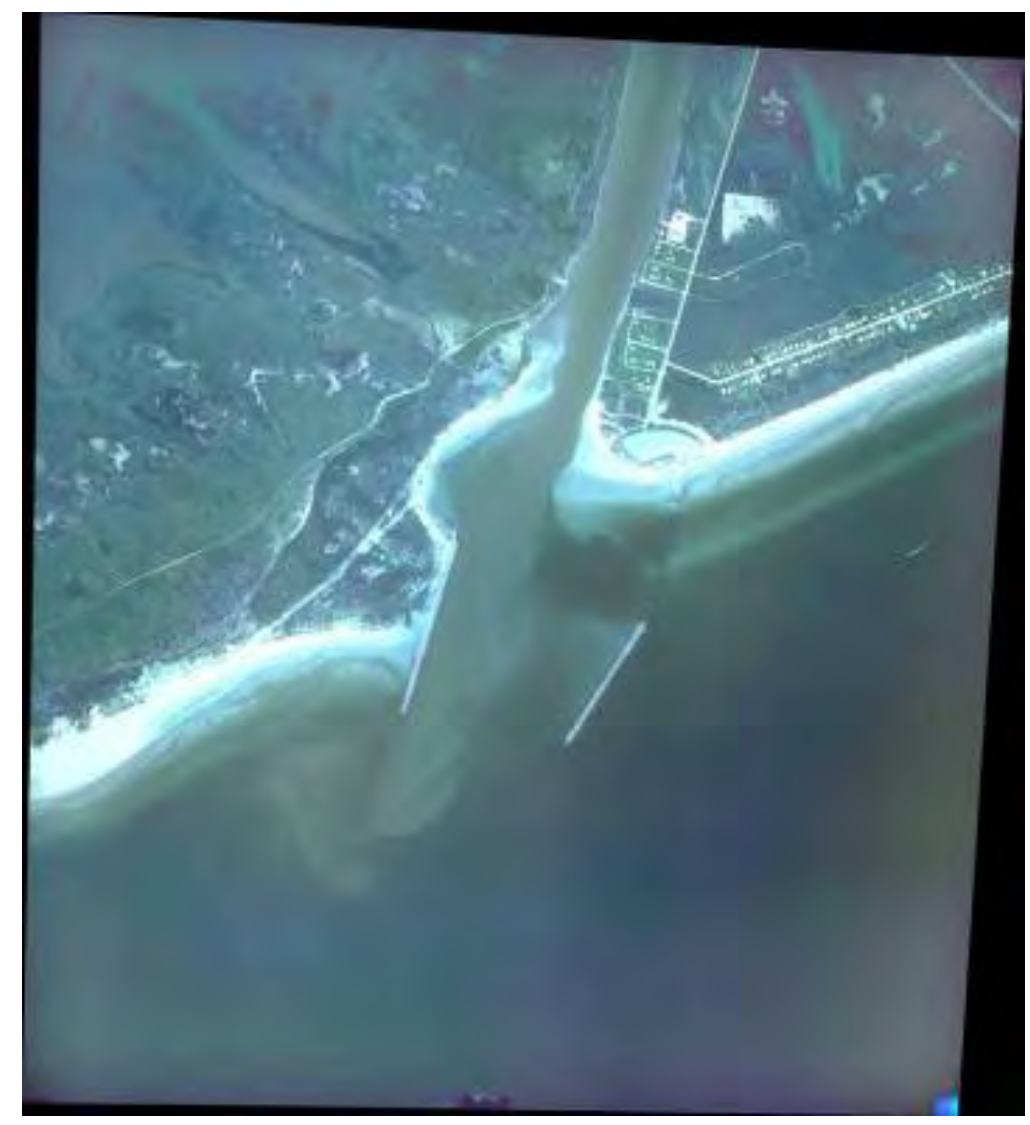

Figure C42. File 03-9-8-MOC-A.jpg, Mouth of Colorado River, 8 September 2003. 


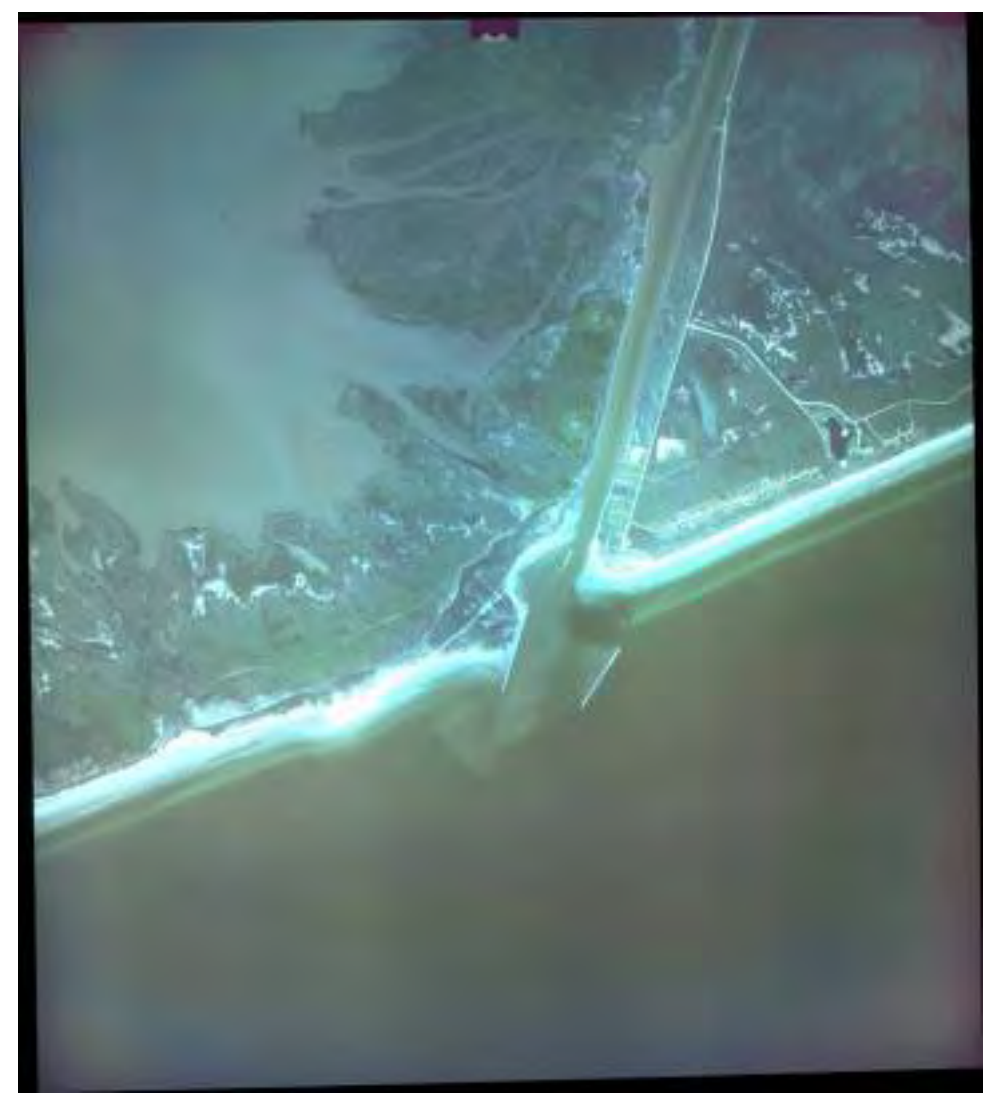

Figure C43. File 03-9-8-MOC-B.jpg, Mouth of Colorado River, 8 September 2003.

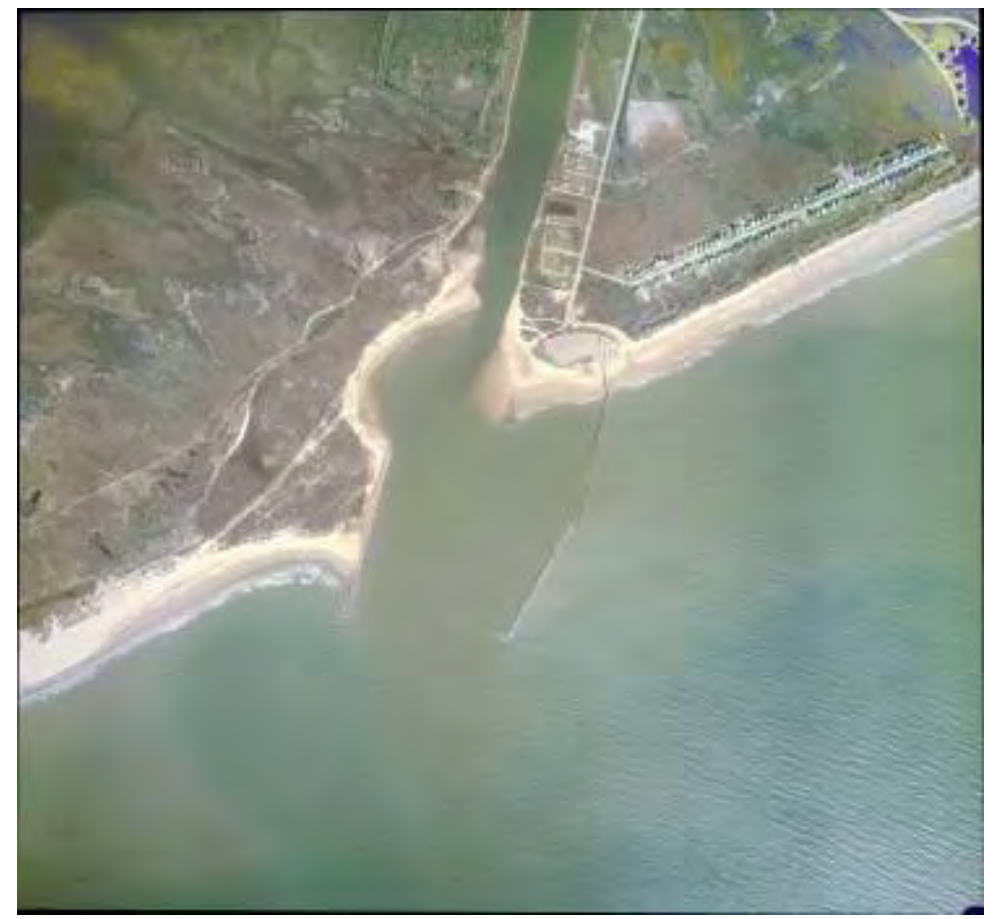

Figure C44. File 03-12-18-MOC-A.jpg, Mouth of Colorado River, 18 December 2003. 


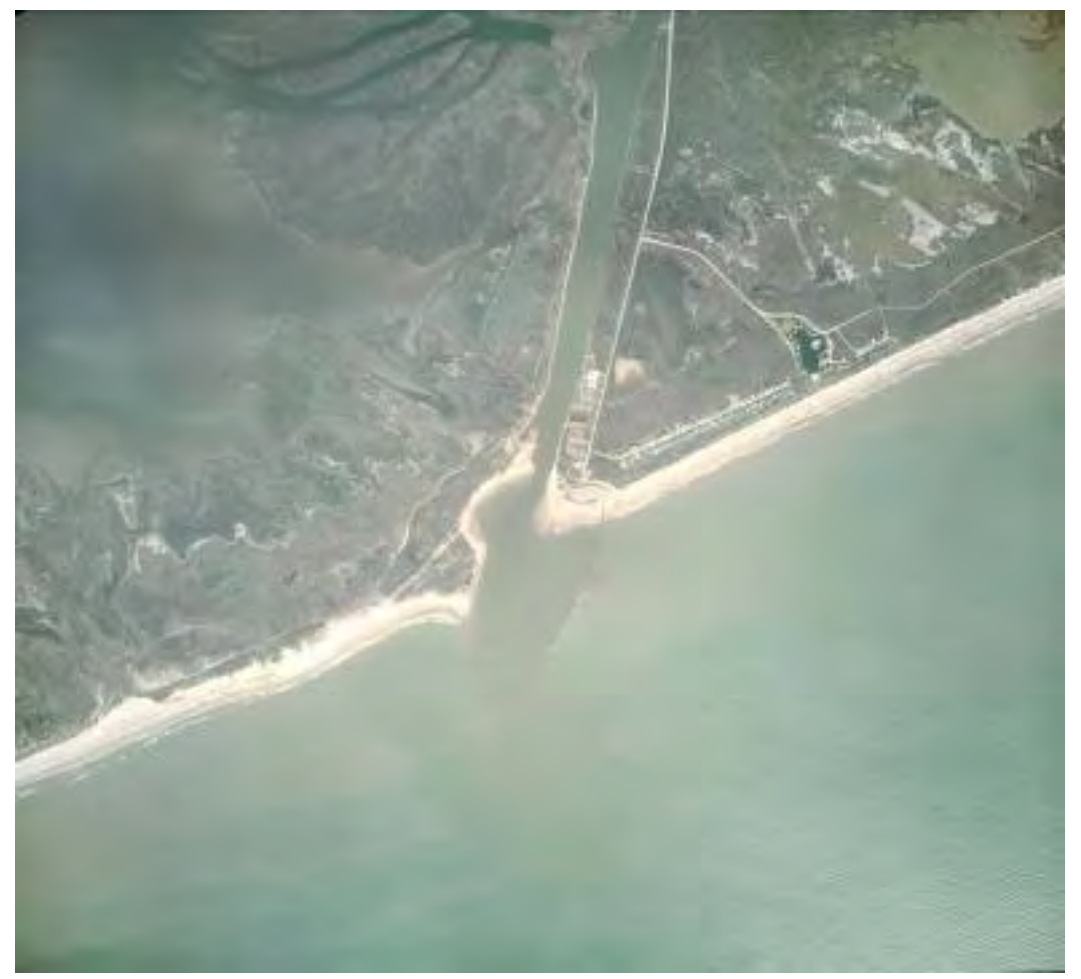

Figure C45. File 03-12-18-MOC-B.jpg, Mouth of Colorado River, 18 December 2003.

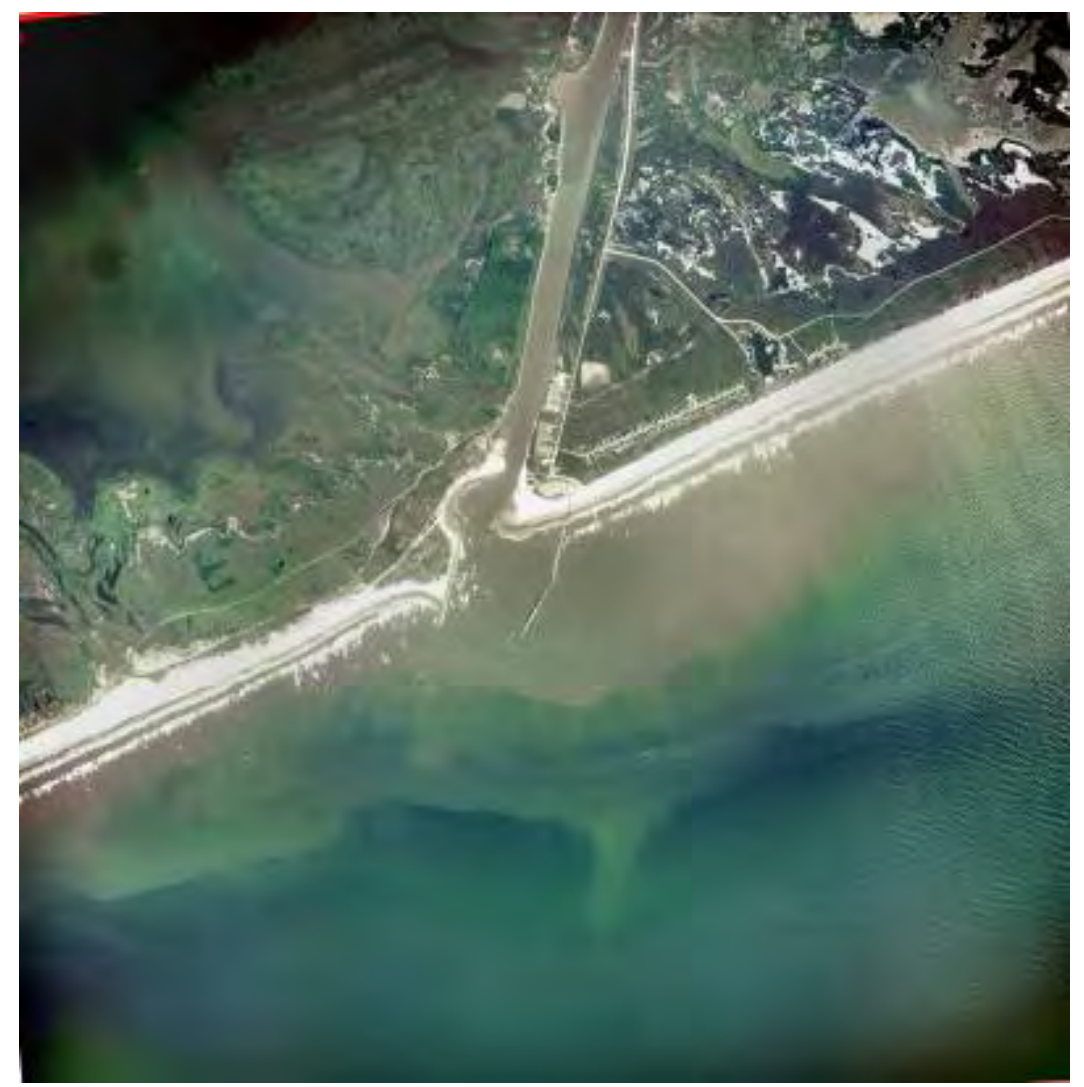

Figure C46. File 04-4-14-MOC.jpg, Mouth of Colorado River, 14 April 2004. 


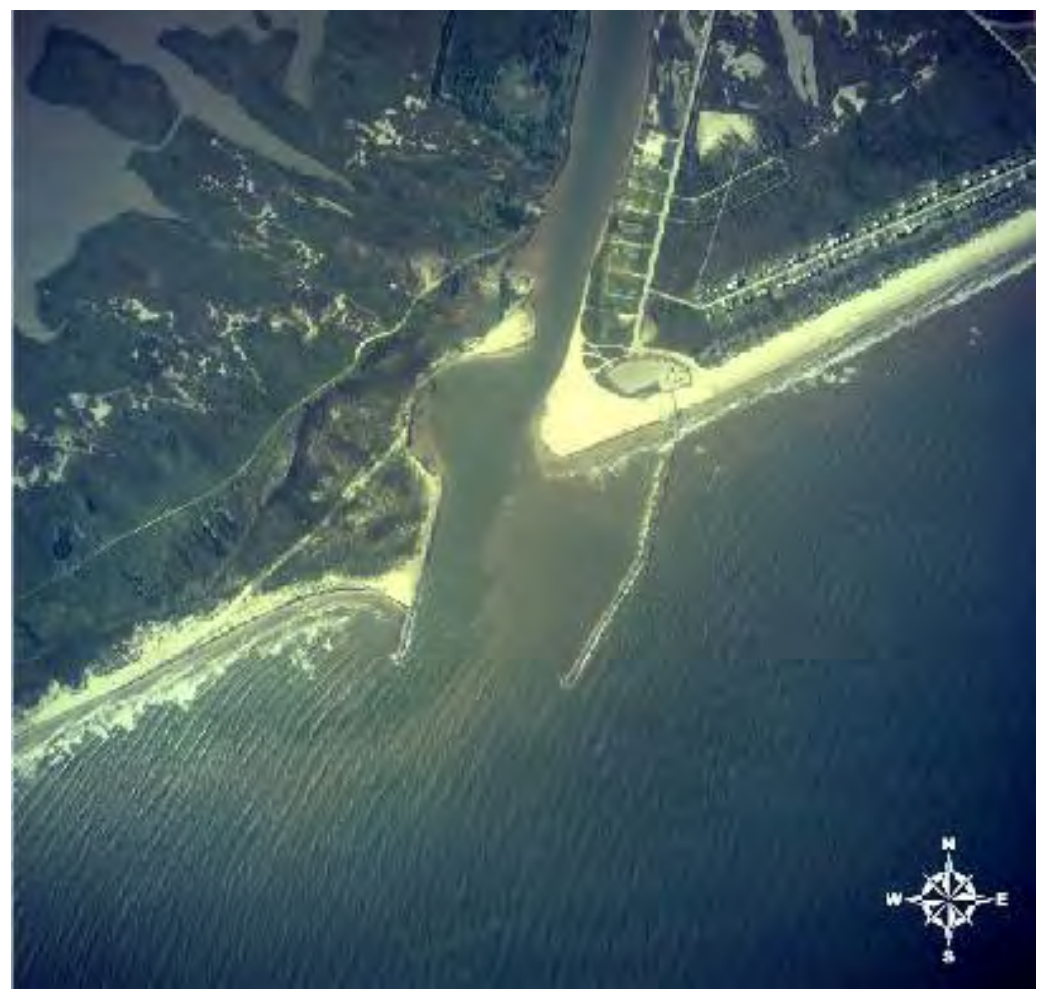

Figure C47. File 04-8-13-MOC-A.jpg, Mouth of Colorado River, 13 August 2004.

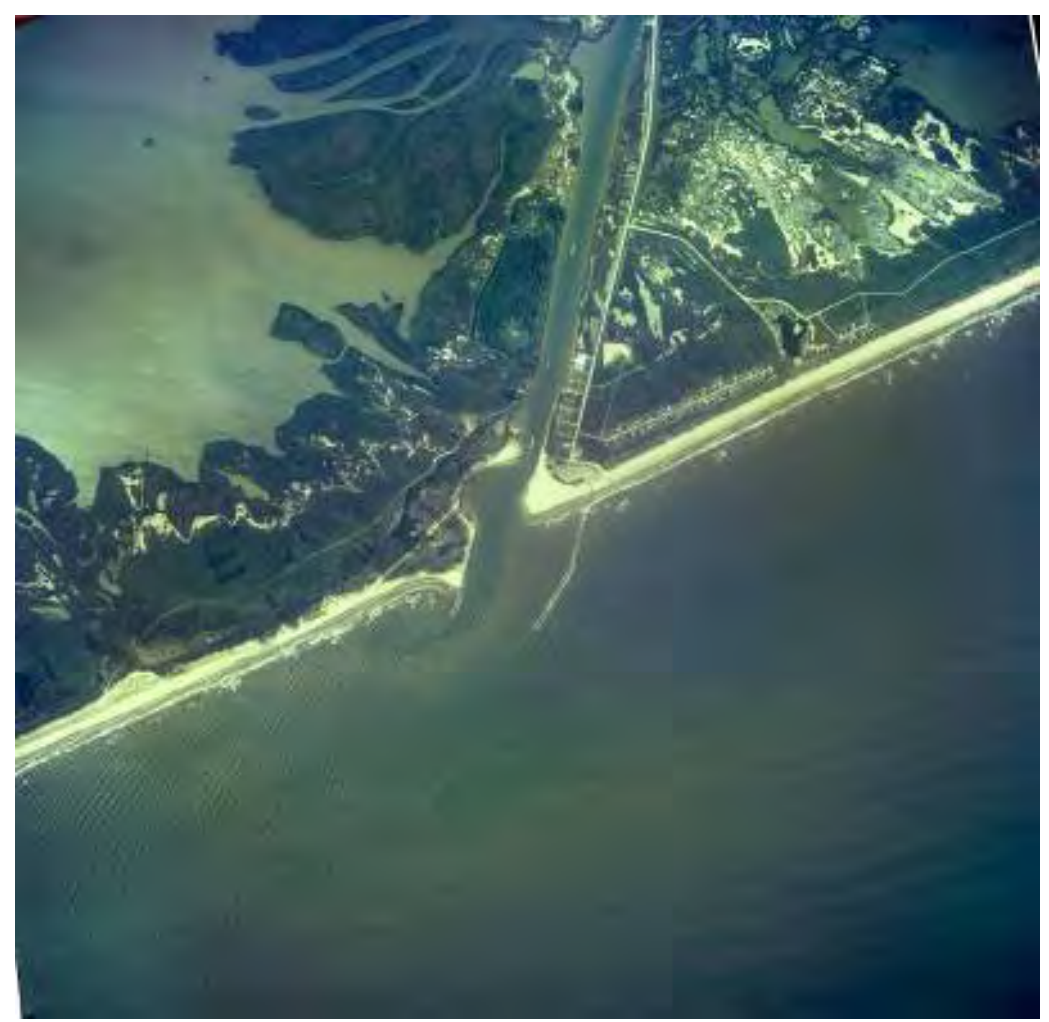

Figure C48. File 04-8-13-MOC-B.jpg, Mouth of Colorado River, 13 August 2004. 


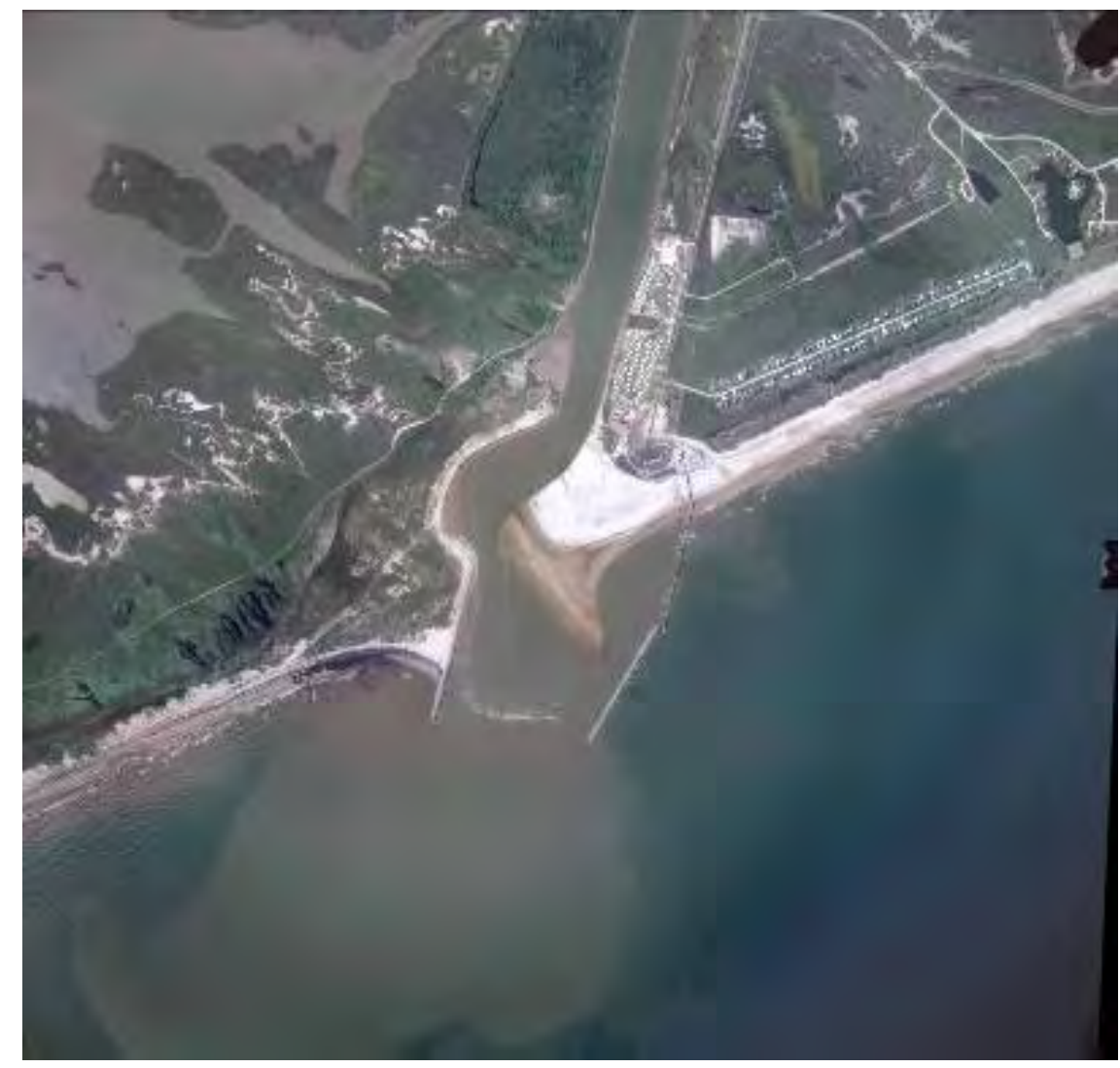

Figure C49. File 06-7-19-MOC.jpg, Mouth of Colorado River, 19 July 2006.

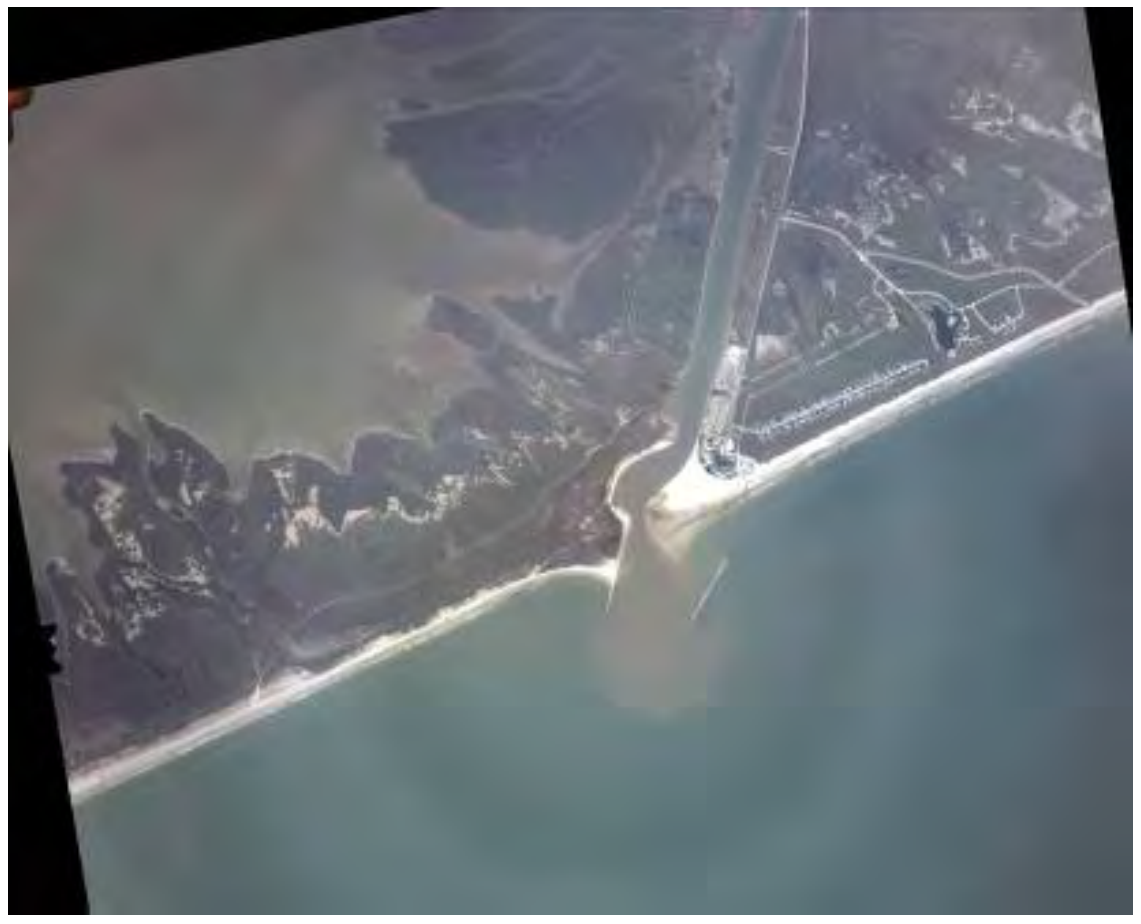

Figure C50. File 06-12-01-MOC-A.jpg, Mouth of Colorado River, 1 December 2006. 


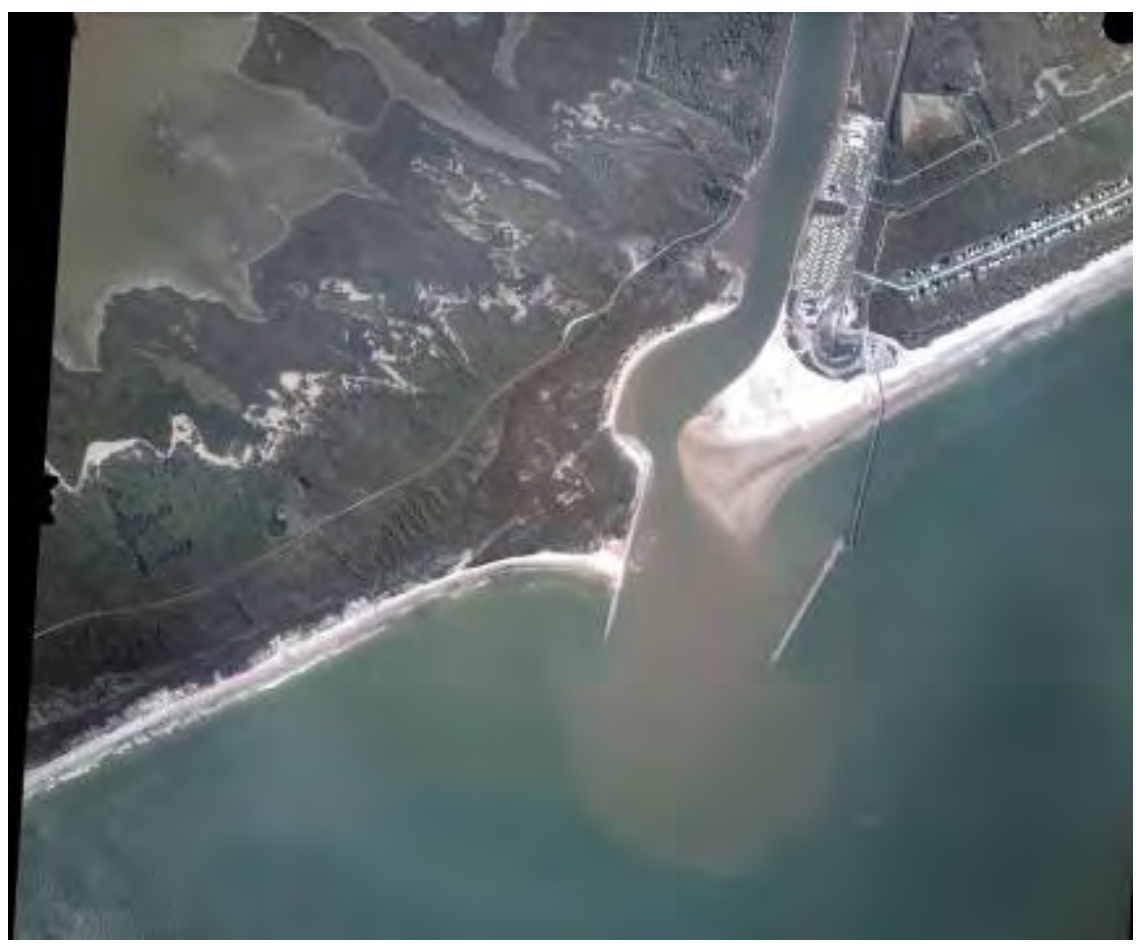

Figure C51. File06-12-01-MOC-B.jpg, Mouth of Colorado River, 1 December 2006.

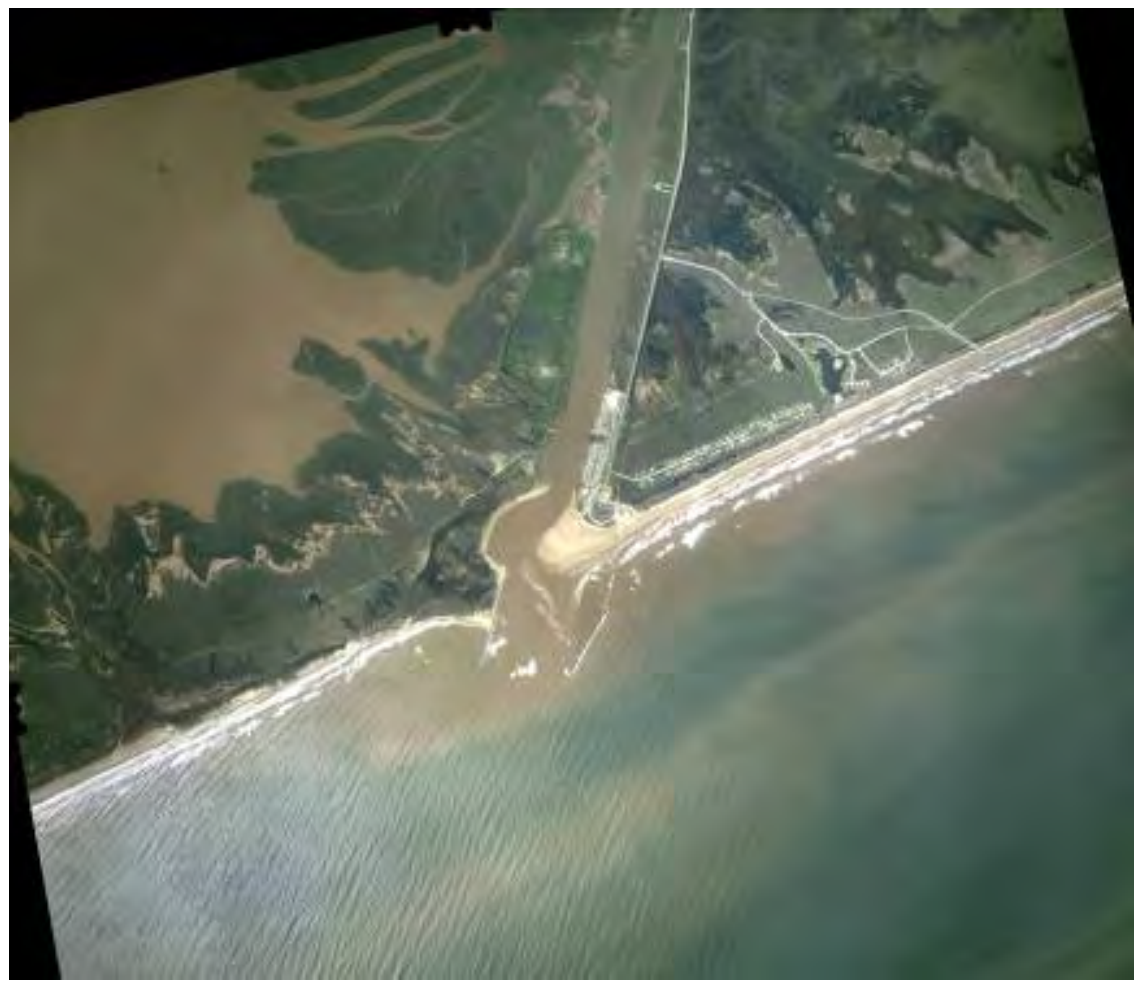

Figure C52. File 07-04-05-MOC-A.jpg, Mouth of Colorado River, 5 April 2007. 


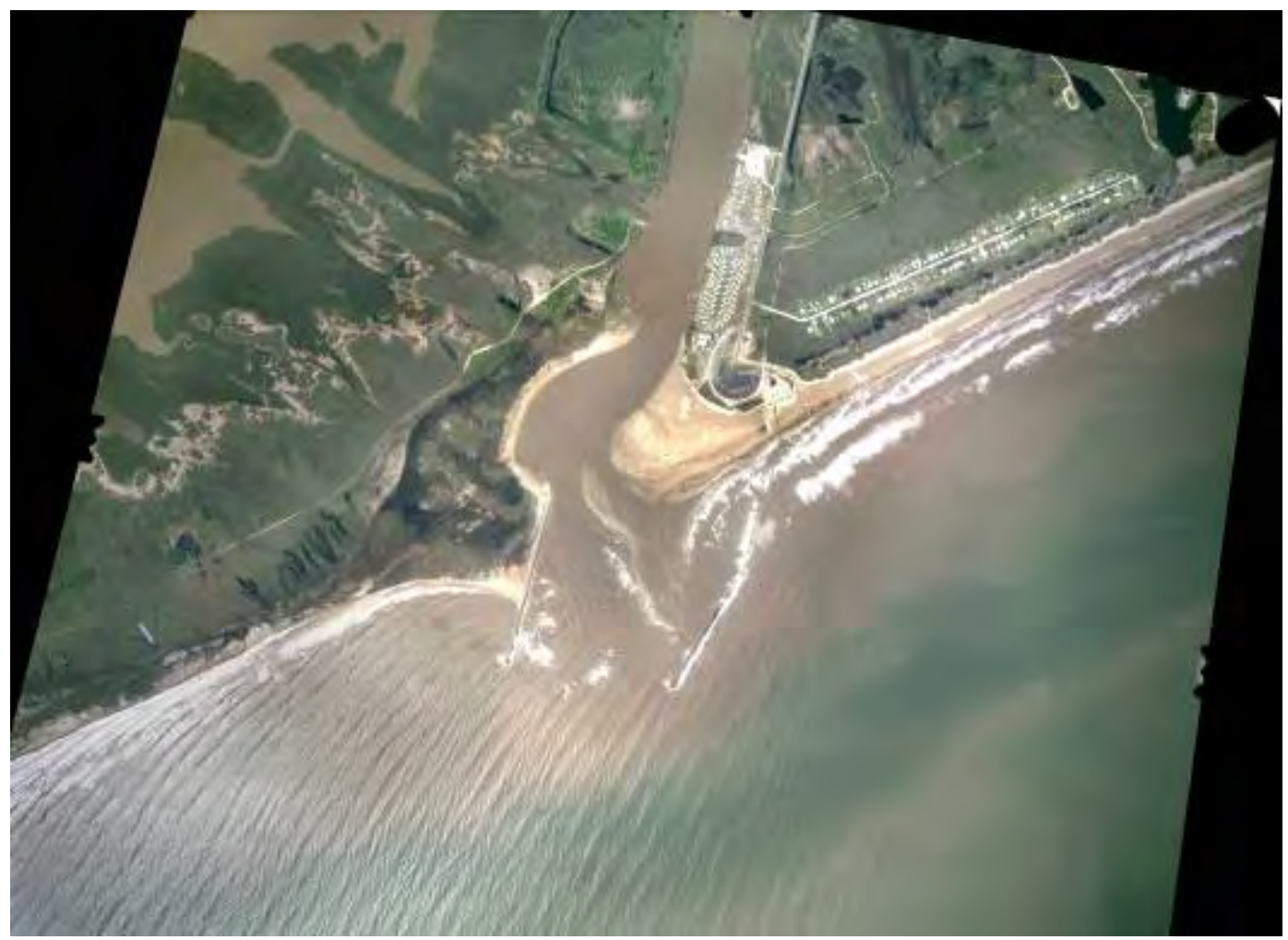

Figure C53. File 07-04-05-MOC-B.jpg, Mouth of Colorado River, 5 April 2007. 


\section{Appendix D: Subsurface Investigation}


- Geotechnical Engineering

- Construction Materials

ENGINEERING \& TESTING

- Solls • Asphalt • Concrete

August 27, 2007

HDR | Shiner Moseley and Associates, Inc.

555 N. Carancahua, Suite 1650

Corpus Christi, Texas 78487-0010

Attention: Daniel J. Heilman, P.E.

\section{SUBJECT: SUBSURFACE INVESTIGATION, LABORATORY TESTING PROGRAM AND GEOTECHNICAL RECOMMENDATIONS \\ FOR THE PROPOSED \\ NEW EAST JETTY \\ MOUTH OF THE COLORADO RIVER \\ MATAGORDA COUNTY, TEXAS \\ RETL Project Number: G207487}

Dear Mr. Heilman:

In accordance with our agreement, we have conducted a subsurface investigation and geotechnical evaluation for the above referenced project. The results of this investigation, together with our recommendations, are to be found in the accompanying report, 3-copies of which are being transmitted herewith.

Often, because of design and construction details that occur on a project, questions arise concerning soil conditions. Rock Engineering and Testing Laboratory, Inc. (RETL) would be pleased to continue its role as the Geotechnical Engineer during project implementation.

RETL also has great interest in providing materials testing and observation services during the construction phase of this project. If you will advise us of a convenient time to discuss these engineering services, we will be pleased to meet with you at that time.

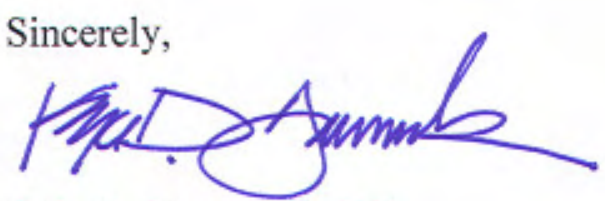

Kyle D. Hammock, P.E.

Vice President San Antonio

ROCK ENGINEERING \& TESTING LABORATORY, INC. www.rocktesting.com 


\section{SUBSURFACE INVESTIGATION, LABORATORY TESTING PROGRAM AND GEOTECHNICAL RECOMMENDATIONS \\ FOR THE PROPOSED \\ NEW EAST JETTY \\ MOUTH OF THE COLORADO RIVER \\ MATAGORDA COUNTY, TEXAS}

RETL JOB NUMBER: G207487

PREPARED FOR:

HDR | SHINER MOSELEY AND ASSOCIATES, INC.

555 N. CARANCAHUA, SUITE 1650

CORPUS CHRISTI, TEXAS 78487-0010

\section{AUGUST 27, 2007}

\section{PREPARED BY:}

ROCK ENGINEERING AND TESTING LABORATORY, INC.

4910 NEPTUNE

CORPUS CHRISTI, TEXAS 78405

PHONE: (361) 883-4555; FAX: (361) 883-4711

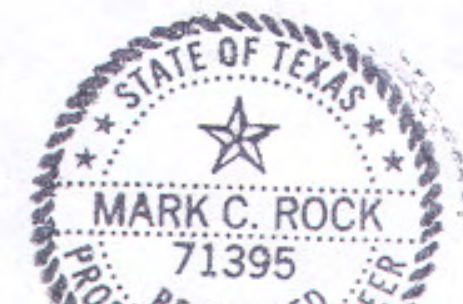

Mark C. Rock, P.E.

Vice President of Operations
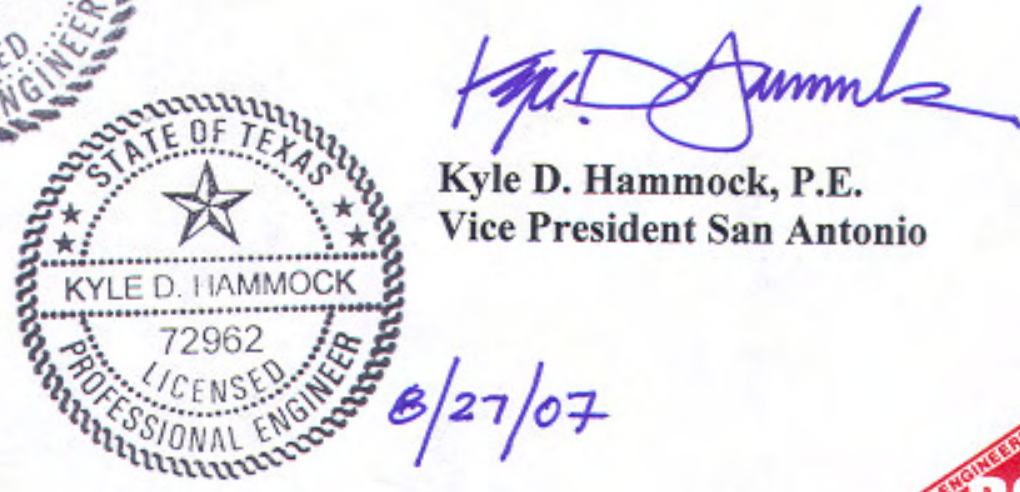

Kyle D. Hammock, P.E.

Vice President San Antonio 


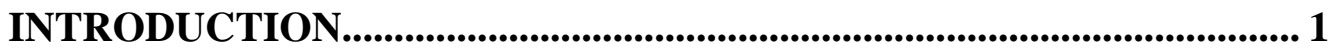

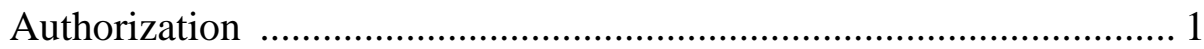

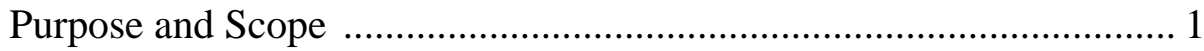

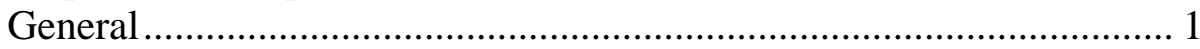

DESCRIPTION OF SITE .................................................................................... 2

Site Location and History ................................................................... 2

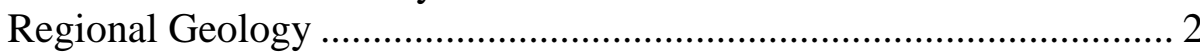

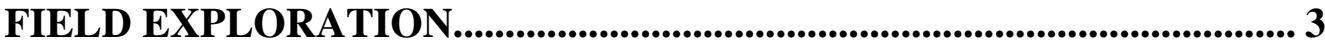

Scope ………............................................................................ 3

Drilling and Sampling Procedures ........................................................... 3

Field Tests and Measurements ............................................................ 4

LABORATORY TESTING PROGRAM ...................................................... 5

SUBSURFACE CONDITIONS ........................................................................ 5

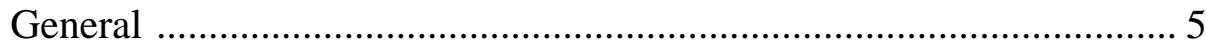

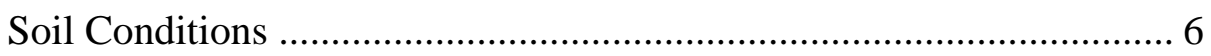

JETTY RECOMMENDATIONS.............................................................9

Project Description................................................................................. 9

Geotechnical Soil Design Parameters ................................................... 10

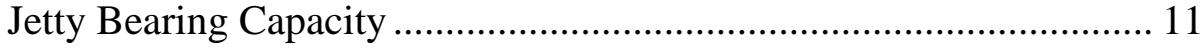

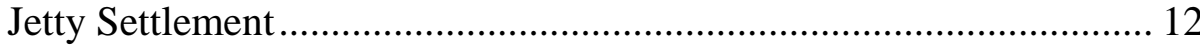

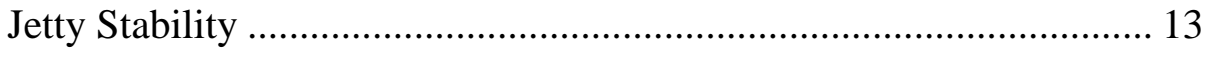

GENERAL COMMENTS ................................................................................. 14

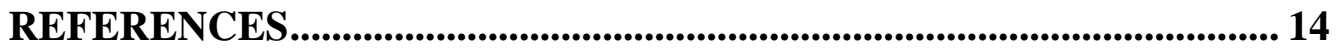

APPENDIX

Boring Location Plan

Boring Logs B-1 through B-7

Soil Stratigraphy Cross Section

Key to Soil Classifications

Consolidation Test Results

\section{ATTACHMENTS}

Proposed Jetty Section

Slope Stability for Drained Soil Condition

Slope Stability for Undrained Soil Condition 


\section{INTRODUCTION}

This report presents the results of a soils exploration, laboratory-testing program and geotechnical analysis for the proposed new East Jetty to be located at the Mouth of the Colorado River in Matagorda County, Texas.

\section{Authorization}

The work for this project was performed in accordance with RETL Proposal Number P061107A dated June 11, 2007. The proposal contained a scope of work and lump sum fee. The proposal was incorporated into an HDR Engineering, Inc. Geotechnical Subconsultant Agreement dated June 12, 2007.

\section{Purpose and Scope}

The purpose of this exploration was to identify and evaluate the soil conditions at the site and to provide geotechnical recommendations suitable for the proposed new East Jetty.

The scope of the exploration and analysis included the subsurface exploration, field and laboratory testing, engineering analysis and evaluation of the subsurface soils, developing geotechnical recommendations and preparation of this report.

The scope of services did not include an environmental assessment. Any statements in this report, or on the boring logs, regarding odors, colors, unusual or suspicious items or conditions are strictly for the information of the client.

\section{General}

The exploration and analysis of the subsurface conditions reported herein are considered sufficient in detail and scope to form a reasonable basis for design of the new jetty. The recommendations submitted for the proposed project are based on the available soil information and the preliminary design details provided by Daniel J. Heilman, P.E. of HDR | Shiner Moseley and Associates, Inc. (HDR). If the designers require additional soil parameters to complete the design of the proposed jetty, RETL will provide this information as a supplement to this report.

The Geotechnical Engineer states that the findings, recommendations, specifications or professional advice contained herein, have been presented after being prepared in a manner consistent with that level of care and skill ordinarily exercised by reputable members of the Geotechnical Engineer's profession practicing contemporaneously under similar conditions in the locality of the project. 
RETL operates in general accordance with "Standard Practice for Minimum Requirements for Agencies Engaged in the Testing and/or Inspection of Soil and Rock as Used in Engineering Design and Construction" (ASTM D 3740). No other representations are expressed or implied, and no warranty or guarantee is included or intended.

This report has been prepared for the exclusive use of HDR and the U.S. Army Corps of Engineers (USACE) for the specific purpose of the proposed new east jetty to be constructed at the mouth of the Colorado River.

\section{DESCRIPTION OF SITE}

\section{$\underline{\text { Site Location and History }}$}

The project site is located at the Mouth of the Colorado River (MCR), south of Bay City and Matagorda, in Matagorda County, Texas. The MCR was formerly the terminus of the Colorado River. However, the MCR is now the terminus of the Colorado River Navigation Channel (CRNC) after the diversion of the river into Matagorda Bay was completed in 1992. The MCR now only connects the Gulf Intracoastal Waterway and the CRNC to the Gulf of Mexico. The CRNC and MCR generally bisect Matagorda Peninsula.

The MCR has 2 existing jetties to protect the entrance. The east and west jetties are spaced approximately 1,350 feet apart at their gulfward ends. After the elimination of the river discharge into the Gulf of Mexico, excessive shoaling of the entrance began to occur.

\section{Regional Geology}

The Pleistocene Beaumont Clay underlies the coastal plain in the project area and controls the slope of the coast in the region. A thin layer of Holocene sand extends throughout the lower shoreface. The Beaumont Clay generally is a heterogeneous geologic formation containing relatively thick inter-bedded layers of clays, sands, silts and inter-bedded clay/sand soil strata. These soils were deposited as fluvio-deltaic sediments, augmented by strong run-off during interglacial periods.

The clay portion of the Beaumont Formation primarily consists of montmorillonite, illite, kaolinite and finely ground quartz. The clays have been pre-consolidated by the process of desiccation (over-consolidated clays). In addition, there have been numerous wetting and drying cycles over time, which have generated a network of randomly oriented joints. The joints are normally closely spaced and are sometimes slicken-sided; the latter denotes existing fracture and failure planes within the soil stratigraphy. 
Clays within the Beaumont Formation typically exhibit low permeability, high water-holding capacity, high compressibility, high to very high shrink-swell potential, high plasticity and low shear strength. The sands and silts of the Beaumont Formation vary in density and compactness from very loose to medium dense and very dense. These soils are composed of quartz, feldspars and relatively large particles of kaolinite, calcite and occasional hornblende.

\section{FIELD EXPLORATION}

\section{Scope}

The field exploration, to evaluate the engineering characteristics of the subsurface materials, included reconnaissance of the project site; drilling the test borings and recovering disturbed split spoon soil samples and relatively undisturbed Shelby tube samples. During the sample recovery operations the soils encountered were classified by an RETL engineer and recorded on boring logs in accordance with "Standard Guide for Field Logging of Subsurface Exploration of Soil and Rock" (ASTM D 5434).

Seven (7) borings were performed at the site at locations shown in the Boring Location Plan provided in the Appendix of this report. Borings B-3 and B-6 were drilled to a depth of 75 feet below the water level. Borings B-1 and B-2 were drilled to a depth of 45 feet below the water level. Borings B-4 and B-5 were drilled to depths of 40 feet and 35 feet below the water level, respectively. Boring B-7 was drilled on the land to a depth of 40 feet below the ground surface. RETL, with input from HDR and the USACE, planned the number, depth and location of the borings. All fieldwork was performed from July 24 to July 26, 2007.

\section{Drilling and Sampling Procedures}

The test borings were performed by Envirocore, Inc., a drilling sub-contractor to RETL, using a drilling rig equipped with a rotary head turning hollow stem augers to advance the boreholes. A floating spud barge operated by King Fisher Marine Services was utilized to access the boring locations. An RETL engineer coordinated the drilling and logged the borings.

Disturbed soil samples were obtained employing split-barrel sampling procedures in general accordance with the procedures for "Penetration Test and Split-Barrel Sampling of Soils" (ASTM D 1586) and undisturbed samples were obtained using thin-wall sampling procedures in accordance with "Thin Walled Tube Sampling of Soils" (ASTM 1587). The samples obtained by this procedure were extruded by a hydraulic ram and classified in the field.

All of the samples were placed in plastic bags, marked according to boring number, depth and any other pertinent field data, stored in special containers and delivered to the laboratory for testing. 


\section{Field Tests and Measurements}

Penetration Tests - During the sampling procedures standard penetration tests (SPT) were performed to obtain the standard penetration value of the soil. The standard penetration value (N) is defined as the number of blows of a 140-pound hammer, falling 30-inches, required to advance the split-barrel sampler 1 foot into the soil. The sampler is lowered to the bottom of the previously cleaned drill hole and advanced by blows from the hammer.

The number of blows is recorded for each of three successive 6-inch penetrations. The " $N$ " value is obtained by adding the second and third 6-inch increment number of blows. The results of standard penetration tests indicate the relative density of cohesionless soils and comparative consistency of cohesive soils, thereby providing a basis for estimating the relative strength and compressibility of the soil profile components.

Sampling Intervals - Soil samples were obtained using split-barrel and thin-wall sampling procedures as discussed previously. Soil sampling was performed at $21 / 2$-foot intervals to a depth of 20 feet below the water surface and at 5 -foot intervals thereafter. These sampling intervals are considered to be sufficient in quantity to define the near surface and deeper subsurface soil conditions, while optimizing the productivity of the drilling operations. The geotechnical engineering community in the local area has used the $2 \frac{1}{2} 2$ foot transitioning to 5 -foot sampling interval program for many years.

Water Depth Measurements and Boring Coordinates - The water depths provided are approximate depths obtained by RETL using a tape measure at the time of the drilling. The water surface elevation data was provided to RETL by HDR. The coordinates of the borings were obtained by RETL using a hand held GPS device. The data is provided in Table 1.

\begin{tabular}{|c|c|c|c|c|}
\hline $\begin{array}{c}\text { BORING } \\
\text { NO. } \\
\end{array}$ & $\begin{array}{c}\text { WATER SURFACE } \\
\text { EL. (NAVD'88) } \\
\end{array}$ & $\begin{array}{l}\text { WATER DEPTH, } \\
\text { FT. } \\
\end{array}$ & LATITUDE & LONGITUDE \\
\hline B-1 & +1.0 & 8.5 & N 28 $35^{\prime} 24.9^{\prime \prime}$ & W 95 58' 58.3” \\
\hline B-2 & +1.0 & 12.5 & N 28 $35^{\prime} 25.2^{\prime \prime}$ & W 95 59'03.9” \\
\hline B-3 & +0.5 & 6 & $\mathrm{~N} 28^{\circ} 35^{\prime} 27.9^{\prime \prime}$ & W 95 58' 57.4” \\
\hline B-4 & -0.5 & 6 & N 28 $35^{\prime} 30.5^{\prime \prime}$ & W 95 58' 56.3” \\
\hline B-5 & +1.0 & 10.5 & $\mathrm{~N} 28^{\circ} 35^{\prime} 34.9^{\prime \prime}$ & W 95 58' 55.0” \\
\hline B-6 & +1.0 & 6 & $\mathrm{~N} 28^{\circ} 35^{\prime} 39.1$ " & W $95^{\circ} 58^{\prime} 54.6^{\prime \prime}$ \\
\hline B-7 & On Land & On Land & $\mathrm{N} 28^{\circ} 35^{\prime} 44.8^{\prime \prime}$ & W $95^{\circ} 58^{\prime} 50.2^{\prime \prime}$ \\
\hline
\end{tabular}




\section{LABORATORY TESTING PROGRAM}

In addition to the field investigation, a laboratory-testing program was conducted to determine additional pertinent engineering characteristics of the subsurface materials necessary in analyzing the behavior of the proposed jetty system.

The laboratory-testing program included supplementary visual classification (ASTM D 2487) and water content tests (ASTM D 2216) on all samples. In addition, selected samples were subjected to Atterberg limits tests (ASTM D 4318), percent material finer than the \#200 sieve (ASTM D 1140) and one-dimensional consolidation tests (ASTM D 2435).

The shear strengths of cohesive soil samples were evaluated from unconfined compressive strength tests (ASTM D 2166). Estimated soil strengths were obtained using a hand penetrometer.

All phases of the laboratory-testing program were conducted in general accordance with applicable ASTM Specifications. The results of these tests are to be found on the accompanying boring logs provided in the Appendix.

\section{SUBSURFACE CONDITIONS}

\section{$\underline{\text { General }}$}

The types of subsurface materials encountered in the test borings have been visually classified and are described in detail on the boring logs. The results of the field penetration tests, strength tests, water level measurements and other laboratory tests are presented on the boring logs in numerical form. Representative samples of the soils were placed in polyethylene bags and are now stored in the laboratory for further analysis, if desired. Unless notified to the contrary, all samples will be disposed of three months after issuance of this report.

The stratification of the soil, as shown on the boring logs, represents the soil conditions at the actual boring locations. Variations may occur between, or beyond, the boring locations. Lines of demarcation represent the approximate boundary between different soil types, but the transition may be gradual, or not clearly defined.

It should be noted that, whereas the test borings were drilled and sampled by experienced drillers, it is sometimes difficult to record changes in stratification within narrow limits. In the absence of foreign substances, it is also difficult to distinguish between discolored soils and clean soil fill. 


\section{$\underline{\text { Soil Conditions }}$}

Previous geotechnical information from the site USACE (1977) indicated medium dense sands extending to elevation -15 feet NGVD'29, very soft clays from elevation -15 feet to -25 feet NGVD'29, stiff clays from elevation -25 feet to -35 feet NGVD'29, and dense sands from elevation -35 feet to -45 feet NGVD'29. Geotechnical data below elevation -45 feet NGVD'29 were not available. For approximate correlations between the various elevation datums referenced in this report, refer to Table 2. These correlations were provided to RETL by HDR.

\begin{tabular}{||c|c||}
\hline \multicolumn{2}{||c||}{ TABLE 2: DATUM CORRELATIONS } \\
\hline \hline Datum & $\begin{array}{c}\text { Approximate Elevation with } \\
\text { Respect to NAVD'88, ft }\end{array}$ \\
\hline \hline MHHW & +1.71 \\
\hline MSL & +1.09 \\
\hline MLLW & +0.38 \\
\hline NAVD'88 & 0.00 \\
\hline NGVD'29 & -0.21 \\
\hline $\begin{array}{c}\text { USACE } \\
\text { NAVD'88 }\end{array}$ & -1.48 \\
\hline
\end{tabular}

The generalized soil conditions encountered at the site during this subsurface exploration consist of an upper stratum of loose to medium dense sandy soils extending to approximate elevation -32 feet NAVD'88. The upper sandy soils are underlain by intermediate strata of stiff to very stiff clayey soils extending to approximate elevation -47 feet NAVD'88 and medium dense to very dense sandy soils extending to approximate elevation -67 feet NAVD'88. The intermediate depth clayey and sandy soils are underlain by a deeper stratum of firm to stiff clayey soils extending to approximate elevation -75 feet NAVD'88. The soil conditions encountered in boring B-2, located at the end of the existing west jetty, were not included in the discussion above.

The upper sandy soils are classified as silty sands and poorly graded sands, contain minimal fines and are non-plastic. The old navigation channel appears to have been shoaled in with these sands. The intermediate depth clayey soils are classified as fat clays, lean clays and clayey sands, and are low to high in plasticity. The intermediate depth sandy soils are classified as poorly graded sands, contain minimal fines and are non-plastic. The deep clayey soils are classified as fat clays and are very high in plasticity. 
The soil conditions encountered at the boring locations have been summarized and soil properties including plasticity, strength, grain size and classification are provided in Tables 3 through 7. The following terms and acronyms are used in these tables:

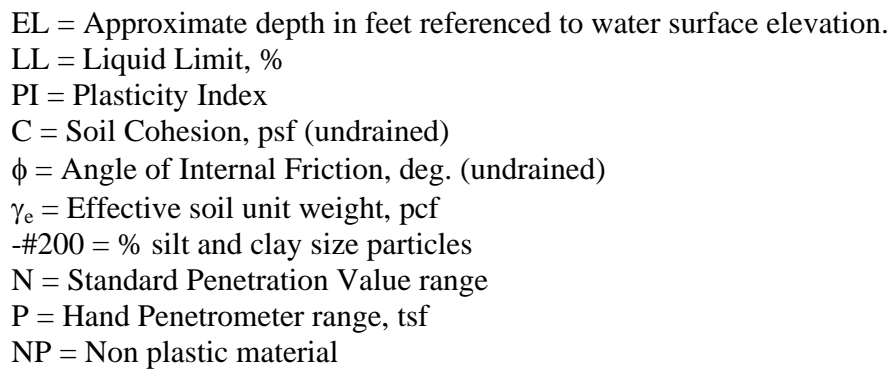

TABLE 3: SOIL PROFILE FOR BORINGS B-1 AND B-3

\begin{tabular}{||c|c|c|c|c|c|c|c|c||}
\hline \hline EL & Description & LL & PI & $\mathbf{C}$ & $\boldsymbol{\phi}$ & $\gamma_{\mathbf{e}}$ & $-\# 200$ & $\mathbf{N}$ or P \\
\hline \hline-8 to -32 & $\begin{array}{c}\text { Silty SAND/ } \\
\text { Poorly Graded SAND }\end{array}$ & $\mathrm{NP}$ & $\mathrm{NP}$ & 0 & 29 & 55 & $4-16$ & $\mathrm{~N}=4-21$ \\
\hline-32 to -42 & Fat CLAY & $51-59$ & $33-38$ & 1500 & 0 & 60 & $72-78$ & $\mathrm{P}=2.5$ \\
\hline-42 to -47 & Clayey SAND & 33 & 17 & 1500 & 0 & 60 & $31-40$ & $\mathrm{P}=1.75-2.5$ \\
\hline-47 to -67 & Poorly Graded SAND & $\mathrm{NP}$ & $\mathrm{NP}$ & 0 & 35 & 60 & $5-7$ & $\mathrm{~N}=7-72$ \\
\hline-67 to -75 & Fat CLAY & 69 & 42 & 1000 & 0 & 55 & $88-90$ & $\mathrm{~N}=4-7$ \\
\hline \hline
\end{tabular}

TABLE 4: SOIL PROFILE FOR BORING B-2

\begin{tabular}{||c|c|c|c|c|c|c|c|c||}
\hline \hline EL & Description & LL & PI & $\mathbf{C}$ & $\phi$ & $\gamma_{\mathbf{e}}$ & $-\# 200$ & $\mathbf{N}$ or P \\
\hline \hline-12 to -16 & Silty SAND & NP & NP & 0 & 28 & 55 & 13 & $\mathrm{~N}=8$ \\
\hline-16 to -27 & Clayey SAND & 47 & 31 & 300 & 0 & 55 & $36-45$ & $\mathrm{~N}=2-3$ \\
\hline-27 to -32 & Sandy Fat CLAY & --- & --- & 200 & 0 & 55 & --- & $\mathrm{N}=2$ \\
\hline-32 to -42 & Sandy Lean CLAY & $38-47$ & $23-31$ & 2000 & 0 & 60 & $59-68$ & $\mathrm{P}=4.25$ \\
\hline-42 to -45 & Poorly Graded SAND & NP & NP & 0 & 30 & 55 & 7 & $\mathrm{~N}=7$ \\
\hline \hline
\end{tabular}


TABLE 5: SOIL PROFILE FOR BORINGS B-4 AND B-5

\begin{tabular}{||c|c|c|c|c|c|c|c|c||}
\hline \hline EL & Description & LL & PI & $\mathbf{C}$ & $\boldsymbol{\phi}$ & $\gamma_{\mathbf{e}}$ & $-\# \mathbf{2 0 0}$ & $\mathbf{N}$ or P \\
\hline \hline-8 to -27 & $\begin{array}{c}\text { Silty SAND/ } \\
\text { Poorly Graded SAND }\end{array}$ & NP & NP & 0 & 29 & 55 & $3-40$ & $\mathrm{~N}=3-22$ \\
\hline-27 to -32 & $\begin{array}{c}\text { Silty SAND/ } \\
\text { Clayey SAND }\end{array}$ & $19-26$ & $3-13$ & 200 & 0 & 55 & $32-34$ & $\mathrm{~N}=2$ \\
\hline-32 to -40 & Clayey SAND & $36-40$ & $22-26$ & 2000 & 0 & 60 & $31-46$ & $\mathrm{P}=4.0-4.25$ \\
\hline \hline
\end{tabular}

TABLE 6: SOIL PROFILE FOR BORING B-6

\begin{tabular}{||c|c|c|c|c|c|c|c|c||}
\hline \hline EL & Description & LL & PI & $\mathbf{C}$ & $\phi$ & $\gamma_{\mathbf{e}}$ & $-\# 200$ & $\mathbf{N}$ or P \\
\hline \hline-6 to -15 & $\begin{array}{c}\text { Silty SAND/ } \\
\text { Poorly Graded SAND }\end{array}$ & NP & NP & 0 & 28 & 55 & $1-33$ & $\mathrm{~N}=4-22$ \\
\hline-15 to -27 & $\begin{array}{c}\text { Silty SAND/ } \\
\text { Silty CLAY }\end{array}$ & $18-19$ & $3-5$ & 200 & 0 & 55 & $42-64$ & $\mathrm{~N}=\mathrm{WH}-1$ \\
\hline-27 to -32 & Sandy Lean CLAY & 38 & 24 & 300 & 0 & 55 & 59 & $\mathrm{~N}=3$ \\
\hline-32 to -42 & Fat CLAY & 57 & 36 & 2000 & 0 & 60 & $73-78$ & $\mathrm{P}=1.75-4.25$ \\
\hline-42 to -47 & Clayey SAND & --- & --- & 0 & 32 & 60 & 39 & $\mathrm{~N}=13$ \\
\hline-47 to -67 & Poorly Graded SAND & NP & NP & 0 & 35 & 60 & $5-6$ & $\mathrm{~N}=6-29$ \\
\hline-67 to -75 & Fat CLAY & 70 & 42 & 1000 & 0 & 60 & $95-96$ & $\mathrm{~N}=5-8$ \\
\hline \hline
\end{tabular}

TABLE 7: SOIL PROFILE FOR BORING B-7

\begin{tabular}{||c|c|c|c|c|c|c|c|c||}
\hline \hline EL & Description & LL & PI & $\mathbf{C}$ & $\boldsymbol{\phi}$ & $\gamma_{\mathbf{e}}$ & $-\# \mathbf{2 0 0}$ & $\mathbf{N}$ or P \\
\hline \hline 0 to -32 & $\begin{array}{c}\text { Silty SAND/ } \\
\text { Poorly Graded SAND }\end{array}$ & NP & NP & 0 & 30 & 55 & $1-18$ & $\mathrm{~N}=4-42$ \\
\hline-32 to -40 & Clayey SAND & 42 & 27 & 2500 & 0 & 60 & 35 & $\mathrm{P}=4.25-4.5$ \\
\hline \hline
\end{tabular}




\section{JETTY RECOMMENDATIONS}

\section{Project Description}

It is understood that the proposed project consists of the construction of an approximate 2100foot long jetty designated as the "new east jetty" that will connect to the existing training dike on the north end and will extend out into the Gulf of Mexico to a similar distance as the existing west jetty. The new east jetty will be located approximately 500 -feet from the west jetty. A majority of the new jetty will be located over the previous navigation channel, which was originally dredged and periodically maintained to an approximate elevation of -18 feet MLT. The channel has subsequently shoaled in and, in its present state, hinders navigation to and from the Gulf of Mexico.

As shown in the project concept drawings prepared by HDR dated November 17, 2007, the proposed landside portion of the new jetty will be founded near elevation -3 feet NAVD'88 with a bottom width of approximately 90 feet. The top of the jetty (subsequent to total settlement) is intended to be at +8 feet NAVD' 88 with a crown width of about 16 feet. The waterside portion of the new jetty is proposed to be founded near elevation -9 feet NAVD'88 with a bottom width of approximately 125 feet. The top of the jetty (subsequent to total settlement) is intended to be at +6.4 feet NAVD' 88 with a crown width of about 16 feet.

HDR also provided historical geotechnical information including Turner, Collie \& Braden, Inc., and DMJM-Harris (2002) and USACE (1977). This information was utilized to perform preliminary jetty bearing capacity, settlement and stability analyses as provided in RETL (2007).

\section{Geotechnical Soil Design Parameters}

RETL investigated the soils on the jetty landside and jetty waterside and has developed average geotechnical soil design parameters based on the results of the field and laboratory testing. RETL has grouped the site into three (3) predominant soil stratigraphy conditions designated as Zones A, B and C. The three zones of soils stratigraphy are summarized in Tables 8 through 10. 


\begin{tabular}{||c|c|c|c|c|c|c||}
\hline \multicolumn{6}{|c||}{ TABLE 8: GENERALIZED SOIL STRATIGRAPHY FOR } \\
WATERSIDE ZONE A (BORINGS B-1, B-3, B-4, AND B-5) \\
\hline \hline $\begin{array}{c}\text { Approximate } \\
\text { Elevation, ft } \\
\text { (NAVD'88) }\end{array}$ & Description & C & $\boldsymbol{\phi}$ & C' & $\boldsymbol{\phi}^{\prime}$ & $\gamma_{\mathrm{e}}$ \\
\hline-8 to -32 & Sand & 0 & 29 & 0 & 30 & 55 \\
\hline-32 to -47 & Clay & 1500 & 0 & 520 & 25 & 60 \\
\hline-47 to -67 & Sand & 0 & 35 & 0 & 35 & 60 \\
\hline-67 to -75 & Clay & 1000 & 0 & 400 & 20 & 55 \\
\hline
\end{tabular}

\begin{tabular}{||c|c|c|c|c|c|c||}
\hline \multicolumn{6}{|c|}{ TABLE 9: GENERALIZED SOIL STRATIGRAPHY FOR } \\
LANDSIDE ZONE B (BORING B-6) \\
\hline $\begin{array}{c}\text { Approximate } \\
\text { Elevation, ft } \\
\text { (NAVD'88) }\end{array}$ & Description & C & $\phi$ & C' & $\phi ’$ & $\gamma_{\mathbf{e}}$ \\
\hline-6 to -15 & Sand & 0 & 28 & 0 & 30 & 55 \\
\hline-15 to -32 & Clay & 250 & 0 & 200 & 17.5 & 50 \\
\hline-32 to -47 & Clay & 2000 & 0 & 520 & 25 & 60 \\
\hline-47 to -67 & Sand & 0 & 35 & 0 & 35 & 60 \\
\hline-67 to -75 & Clay & 1000 & 0 & 400 & 20 & 55 \\
\hline
\end{tabular}

\begin{tabular}{||c|c|c|c|c|c|c||}
\hline \multicolumn{6}{||c||}{ TABLE 10: GENERALIZED SOIL STRATIGRAPHY FOR } \\
LANDSIDE ZONE C (BORING B-7) \\
\hline \hline $\begin{array}{c}\text { Approximate } \\
\text { Elevation, ft } \\
\text { (NAVD'88) }\end{array}$ & Description & $\mathbf{C}$ & $\boldsymbol{\phi}$ & $\mathbf{C}^{\prime}$ & $\boldsymbol{\phi}^{\prime}$ & $\gamma_{\mathbf{e}}$ \\
\hline 0 to -32 & Sand & 0 & 30 & 0 & 30 & 55 \\
\hline-32 to -40 & Clay & 2500 & 0 & 520 & 25 & 60 \\
\hline
\end{tabular}




\section{Jetty Bearing Capacity}

The pressure that a foundation unit can impose onto the supporting earth mass without causing shear failure is bearing capacity. The ultimate bearing capacity is the pressure at which failure occurs. The ultimate soil-bearing capacity is related to the properties of the soil to the depth that will have significant effect on the performance of the structure, and the size, depth and shape of the foundation.

The new jetty system was analyzed as a shallow strip footing type foundation. The estimated ground contact pressure and the foundation width were based on the crown section of the jetty and an average material unit weight of 165 pcf. The bearing capacity of the soils for the various soil stratigraphy zones along the waterside and landside jetty alignments were analyzed using Meyerhof's bearing capacity equation as presented in Bowles (1996). This equation utilizes values of soil cohesion and internal friction, foundation size, bearing soil weight, soil surcharge, embedment depth and dimensionless bearing capacity factors. The results of the analysis are summarized in Table 11.

\begin{tabular}{||c|c|c|c||}
\hline \multicolumn{5}{|c|}{ TABLE 11: JETTY BEARING CAPACITY } \\
\hline \hline Zone & $\begin{array}{c}\text { Max. Estimated Ground } \\
\text { Contact Pressure, psf }\end{array}$ & $\begin{array}{c}\text { Ultimate Soil Bearing } \\
\text { Capacity, psf }\end{array}$ & $\begin{array}{c}\text { Estimated } \\
\text { Safety Factor }\end{array}$ \\
\hline \hline $\begin{array}{c}\mathbf{A} \\
\text { (Waterside) }\end{array}$ & 2,000 & 6,700 & 3.4 \\
\hline $\begin{array}{c}\mathbf{B} \\
\text { (Landside) }\end{array}$ & 1,600 & 4,800 & 3.0 \\
\hline $\begin{array}{c}\mathbf{C} \\
\text { (Landside) }\end{array}$ & 1,600 & 7,700 & 4.8 \\
\hline \hline
\end{tabular}

The results of the analyses indicate that the upper stratum of loose to medium dense sand and deeper strata of clay and sand provide adequate soil bearing capacity for the new jetty.

\section{$\underline{\text { Jetty Settlement }}$}

Stresses on the soils below the jetty are dependent on the jetty width and the magnitude of pressure or stress imposed on the soil. Based on data developed by Boussinesq as presented in Bowles (1996), the stress dissipates approximately 25 percent at a depth equal to half the width, dissipates approximately 50 percent at a depth equal to the width and dissipates approximately 75 percent at a depth equal to twice the width. The stress on the various soil strata along with the thickness of the strata and engineering properties of the soils are used to calculate settlement. 
The immediate, short-term and long-term jetty settlements were evaluated for the various soil stratigraphy zones along the waterside and landside jetty alignments. Settlement contributions from the upper sand stratum were relatively small in magnitude. In addition, the intermediate depth clays appear to be "over consolidated" with a pre-consolidation pressure of at least 1 tsf.

The immediate settlement is an elastic deformation, which occurs rapidly during the application of the load. The immediate elastic settlements at the site will likely be relatively small in magnitude due to the presence of the upper sand stratum.

Short-term settlements (assumed to occur within 1-year after construction) were estimated as being approximately $50 \%$ of the long-term calculated settlement based on the coefficient of consolidation data obtained from the consolidation test results.

The long term or consolidation settlement occurs primarily in clay soils due to a decrease in the voids as water is forced out of the soil over time. Since the intermediate depth soft to stiff clays have sand strata above and below, the drainage path is half of the thickness of the clay layer, which will result in shorter consolidation times.

The total jetty settlement should be taken as the sum of the immediate settlement and the longterm settlement. The results of the analysis are as follows:

\begin{tabular}{||c|c|c|c||}
\hline \multicolumn{5}{|c|}{ TABLE 12: JETTY SETTLEMENT } \\
\hline \hline Zone & $\begin{array}{c}\text { Immediate } \\
\text { Settlement, in. }\end{array}$ & $\begin{array}{c}\text { Short Term } \\
\text { Settlement, in. }\end{array}$ & $\begin{array}{c}\text { Long Term } \\
\text { Settlement, in. }\end{array}$ \\
\hline \hline $\begin{array}{c}\text { A } \\
\text { (Waterside) }\end{array}$ & 1 to 2 & 3 to 5 & 5 to 9 \\
\hline $\begin{array}{c}\text { B } \\
\text { (Landside) }\end{array}$ & 1 to 2 & 6 to 9 & 12 to 18 \\
\hline $\begin{array}{c}\text { C } \\
\text { (Landside) }\end{array}$ & 1 to 2 & 1 to 2 & 2 to 3 \\
\hline
\end{tabular}

The long term or consolidation settlement has the largest magnitude in Zone B. This zone has the thickest layer of soft clay, which is below the upper sand stratum and above the intermediate depth stiff clays. The total settlement in Zone B will be expected to be 95 percent complete in approximately 6 years.

\section{Jetty Stability}

Slope stability calculations were performed using the average soils properties and software that utilizes the Bishop Modified Method (Bishop, 1955) and Janbu's Simplified Method (Janbu et al., 1956). Visual observation of the three predominate soil conditions encountered, Zones A, B and $\mathrm{C}$, indicate the most likely zone to pose problems associated with slope stability is Zone $\mathrm{B}$ (Borings B-2 and B-6). Boring B-2, which is located near the end of the existing west jetty, is of no consequence to this phase of the project due to distance away from the proposed new east jetty location. 
Boring B-6 was performed approximately 100 feet west of the centerline of the proposed east jetty at approximate Station $8+50$. The proposed jetty section at this location is depicted on Sheet E2, Detail 2 in the conceptual drawings provided by HDR as included as Attachment 1. The proposed jetty section was input along with the soil stratigraphy, soil parameters and proposed flotation channel at this location and the slope stability was analyzed. It should be noted that, within the model, the proposed flotation channel was assumed to be dredged to a depth of -9 feet MLT and that the top of the flotation channel slope would begin at a distance of 10 feet from the jetty toe.

Our analyses indicate that, given the scenario described above and the soils encountered at the boring locations, the minimum slope stability safety factor is near 1.33 , or greater, which is considered to be an acceptable safety factor for projects similar to the type being constructed at this site. It should be noted that the analysis that resulted in the safety factor provided is a surficial failure on the slope of the upper sand stratum. The global stability safety factor is greater than 1.33. A graphical solution is provided for both the drained and undrained soil conditions and is included in this report as Attachment 2 and Attachment 3, respectively.

\section{GENERAL COMMENTS}

If significant changes are made in the character or location of the proposed project, a consultation should be arranged to review any changes with respect to the prevailing soil conditions. At that time, it may be necessary to submit supplementary recommendations.

All sheeting, shoring, and bracing of trenches, pits and excavations should be made the responsibility of the contractor and should comply with all current and applicable local, state and federal safety codes, regulations and practices, including the Occupational Safety and Health Administration. 


\section{REFERENCES}

Bishop, A.W. 1955. The Use of the Slip Circle in the Stability Analysis of Slopes. Geotechnique Vol. 28 No. 4, pp 395-411.

Bowles, J.E. 1996. Foundation Analysis and Design. $5^{\text {th }}$ Edition. The McGraw-Hill Companies, Inc.

Janbu, N., Bjerrum, L., and Kjaensli, B. 1956. Stability Calculations for Man-Made and Natural Slopes, (in Norwegian). Norwegian Geotechnical Publication No. 16, Oslo.

Rock Engineering and Testing Laboratory, Inc. 2007. Preliminary Geotechnical Analysis for the Proposed Colorado River Jetty Study, Matagorda County, Texas. RETL Report Number G107134, Corpus Christi, Texas.

Turner, Collie \& Braden, Inc., and DMJM-Harris. 2002. Colorado River and Tributaries, Texas, Mouth of the Colorado River Navigation Channel in Matagorda, Texas. Sediment training structure final design report. Prepared by the U.S. Army Corps of Engineers, Contract No. DAC64-02-D-0002, Task Order No. 6.

U.S. Army Corps of Engineers. 1977. Mouth of Colorado River, Texas, Phase I: General design memorandum (Navigation Features). Galveston, TX: U.S. Army Engineer District, Galveston. 


\section{APPENDIX}




\title{
BORING LOCATION PLAN
}

\author{
NO SCALE
}

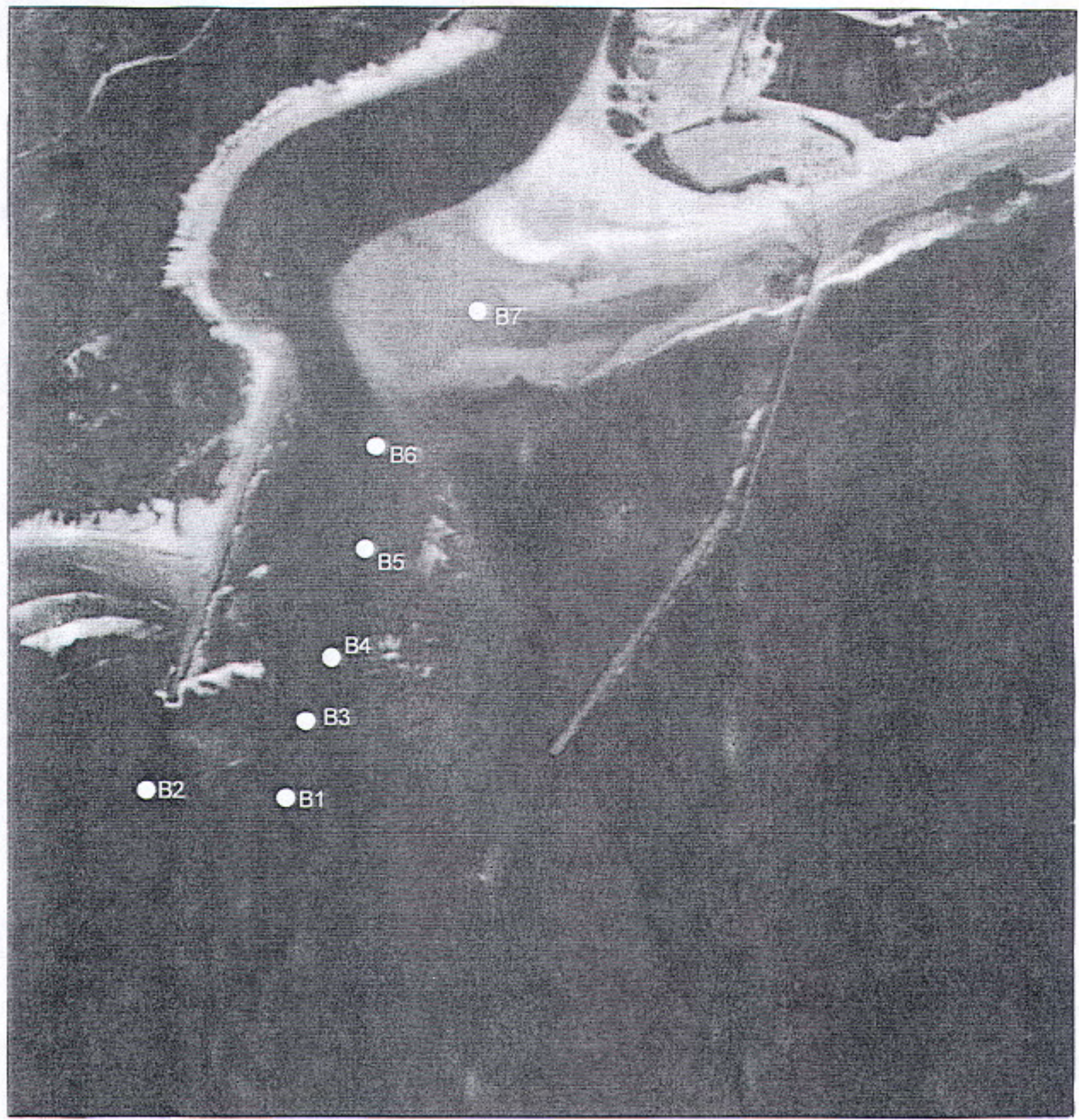

August 20, 2007

NEW EAST JETTY

HDR/Shiner Moseley and Associates, Inc.

RETL Job No. G207487

Mouth of the Colorado River Matagorda, Texas 
LOG OF BORING B-1

SHEET 1 of 1

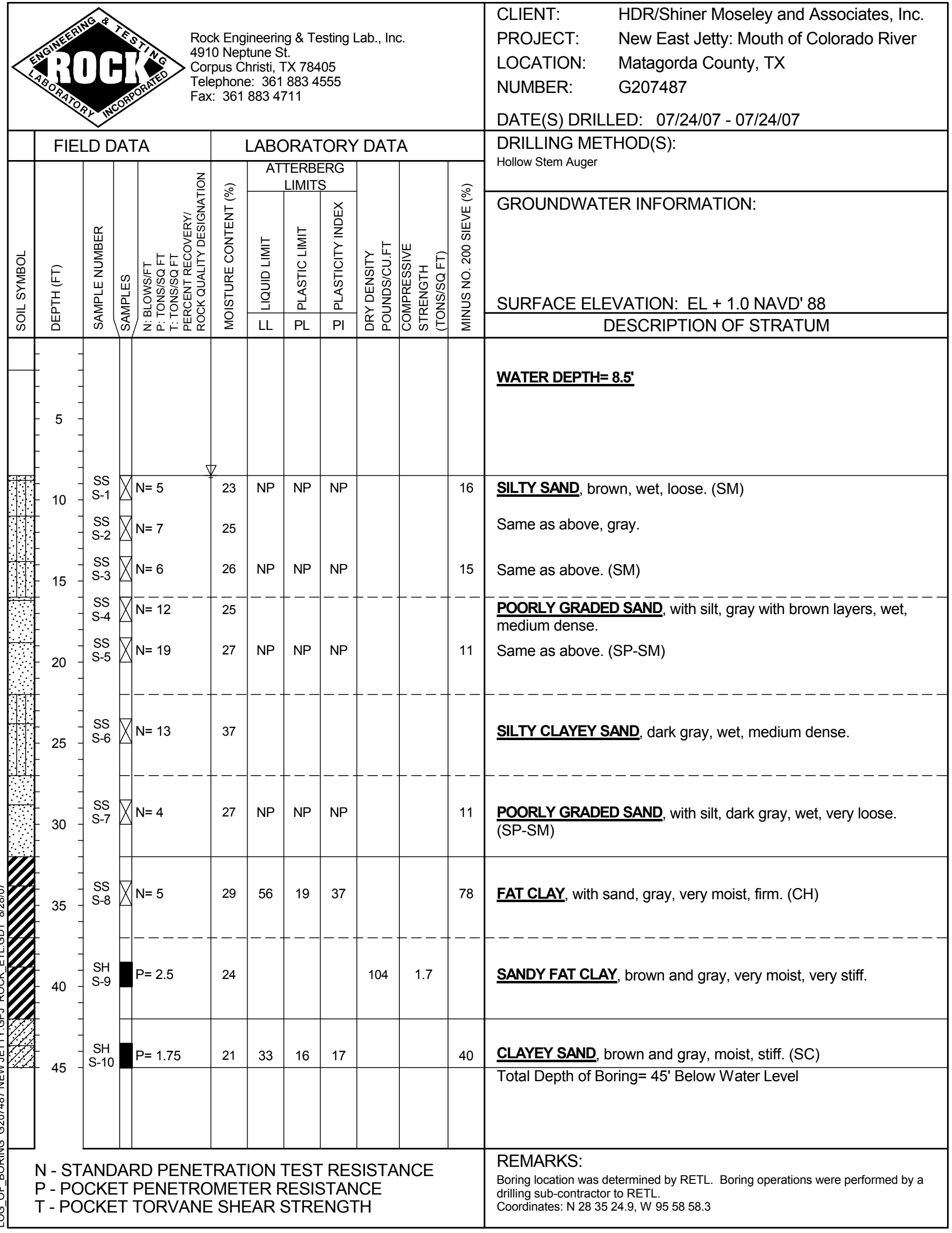


LOG OF BORING B-2

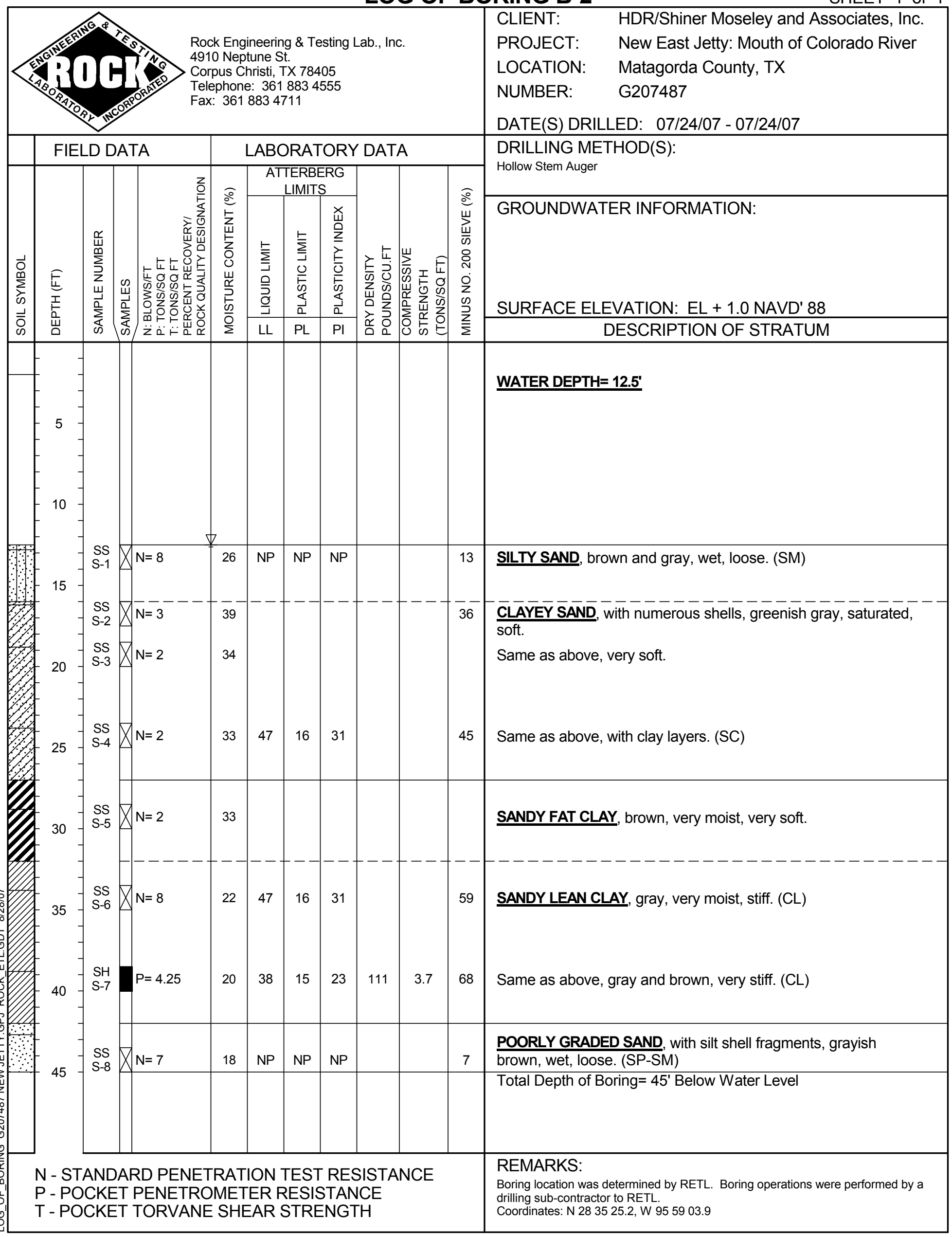


LOG OF BORING B-3

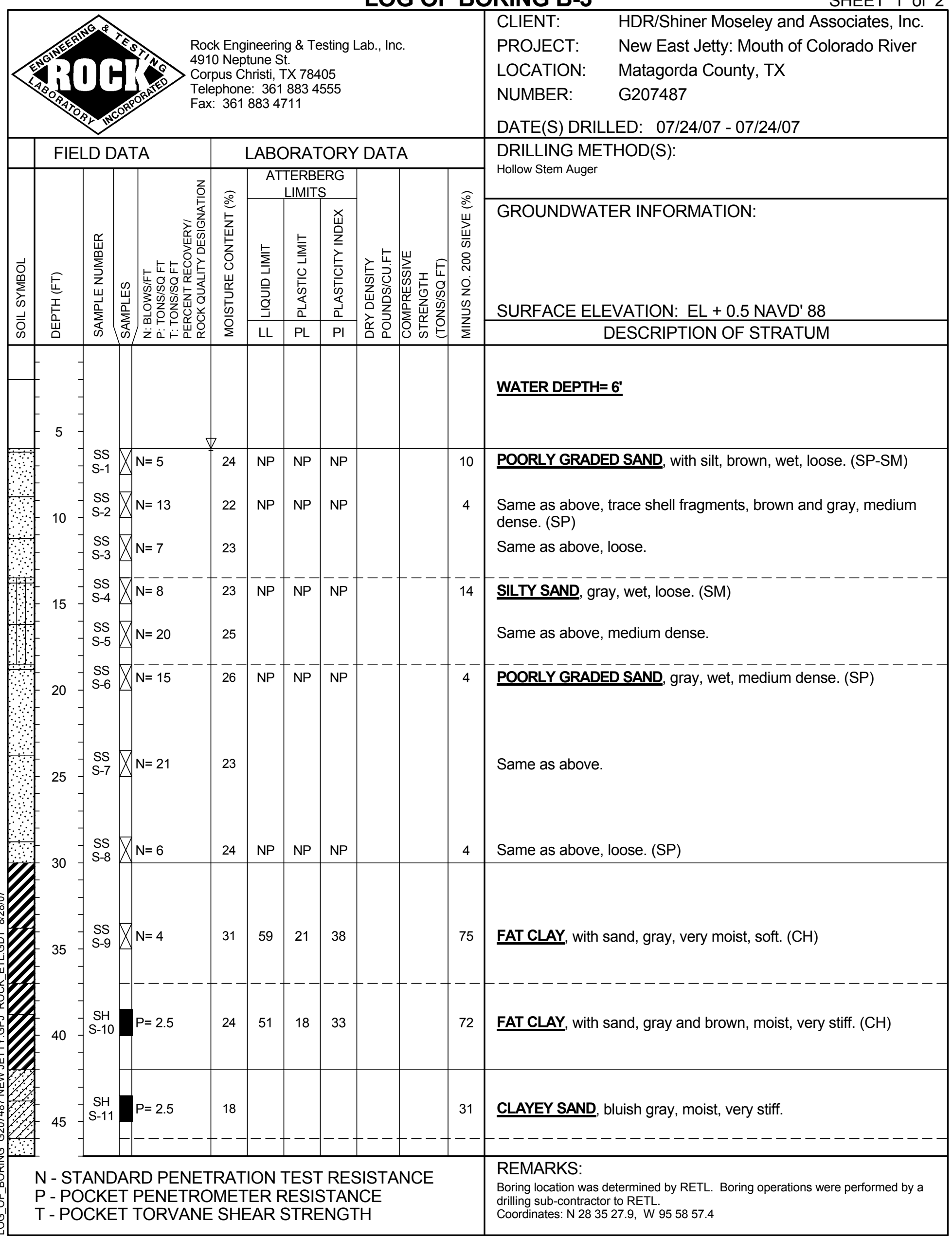


LOG OF BORING B-3

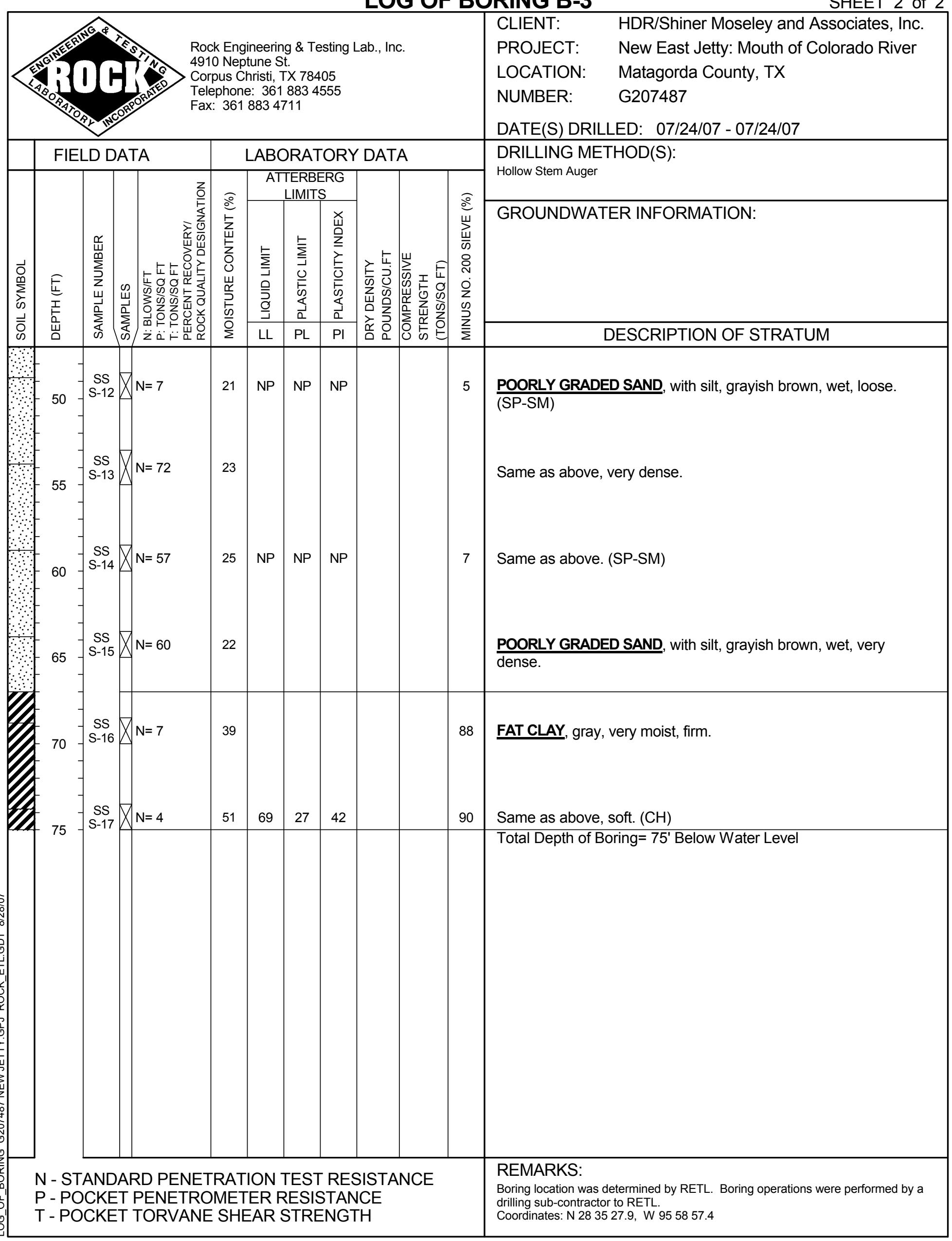


LOG OF BORING B-4

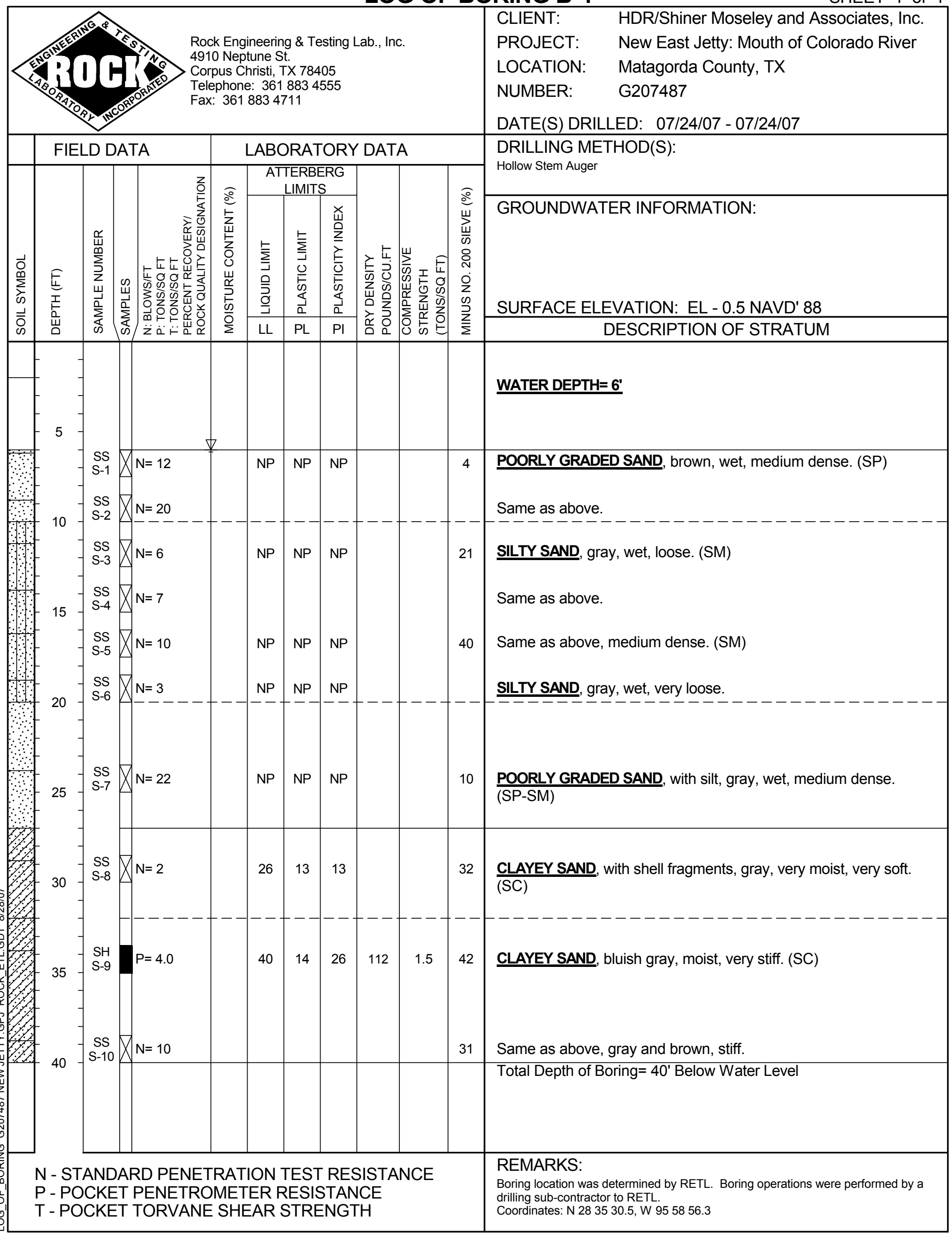


LOG OF BORING B-5

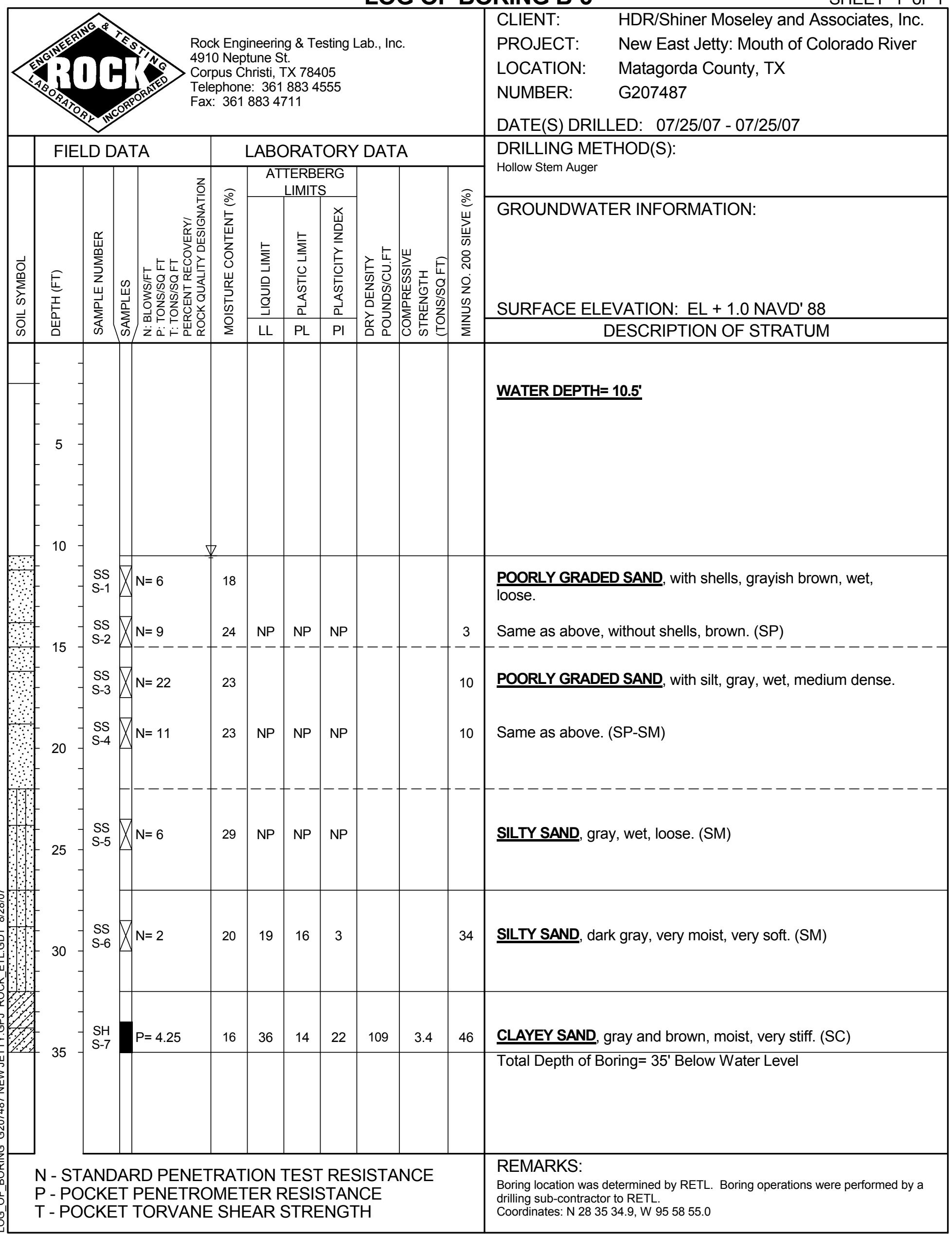


LOG OF BORING B-6

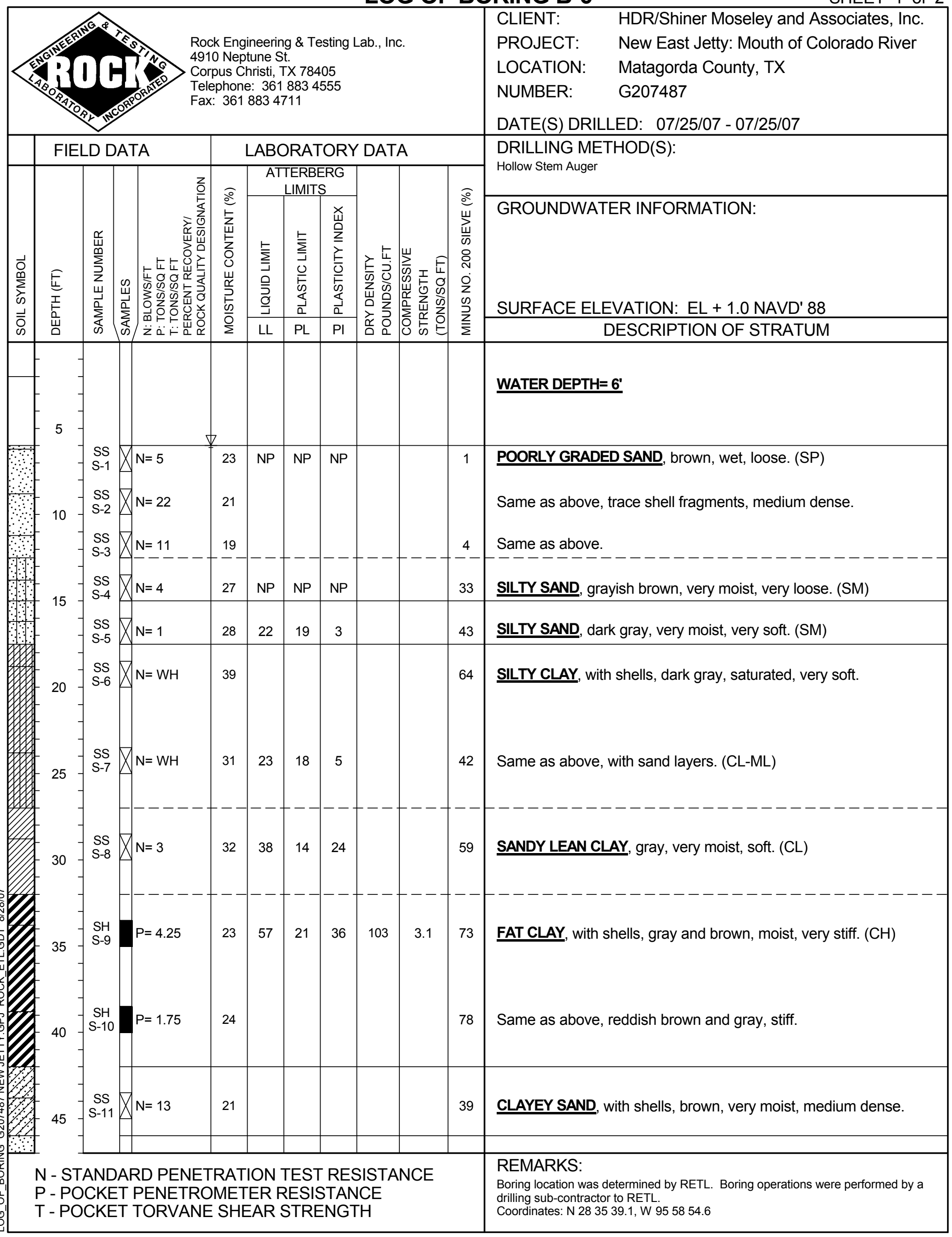


LOG OF BORING B-6

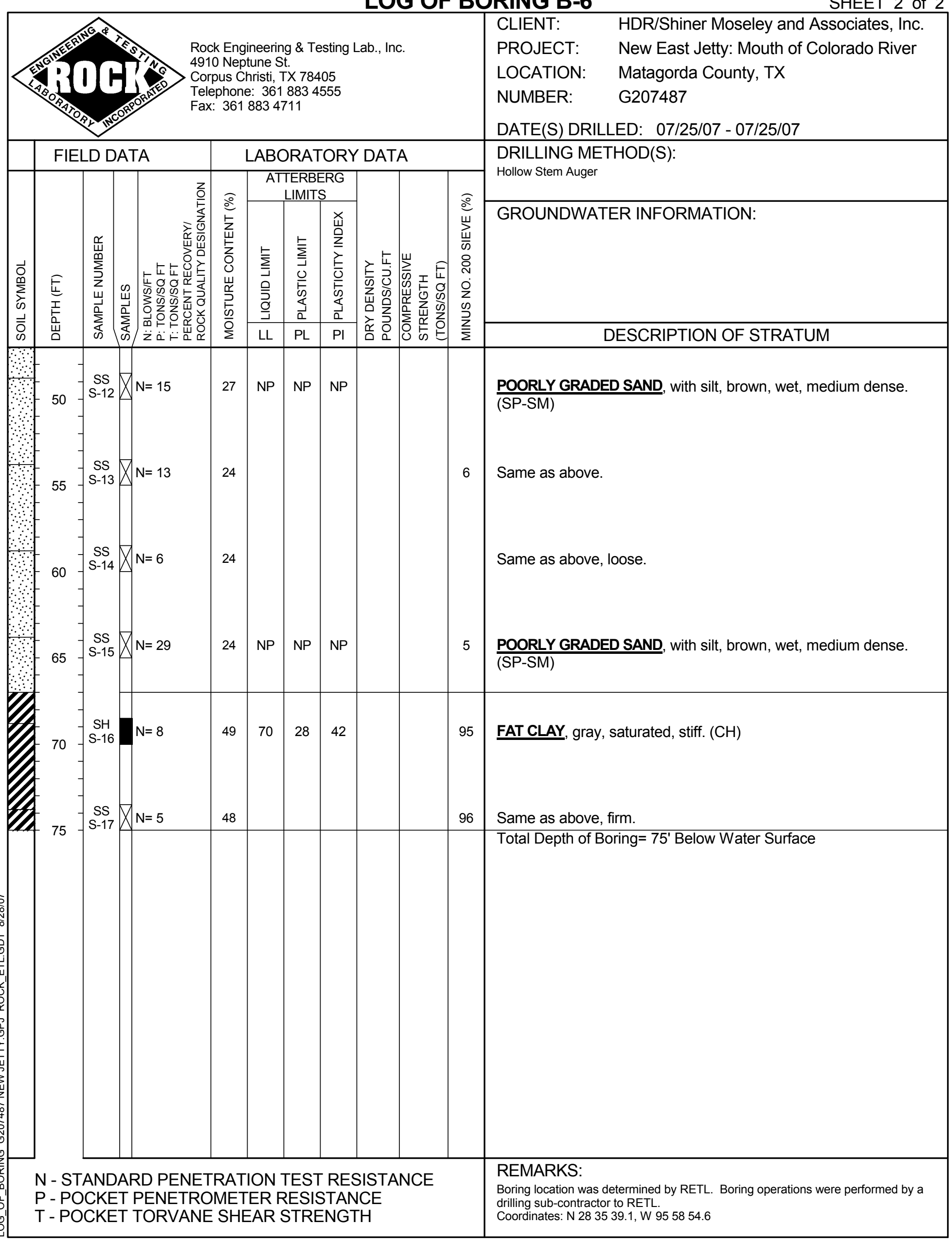


LOG OF BORING B-7

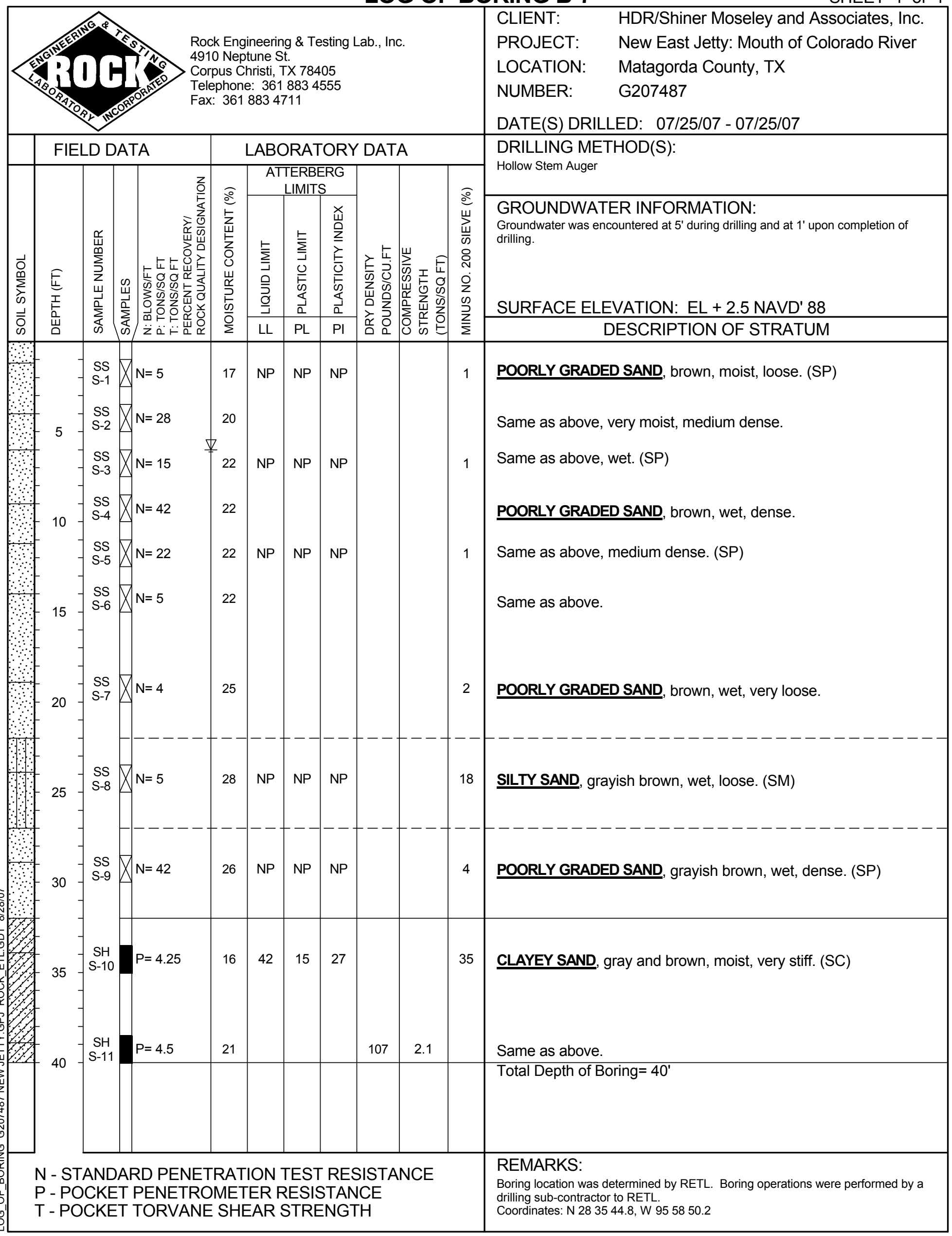




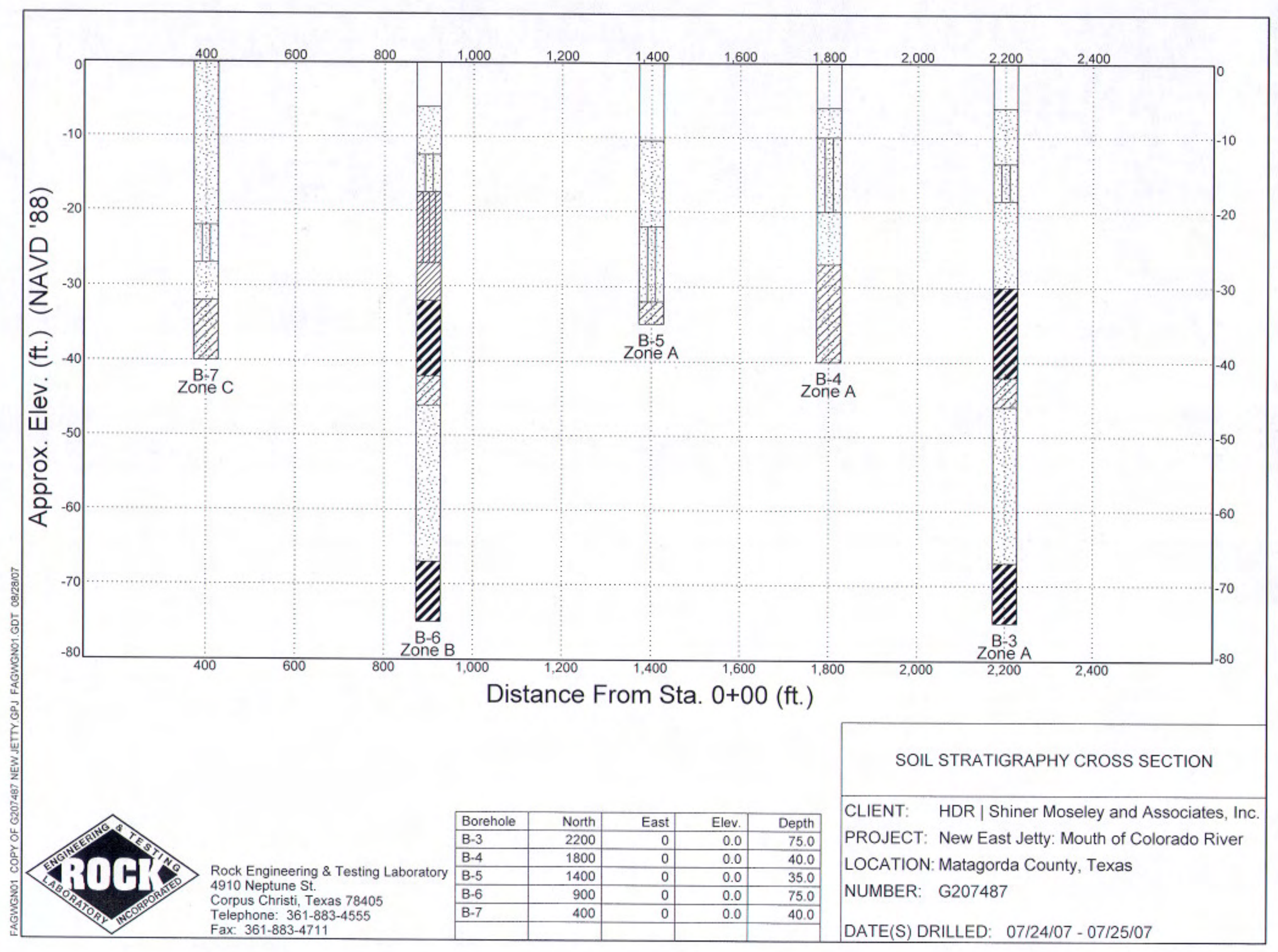




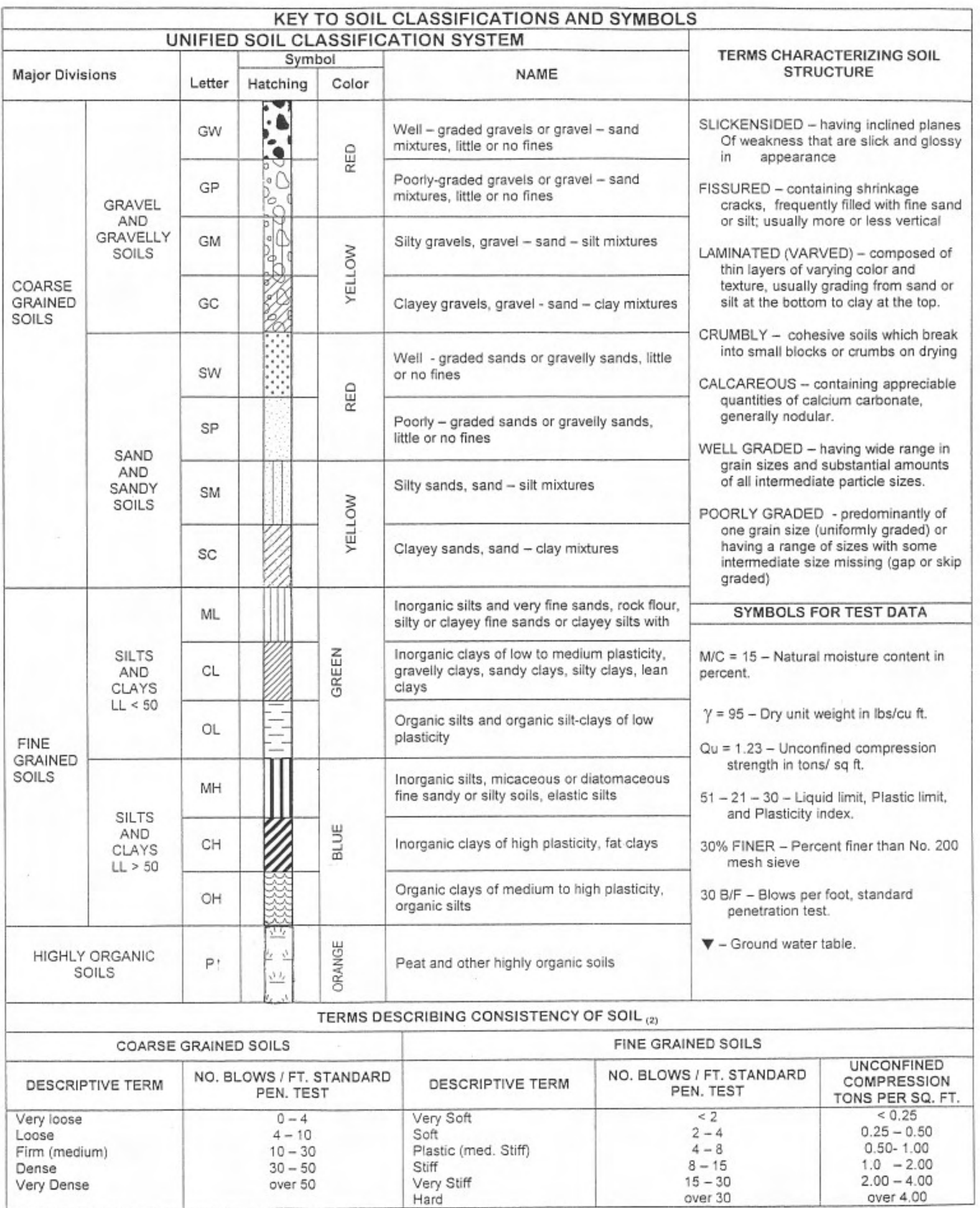

Field classification for "Consistency" is determined with a 0.25 " diameter penetrometer. 


\section{VOID RATIO VERSUS LOG OF PRESSURE \\ BORING B-3 (38.5' - 40')}

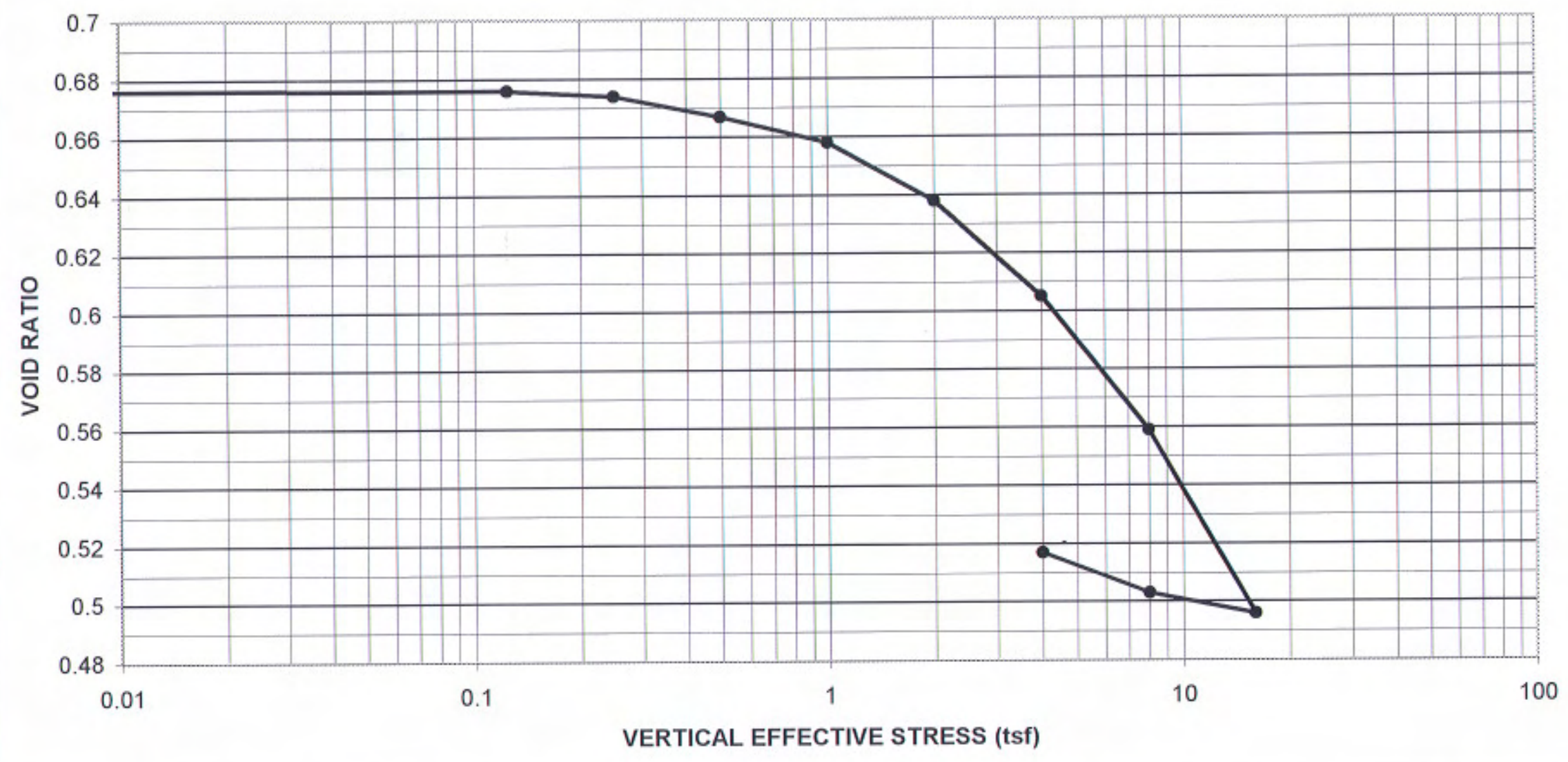

Assumed Specific Gravity

2.70
Initial / FinalVolume (cu in.)

$4.91 / 4.38$ $\underline{\text { Initial / Final Height (in.) }}$ $1.0 / 0.89$
Initial / Final Void Ratio $0.676 / 0.496$

\begin{tabular}{|c|c|c|c|}
\hline DESCRIPTION & PROJECT & DATE TESTED & SAMPLE ID \\
\hline $\begin{array}{c}\text { Gray and Brown Fat Clay } \\
(\mathrm{CH})\end{array}$ & MCR New East Jetty & $08 / 02 / 07$ & B-3 38.5'-40' \\
\hline
\end{tabular}

ROCK ENGINEERING \& TESTING LABORATORY, INC. 


\section{VOID RATIO VERSUS LOG OF PRESSURE \\ BORING B-6 (33.5' - 35')}

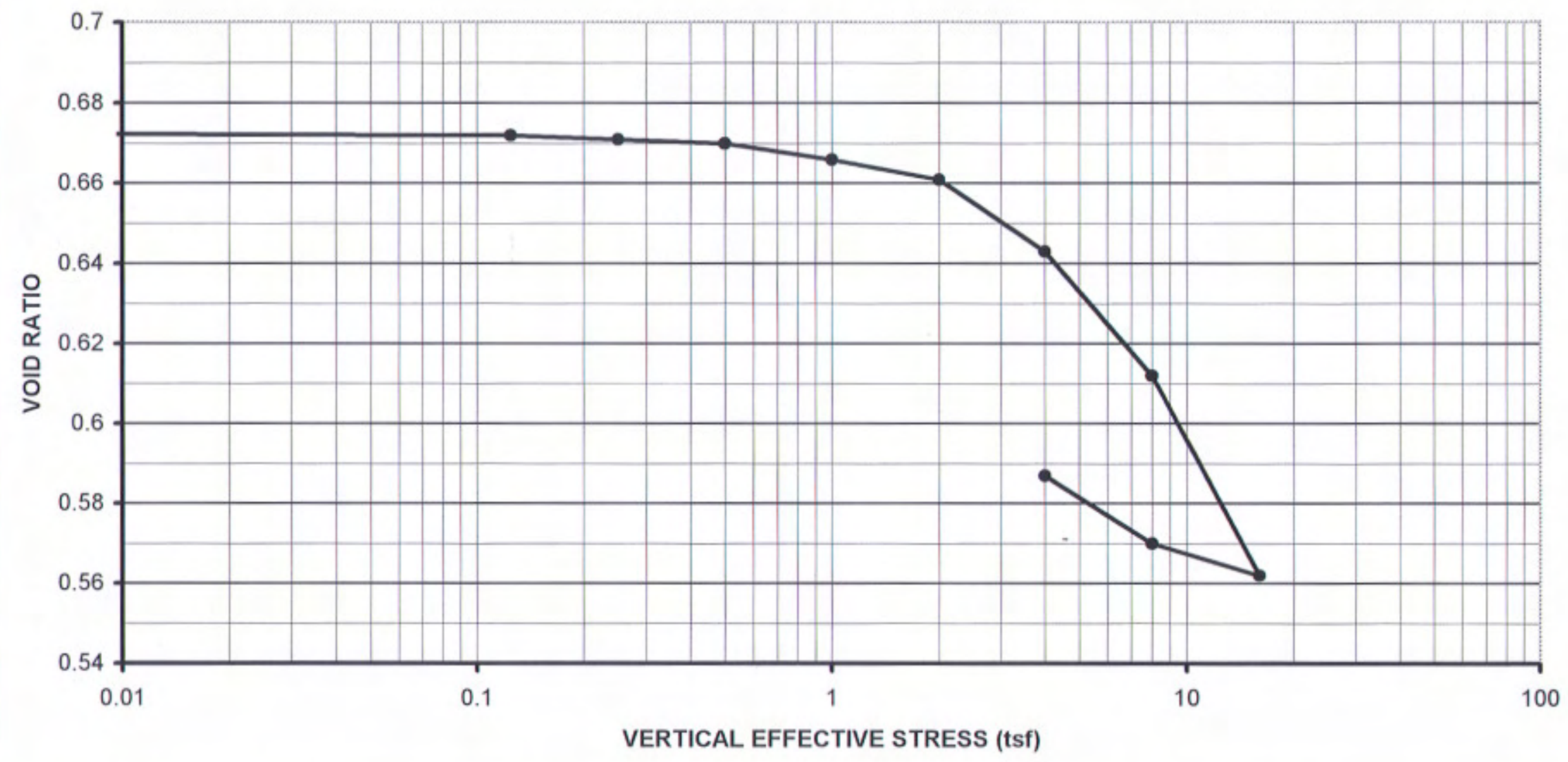

Assumed Specific Gravity 2.70
Initial / FinalVolume (cu in.) $4.91 / 4.58$
Initial / Final Height (in.) $1.0 / 0.93$
Initial / Final Void Ratio $0.672 / 0.562$

\begin{tabular}{|c|c|c|c|c|}
\hline DESCRIPTION & PROJECT & DATE TESTED & SAMPLE ID & PROJECT NO. \\
\hline $\begin{array}{l}\text { Gray and Brown Fat Clay } \\
\qquad(\mathrm{CH})\end{array}$ & MCR New East Jetty & $08 / 02 / 07$ & B-6 33.5'-35' & G207487 \\
\hline
\end{tabular}

\footnotetext{
ROCK ENGINEERING \& TESTING LABORATORY, INC.
} 


\section{ATTACHMENTS}




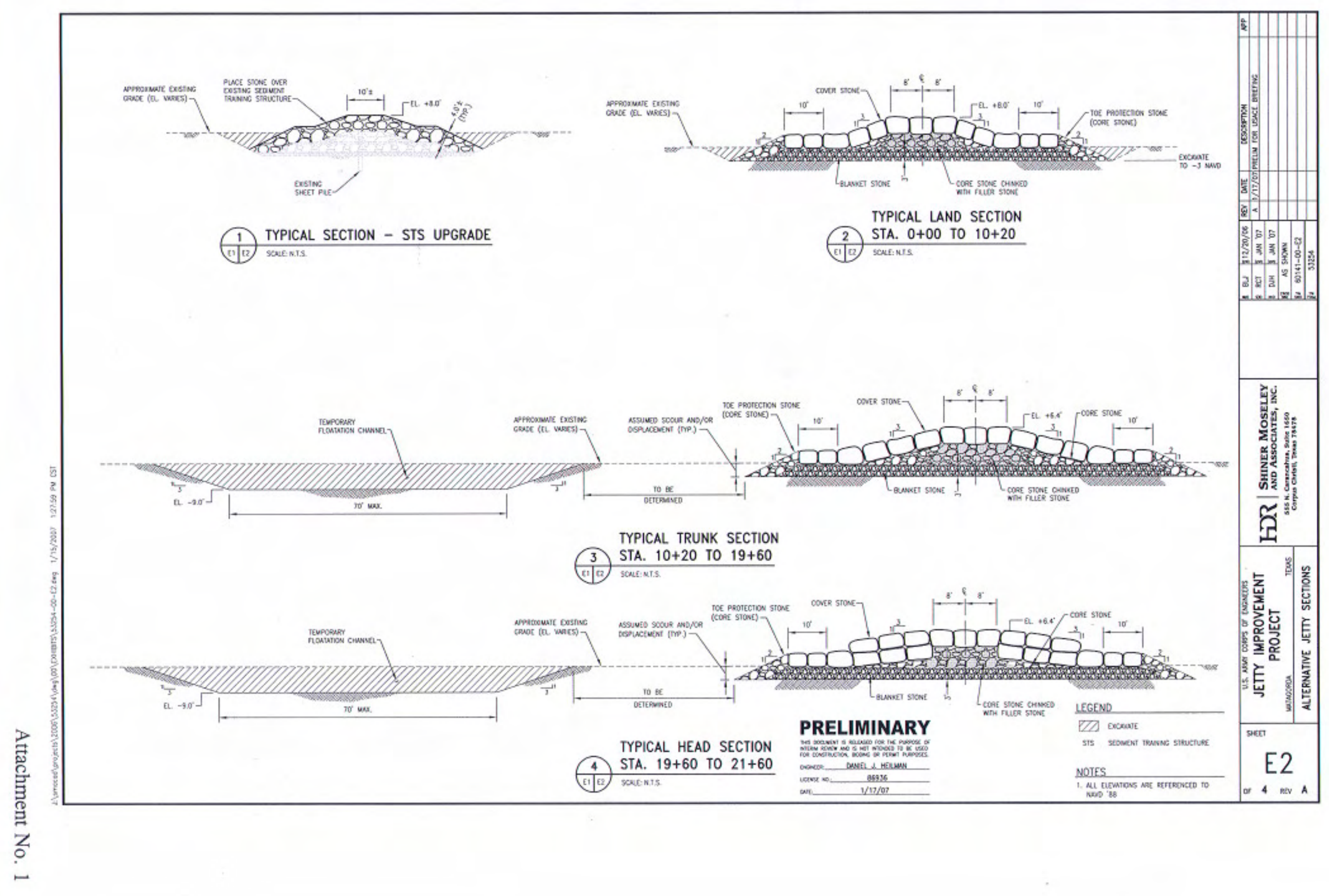




$\begin{array}{llllll} & \begin{array}{l}\text { Gamma } \\ \text { pcf }\end{array} & \text { psf } & \begin{array}{l}\text { Phi } \\ \text { deg }\end{array} & \begin{array}{l}\text { Piezo } \\ \text { Surf. }\end{array} & \text { Ru } \\ \text { Water } & 62.4 & 0 & 0 & 0 & 0 \\ \text { Jetty } & 158.5 & 0 & 0 & 1 & 0 \\ \text { Sand } & 115 & 0 & 28 & 1 & 0 \\ \text { Clay } & 110 & 200 & 17.5 & 1 & 0 \\ \text { Clay } & 120 & 520 & 25 & 1 & 0 \\ \text { Sand } & 120 & 0 & 35 & 1 & 0 \\ \text { Clay } & 115 & 400 & 20 & 1 & 0 \\ \text { Hard Bottom } & \text { (Infinitely Strong) } & & \end{array}$

Rock Engineering and Testing Laboratories G207487 New E. Jetty @ Colorado River 08/28/07

Land Section; Soil Profile for B-6 Drained Values; $10^{\prime}$ Shoulder from toe of slope

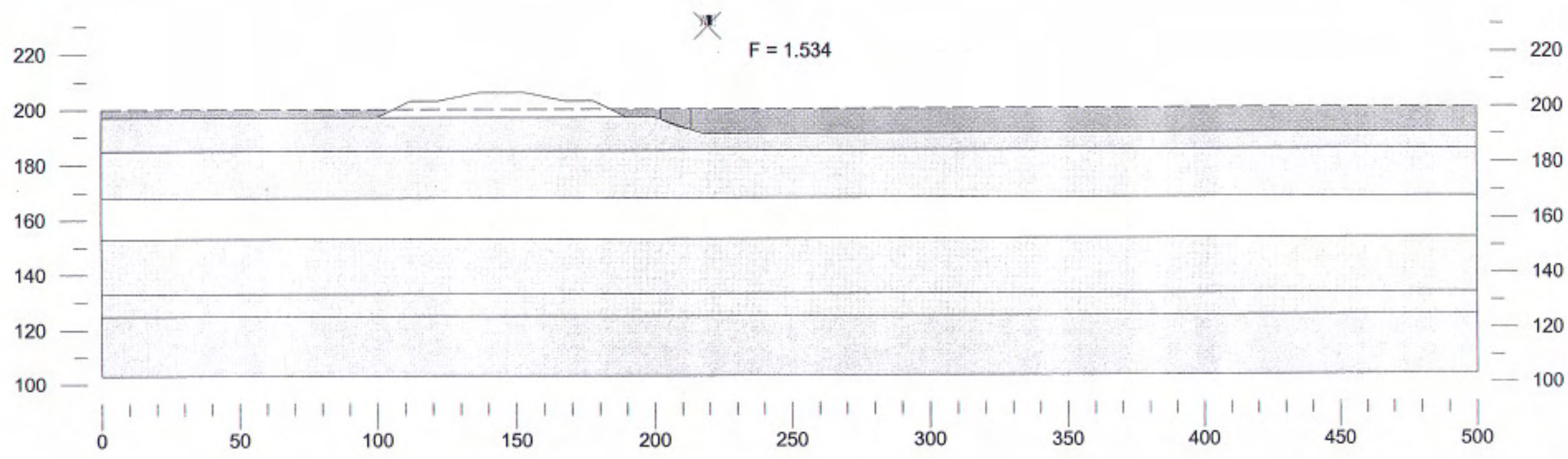

8/28/2007 9:22:12 AM U:IG7134DV.GSL. Rock Engineering and Testing Laboratories $F=1.534$ 


$\begin{array}{llllll} & \begin{array}{l}\text { Gamma } \\ \text { pcf }\end{array} & \text { psf } & \text { Phi } & \text { Pieg } & \text { Surf. } \\ \text { Water } & 62.4 & 0 & 0 & 0 & 0 \\ \text { Jetty } & 158.5 & 0 & 0 & 1 & 0 \\ \text { Sand } & 115 & 0 & 28 & 1 & 0 \\ \text { Clay } & 110 & 250 & 0 & 1 & 0 \\ \text { Clay } & 120 & 2000 & 0 & 1 & 0 \\ \text { Sand } & 120 & 0 & 35 & 1 & 0 \\ \text { Clay } & 115 & 1000 & 0 & 1 & 0 \\ \text { Hard Bottom } & \text { (Infinitely Strong) } & & \end{array}$

Rock Engineering and Testing Laboratories G207487 New E. Jetty@ Colorado River 08/28/07 Land Section; Soil Profile for B-6 Undrained Values; 10' Shoulder from toe of slope

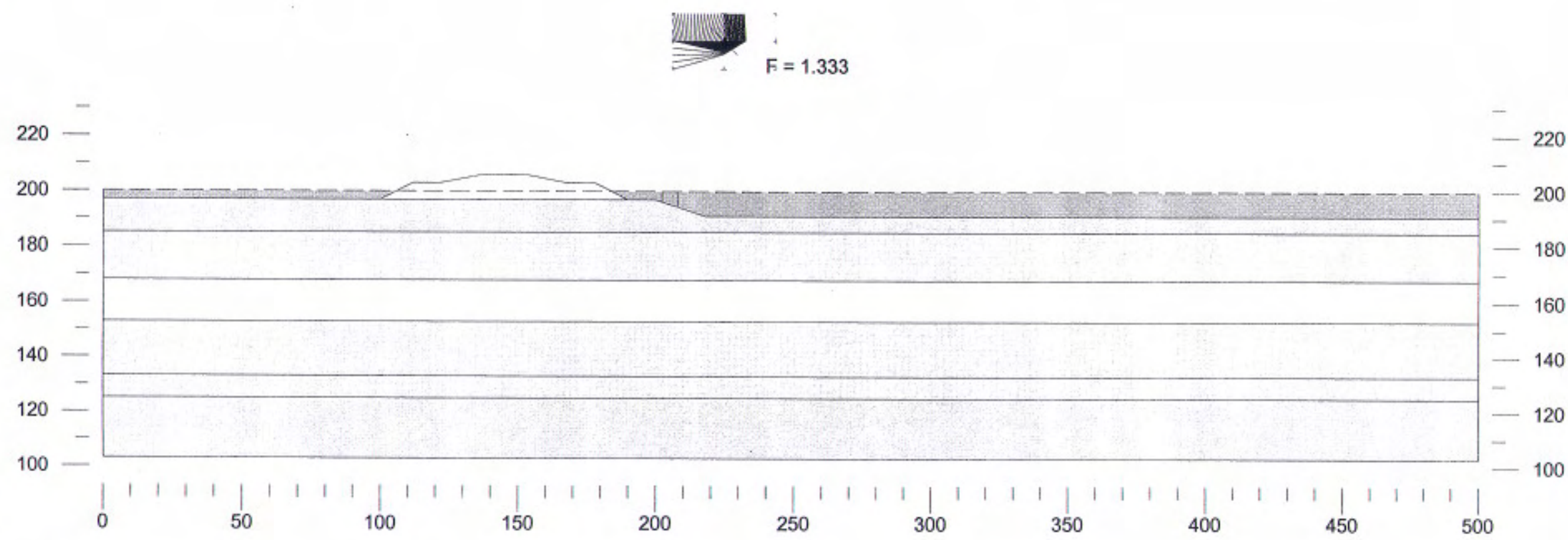

9/28/2007 9:16-50 AM UIG7134DV.GSL. Rock Engineering and Testing Laboralories $F=1.333$

Attachment No. 3 


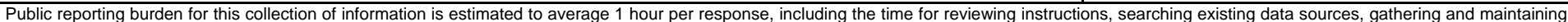

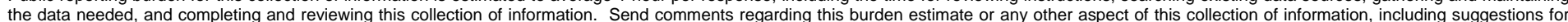

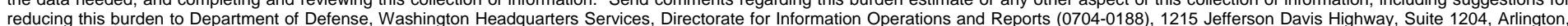

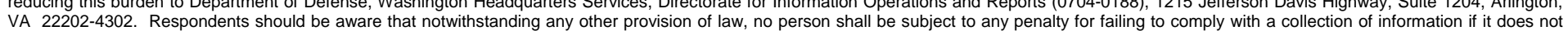
display a currently valid OMB control number. PLEASE DO NOT RETURN YOUR FORM TO THE ABOVE ADDRESS.

\begin{tabular}{l|l}
$\begin{array}{l}\text { 1. REPORT DATE }(D D-M M-Y Y Y Y) \\
\text { April } 2008\end{array}$ & $\begin{array}{c}\text { 2. REPORT TYPE } \\
\text { Final report }\end{array}$ \\
\hline
\end{tabular}

\section{TITLE AND SUBTITLE}

Long-Term Structural Solution for the Mouth of Colorado River Navigation Channel, Texas

3. DATES COVERED (From - To)

5a. CONTRACT NUMBER

5b. GRANT NUMBER

5c. PROGRAM ELEMENT NUMBER

5d. PROJECT NUMBER

5e. TASK NUMBER

5f. WORK UNIT NUMBER

8. PERFORMING ORGANIZATION REPORT NUMBER

ERDC/CHL TR-08-4

U.S. Army Engineer Research and Development Center

Coastal and Hydraulics Laboratory

3909 Halls Ferry Road, Vicksburg, MS 39180-6199;

HDR IShiner Moseley and Associates, Inc.

555 N. Carancahua, Suite 1650, Corpus Christi, TX 78478-0010

9. SPONSORING I MONITORING AGENCY NAME(S) AND ADDRESS(ES)

U.S. Army Engineer District, Galveston

2000 Fort Point Road

Galveston, TX 77550

10. SPONSOR/MONITOR'S ACRONYM(S)

11. SPONSOR/MONITOR'S REPORT NUMBER(S)

\section{DISTRIBUTION / AVAILABILITY STATEMENT}

Approved for public release; distribution is unlimited.

\section{SUPPLEMENTARY NOTES}

\section{ABSTRACT}

This report describes a study performed for the U.S. Army Engineer District, Galveston, to develop a structural solution involving modified or new jetties in support of a reliable shallow-draft channel at the Mouth of the Colorado River (MCR), Texas. The site has experienced excessive sediment shoaling that has denied full project features to navigation channel users. The study took a multidisciplinary approach involving field measurements, shoreline analysis, numerical modeling of shoreline change and longshore sand transport, numerical modeling of inlet processes, and preliminary design of a new east jetty. The study concluded that the MCR was not performing as intended because (1) the Colorado River was diverted to Matagorda Bay in 1992 as part of an environmental restoration project, thus depriving the inlet of the river's discharge of water and associated scouring action; (2) the weir jetty system constructed over 1988-1990 was too wide and the weir section too long; and (3) the sediment impoundment basin associated with the weir is dangerous for people wade fishing and allows sediment to be bypassed during times of high water.

The solution obtained is to construct a new east jetty parallel to and $500 \mathrm{ft}(152 \mathrm{~m})$ from the west jetty. It is recommended that past bypassing practice be continued through dredging of the impoundment fillet expected to form on the beach adjacent to the new east jetty and placing that material on the west beach. The preliminary jetty design incorporates experience with jetties of similar size inlets along the Texas coast.

\section{SUBJECT TERMS}

Coastal inlet

Coastal modeling system

16. SECURITY CLASSIFICATION OF:

\section{a. REPORT}

UNCLASSIFIED
Jetty

Longshore transport

\begin{tabular}{|l|c|}
\hline $\begin{array}{l}\text { 17. LIMITATION } \\
\text { OF ABSTRACT }\end{array}$ & $\begin{array}{c}\text { 18. NUMBER } \\
\text { OF PAGES }\end{array}$ \\
& 187 \\
& \\
\cline { 2 - 2 } &
\end{tabular}

Navigation channel

19a. NAME OF RESPONSIBLE PERSON

19b. TELEPHONE NUMBER (include area code) 